\title{
The Development of a Group Preschool Screening Test of Early School Entrance Potentiality
}

August Edward Ahr

Loyola University Chicago

Follow this and additional works at: https://ecommons.luc.edu/luc_diss

Part of the Education Commons

\section{Recommended Citation}

Ahr, August Edward, "The Development of a Group Preschool Screening Test of Early School Entrance Potentiality" (1936). Dissertations. 788.

https://ecommons.luc.edu/luc_diss/788

This Dissertation is brought to you for free and open access by the Theses and Dissertations at Loyola eCommons. It has been accepted for inclusion in Dissertations by an authorized administrator of Loyola eCommons. For more information, please contact ecommons@luc.edu. (c) (i) $(9)$

This work is licensed under a Creative Commons Attribution-Noncommercial-No Derivative Works 3.0 License. Copyright $\odot 1936$ August Edward Ahr 
THE DEVELOPMENT TF A GROUP PRESCHOOL SCREENING TEST OF

EARLY SCHOOL ENTRANCE POTENTIALITY

by

August Edward Ahr

A D1ssertation Submitted to the Faculty of the Graduate Sohool of Loyola University In Partial Pulfiliment of the Requirements for the Degree of Dootor of Education

January

1966 
Copryight by

Auguet Bdward Ahr

1966

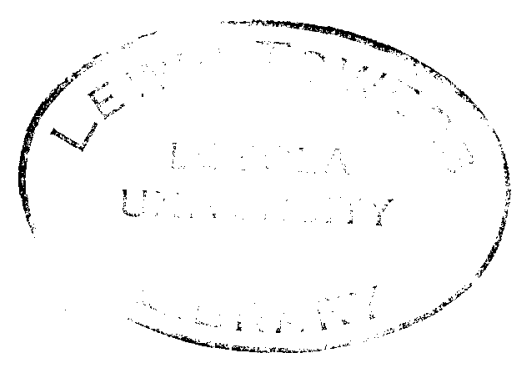




\section{LIFE}

August Edward Ahr was borm January 27, 1936, in Albuquerque, New Mex100, where he oompleted h1s elementary and secondary education at St. Mary's Grade and H1gh School.

He began h1s undergraduate course work at Spring H111 College, Moblle, Alabama, but later transferred to the University of New Mex1co where he was granted the Bachelor of Solence degree In June, 1957, and Master of Science degree in June, 1959.

During 1959 the author taught English and soolal studies at the seventh grade level at Blythe Junior High Sohool, Blythe, California. In 1960, he served the Plattsburgh Public Sohools In upper New York State as a school psyohologist and spent the following two years in the same oapacity with the Cayuga County Publio Schools in central New York State. Since 1962, he has been employed as a sohool psychologlst by the N1les Township Department of Speo1al Eduoation, Linoolnwood, I111no1s. In 1964, he was appointed Supervising Sohool Psyohologist.

H1s Master's thesis was published under the title, "The Role of Error Density and Set in a Vigilance Task", in the Journal of Applied Psycholosr, XIIV (Apr11, 1960), 205-209. The author has published two other artioles: "The Psychological Referral: A Procedural Approach", Psychology in the Schools, II (July, 1965) 224-228; and coauthored "The School Psychologist as a Resouroe Person: Inltiating and Conducting In-service Teacher Education", 
Pstchology in the Schools, II, (July, 1965), 220-224.

The writer holds membership in the Amerioan Psychological Association and the IIlinols Psychological Association. 


\section{ACKNOWIEDGMENTS}

The author wishes to express his gratitude to nembers of Loyola's Education Department for the encouragement and assistance they extended; partioularly to Dr. Samuel T. Mayo and Dr. John M. Wozniak. Personal thanks to Mr. Wesley Gibbs, Superintendent of Sohool Distrlot 68, Skokle, Illinols, who allowed the use of his sohool faollities and resources so the present study could be oompleted, and Dr. Glen Thompson, Director of Besearoh in Distriot 68 , for his guldance and helprul suggestions In the statistical treatment of the data. A very special tribute is due to my wife, Marjorte, for her patient understanding, oontinued inspiration and inventiveness and artist1o ab111ty displayed in the preparation of outline drawing which served as test Items in the development of the group preschool instrument. Lastiy, a sincere expression of thanks to my three ohildren, (Kristina, Edward, and Amy) who allowed their father to use most of his spare time pursuing his education and a solemn promise to rectify this state of affairs. 
TABLE OF CONTEMPS

CHAPTER

PACE

I. INTRODUCTION . . . . . . . . . . . . . . . 1

Statement of the Problem ............ 8

Purpose or the Study . . . . . . . . . . . 9

S1entricance of the Problen . . . . . . . . . 9

Scope of the study . . . . . . . . . . . . 11

Questions to be Answered .............. 11

Sumary. . . . . . . . . . . . . . . . 12

II. HEVIEW OF THE LITERATURE . . . . . . . . . . 14

Present Adm1ssion Pollo1es in the Untted States . . 14

Multiple Criterla for Sohool Readiness . . . . . 15

Chronological age ............. 16

Mental age ................. 19

Social and omotional maturity .......... 21

Physloal maturity . . . . . . . . . . . 22

Sex ...................... 22

Practical Problems of Eariy Admission . . . . . 24

D1striots Dissatisfled with Flexible Admission

Prograns ........................ 27

Desoription and Evaluetion of Early Entrance Programs 30 Evanaton, I111nols............ 30 Brookline, Massachusetts . . . . . . . . 32 Minneapol18, Minnesota............ 36 
PAGE

Nobraska . . . . . . . . . . . 39

Pennsyltan1a . . . . . . . . . . . . . 42

Underage High School and College Students . ... 44 Suggested Guldelines for Early Entrance Programs . 46

Chronological age .............. 47

Mental age .................. 47

Parontal request . . . . . . . . . . 49

Physloal health . . . . . . . . . . 49

Soolal and emotional maturity ........ 50

Physioal size and coordination ........ 50

Sex ................... 50

Reporting the decision ........... 50

Parent interview ............... 51

Retesting . . . . . . . . . . . . 51

standardized toats............. 52

Dec1sion . . . . . . . . . . . . . 52

Trial period . . . . . . . . . . . . 52

Present Tests Araliable at the Preschool Level . . 53

Test1ng Problems at the Presohool Level . . . . 54

Group Pesting and the Preschool Lerel . . . . 56 .

III. DESIGN . . . . . . . . . . . . . . . 59

Bationalo . . . . . . . . . . . . 59

Item Seleotion .............. 63

Test Materials................. 72 
IV. METROD ........................ . . 77

The Sample . . . . . . . . . . . . . . 77

Coneral Prooddures ......... . . . . . . 80

Group Teet Prooodures ............... 82

v. hesulms ....................... 88

Group Test Hornat2ve Data . . . . . . . . 88

Rapport and Motivation ............... 98

Sultability of Tost Items . . . . . . . . . 99

Rollabl11t5 ...........................

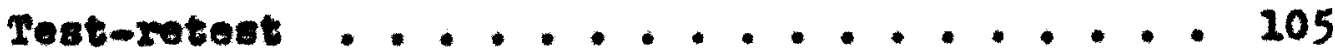

Kuder - Miohardeon est1mates . . . . . . . 108

Hort's analyals of vartance.......... 108

Val1a1ty ....................... 108

Pace rallalty .. . . . . . . . . . . . 108

Conourrent valialty ............. 109

Erriolenor and Efreotiveness . . . . . . . 120

Profesalonal Personnel T1we and Exponse . . . . 116

Specialist's rime . . . . . . . . . . 116

Seorer rellabil1t5. . . . . . . . . . . 116

Speciallat"a expense . . . . . . . . . . 118

Cons1deration of Queations . . . . . . . . . 119

VI. DIScussion, COMGLUSIONS, AND RECOMMENDATIONS . . . 121

Group Teat Nomative Data ............ 121

Rapport and Kot17ation .............. 124

Sultabl11ty of Teat Itens . . . . . . . . . 126 
v111

PAGE

Rellab111ty . . . . . . . . . . . . 128

Valldity .................. 134

Efflolenoy and Efreotiveness .......... 138

Professional Personnel T1me and Expense . . . . 141

Conclusions . . . . . . . . . . . . 142

Reoommendat1ons .............. 146

viI. SUMMARI ..................... 150

BIBLIOGRAPHY . . . . . . . . . . . . . . 154

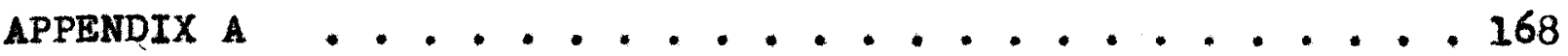

APPENDIX B . . . . . . . . . . . . . . . . . . 200

APPENDIX C . . . . . . . . . . . . . . . . 258 


\section{LIST OF TABLES}

TABID

PAGE

I. Achlevement of Early Entrance Puplls at End of Thisd Grade, Predioted from Preschool Blnet

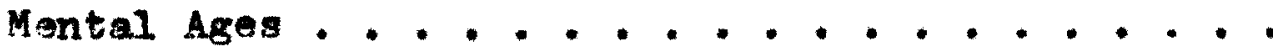

II. Item Anelysis Data on Stanford-Binet Comparing Presohoolers who were Admitted Early and Rejeoted for Kindergarten Placement

III. Frequency Distributions of Item Analys1s Data for Disorimination and Difficulty Indexes on Fifty Try-out Items in Original Group Test with Nursery Sohool Children . . . . . . . . . . . . .

IV. Type and Number of Items Included in Preschool Group rest

v. Stze of Sample by Blrthdate and Sex . . . . . . . 80

VI. Comparison of Group and Individual Test Hesults . .

VII. Frequency DIstributions of hax Soores for eaoh Age Group in sample . . . . . . . . . . . .

VIII. D1frerence between Means by Age.......... . 93

IX. Frequeney Diatributions of Raw Soores by Sex . . . 94

$X$. Deriation Intelligenoe Quotients for Group Test Normative Sampl

XI. Constants utilized in Formule to obtain Deviation IQ's for Nomative Sample . . . . . . . . . . 
XII. Iten AnsIJs1s Data for Group Presohool Scroening

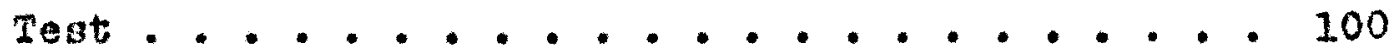

XIII. Frequency Distributions of Iten Analysis Data for Discrimination and Difriculty Indexes . . . . . 102 XIV. Rellab111ty Estimates for Upper and Lower TwentySeven Peroent of Sample . . . . . . . . . 103

XV. Group Test Items Demonstrating a Bias in faror or Girls

XVI. Sumary of Studies on Test-Retest Rellab111ty . . 105 XVII. Test-Retest Raw Data for Four Week Interval in Adninistration of Group Test . . . . . . . . 106

XVIII. Test-Retest Raw Data for Elght Week Interval in Adninistration of Group Test . . . . . . . . 107

XIX. Prequency D1stributions of Group and Indiridual Intelligence scores . . . . . . . . . . . 111

XX. Bivariate D1stribution showing Relationship bebween Test Scores on Group Test and Individual Test . . 113 XXI. Expectanoy Table showing Relation between Early Entrance to KIndergarten Test and stanford-Binet.

XXII. Efflolenoy and Effeotiveness of Group Test by various Cut-off Soores in Sample... . . . . 115 XXIII. Scorer Rellabli1ty Interoorrelations . . . . . . 117 XXIV. Personnel Expend1tures for Early Admission Program 118 


\section{LIST OF FIGURES}

FIGURE

1. Scattergram showing Relationship between Soores on Early Entrance to Kindergarten Screening Test and stanford-Binet ............... 112

2. Rerision of Iten 16 .............. 129

\section{LIST OF PIATES}

Plate

1. Photographs of Administration and Aotivity Period 
CHAPTER I

\section{INTRODUCTION}

Allowing a ohlld to enter sohool earlier than the minimum chronological age requirement on the basis of mult1ple criteria, 1s on of many types of acoeleration arallable to the sohool adminlstrator. Generally, all forms of acceleration are subsumed under two main olassiflcations: rapid progress and double promotion. Rapid progress refers to the opportunity of pup11s to acoomplish thelr regular work at faster rates than arerage. Some examples would Inolude the ungraded primary, ungraded olesses, the lengthened year, or any procedure whioh concentrates instruotion into shorter time periods. Double promotion refers to skipping a grade and may be differentiated from the fomer method in that verifioation 1s generally laoking as to whether the instructional material has been mastered. In fact, in the past grade skipping has been thought to be symonymous with the term acceleration since It was the most comonis used form, and recelved considerable oriticism due to the possible resultant lack of oontinulty of content or gaps in instruotion assoolated with Inadequate planning, The prevaling unfarorable oplnion of acoeleration 18 most unfortunate and contrary to researoh eridence.

After reviowing the ilterature on aoceleration, Gallagher made the following statement: "It 18 very diffloult to find any 
sturit mich has reported, on ba?snoe, any negatlve effeots of acceleration when the acosleration 1 s done as part of a blanned program and is $11 \mathrm{mited}$ to reduoing the students' total eduoational orogram one or two roars."I

Terman and Oden placed some constructive limitations on the feasibility of acceleration gleaned from their longltudinal studies regarding gitted inditiduals. "It is our opinion that nearly all chlldren of 135 Ia or hlghar should be promoted sufficlentiy to peralt college entrance by the age of 17 at least, and that the majority of this group would be better off entering at 16. Acoeleration of this extent is especially desirable for those who plan to complete two or nore jears of graduate study in preparation for a professional arreer."2 A simllar statement was made by Anderson concerning academioally talented students. "It is probable that acceleration should not take place with youngsters whose IQ 18 below 130."3 Pinis refers to approximately the top five percent of all school chlldren in ab1lity.

Let us explore sone of the reasons pointing to the desir-

${ }^{1}$ James J. Gallagher, Analys1s of Research on the Education of Gifted Chlidren (Springfield, III.: - office of Superintendent of Instruction, 1960), p. 113 .

${ }^{2}$ Louls M. Termen and Mellota H. Oden, Genetio Studies of Genius, Volume 4, "The Gifted Child Grows Up" TPalo Alto, Cal1 Stanford University Press, 1947), p. 448.

3. E. Aaderson (Ed.), Besearch on the Academically Talented student (Washington, D.C.: National Education Association, 
ability of aooeleration. The most obvious is that at least no year of the pupil's I1fe is saved. Regardless if no other educational provisions are made (it is hoped this would not be the case), this in itself is quite an achlovement. The trend today 1s the extension of sohooling at higher levels due to the knowledge exploston and teohnologloal advances. The need to nurture and conserve the human resources of our nation has beoone inoreasingly apparent in our post-sputnik era. The demand for high level talent in all technical and professional positions in our oomplex society oontinues at a rapid paoe. Woroester caloulates the values of timesaving in educetion in an interesting manner. "Iet us assume that there are $34,000,000$ school ch1ldren in the United States. Ten per cent of these should, according to our eridence, be able to save year of time. But assume that only three per cent of them could save a gear each. Then our country rould have gained for 1t use more than $1,000,000$ years of 1 ts best brains in a single generation." 4 Reducing the extended sohool experienoe in selected cases is not only of beneflt to soolety but liberates the Individual to follow his own chosen pursults at an earlier age.

Acceleration not only gives proper reoognition to our vast knowledge of indiridual differenoes but implements it in a meaningful may. Just as forcing a child who is not ready to attempt to master material whloh is presently beyond him quite 11kely

\footnotetext{
4D. A. Worcester, The Edueation of Ch1]dren of Above Average Mentailty (Linooin: UnIversity of Nebraska), I956h 0.34 .
} 
1eads to fallure and essoclated unfarorable attitudes, asking a ohlld to walt for the masses may promote careless work hablts, questionable motivation, or unfarorable attltudes toward sohool. If acceleration does nothing more, it places a ohild into a sroup more equal to h1a abli1ty.

Iohman found that the most outstanding oreative work tends to occur early in the careers of famous solentists, Inventors, authors, artists, and mustolans. 5 Pressey observes that in some countries students reoelve the1r dootorate up to four jears earl1er than in the United States and refleots that this may have been a faotor in German solentifio produotivity during the last war. 6 If the greatest physioal rigor, onthusiasn, and intelleotual creativity oome in the early adult years, it rould seem most des1rable to reduoe the individual's eduoation to allow maximum produotivity.

Extended periods of training strongly suggest the possibility of continued dependenoe and delay of adult atatus for supprior studenta. Yet, Terman Indicates that acole rated students marrted and ralsed fam111es at younger ages than non-accelerated

5H. C. Lehman, Age and Achierement, (Prinoetion, N.J.: Prinoeton Unitersity Press, 1953), p. 358.

6sidney L. Pressey, "Bduoat1onal Aoceleration: 0coasional Procedure or Major Issue". Personnel and Guldenoe I., XLI (September, 1962), pp. 12-17. 
pup1ls in h1s follow-up studies. 7 Reynolds polnts out that personal problems and saorifices "are deterrents and delaying factors In higher education." 8 Acoeleration allows the bright student to reduce the amount of tine spent in sohool and to assume h1s independent role as an adult earlier.

As Aressey has sald, "A medical advance would recelve great acclain if it added two jears to one's 1ife, yet an education procedure which accomplishes relatively the same end result 18 disregarded." 9 Some form of acceleration for the mentally adranced chlld allows that same Individual, as an adult, to enter his profession a jear earlier without further delay to independent 11ving.

Thompson and Meyer extans1vely reviewed many previous studies on acoeleration and indioated the researoh evidenoe shows no adverse effeots from acoeleration, although some of the studies had certain 1imltations due to laok of oontrol sroupa, poor presentation of data, or lack of teats of signifleance. Overwhelmine orldence, however, remalns in ravor of acoeleration with positive

\section{Terman and Oden, IV, op. ott., p. 448.}

8 Maynard C. Reynolds, Early school Adm $18810 n$ for Mentally Advanced Chlidren, (Washington, D.C. The Counc11 of Exoeptional ChIIdren, National Education Assoolation, 1962), p. 4

9pressey, op. olt., p. 12. 
effects if it is implemented through careful study and adequate planning. 10

The advantages of acceleration appear to reside in the opportunities which are offered to the individual to proceed at h1s own rate, to meet tasks commensurate with one's ab111ty, to oomplete school earlier, to enter a career earlier, to arold delay of adult status, and to arold possible soc1al and emotional maladjustments and underaohlevement due to nonchallenglng olasses or the development of unfarorable attitudes in suoh olasses.

The following paragraph summarizes some of the disadvantages of acoeleration. Reducing the time spent in sohool may deny bright students the opportunity to think, refleot, explore, and appreolate whioh in turn oould ourtall oreatirity. Equal acceleration in all areas does not take into acoount differences in rates of maturation. Students of like mental ages but varying chronologloal ages may perform qualitatively quite differently. Double promotion may result in serlous instructional gaps in student learning whioh may afrect later eduoational attainments.

It 1 s apparent that not all types of acoeleration can do all things for all students. To use acoeleration effectively and efflolently it is probably essent1al to use that type of

$10 \mathrm{~J}$. Thompson and L. H. Meyer, "What Research Says About Acoeleration," J. Seo. Eduo., XXXVI (May, 1961), pp. 301-305. 
acceleration which oromises to meet the individual needs of each glfted student. This is, Indeed, a diffloult task for mass eduoation. However, the evidence provided by researoh seems to overwhelmingly indicate that the princlple of goceleration Itself is a salutary one.

Early admission to kindergarten is a special form or acceleration for academically talented or glfted youngsters based on variable age admission standards. It combines the major lieas behind acoeleration through rapid progress of subject matter and double promotion by oroviding continulty of education plus enablIng the chlld to oomplete sohool, at least one year earlier.

Early admission adrocates the employment of multiple oriteria for sohool entranoe rather than the erolusive use of the chronological age index. This results in the establishment of plexible admisision requirements that recognize the existence of individual differences and provides for them in realistio manner in the Initial and most crucial phase of formal eduoation.

From the previous abreviated disoussion on that research has to say about acoeleration, 1 t wold seom that early admission retains all of the advantages olted for other forms of acceleration yet reduces some of the disadvantages. Instruotional gaps resulting from 11l-olanned grade skipoing are eliminated. Since the time (one year) is saved prior to beginning formal oducation, length of schooling can remain the same, allowing for depth and 
breadth of leaming experienoss. In addtion, other currtoular mothods of working with wentally able puplls, suoh as, onmohment and special olasees, oould be used in an integrated approaon of the total sohool in meeting the needs of these joungsters.

\section{STATSMENT OF THE PROBLEM}

The present atudy is oonoemed with the soreening and Identification of presohool youngsters for early adilsaion to lindergarten. Typloally, ohlidron onrolled in elementary sohool are sereoned in texms of thelr abll1ty and performanoe on the bas18 of group stendardized tests, grades, and toaoher observation On the basis of this prolininary sereening, lentirioation and seleotion of coadenioally talonted or Glfted onlidren is detexIned through subaequent evaluation, nawely, Individual testing and Interviewing.

At the presohool level soreening inforwation in the usual form of teacher observation, Grades, or group tests is unavallable. Whout the benefit of suoh preliminary data, it is oustowary to notify parents of the potential early entranoe to kindergarten landidate and allow the parents to funotion in a soreening role through their deolsion to reglater thelr ohild for onsideration In the prograx. Indifidual oraluations, then, wust bo given on a wholesale basis to erexy onlld who 18 referred by his parents.

Sohools interested in orerooming the efrects of migla ohronological age requirenents to kindergarten, as one way of ad- 
justing sohool programing to reoognized individual difremenoss at the initial and most oruolal phase of formal eduoation, axe plagued by considerable expenditure. This rinanolal outlay stems from the necessity of providing professlonal personnel and resources for time-oonsuming, Individual evaluations and/or interriews for all early ontrance oandidates. Some means is needed that can serve as a preilminary screening device and limit individual evaluations for the most 11kely oandidates, thereby defraying the total expense of the progran yet ylelding simliar results.

PURPOSE OP THE STUDY

The present study is conoemed with the development, onstruotion, and standardization of a group preschool soreening test for early admission to kindergarten candidates. The purpose of the Instrument is to geparate presohool ohildren into two categorles: (1) those who object1vely appear to be probable early ontrance candidates but require individual evaluations for final Identifioation and seleotion; and (2) those who do not seem to demonstrate sufficient readiness for sohool entry and need no further evaluation. The group test will also be designed to provide an estimate of intelleotual ability.

\section{SIONIFICANCE OP THE PROBLEM}

In reoent years considerable attention has been deroted 
to the preschool aspects and responslbllities of eduoation by Pederal, 3tate and looal govermmental bodies and educational insty tutions. Presently, most manoower, monles, and research centered at this level of eduoation al reumscribes the culturally deprived ohild. At the same time, the mentaliy able child continues to reoelve attention, but not necessarliy at the preschool level.

Desplte repeated research reports on the overwhelmingly favorable outcomes of early entrance to kindergarten programs, the practice is nelther frequently nor widely employed in sohools. of those sohools in the Un1ted States who have Early Admission to Sohool Programs, Individual evaluations requiring competent spocialists are typloally administered to all perspeotivo cand1dates. Th1s 18 neoessary because no oractioal and rel lable means for preliminary soreening is currently avallable.

A presohool group screening devioe whloh could demonstrate suffiolent efflolenoy and efrectiveness in deteoting oandidates most 11kely to be accepted for early admission could make an important contribution to elementary education. To begin with, it could relleve the financlal outlay of those sohools already conducting such programs, and, perhaps, give more sohools an opportunity to begin early admission programs, if finanolal oonsideratlons were presently the major dramback. Of more importance, such an Instrument would offer sehools an coonomloally sound opportunity to 1dentify superior students and provide total sohool 
progrem for the gifted chlld, beginning at the earliest level of formal duation.

\section{SCOPE OF THE STUDY}

The study has potential value for all oducators, partioularly at the presohool and primazy rung of the educational 1adder. In the space age soolety can not afford to negleot the nurture and oultivation of its most preoloug natural resouroes at the earliest posible and ressible age. Seleotion and ldentification of our potential leaders of the next generation plus a diet of generous education opportunities is cruolal in terms of our search and plans for world peace and protection through national defense.

The sample used in the study is confined to wh1te uppermiddle class chlldren residing in a suburban community and therefore is not representative of a oross-seotion of the population. However, many of the early adisission programs are presently looated in suburban areas so the results can be generallzed to such - imilar suburban communities.

\section{QUESTIONS TO BE ANSWERED}

The study involves the development and construction of a group soreening instrument to be used with early admission to sohool candidates. Its userulness will depend upon the test's Characteristios in terms of standardization statistics and 
teohnical information. The data will be analyzed to angrer the following speolf1c questions:

(1) Can rapport be established and alntained in a group setting at the presohool lorel and sudtable test 1 tors be devised and administered?

(2) Does the group soreening test have sufflolent rel1$a b 111 t y ?$

(3) Is the group soreening test valid?

(4) What persentage of onlldren seleoted by tho initial screening test were stentually acoepted for early entranoe to kindergarten on the basis of further individual evaluation?

(5) What peroentage of ohlldren eventually acoepted for early entranoe to kindergarten were looated by the screenIng test?

(6) Does the use of the soreenting test result in savings In terms of professional personnel's time and the outlay of funds in an early admisaions program?

\section{SUMMARY}

This chapter has been ooncernod with a brief sumary of the general methods and rindings regarding acceleration, with the statement and signifloence of the problem, with the purpose and coope of the study, and questions to bo answered. Chapter II presents a review of research and information relevant to the 
problem. In Chapter III the design of the study 18 presented through discussions pertalning to preschool group testing rationale, 1tem selection, and description of the group test. Chapter IV olarifles the method of the study by desoribing the sample and speolfying the general and detalled groun test procedures employed In the collection of the experimental data. Chapter V includes the major findings in terms of standardization statist10s and toohnioal information regarding the characteristios of the group preschool test. In Chapter VI 1s presented the discussion of the results and conolusions derived from the study with atatent of 11mitations, Implioations and recommendations for further researoh in the f1eld. Chapter VII provides a sumary of the overall invest1gation. 
CHAPTER II

\section{REVIEW OF THE LITERATURE}

\section{PRESENT ADMISSION POLICIES IN THE UNITED STATES}

In most states ohlldren are admltted to kindergarten or Plrst grade on the basis of a r1gid onronological age oriterion wth fow exoeptions. For instance, in I111nols all ohlldren who w11 be five years of age by December 1 of a given year may enroll in kindergarten. Th1s seens rather typioal of the country as a wholo according to a survey of admission polloles of systems in the United States reported in 1958 by the Researoh Division of the Mational Education Assoolation. ${ }^{1}$ A total of 532 school distriots, or 83 per cent, responded to a questionnalre originally sent to 642 distriots. Of 417 systems having a kindergarten, 60 per cent reported that a chronologloal age of four years, elght months (4-8) or four years, nine months (4-9) was a prerequisite for adnission. Likewlse, a minimum age of 5-8 or 5-9 was reported neoessary for entrance to flrst grade by 50 per oent of the sohools. Entrance age for kindergarten in the remaining districts ranged from 4-0 to 5-0 with the majority falling between $4-6$ and 5-0. Less than seven per oent of the distriots reported having no established entrance age.

${ }^{1}$ National Eduoation Assoolation, Admission Polloles for Indergarten and Py rst Grade (Washington, D.C.: National 
Over the years changes in minlmum age requirements have tended to move upward rather than downward in direction. The researoh evidence now arallable which suggests that mental age of about $81 x$ or more is a meaningful prerequisite for beginning readIns instruction only when traditional group methods are used probably lead eduoators to ralse the ohronologioal age requirements nigher.

However, some systems are allowing exceptions to the minimur ohronologioal age standard. The above NEA survey indicated about 20 per cent provide for some type of flexible admission procodure. The criteria typlcally employed to adnit underaged onlldron centered around Individual psyohologioal tests of intelligenoe, naturity, and soolal derelopment plus parental conferences.

The Nation's Sohools contucted an opinion poll in 1955 whloh Indicated that slightiy over 50 per sent of the school superintendents in the country farored early entranoe to school based on mental, physical, and emotional maturity in principle. Howerer, most of then did not operationally put this bellef in action due to rarious practioal problems involved in the adrinistration of suon a program. 2

MULTIPLE CRITERTA FOR SCHOOL READINESS

Since an early sohool admission program does not simply

2nshould Beglnning Pup1ls be Admitted on Mental Age? - An Opinion Poli" Nation's Schools, LvI (August, 1955). p.6. 
adrooate lowering the minimum ohronological age miloh would merely sosult in all ohlldren beginning sohool ourler, let us consider other factors, In addition to ohronologioal age, that might be oonsidered. Variables rolated to school readiness would inolude mental age, physioal maturity, emotional and social maturity, and sex The emphasis might well be placed on multiple oriterla since the uze of any one criterion does not appear to be an adequate determinant of sohool entrance.

Onronologioal Ase.

Present kIndergarten programs have been constructed for four and five year old chlldren and quite likely would be unsultable for most younger or older ohlldren. Th1s undoubtedly is one of the reasons why the most common and generally the only criterIon for sohool admission 18 ohronologioal age (CA). Of course, a Mgld entranoe range between four years, elght months and five years, elght months is adminlstratively convenient as well as -learly and easily understood by the community.

Separate studies by Carter, ${ }^{3}$ King, ${ }^{4}$ and Hamelaenin ${ }^{5}$ indicate that younger ohlldren entering kindergarten and f1rst grade

3L.B. Carter, "Effeot of Early Sohool Entranoe on the Soho Lastio Aohleroment of Elementary Sohool Chlldren in the Austin Pub 11. Sohoo1s", Joumal of Education Research, I (October, 1956), pp. 91-103.

4. B. KIng, "Effect of Age of Entrance into Grades 1 upon Aohlevement in Elementary School", Elementary Sohool Journal, LV (Pobruary, 1955), pp. 331-336.

5R. S. Hamaleenin, "Kindergarten - Primary Entranco Age in Relation to Later Sohool Adjustment", Elomentary School Journal,

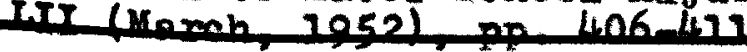


do not subsequentiy achiere or adjust as well as older onildren anong unseleoted samples of chlldren. Green and Simmons found a positive relation between soores on readiness tests and age. 6 As they point out, howerer, In most studies the size of the Initial differenoes between students was not known and to say that older anlidren learned wore 18 to as wume that they did not know more In1t1a11y.

Porrester compared sroups formed on the basis of $\mathrm{CA}$ and MA. I1. rindings indicate that old-bright pup1ls excel throughout their eduoation and joung-bright students have diffioulty after junior high.? This study 18 one of the very few investigations whioh does not lend support to early admission of academioally talented on11dren.

The above studies demonetrate that CA should definitely be considered as a rariable in sohool adnission, but not neosssarty the only one. Over a wide age range CA does oorrelate with auch rarlables as nontal age, soolal and emotional maturtty, and physioal size and coordination. For instanoe, one rould be safe in predioting that a fifteen year old onild would have a higher mental age and show more soolal, emotional, and physioal naturity than a I1Te jear old ohild. Howerer, when age range is restricted to one

\section{${ }^{6}$ D. B. Groen and S. V. S1mons, "Chronologloal Age and} Sohool Entranoe". Elenentary Sohool Joumal. IXIII (Ootober, 1962) pp. $41-47$.

7J. J. Forester, "At what Age Should a Child start Sohoolr" Sohool Exeout ive, IXXIV' (May, 1955), pp. 80-81. 
of two jerrs, CA greatly loses its predictive power of these same rartables.

In kindergarten one 1 s likely to find ohlidren who, although the1r mean age may be approxinately 5-0, alfrer in MA two to throe gears. Th1s is a tremandous difrerenoe at any age. The Baldrin-Hood tables show that average pive yoar old boys rary phystoally from 37 to 47 inches in helght and 32 to 49 pounds in we1ght. If you put together all boys 42 inches tall, they would probably range in age trom 4 to 8 years. 8 These examples highlight the great ramations present in all areas and soberly indicate that there 1 s no one ortterion by whoh all ohildzen oan be groupd a alke exoept sex. Rigld adherenoe to a onronolosionl age ilnit megests that gohools are not adapting to the noeds of, at least, one-thind of its students. It pleces unreasonable haxdshipe on the slow ox handloapped and 1 gnores the needs of the bright. The eument means of school admission seems ridialousiy unfelr and waterul of humn talent; jet wost achools relisiousiy oontinue and waintein 1t. Individual alsferences point to the need for Al rerential treatment in education. By falling to provide for exeeptions, sohools mes be dolng sexlous personal and educationel Injust $10 e s$ to many ohl1dren.

\section{Beldwin, B. I. "The Physloal Growth of Children from} Diwh to Matumt " University of Iowe Studies of Chlld We1rare, 10. 1.1921 . 
Terman found that highly intelligent chlldren tend to be taller, more healtiy and somewhat better adjusted soolally than average. 9 Thus, admitting younger but brighter ohlidren would mean they are more apt to be like the group ohronologloally one year ahead of then than theif real peer age group. With this perspeotlve one may easily axgue that other factors should be considered for sohool admission.

Nental Age

Mental age (MA) appears to be the single best predictor of cohool achlevement at elementary grade levels as measured by inAlidual intelligence tests. Kazienko demonstrated that MA was rexy signifloantiy more influentlal in deteraining Grade 4 achevemont than $\mathrm{CA}$, IQ, or a combination of both. ${ }^{10}$ Hobson has einployod MA as a oriterion for sohool admission sinos 1932 and found it to be a conslstent and workable prediator. ${ }^{11}$ Biroh supported a elmilar flnding. ${ }^{12}$ stake has dereloped tables whioh demonstrate

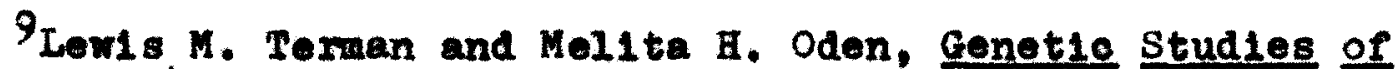
Conlus, Vol. 4, "The Gifted Child Grows Up" (Palo AIto, Callf.: Btandard UnIversity Press, 1947), p. 448.

${ }^{10} \mathrm{~L}$. W. Kazlenico, "Beginner Grade Influenoe on Sohool Progress," Eduoationel Administration and Superrislon, XC (Apri1, 1954), pp. 219-228.

$11 \mathrm{~J}$. R. Hobson, Mental Age as a Workabla Criterion for Bohool Admission", Elementest sehool Joumal, XIVIII, (Pebruary, 1948), pp. 312-321.

12 Jaok W. Biroh, "Egrly Sohool Admissions for Kentally Adranoed Chlldren", Exceptional Children, XXI (Decomber, 1954), pp. 84-87. 
the relationships between presohool mental ages and future elementary school achievement levels.3. In addition, social and emotion al maturity seem to be more closely related to MA than CA. Werner disoovered that variation among five year olds in soolal age ranged from 4 Jears to 7 years as measured by the Vineland Social Maturity Scale but found a positive oorrelation betwoen social age and MA. 14

The Revised Stanford-B1net Intelligenoe Test, Form L-M, by Terman and Merrill is the test generally used to evaluate the Intelizgenoe of children. 15 Many persons have questioned 1ts re11ab1lity, especially at earlier age levels. Th1s 18 a legltimate oonoem Inasmuch as this test does have higher rel1ability at older ages, but the work of Bayley inaloates 1ts rel1ab11ity at school-entering ages is adequate enough to be of considerable usefulness. 16

13R. F. Stake, "Predioting suocess of the Early starter", Orerviex, (November, 1960), pp. 32-34.

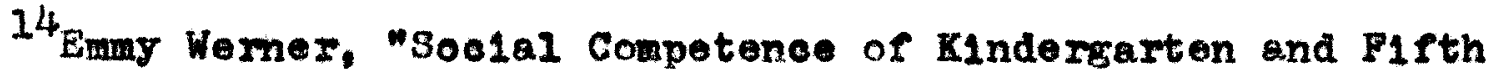
Grado Chlldren as Evaluated by the Vineland Soolal Maturity Scale" (unpublished Ph.D dissertation) Department of Eduoation, Universit of Nebraska, 1955).

15tows M. Terman and Maude A. Merr111, Stanford-Binet Inte11 isence Scaie. Fom L-M, (Boston: Houghton Miffin, 1960), p. 363.

${ }^{16}$ Nanoy Bayley, "Cons1stenoy end Varlab1l1ty in the Growth of Intelligenoe rrom Birth to Blghteen Years", Joumal of Genet1o Parchologx, LXXV (June, 1948), pp. 165-169. 
Soelal and Emotional Maturity

In most of the early entrance programs ratings of soolal whavior and emotional maturity are typically a part of the seleotion oriteria. Kindergarten teachers in partloular, show deep conoern over possible diffloulties underage ohildren may have in these areas. Sometimes the school psyohologist uses tests, such as the Vineland Soolal Maturity Scele, besides test behavior observations in Judging the maturfty of youngsters.

As noted previously, social maturity correlates more high15 with MA than CA. Hobson ported in a ten year follow-up study that underage ohllaren admitted by test not only exceed others seholastically but on the average were referred less often for motlonal, soolal and other personality maladjustments. 17

Mueller asked teachers to rate orer 4,000 ohlldren in kindergarten through fifth grade in various sohools in Nebraska on several oharaoterist1os. 18 Her results indioate that carly ontrants admitted by testing stand better, whether in terms of number reoelfing high ratings or of the fex reoelring low ratings. The younger-bright group were signifloantly higher than regular elasses in achlerenent, helght, ooordination, acoeptance by others

17 Hobson, op. o1t., pp. 312-321.

$18 \mathrm{~K}$. Mueller, "Suocess of Elementary students Admitted to Public Schools Under the Requirements of the Nebraska Program of Early Entranoe", Dissertation Abstracts, XV (June, 1955). 
attitude toward sohool and orotional adjustment as judged by tenoners.

\section{Mratoal Matumtr}

In zeneral, Gifted onlidren tend to be taller, hearler. and to possess botter physloal ooordination than arerage ohlldren of a comparable age. The researoh eridenoe of Terman and odon, 19 olson and Hughes, 20 and Hollingworth ${ }^{21}$ is quite olear on this polnt. That phrsical maturlty ahould be factor to consider for encly entrance to sohool, howerer, is questionable. In his revier of the 11terature, Reynolds states *. . there is no eridenoe that phyaloal development is a relevant variable in determining wother or not ohllaren ahould enter sohool carly. It 18 more Important to asoextain that the ohild is in good health than to leam whether he 1 s tall or short, stooky or thin, well-coordinated or awkmard." 22

\section{en}

A comparison of the sohool adjustment and aohierement of

19 Terman and oden, Vol 4, op. att., pp. 448.

20W. C. 01son and B. O. Hughes, "Growth Pattexns of ExoepSLonal Ch11dren". Yearbool of the Hattonel Soaletr for studring

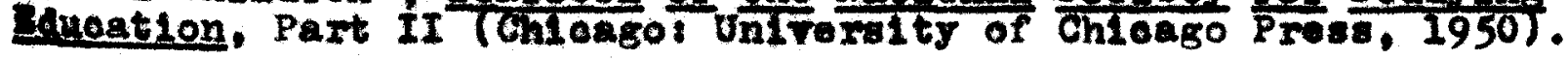

21 Lota s. Ho112nsworth, Gifted Gildren: Thetr Nature and unture (Now Iork: Maomilien Co., 1926), pp. 374.

22 Maynard C. Rejnolds (od.), Eartr Sohool Admiseton for

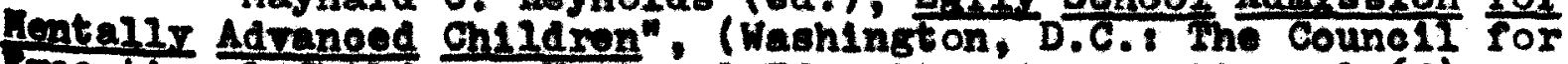
wrooptional ChIIdren, Iational Eduoation Assoolation, 1962), p.56 
boys and girls in elementary school, will no doubt result in the finding that boys tend to have more problems than $81 \mathrm{rls}$. Based on such data, different admission standards have been proposed in terms of sex. Pauly feels boys should be admitted at an older age than 81 rls. 23 Maxrell specirloally adrooates starting girls at f1ve years of age and letting boys woit unt11 they are six or eren older. 24 Such a general procedure seems questlonable sinoe there is considerable overlapping, 1.e., a sizable number of boys would be ready for sohool at ages deomed satisfactory for girls. JudgIng each individual on a variety of school readiness oriterie. seems more reasonable then using the gross index of sex. As Clark suggests, "educators need to deal with the wide range in variabilIty in both mental ab111ty and achlevement of pup1ls irrespective or $\operatorname{sex} \cdot n^{25}$

There is eridence to indleate that girls derelop language fac1lity earlier than boys. This is reflected in some studies whion report more girls than boys tend to qualify for early adm1381on to sohool. Howerer, at later ages the language ab1lity of boys and g1rls appears to be about equal. Different school admission rates solely on the basis of sex do not seem rarranted.

\section{F. R. Pauly, "Should Boys Inter School Later Thon G1 rasp} Netional Education Association Journal, XII (January, 1952), pp.293. $24 \mathrm{~J}$. Maxwe11, "What to Do About the Boys?", Nationel Eduoation Assoclation Joumal, XIIX (March, 1960), p. 26.

25W. W. Clark, "Boys and Girls: Are Thero Signiricant Abli1ty and Achievement Differences?", Phi Delta Kappan, XII (November, 1959), pp. 73-76. 


\section{PRACTICAL PBOBLEMS OF EARLY ADMISSIOK,}

It is readily apparant that the striot ohronologionl age requirement by itself 18 inappropriate from a research or rational viewpolnt. It does not take into account new advances in teaching nor the wide range of Individual isfrerenses in ohildren at any age. Yet, fen schools have adopted a flextble sohool admission progran.

The major barrior to adopting an oarly admittance procedure appears to hinge on the administrative diffioulties whioh it may oreate. The 1dentification of certain practioal problems have prevented educators from translating thel $r$ thoughts and 1deas rerifled by researoh into practioe. Thus, by thoir inaction they tend to perpetuate the rigld onronologloal entrance age and think of any other prosedure as operationally infessible without naking a oonesntrated effort to surwount the onvisioned administrative dieflasultes.

Reynolds has 1dentified five practical problems involved in the establishment of a progran of sarly admission for bright chlldren. 26 The flrst problem involves the establishment of speciflo oriteria for early adinssion. This refers to the selootion of multiple oriteria based on research and adapting them to

$$
{ }^{26} \text { Reynolds, op. alt., p. } 5 .
$$


the peoullarities of an individual school distriot. A sohool system located in a high soolo-economic community may need to set nigher early admission standards than a school in a deprived area. In a previous section possible rariables to be included in a seleo tion criteria were noted and thelr arrangement and interaction wil be further disoussed in the descriptions of ourrent programs in the latter section of the ohapter.

Screening and evaluation of ohlidren poses a second proble since speolal personnel and resources are required. Early sohool admission demands extensive eraluation of ohlldren and could be a major, costly undertaking in sohool systems lacking psyohologloal servioes. Those programs ourrently functioning use exclusively individual testing and interview teohniques in determining eligibil1ty. Most distriots do not employ school psyohologists as regular staff members. To contract a psyohologist for the purpose of conduoting an early admission program results in an additional outlay of funds. Even then, not all potentlal candidates are soreened be oause schools rely on parental requests. To reduce costs, yet soreen all candidates, this investigator adrocates the development of group soreening tests for all candidates followed by Individual evaluation for those who appear ready for sohool. With such a uniform procedure no candidates would be overlooked and the program would be 1088 costly. In addition, some states relmburse distriots which provide additional servioes to academically talented students For example, in IIIInols under the provisions of Senate B111 749, 
Serenty-third General Aaeembly, the Superintendent of Public Instruction with the adrice and consent of the Adrisory Councll or sduoation of Gifted Chlidren, is authorized to onter into contract with sohool distrlots, oolleges, and unirersities for the conduetion of denonstration oenters, experimental projects, and inst1thes in the fleld of education of glfted ohllaren. Relmbursement for services, material, and personnel are also provided to sohool distriots and followhips are avallable for graduate students who plan to specialize in the area of glfted onlldren.

Provision for classroom spece oould concelvably be a third problew in some alstriote since early admission results in temporary increase in enroliment. This can be controlled in terms of the standards regarding flexible adnission. For example, if the present minimui a in a state says a ohild must bo 5-0 by Deoember 1 of a glten jear, the early admittanoe program can concern itself with only Deoember birthdars or as many months it wishes to go back depending on 1 ts resourees, funds, and personnel.

Pub210 rolations preaents a fourth problem. The program must be interpreted to school persomel, parents, and the oomunIty 28 a whole In order to galn thelr support. Those sohools which have enoountered diffloulties wight have had more successful prograns had they concentrated on this aspect.

A Ifth problem Involves appropriate supervision and continuous evaluation of the prograx. Barly entrance does not con- 
cern itself merely wh deternining whether a child seems to be ready for school at an eeriler ago or not. It should be vieved as one phase of the gifted program which is, in turn, an integral part of the system's total sohool program. As part of an ont1re school program it has a higher probability of recelving adequate supertision and evaluation.

\section{DISTRICTS DISSATISFIED WITH FLEXIBLE ADMISSION PROGRAMS}

Ind1viduel psyohologioal evaluations are oonduoted and sereral aspects of sohool readiness are generally employed to select early entrants. When such seleotive prodedures are applied, early sohool admission seems to be a favorable form of acceleration.

However, Park Forest, Ililnols, discontinued thelr flex1ble admission program in 1955 as reported in Time. 27 Due to overorowded schools, parents of ohild ren who reaohed five between September and December were notifled that thelr chlldren had to take standardized tests for entrance. The evaluatlons were explained as an attempt to maintain high aoademio standards. An exan fee of $\$ 7.00$ was onarged. Psyoholog1sts evaluated 203 children of wioh 135 were rejected. Parents of those chlidren denled entrance became enraged and protested to the superintandent and sohool board. A lawyer, whose son was rejected, insisted it was 11legal and took the case to oourt.

27"Hopplng 11ke a Bunny - Kindergarten Admission Pol1cy," Time, LXVI (September 5, 1955), p. 45 . 
The State Superintendent of Public Instruction deolared that the tests were not in conformity with the sohool oode. Further, he Indicated that entrance to kindergarten had to be basod on partioular age requirements, not on maturity of the child. As a result all the ohlldren were allowed to enter kindergarten.

Most sohools that develop flexible admission programs do so to allow joung-bright youngsters who are ready for sohool to bef gin. earlier than they would be able to under rigid CA requirement The motivating force behind the Park Porest program, although couched in terms of aoademio exoellence, was basically to reduoe the number of kindergarten youngsters entering sohool who were actually eligible in terms of their age to relleve overorowded oond1tions. In addition, a questionable fee was charged, undoubtedly to dissuade some parents from having their ohildren tested. In view of the procedures used it can readily be understood why parents objeoted and casily gained a polloy reversal.

However, there is at least one case reported by Mawhinney In the literature of a distriot whioh dropped its early entrance progran after fourteen years of experienoe. 28 The reasons for disf continuing the program centerad around the aotual experience of chlldren who entered early, the reaction of parents of chlldren who were denied entry, and the expenses of the program.

\section{${ }^{28}$ Paul E. Mawhinney, "Wo Gave Up on Early Entrance",} Mlohlgan Eduoation Journal, XLI (May, 1964), p. 25. 
The records of 386 early entrants who had remalned in the distrlots were reviewed and the1r teachers were asked to evaluate the1r soolal and onotional adjustment, demonstration of leaderahip. and aosdemic status. The results suggested that about one-third (30.6 per cent) of the carly entrants were poorly adjusted. About one in twenty was judged as an outstanding leader whereas nearly three out of four were considered lacking in leadership. Approximately one in four ( 24.4 per cent) was rated aoademioal1y super1or but the same amount ( 25.3 per oent) was considered el ther below arerage or had ropeated a grade.

The majority of parents whose children were refused entrance reportedis reacted negatively. Most of them showed disappointment and surprise but fer were angry and bitter. Others attaoked the competency of the school staff and complained to sohool board nembers. Conversely, anall number expressed confldence in the judgment of pajchologlsts.

Ninety-e1ght of 197 ohildren eliglble for testing were evaluated in the sumer of 1963. Of these, 55 were refueed entrance and 43 were acoepted but only 30 entered school. The expenditures for these 30 ohlidren (whloh actualls inoluded operation of total seleotion process involving 98 onlidren) was caloulated in terms of one month and a half seoretarlal serrioe, more than a month for two psyohologists, and partial teaoher and classroon oosts. 
Having examined the difficulties that two school districts nare encountered in attempting rlexible ednission polloles, let us compare and contrast these data with the seleotion criteria and eveluations of early entrance programs whioh have proven successfu.1.

\section{DESCRIPTION AND RVALUATION OF EARTY IANTHANGE PHOGHAMS}

Evanston, I111no1s

In IIIInois a child may enter kindergarten if he is fire by December 1 of a given year. Since 1940, In Evanston, children have routinely been admitted to kindergarten if they were sive by December 31. At the same time, younger chlldren with January, February, or Maroh bl rthdays were allowed to enter if recommended on the besis of Individual testing, followed by a six-week trial perlod. It should be noted that as early as 1926 slmilar services were offered on smaller scale. if parents requested that their chlldren be tested for school readiness.

The Evanston rlexible admission program follows these procedures. Parents complete a request form for the testing in the spring. After this initial step in the screening prooess, they are seen by a psyohologist during the sumer months. The Stanford Binet Intelligence Test, Goodennugh Draw-a-Man Test, and clinical observation and fudgment comprise the evaluative technique ut111zed. Besldes intellectual ab1l1ty, physleal, emotional, and soctal readiness are considered in determining acceptance or 
rejection. No specifie $\mathrm{KA}$ or IQ cut-off limits are employed, but it is unoommon for a child below an IQ of 120 to be acoepted. The sohool's deolsion is glven to the parent lmmediately following the ohlid's Individual eraluation. If the chlid is aocepted, the parents are reminded of the trial period and told they w111 be asked to withdraw their youngster if the experlence does not seem in the best Interests of the ohlld or his peer group. Each year, out of approximately 100 onlidren evaluated, about 20 are accepted.

Studies of this program aumerized by Milier indicate that in comparison with the1r classmates, early ontrants rarely achleve below the average and often achiere at the upper 11mits of the class. As a group the joung acoelerants tend to inoreage their relative standing os they progress in sohool. A study inrolving fifth grade youngaters indloated that only six per oent of the early entrants scored below the f1rst quartilo on an achievement test as compared wth 25 per oent of the older youngsters. In another study no significant differenoss were found between the acoelerant and nonaccelerants in terms of teachers' marks, teachers" rating soales, 11 bram reading ert raourmoular activities, creativity in writing, drama and musio, and peer rat1ngs. This combined data sugsested that childron adulted to sch001 early by test compare farorably with thelr older olassmates.29

29Vera V. Miller, "The Early Admission Program in Bvanston Illino 18". Barly Sohool Adrieston for Keritally Adrenoed Ch11dron,

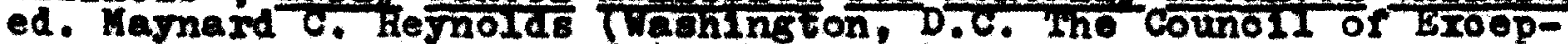
tlonal ChIldren, MEA, 1962), pp. 31-34. 
Erookline, Massachusetta

The Brookilne Sohool Distriet initlated a Rexible syatem for sohool admission in 1932. The major reasons for instituting the program centered around meeting indiridual differences, allowIng bright ohildren to oomplete thelr eduoation a jear earlier, and repleoing the, then, popular method of acceleration (gradeakipping) whion was recelving wuoh justiflable oritiolsm.

The alninum age for admission to kindergarten was and precently is 4-9 by 0otober 1 of a given jear. In 1932, ohlidron who were within three months of the deadine, were regarded as candidates to be tested. Any onildren in this group (4-6 to 4-8 inoluive) were accepted on tmal basis if they passed physloal and health examination and gained an $M A$ of at least 5-0 on the stanford-Binet soal of 1916. In the rears that followed, ohildren with $\mathrm{CA}$ 's between 4-0 and 4-8 were considered ellgible for testing.

Researoh on the progran indionted that the 1east suocesstul group of underaged ohlldren were those who had been admitted wth a of 5-0 (minimum requirement), and the next least success. rul sroup were those onildren nore than six wonths underage chrom logloa11y. As a result of these sindings in 1944, the minimum MA requi rement for tmal admission ma ralaed to $5-2$ on the 1937 Revision of the stanford-Binet seale, and the priviege of early admiseion was I1mited to ohildren within six nonthe of the minimm 
CA requirement of all ohllaren $(4-3$ to $4-8$ Inclusive).

Only about two-thirds of epproximately 250 annual possible oandidates are presented for eramination by the1r parents. Or these, about 50 per oent are admitted on trial basis. Any ohild found Ineligible is automatically granted one or more retests upon parental request. Soolal and omotional derelopment and maturity are determined during the standardized eraluation procedure by the psychologist. Form letters are sent both to parents whose ohildren are accepted and those who do not qualify. Results of the psychological examinations are disoussed with parents by appointment or over the telephone only after reoelpt of the letter. Parents are rarely asked to withdraw their ohild after the trial period.

As one would expect, the reaction of parents whose ohlldren were admitted was satisfaction and some of the parents whose ohlldren did not quallfy showed displeasure. However, the superIntendent and Board of Bducation entertained all Inquiries but vigorously opposed personal and political pressures which resulted in a smooth operating program.

In terms of school staff, the admdinitiatope acopted the program and oooperated to insure its success. Hoverer it should be noted that the kindergarten teachers, possibly due to thelr blrthday consolousness of kindergarton ohildren, basloally opposed the program. Th1s was reflected in their comments to parents and 
retings on the oumulative rolder.

In 1948 Hobson reported his findings ooneeming the r1rat flre and ten yoar roplode of the operation of this rlerible adwlabion prograp. HIs earlier researoh indloated slenificant hlgh positive correlation botween at ontranos and tesohers' warks and eohletenent through grade four. Bowever, In kindergarton maxks were lower for the underage young atere but thels average ratings on standardized roading readiness tests were hlgher.

The ton year follow-up atudy conflrwed the above data. In eddition to the findings whioh $10 d$ to the ohanges in minlaun MA requl remont to 5-2 and the liwiting of the progran to ohlidren withIn $11 x$ monthe of the minimu a requirement, the data showed that, (1) the aargin of average euperlority of seleoted undernge ohlldren increased as they progressed through olght srades of elesentary sohool, and (2) the ohildron ontering sohool early oroseded othore soholastlcally as woll as belns refarred lesa often for - motlonal, soolal and othor personallty maladjustments on the average. 30

In 1963 Hobson reported the remults of twenty-three jears experienoe with thls program whloh involved 550 graduates who had entered sohool ear1y and 3,891 other craduates. One thousend one hundred sixty-fre ohlldren aotually were adnltted to sohool

30 Hobson, Elenentary Sohool Journal, xLVIII, pp. 312-321. 
early by teste during this perlod of time but only 550 romalned through graduation. Sinee more than one-half of the underage onildren moved away prior to graduation, the results that follow are based on the assumption that no selective faotor is afrecting the researoh. Convervely, it should be noted that by grade $81 x$ an equal emount of underage chlidren nove into thelr distriot as are admitted by tost, and by grade nine twioe as many have entered. The lower ontranee ages in adjecent olt1es apparentis acoounts for this phenomenon.

Results of the investigation indioated that:

1. The academis supertority for the underage ohlidren admitted by test witnessed In the elementary sohool oontinued and was somewhat increased in high sohool. There was a sifificant alfferonoe to whioh the underage group surpassed their olassmates in the percentage of destrable marks, arerage rank in olass, and in percontage graduated with honors.

2. The underage group part101pated in a signifloantly larger average number of extracurrioular activities during hlah school. Thls inoluded soholast10, athlet10, and soclal honors plus eleotive positions.

3. The underage accelerates roosived twloe as many graduation honors, awards, and distinotions than their 
fellow studente.

4. A semifloantiy larger peroentage of the underage grad uates applied and rere acoepted in aooredited rour rear colleges than thelr olassmates.

5. The early adnission of youngsters within a fow months of the usual adnigsion age by test seens to be an excellent means of providing for individual differonoes In the inftial phase of eduostion.

6. The adminletrative probleas of an early sohool ontranes prograx are core imaginary than roal. 31

Minneapol18. Minnesota

Children who are rive on or before December 31 may enter kindergarten. Prior to 1935 eariy adnission was determined by the prinolpal who would interview the parent and ohild and admin1ster the Detrolt Kindergarten Test. The deolsion was based on the prinelpal's appraisal of the ohlld's maturity and Intelligenca

By 1935. parohologists were emplojed to adninister indirid ual Stanford-Binot tests to oundidetes after preiliminary goreenIng and referral by the prinelpal. All aspects of the ohIld's

\section{James R. Hobson, "High Sohool Performance of Underage} Pup11s Inttially Aditted to Kindersarten on the Basis of Physioal and Pajohologloal Testa" Educationel and Psrcholosloal Measurement, XXIII (spring, 1963), pp. 159-170. 
developmental level were considered, but intelligence was the eajor factor. The out-off limit stated a ohlld must have a MA one month above 5-5 for each month of ohronological age below 5-0. No such MA 11日it is currentiy enforced and ohlidren born after January are also now eligible for testing.

Presently, any parent may request that hls ohlld be tested for early ontranoe. This is accomplished by kindergarten registration in the spring or prior to the opening of sohool. The prinolpal eraluates the child's general information, rocabulary, Interests, aotifities, phssioal s1ze, musoular coordination and oase of separation from h1s mother. The parent 18 then interviewed and, if the prinolpal feels the oh1ld 16 a possible candidate, he refers the youngster for a psyohologioal study.

Paychologloal evaluations are soheduled for a three week perlod beginning two weeks prior to the opening of sohool. Typ1cally, the ohlid is adninistered the Stanford-Binet, Form L-M, and is asked to draw a man, do some free hand drawng, take a ploture rocabulary test, or perhaps, partiolpate in number sames. The payohologist obeerves $\mathrm{hls}$ bohariox and reaponses in these activities and tay further interview the ohild. A parental interFiew ugually follows. The psychologist's reoomendation is based on all the arallabse dita, nanely, the deseription of the prine1pal's interaotion with the oh1ld, tests and observations of the oh1ld, developmental history, and parental interview. The final 
decision rests with the prinoipal who notifies the parent. All carly adisisions involve trial perlod.

Due to the fact that the early entranoe progran has been In effeot for so many years, parents and sohool personnel seom to accept it read11y. However, kindergarten teaohera may ask to have a case reviewed, If a ohild is having diffloulty. Some of the ohlldren are informally followed-up by the perohologiet.

Holbrook roported a deseriptive evaluation of joungsters admitted early over a two jear period. 32 Questionaires wero sent to prinolpals and teaohers regarding those acoelerates who were in kindergarten and rirst grade. The regults indioated that 89 ohild ren ( $58 \mathrm{gtrl}$ and 31 bojs) had been admitted early during the two year period. The range in IQ was between 107 and 164 . The teachers Indisated that they bellered 57 of the early entrants ( 39 girls and 18 boys) were definitely in the oorrect placement in school and certainly should not have walted jear. Nineteen of the ohlldren should have walted jear acoording to the teachers, and 13 others were questionable. The mean IQ of the ohildren described as successful was 138 as compared with a mean IQ of 124 for the unsuosessful group. Seven ohlidren with IQ'a below 120 were all found in the latter sroup. Teacher complaints centered around soolal and motional problems. Howerer, it 18 questionable

32 Sarah F. Holbrook, "The Early Adnission Progran in M1nneapol1s, MInnesota," Early Sohpol Admisgion for Mentallr Adzanced Ch1ldxen, ed. Maynard C. Bernolds, 1962, pp. 35-42. 
to asgume that suoh problens would be $108 \mathrm{~s}$ if the ohildren walted an additional jear. It 1 entirely posalble that they might have been more serere.

Nebresira

In 1939 the leglslature of the State of Nebraska, at the request of the State Department of Publio Instruotion, passed a law designating that no ohild may onter kindergarten unless he was I1ve jears old on or before Detober 15 of the current jear, and no child may enter grade one unless he was $81 x$ by oetober 15 or had completed kindergarten. Or most importance was an added prorision which Indicated that a sohool oould admit to kindergarten a onlid who was younger than the st1pulated age if he showed readiness as determined by oriteria set by the state Department. InItially, chlldren were acoepted in kinderserten if they had $\mathrm{MA}^{\prime} \mathrm{s}$ of 5-0 by September 1 on the basis of Ind1vidual1zed, standardized teats of the Stanford-Binet type. By 1949 a state Department not1ce stated that the examination results were to indicate an MA of at least 5-3 as of September 1 . Th1s would be considered only one of sereral orlterla with careful consideration belng given to soolal, emotional, and physical naturity. The recomended minimum for these related areas was 5-0. It was further recommended that chlldren with January or later blrthdays not be examed. The MA requirement was agein changed and raised to 5-6 in 1955, not on the basis of researoh evidenoe, but in an effort to insure the 
success of early entering chlldren by demanding a higher minimum level of ab111ty. Examinations take place between June 1 and September 15 of a given Jear. S1noe the early entranoe programs are governed by permissive, rather than mandatory leglslation, Nebraska school systems may refuse to adnlt anj chlldren on the bas1s of tests, or demand higher standards than recomended by the State Department of Education. If sohool has an early entrance program it relies on parental requests for testing of their children. Some sohools have set thelr MA minimum as high as 6-3. This tends to more eseure a chlld's suocess but it exoludes many who could quite I1kely sucoed too.

Woroester summarlzed several researoh studles on early entrance to sohool in the state of Nebraska in whloh the average early adnittance age was elght months below the regular entrance age. 33 In general, the studies showed no significant differenoe In physiodl development of early entrants as compared with arerage chlidren. Acadenleally the acoslerates equalled or surpassed the1r older classmates. Teacher ratings indloated they were well adjusted, acoepted by the1r olassmates, 11ked school, and had good or better coordination. No negative effects were roported. Worcester reoownended adnltting onildren who would be flve by January 1 if they showed readiness on the basis of mental ability equivalont to an $I Q$ of 110 or more as a justiflable educational

${ }^{33}$ D. A. Woreester. The Education of Cnllaren of AboveArexase kentel1tr, (Linoolnt Un17ersity or Newaska Press,1956) 68 . 
pol10y.

Smlth compared 175 early entrants with a random selection of 175 chlidren whose birthdays came before October 15 of the year they entered school. She found that the younger group was just as ready as the older youngsters to read in flrst grade, 1.e., reading readiness was more related to wental abli1ty than CA. During elementary sohool the early entrants recelred somewhat better grades than the oontrol group. The jounger group soored higher on a soolometrio instrument in which onlldren were asked to choos: their best frlends. Teachers' ratings of the children indicated no difference in terms of enotional and social adjustment. Smith concluded, "If we exolude ohlidren whose fifth or sixth birthdays come after 0stober 15 of the ourrent jear from the xindergerten or first grade, are faling to serve some of those who oould succeed in sohool". 34

Monderer compared a group of 138 early entrants with 468 chllaren. 35 He emplojed several grouplngs. No sex differences were found in academio achlevement or social adjustment between the accelerates and regular entrance students. In second group he found signiflcant differences in achlevenent and sooial adjust-

\section{$34 \mathrm{~J}$. Smith, "The Suooess of Some Young Children in the} Lincoln, Nebraska Public Schools" (unpublished Master's dissertation, University of Hebraska, 1951), p. 63 .

$35 \mathrm{~J}$. H. Monderer, "An Evaluation of the Nebraska Program of Early Entrance to Elementary Sohool" XIV (Dissertation Abstreots $1954)$, p. 633. 
ment favoring the pupils adnitted eariy along with trends suggestIng that their superiority increases as the jounger children prograss through sohool. In his thind group, no signifloant differenoes in rating between the early entrants and regular students was noted in rural schools. He coneluded that early gocelerants are just as suocessful, if not nore so, than regular entrants in terms of academic achlevement and social adjustment.

Pennsylvanta

In Penneylrania, the minimum age for entranoe to grade one is 5-7 as of September 1 of a Btren rear. Cnildren orer 5-0 but 2es8 than 5-7 may enter on the rooomendation of a psyohologist. Youngsters are evaluated by test for reading readiness and superlor mental ablitty and by Interview for soolal, emotional and physloal maturity. An IQ of 130 is typloalig used as a cut-orf point although sone have been accepted below this measure.

Birch reported that the results of a one to three year followm study in Pittsburgh indioated that an overwhelming major Ity of ohildren admitted early to 1 rgt grade were making aatisfaotory sohool adjustments in all areas, namely, academic, coc1al, emotional, and phys10al. 36 He belleves the best method of acoelcration is through early entrance and adrocates that every ohild should be evaluated before entering kindergarten.

36. B1 roh, Exoeptional Ch11dren, XXI, pp. 84-87. 
In Warren, Pennsyltania a Demonstration Projoot regarding early entrance began preparations in 2961 supported by rederal, state and looal funds. ${ }^{37}$ A presohool oensus was used by the supenintendent to invite the parents of those ohildren who would ordinar1ly be el1gible for kindergarten in September, 1963, to have thelr chlldren evaluated during 1961-62. Psycholog1sts admin1stered the Standford-BInet, Goodenough Dran-a-Man Test and rated exch ohild's behavior in terms of social and emotional maturity. Parents completed case history forms and were responslble for harIng thelr ohild's health oheoked. Of a possible 257 candidates, 229 were examined and 37 were recomended by the psychologist for early admission based on mental, soolal, emotional, and physioal maturity. These ohlldren were then observed in nelghborhood kindergartens by experienced teachers. A school committee studle the observations of the pgyohologists and teachers and acoepted 26 of the 37 ohildren. Th1s represents 10 per cent of the orig1nal number and 11.6 per oent of those examined. Since the parents made the ultimate deolsion regarding early ontrance, 19 chlldren entered sohool early in September 1962.

Recent results indloate their adjustment to sohool was no more difficult than for regular students. On reading readiness tests at the end of kindergarten the regular pup1ls ranged in

37Jack W. Biroh, W. David Bamey, and Willian J. T1sdall, "Early Admission of Able Children to School: The Warren Demonstra tion Projeot", Sohool Life, XLVI (June, 1964), pp. 7-8. 
percent11es from 0 to 99 and the early entrants between 29 and 99. The mean IQ of the 19 ohlidren were found to be stable when examined by different psychologists at the end of the year. All were promoted to first grade and except for one were progressing sat1sfactorily. Soolometrio ratings indicated they are acoepted as well as regular puplis.

\section{UNDERAGE HIGH SCHOOL AND COLLEGE STUDENTS}

Early admission to kindergarten or f1rst grade typloally results in oollege students who would be ocnsidered underaged in comparison with the1r classmates. Keys oarefully studied a sizable amount of researoh conducted prior to 1938 regarding the effects of acceleration as demonstrated in oollege students. Results of these studies overwhelningly favored the underaged student on all counts. Not onls was the underaged student more successful academioally, but he also excelled in measures of soolal and emotional adjustment.

Keys also reported on researoh he completed whloh assessed the relative suocess of underaged $\mathrm{hlgh}$ sohool and oollege students In the State of Califomia. His findings showed the underage student to be superior to hls peers on all measures of adjustment. In addition, they outperformed average-aged students of comparable Intelligenoe. Keys conoluded that ". . the Indications are strong that soolal age raries with mental, and that insistence on regular promotion acoording to ohronologioal age for pup11s with 
IQ's of over 120 is not only of no benefit but an actual detriment to their social development and adjustment". 38

Pressey reviewed research up to 1949, and reported that in the vast majority of cases the underaged oollege student not only equalled, but actually surpassed his peers in all respects. The same finding held true in Pressey's research concerning underaged students at On10 State Un1versity. He wrote, "In short, the ev1dence was practically unaninous that younger entrants were more $11 \mathrm{kely}$ to graduate, had the best aoademlo reoords, won the most honors, and presented the fewest disolplinary problems." 39

Toman and Oden attempted to determine if age at graduation had any effect on a number of adjustment variables in Terman's original sample of gifted persons. The measures, taken when these people were in middle 11fe, showed the youngest graduates to have exoelled or equalled others in the sample in orerall $11 \mathrm{fe}$ adjustment. 40

38, Keys, The Underage 8tudent in High Sohool and College (Berkeley: Untrersity of Callfornia Press, 1938).

39 sidney I. Pressey, "Eduoational Aoceleration: Appralsals and Bas10 Probleng". Bureau of Edueatlonal Monographs (Columbus, Oh10: Oh10 State University, 1949).

${ }^{40}$ Lew1s M. Terman and Melita H. Oden, Genet1o Studies of Genlus. Vol V: The Gifted Group at M1d-Llfe (Palo Alto, Callf.: Stancard Un1versity Pres8, 1959), pp. 187. 
SUGGESTED GUIDELINES FOR EARLY ENTRANCE PROGRAMS

The researoh seems to olearly indlcate that early entrance does not result in adrerse affects. In fact, aocelerants tend to equal or surpass their olassmates in terms of aoademio achlevement and general adjustment.

It 18 hoped that the following data will be helpful to any school system contemplating an early sohool admission program. These suggestions conoerning policles and prooedures take into aocount desoriptions, problems, and selection orlteria of early entrance programs found in the 11 terature as well as practioal experience in suoh a program.

It seems imperative that the early admission program be an integral part of the school progran. Early admission, in and of 1tself. does not insure that the academio needs of these students w111 be met. Instruct1 onel programing throughout the grades should be designed to meet the special needs of these chlldren, as well as other glfted chlidren who were not, because of age. eligible for early admittanoe. Th1s implies that personnel are avallable and definitely asalgned to follow through and continuously evaluate the plan. The progran must be designed and individ uallzed for each school distriot in terms of its personnel, resources, funds, and community setting. A modest beginning may avert problem experiences, and gradually lead to planned expansion. 
Chronological Age

Ch1ldren within six months of the minimum CA speolfied by the state may be thought of as posalble candidates for early admission to kindergarten. In most states this would apply to youngsters with $\mathrm{CA}^{\prime}$ 's between 4-3 to 4-8. Obrlousiy, by manlpulating the number of months beyond the minimum $C A$ to which a distriot will offor the privilege of early entrance, the school can control the number of children to be tested and orentually admitted.

Mental Ase

The minimum MA which schools have used in early entrance to kindergarten programs appears to range from 5-2 to 6-3. The Stanford-Binet Intelligence Test 18 typlcally employed to estimate this factor. Community soc10-economic status would probably play a major role in determining a MA out-oft point, if the school deolded to use one. In order to compete successfully the early entrant should at least equal the average kindergarte. chlld in a given distrlot in MA. Thus, the higher the intellectual norms of a given sohool system, the higher the minimum Ma limit would be. For example, say that 1t we decided that the child's MA upon entering first grade should at least equal the average Ma of beginning first graders for the district. If the average distriot IQ were assumed to be 114 , and the average $C A$ for beginning first grade is $6-2$, then the average beginning f1rst grade Ma for the district would be about $7-0$. Assuming, further, that mental 
growth is a linear function of IQ $x$ CA, then it would be a simple matter to caloulate expeoted first grade MA's for eariy admission to kindergarten applicants. Expected first grade MA rould equal IQ $x$ CA at the start of first grade, and for admittanoe, would need to equal or surpass the flgure of 7-0.

However, if the program were designed specifloally as a gifted program, then quite higher minimum standards would need to be employed depending upon the sohool systems unlque derinition of giftedness.

Stake has dereloped a table which prediots th1rd grade achlevenent of early-entranoe pup1ls when Stanford-Binet preschool mental ages and out-orf scores are used. 41 Table I, which is a reproduotion of the table presented by stake, was designed to help school administrators more efrlolently use ha measurements in selecting appropriate out-orf points. The educator oan oontrol the group of admitted pup1ls by adjusting the entrance requirements. Ralsing the requi rements will result in a higher achievIng sroup. However, since the correlation is far from perfect, no matter how high the requirement selected, some who enter early w11l not do superior work and some potentially high achlevers w111 not be adaltted early.

41 R. E. Stake, "Predioting Sucoess of the Early Starter" Oremien, (Norember, i960), pp. 32-34. 


\section{TABLE 1}

ACHIEVEMENT OF EARLY ENTRANCE PUPILS AT END OP THIRD GRADE, PREDICTED FROM PRESCHOOL BINET MENTAL AGES

Preachool

MA

5.2

5.3

5.4

5.5

5.6

5.7

5.8

5.9
Grade

Equivalent

4.1

4.2

4.3

4.3

4.4

4.4

4.5

4.5
Presohool

MA

6.0

6.1

6.2

6.3

6.4

6.5

6.6

6.7
Grade

Equivalent

4.6

4.6

4.7

4.7

4.8

4.8

4.9

4.9

Parental Request

Most schools linit tholr early entrance testing programs to those ohlldren whose parents speolfloally request this privilege. Such a program does not consider all posgible oandidates and may overlook many ohlldren who could suoceed and proflt from this experienoe. Other schools oharge fees for the examinations. Again, the administrator has oontrol over the program whioh can range from uniform ooverage of all ohildren or roduce the number of ohlldren through suoh selective devioes as only by parental request or oharging foes.

Phrstoal Health 
physical examination prior to the psyohological eraluation. It is usually the parents' responsiblilty rather than the sohool.

Social and Emotional Maturity

These are considered important variables in early admission programs. It is usually expected that the child rould rate at least equal to young-regular kindergartmers in both respects. The level of social and enotional maturity 18 typically judged by the psychologist during the course of his total evaluation, but some programs have the orinolpal or an experienoed kindergarten teacher interview the child and rate maturity in both these areas.

Phrsical size and Coordination

These do not seem to be viewed as major faotors by any of the early entrance programs in tems of selection oriteria.

$\underline{\text { Sex }}$

No differentiation 18 made in early admission standards on the basis of sex, nor does 1 appear that such a proposal warrants oonsideration. However, many prograns roport that more girls than bojs are accepted for early entrance.

Reporting the Deolsion

The manner of reporting to parents whother a ohild 18 acoepted or rejeoted for early attendance varies widely. Some schools communicate a verbal decision lmmediately after the test- 
1ng. Others send form letters and w11 disouss individual cases by appointment or over the telephone. The latter method has the advantage of arolding quiok judgments on certain borderline cases.

\section{Parent Intervier}

Many programs insist on a parent interviev to assess parental attitudes and obtain the chlld's developmentel history. If the perents show an understanding and acoeptanoe of their child, as well as a willingness to cooperate with the school in programs designed to help the ohild in his adjustment, then the application would show greater promise. A chlid would probably have a better chance to suciceed th such a farorable parental attitude.

\section{Retesting}

Most early admission prograns do not provide for retesting children originally deemed ineligible, although some programs allow for one or more fetests at parental request. Except in cases where professional sohool personnel request 1t, no provision for retesting seems to be a defensible position. This depends largely on the conviotions of the administrat1ve staff, adequate baoking by the Board of Eduoation, and general sohool-community relations. However, the school does have a professional obligation to examine and oonsider the findings of other private, professional praotitioners if the parents seek an additional evaluation from an independent source. 
Standardized Tests

All ourrent early entrance programs appear to employ psychologlsts to administer the 1960 Revised Stanford-Binet Intell1gence Test, Form L-M, to the applicants. Clinical observation and fudgment is the typlcal method of assessing soolal and emotional maturity, although in some oases the Vineland Soclal Matur1ty Soalo is given. Some supplement the1r findings with hunan flgure drawings, free hand drawings, reproductions of designs, number ganes, oral achiovement tests, or some other such techn1que.

Deolston

In most programs the psycholog1st recommends acceptance or rejeotion, but a comittee or an aduinistrator makes the final decision.

\section{Prta1 Perlod}

The majority of prograns have a trial period of attendance at sohool following eariy admission. This perlod ranges from two weeks to three months. Parents are told that one of the cond1t1ons of early admittance 18 that they w11l be asked to withdraw their ohild if he does not appear to benerit from it or should he make it diffloult for the group to profit from instruction. Nevertheless, the school hes the obligation to follor-up and assis these ohllaren throughout the trial perlod by working with the 
teachers and parents. Should a chlld have to be withdrawn from school in rare instanoes, the school should, through 1 ts special service personnel, maintain contaot with the parents and chlld in an attempt to prepare the child for school the following year.

Praotical experienoe suggests that a trial period is unnecessary. Existing early entrance programs rarely find it neoessary to have parents withdraw their ch1ld. Consequently, the trial pertod beoomes an extra burden on the on1ld and his parents. A trial pertod is usualiy added to the program at the request of conoerned kindergarten teaohers. Any ohlld can be remored from the sohool setting should the sohool experience not prove to be in the child's best interest without the designation of a trial period. In the parent conference prior to school entry this point could be omphasized in borderline cases that were accepted in the interest of proteating the onlld.

Hesearoh evidexoe suggests that the sohool should expeot no more than average achlevement and adjustment in kindergarten, although superiority in both these areas may ooour at this level depending upon the selection oriteria utilized for seleotion. If the flexible admission polloles are geared to the seleotion of g1fted joungsters, then placement in top classes throughout the1r schooling is most advisable.

PRESENT TESTS AVAILABLE AT THE PRESCHOOL LEVEL

All published tests whloh have been designed for preschool 
chlldren and are presently avallable to today's educator or psyohologist, require individual administration. This point may be verifled by cheoking general textbooks disoussing psyohologloal testing or referring to the latest edition of the Mentel Measurements Yearbook odited by Buros. 42

of the Individual tests speolfloally designed for the preschool level, the best known are probably the Merri1l-Palmer Soale and the Minnesota Presohool Scale. In addition, sereral other well-standardized and widely used individual tegts sultable for the preschool ages but extending elther downward into the infant level or upward into the sohool perlod are avallable. To mention a few, we might consider the Stanford-Binet, Kuhlman-Binet, Catell Infant Intell1gence Scale, Leiter Intermational Performance Soale, Gessell Developmental Sohedules, Oseretsky Tests of Motor Proflolency, and Vineland Soolal Maturity Soale. It was noted previously that the 1960 Revision of the Stanford-Binet is most typically employed in Barly Sohool Admission Programs as part of the 1ndividual evaluation ubon whioh ldentifloation and selection of oand1dates is based.

\section{TESTING PROBLEMS AT THE PREBCHOOL LEVEL}

Some of the testing problems encountered at the infant level overlep the preschool period. Such problems would involve

42 oscar K. Buros (Ed.), The S1xth Mental Measurements Yearbook, (H1ghland Park, N.J.: Gryphon Press, 1965) pp. 1765. 
motivation and interest, short attention span, and susceptibillty to fatigue. Moreover, presohool testing introduces probloms speoIflc to onlldren under five jears of age. Goodenough enumerates three ohlef characterlsties whioh she feels may interfere with sat1sfaotory Individual test performanee within the presehool range. 43 These are olassifled as shymess, dietractab111ty, and negativian. The strengeness of the phyaloal environment or the examiner may frighten the shs ohild. Such ohlidren way ory, want to remain with their paront, objeot to staying in the testing room or refuse to attexpt test 1tems. In many instances of this naturs It is necessary to allow the parent to romain in the exanination room to reassure the onlld in order to obtain some test results. The hyperaotivity and distraotability of sone presohoolers produoes a rurther problem. It 18 extrenely diffioult to test a ch11d who cannot remain seated and is moving about the room, handIlng materials, or asking questions about oountless unrelated or 1rrelevant matters. The negativistio ohl1d in the test setting may refuse to respond or perform and remaln sllent or unresponsive, fall to follow alrections, or resort to temper tantrums. The Minnesota Presohool Soale contalns rating soales for rocording the ohild's behav1or during the test with reference to each of the

43 Florense I. Goodenough, The Enotional Beharlor of Young Chlldren During Hental Tests", L. Juren11e Researoh. XIII, $(1929)$, pp. 204-219. 
three oharacteristics bretry desombed in the seotion. 44 Ixtreme manifestations of any of the types of beharior mentioned would probably result in the postponement of an individual evaluation.

Aslde from the behavioral attributes of the onlld whioh may oreate problems within the test setting, the development of satisfactory tests is muoh more diffloult at the prosohool level than for later years. Chlldren's experiences preoedlng sohool admission are quite varied, thexeby severely 11miting the number and quality of experienoes and materials from whioh the test constructor may derive suitable tegt 1tems. Reliabil1ty and val1alty indexes for tests are generally higher for older rather than younger subjects.

GROUP TESTING AND THE PRESCHOOL LEVEL

In discussing group tests in her book ent1+1ed psrohoLosloal Testing, Anastasl states:

The youngest age at which it has proven reasible to emplog group tests is the kindergarten and first grade 10ve1. At the presohool ages, Individual tosting 18 required in order to establish and maintain rapport, as well as to administer the oral and performanoe type of 1tems suitable for such children. By the age of 5 or 6 , however, it is possible to administer printed tests to smal1 groups of no more than 10 or 15 ohlldren. In such testing, the examiner must st111 give considerable individual attention to the subjects to make sure that

${ }^{44}$ Plorence I. Goodenough, Katherine M. Maurer, and M. J. Van Wegenen. Minnesota Preschool scales: Revised Manual (MInneapo11s: Educational Iest Buroau, 1940), pp. 127. 
directions are rollowed, ses that peges are tumed properly in the test booklets, and supervise other procedural detalls. With one or two assistant exampers, somewhat larger groups may bo tested if necessary. 45

Aoknowledging the problems posed at the presohool level both in teras of the behavioral attributes of the children and test construotion, it is not surprising to find that the $r$ is no presohool group test on the market today. This does not preclude the possibli1ty of developing a presohool group test, it merely assesses the most striking pitfalls. Like most things, when a pressing practiol need 18 delineated, the obstacles may be overoome to meet the crisis. That a need exists for a group soreening device in the area of carly admission to sohool seems evident. As noted previously, orer half the school systems in the oountry show interest or favor early entranoe to school in principle but relatively fow put it into practioe. Although many factore can be cited for the state of affalrs, the expenditure for professional personnel to administer individual tests to all presohool cand1dates is not a minor one. Even though school adnintration courses state theorectically that instructional needs and programing should override financlal conslderetions, the reverse appears strikingly apparent in most instances. A prosohool sroup screening instrument would provide any school the means to screen all of 1ts preschoolers at a minimum of cost and reserve individual evaluations for the rinal identification and selection of

\section{Anne Anastas1, Psychologleal Test1na, (New York:} Macmillan Co., 1954), p. 206. 
the 11mited number tentatively ploked on the basis of group te it. The following chapters deal with the construction and evaluation of a preschool group screening test designed to 1111 the vold noted in the reviow of the literature regarding early school adnission prograns and preschool testing. 
CHAPTER III

DESIGN

RATIONALE

Recognizing the host of problems involved in the development of a group test for the preschool level, procedures were systematically devised to counteract certain factors. The reader w111 readily detect various techniques atypical in present day test construction. These breaks with traditional test development appeared necessary in the formulation of a sroup test at the preschool level.

A cruolal element in any test setting is the establishment and maintenance of rapport. Several measures were taken to meet this need. Upon arrival at the test session, the examiner or test monitor briefly chatted with each child individually to set him at ease. Next, a colorful number tag was pinned on the child, since children like to be given things at this age level. Prior to the formal testing period the children were lead in group play activities which involved singing, body movements, finger play, and other sultable games for this age level to relax them and satisfy their need for motor aotivity. The test was divided into two parts of twenty-five items each to provide another forced rest and activity period in the middie of the test session, since 
preschoolers are unacoustomed to an extended period of formal structure and are easily susceptible to fatigue.

To motivate and maintain the ohildrens' interest in the test, the test items were not presented in order of their diffioulty or disoriminating power. It was felt that preschoolers would find new momentum and renewed motivation by progressing through a test altemating between a sequence of easy and more diffioult items. At this age level the manner of presentation and attitude or the examiner plays an important role in keeping youngsters encouraged and reassured. To this end several statements were inoluded in the administration directions whioh were Intended to enoourage and reinforce the test behavior of ohlidren.

When more than fifteen ch1ldren were tested a monltor was present with the examiner for further management and control purposes as well as to assist with administrative prooedural detalls, such as, checking individual performance on sample items or assist ing some ohlldren in turning pages. However, the major role of such an assistant was the reoording of the test behavior of ind1vidual children to supplement the objeotive test results. In this manner the test results can be interpreted in a more intelligible and meaningrul fashion.

In an attenpt to reduoe hyperactivity or distractab111ty on the part of ohildren in the classroom testing setting, instructional materials and toys were placed in cablnets or covered with 
drapes to eliminate stimulating or distracting 1 toms from the physioal environment. Conversely, to stimulate and foous the attention of the ohlidren on the test, only one test item was presented per page. Equaliy important, each test 1 tem was printed on a different oolored page contrasting it from adjacent pages, Each Item was timed but the timing was 11 beral onough to permit most youngsters to complete the 1 tem.

The different colored pages 11kewlse facllitated admin1stration by acting as a check that all onlldren we re on the oorrect page. Those children haring diffloulty turning pages or following directions could be easily located and assisted by surveying the group before the direotions for the next 1 tem were given. FollowIng each 1tem the ohlldren were reminded to turn the page to form a hablt by routine. Care was taken to speak slowly and distinctiy In a clear, natural, pleasant voloe with ample repetition. Sample 1tems were provided prior to rarious sequences of test 1 tems to offer speolfio help in following direotions.

The ch1ldren were directed to respond to the multiple cholce items by marking an $X$ on the correct ploture. Howerer, any type of mark produced by the chlldren was accepted and scored as correct provided the marked plcture was the oorrect cholce. This was done due to the wide variance in motor coordination at this level.

Initative behavior or copying 18 typical at the presohool 
level since it is a major avenue to leaming. In the test setting measures had to be taken to preclude this beherior. Th1s was accomplished by both or elther providing adequate spaoing or placing oardboard dividers between onlldren.

Prior to the group testing, parents were reminded to attend to their ohild's lavatory needs. It was understood that no parents would be allowed in the group testing room under any circumstanoes. This wos done to prevent future coaohing by parents with younger siblings or other youngsters through parent-parent sharing information get-togethers.

The ease with whlch the ohlld could be separated from his parent in order to enter the group testing room was taken as one indication of his emotional maturity. If initial attempts by parent and examiner to have the ohlid enter the testing room were unsuccessful, and if the chlld contlnued to cause a disturbance through his orylng or temper tantrum, the parent was expeoted to withdraw the child from that soheduled session. This was done to arold causing other children to feel uneasy and lead to a possible mess reaction of insecurity. The ohlldren who had separation anxlety problems were later seen in smaller group session.

Test sheets measured in size $51 / 2$ inches by 8 inches. They were fastened together at the top (narrow width) rather than on the slde so chlldren could place their booklet in a comfortable position without thelr handedness becoming a problem. 


\section{ITEM SELECTION}

Prior to the beginning of the 1964-65 sohool year, elghty candidates for early admission to sohool ranging in age from four years-six months to four years-elght months were evaluated individ ually. Each child was administered the 1960 Revision of the Stanford-Binet Intel11genoe Test. In addition, depending on the preference of the examining psychologlst, the youngsters were asked to draw a man, IInish an incomplete ploture of a man, print their name, and reoognize letters and numbers on the Wide Range Achlevement Test. Evidenoe of social, emotional and physical maturity was noted through observation prior to and during the evaluation.

After the indiridual Identification and selection of those to be adnitted early to kindergarten on the basis of pre-determined oriteria was completed, each sub-test 1 tem on the aforementioned individual test procedures was analyzed to determine its ablilty to disoriminate between those youngsters acoepted for early entrance and those rejected. Since no child under a minimum mental age of fire years-ten months was accepted, the subsequent discrimination indexes may be thought of as separating youngsters (CA 4-6 to 4-8) above and below MA 5-10 (IQ 126 and above).

On the Stanford-B1net, Porm L-Y, all subtest 1 tems between Level IV-6 and Level VII were analyzed to determine their 
discriminating power. The upper and lower twenty-seven percent of the elghty youngster total plovided o omparison between the top twenty-one ohliaren (MA 5-10 to 7-1) and the lower twenty-one children (MA 3-7 to 4-11). Table II provides a 11sting of the subtests on the Stanford-Blnet which appeared most userul in the development of the group test in terms of their level of alfficulty and discrimination value.

\section{TABLE II}

\section{ITEM ANALYSIS DATA ON STANFORD-BINET} COMPARING PRESCHOOLERS WHO WERE ADMITTED EARLY AND REJECTED FOR KINDERGARTEN PLACEMENT

\begin{tabular}{|c|c|c|c|c|c|c|c|c|}
\hline \multirow[b]{2}{*}{ Level } & \multirow[b]{2}{*}{ Item } & \multirow[b]{2}{*}{ Deseriotion } & \multicolumn{2}{|c|}{ Jpper 27\% } & \multicolumn{2}{|c|}{ Lover 27} & \multirow[b]{2}{*}{$\mathbf{r}$} & \multirow[b]{2}{*}{ Diff. } \\
\hline & & & $N$ & 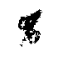 & $\mathbf{N}$ & x & & \\
\hline$\nabla$ & 4 & Copying square & 15 & 71 & 3 & 14 & .58 & 43 \\
\hline VI & 1 & Vocabulary & 20 & 95 & 2 & 10 & .85 & 52 \\
\hline VI & 2 & Differenoe & 15 & 71 & 1 & 5 & .68 & 38 \\
\hline VI & 3 & Mut1lated plotures & 15 & 71 & 3 & 14 & .58 & 43 \\
\hline VI & 4 & Number ooncepts & 15 & 71 & 1 & 5 & .68 & 38 \\
\hline VI & 5 & Opposite analagies & 16 & 76 & 2 & 10 & .67 & 43 \\
\hline VI & 6 & Mazes & 19 & 90 & 6 & 29 & .63 & 60 \\
\hline VII & 5 & Opposite analagies & 14 & 67 & 0 & 0 & .79 & 33 \\
\hline
\end{tabular}


power and average diffloulty between early entrants and those not accepted, thirty-four 1tems vere sapted for the inltial development of the sroup test.

S1xty-seven peroent of the upper group were able to print three or more letters of thelr first name as opposed to only fourteen percent of the lower group. The table of Flanagan $x^{\prime} s$ ylelded a correlation of .53 between the upper 27 peroent and lower 27 percent of the group in their ability to print three or more letters. On the basis of the information, printing sk111 provided another test 1tem for the preschool soreening test.

Due to the difference in the type of individual tests administered by the psychologists, only nine of the top twenty-one chlldren were asked to draw a person. For oomparison purposes, nine of the lower twenty-one joungsters were chosen at random. The drawings were soored on the basts of the Goodenough Draw-A-Man Test. All of the nine chlldren in the upper groun achioved a raw score of flve or morv, whereas only flfty-six percent of the lower nine youngsters made a similar scors. On the basis of the data, draving man was ut111zed as one item on the group test.

S1x of the top twenty-one ohlldren had recelved an abbreviated form of the W1de Range Achlovement Test. For comparison purposes data regarding $s 1 x$ of the lower twenty-one children was randomly selected. All six in the high group recognized letters $(A-B-O-S-E-R-T-H)$ and numbers $(3-5-6)$ but none in the low group. 
Recognition of numbers and letters provided an additional six tryout items for the group test.

During the flrst week of school in September, 1964, a kindergarten olass was administered the Metropol 1 tan Readiness lest, Form S. Plve of the pup113 tested were early entrants. The remalnirg twenty-f1ve students were ranked in terms of their percentile soores and the lower flve were compared with the early ontrants on one hundred subtest 1tems. Only flve of the 1tems (rest 1, Word Meaning, Items 7 and 12; Test 3, Information, Item 14; Tes: 4, Matohing. Item 16; and Test 5, Numbers, Item 16) demonstra ted a suffiolent degree of disorimination for molusion in the group tegt on a trial basis. It should be noted that the data on the test were corparing early entrants and regularly adnitted, older ohlldren, whereas previous comparlsons were between high and low rankings of early entrance candidates.

The foregolng teohnlqus ylelded forty-seven test ltams derived on an empificel basis from several individual and one group test. These itens rere then adepted for group presentation. An additional twenty-two 1tems developed by the invest1gator wers prepared jielding a total of sixty-nine test 1tems for initial inclusion in the experimental form of the preschool group screening test.

In an effort to explain how the disoriminating subtest 1tems on individual tests were transformed for presentation in the 
group test, the following examples are offered.

Sample 1. Vocabulary 1tems on the Stanford-B1net (Level VI, Item 1) require verbal presentation and an oral response. Each vocabulary 1 tem or word was reproduced in plotorlal form and three distracting outline drawings added. The reader will recogn1ze this format as simliar to many ploture vooabulary tests used for Individual administration. For group testing purposes the testee was asked to mark the plcture of the word presented orally while looking at a set of four plctures.

Sample 2. On the subtest involving multilated pletures on the Stenford-B1net (Level VI, Item 3) the child 18 asked to verbally Indicate what $1 \mathrm{~s}$ gone in the ploture. On the group test a multilated ploture was deploted at the top of the page and beneath 1t were four possible cholces of the missing part. The child was instruoted to mark the ploture of the part that was not in the large (mult1lated) ploture at the top of the page.

Sample 3. Number concepts on the Stanford-Binet (Level VI, Item 4) require the subject to place a certain number of blooks on a sheet of paper. On the group test the chlld viewed a page with twelve squares on $1 t$ and was asked to mark a prescribed number of squares.

In this manner 1tems were derived on an emplrical basis from several individual tests and transformed for inclusi on in the group test. It was then necessary to determine if these trans- 
formed 1 tems sufficiently retalned their discriminating power via group presentation.

The initial group instrument of sixty-nine items was administered to two groups of children. The flrst group included seventy-two kindergartion youngsters from an all white, uppermiddle-olass suburban sohool. Thelr ages manged from five yearsthree months to six years-two months. The sesond group oonsisted primarily of a white, upper-midale class sample of elghteen preschoolers enrolled in a private nursery school. Their ohronological ages ranged from four years-no months to f1ve years-no months. On the basis of the preliminary testing in these two groups, especially at the nursery sohool level, the initial form of the Preschool Group Soreening Test of Early Entranoe to Kindergarten Potentlal1ty was revised to the present fifty item test ourrently being used in this researoh paper.

Item analysis of the kindergarten data indicated that more than half of the tryout 1 tems were too easy and lacked disoriminatIng power at the five year level. Tetrachorlo correlations with the oriterion dichotomized at the median were utilized to determine discriminating indexes. Some 1 tems were too difficult even at the kindergarten level, indioating that they would be of no value at the preschool level.

Table III shows the summary of the 1 tem analysis data for the nursery sohool ohildren in the pllot study in terms of the 
fifty 1tems chosen for the present forn of the test. The upper and lower fifty percent of children were compared to obtain item disorimination and item diffloulty values. The resulting group test contains twenty-six items with a disoriminating power varyIng between . 20 and .80 , elght items between .10 and .19 , and sixteen 1tems with no observable disorimination value. The items with a discriminating index between .10 and .19 rere inoluded on the theory that with a larger and broader sample their disoriminating ability may increase. The sixteen non-disoriminating items were inoluded for the above reason but also for motivational purposes. One of the reasons olted in the literature to explain why no group preschool test had been developed was the difflculty in establishing and maintaining rapport as well as devising sultable items for administration at this level. Thus, it seemed reasonable to sprinkle easy, although non-discriminating 1 tems throughout the test to ease the testing situation for the children. 


\section{TABLE III}

PREQUENCY DISTRIBUTIONS OF ITEM ANALYSIS

DATA FOR DISCRIMINATION AND DIPPICULTY

INDEXES ON FIPTY TRY-OUT ITEMS IN ORIGINAL

GROUP TEST WITE NURSERY SCHOOL CHILDBEN

Values

Diserimination

Index

Diffioulty

Index

$.90-.99$

0

13

$.80-.89$

3

5

$.70-.79$

6

5

$.60-.69$

1

11

$.50-.59$

7

5

$.40-.49$

2

1

$.30-.39$

3

3

$.20-.29$

4

2

$.10-.19$

8

4

$0 \quad-.09$

16

1

Total

50

50

Three observers (a researcher and two kindergarten teachers we re present during the pllot testing to subjectively evaluate the test administration. On the basis of their suggestions the 
following modifloations are present in the group test or manual.

1. More adequate spacing of chlldren or further ut111zation of dividers between ohlldren was recommended to counteraot imitative behavior (copjing).

2. More sample 1 tems rere employed prior to various 1 tem sequences in the test.

3. The test was alvided into two booklets rather than one to provide a natural break in the testing session because presohool ohlidren find it diffioult to remain attentive for a sustained period of time. Likewise, two booklets seomed to be more advantageous than three booklets since the latter approach tends to make the test session too lengthy even though more breaks are provided.

4. Easy and more difficult 1tems sequences have been alternated throughout the test for motivational and reinforoement purposes.

5. All 1 tems previously given fifteen seconds for completion were reduced to ten seoonds since the latter time interval seemed sufficient for all ohildren to complete the 1 tems.

Two other areas in whioh the investigator antlolpated possible problems did not eventuate. The observers indicated unanimously that the large size of the groups and the turning of pages did not appear to be problens. 


\section{TEST MATERIALS}

The Preschool Group Soreenling Tegt of Early Entrance to Kindergarten Potentiality was designed for group administration by school personnel other than tralned psychometriolans or psycholog1sts. An attempt was made to develop a tost that would be useful in detecting those ohildren who were likely oandidates for early admission to kindergarten. In addition, it provides an estimate of intell1gence for children ranging in chronological age from four jears-81x months to four jears-elght wonths. The sroup test is not intended to take the place of a more comprehensive Individual assessment, rather to reserve ind1vidual, time-consumIng, evaluations for the $11 \mathrm{mited}$ number of most $11 \mathrm{kelg}$ oandidates for early school admission. In this menner the group test supplements individual testing by providing a soreening devioe prior to the indiscriminate use of Individual tosts and professional time.

The materials required for adminlstration of the group test consist of the following:

1. An examiner's manual (Appendix A);

2. A set of two record booklets per testee (Append1x B);

3. A record form for sooring a subject's responses (Appendix C).

The fifty item group test 18 divided into two separate booklets of twenty-f1ve 1 tems each plus demonstration or samplo 
1tems. Part I 1nvolves the exolusire use of multiple cholce 1tems, wherein the child merely marks his cholce with pencil to ind 1cate his answer. Part II includes copying, drewing and printing items as well as the multiple oholce type.

Table IV IIsts the major categorles of items in the group test in 1 ts present fom and indicates the raw score points that it is possibls to achiove in the test.

\section{TABLE IV}

TYPE AND NUMBER OF ITEMS INCLUDED IN

PRESCHOOL GROUP TEST

\begin{tabular}{lcc}
\hline \multicolumn{1}{c}{ Category } & $\begin{array}{c}\text { Number of } \\
\text { Test Items }\end{array}$ & $\begin{array}{c}\text { Possiblo } \\
\text { Points }\end{array}$ \\
\hline Draw-a-man & 1 & 16 \\
Numbers (recognition, concepts, printing) & 11 & 15 \\
Ploture vocabulary & 11 & 13 \\
Letters (reoognition and printing) & 5 & 10 \\
Plcture description & 7 & 9 \\
Relationships (size, space, direotion, & 7 & 8 \\
Multilated pictures & 5 & 6 \\
Copying designs & 3 & 4 \\
\hline \multicolumn{1}{c}{ Total } & 50 & 81 \\
\hline
\end{tabular}


Directions and Instructions are given orally by the examiner while subjeots soan a single page on which are represented four or more possible oholoes or answers. The subject responds to the examiner's instructions by marking one of the line drawings on the page. In some instances the ohlldren are asked to respond by copying a design, printing their name, or drawing a ploture.

Each page of the booklet measures $51 / 2$ Inches by 8 inches and contains only one test 1tem. Eaoh booklet is stapled at the top (the smallest width) so the subjeot can position the booklet according to his handedness. The pages of the booklet alternate with four different oolors. This format was followed to help stimuzate the subjeot and assist the examiner in determining that the subjects were on the oorrect page.

All 1tems have specific time 11mits but the time interval 13 sufficient for the majorlty of subjects to complete the assigned tasks. Total administration timo is approxlmately one hour which includes an activity perlod prior to and in the midale of the test. Scoring of the group test averages about six minutes per test.

Intermittent motivational statements and verbal reinforoement of the subjects' behavior are bullt into the test directions, Moroover, test 1 tems are not presented in order of difficulty, rather they are arranged in a pattern of altemating easy and harder sequences to motivate and reinforoe a subject's performon. 
The Preschool Group Sereening Test of Barly Entranoe to Kindergarten potent1el1ty has the following features:

1. It is a userul screening device spec1flealiy developed for presohool programs.

2. Preschool groups of thirty or more ohlldren oan eas1ly be accomodated in one testing session.

3. The test sares time so compared with individualiy adminlstered tests, yet offers a val1d and rellable test at the presohool level.

4. It is sultable for average, above averace and superiod levels of Intelieot.

5. Presohoolers nost $11 \mathrm{kely}$ to be accepted for early adrisaion to school are easily detected.

6. Norms are presented in terms of atandard soore deviation IQ's.

7. Gut-arf polnts for early entrance to kindergarten are suggested but users are encouraged to supplement this data with community and school data.

8. Manual contalns clear, conolse directlons for adminlstration and sooring and does not require a trained specialist. 
9. Items are meaningful. to oh1ldren four years-B1x months to four years-eight months of age.

10. Responsea are ormpletely non-verbal.

11. Sooring is simple and primarily objective.

12. Each test item is printed on a separate and difrepent colored page.

13. Clear, bold ine dravings are presented devold of fine detall to reduce flgure ground problens of pereeption.

14. Ilustrations ara appropriate to age level of subjects

15. Items are arranged in alternating sequenoes of disorimination and dirfioulty to provide continued interest, motivation and relnforcement. 
CHAPTER IV

METHOD

THE SAMPLE

The sample explored in the standardization of the Preschool Group Soreening Test of Early Sohool Entranoe Potentiality consist ed of presohool ohildren within School Distriot 68, Skokie,

Illinols. This sohool distriot was selected for sereral reasons:

(1) D1atriot 68 had had experience in conducting and matntaining an early entrance program orer a five year period;

(2) The adninistration of the district not only expressed a w1Ilngness to partiolpate in the study but offered eneouragement and assistance in terus of persomnel, resouroes, and rao111t1es; and

(3) The distriot was conveniently located and eas11y accessible to the investigator.

Skokle, as a village, is the largest In the United States. Polltioally, It is part of the 13th Congressional District of IIIInols. Acoording to the 1960 census, this Congressionel D1strict ranked firgt in the nation in terms of family income (median $\$ 9,389$ ), highest eduoation (median 12.6 years), and least unemplosment ( 1.6 percent).

Soclally, it appears to be inhabited mainly by white, 
upper-middle olass ramilies consisting primarily of professionals, managerlal and exeoutive persons, and sk11led workers with relatively high inoome. Approximately sixty percent of the families are Jewlsh. The majority of the adults in the community are college graduates. However, there are fringe areas wherein some fam1lies would be olassifled soclo-economically as lower-middle class or midale olass, but these familles are usually striving to conpete with or become uppermidale olass.

Skokle is part of N1Ies Townshlp which Is looated directly northwest of Chloago. Sohool Distrlot 68, Old Orohard, is one of five elementary sohool districts serving the village of skokle which has a population of about 68,000 . Sohool D1striot 68 serves the northern seation of the viliage of skokie. This northern suburb of Chloago is surrounded by Branston to the East, Lineolnwood to the South, N1les and Morton Grove to the West, and Wilwette and Golf to the North.

School Distriot 68 has adhered to the kindergarten through elghth grade plan of elementary sohool organization with an enroll. ment of about 4200 pupils. Repetition of grade 18 rather unoommon The arerage IQ of the pup11s, based upon the Lorge-Thomdike Group Intell1senoe Test is approximately 115.

Pre-school ohildren between the ages of four years-six months and four jears-elght months who would miss the rigld chronologloal out-orf point set by the state by from one to ninety 
days served as the sample. It was eatimated on the besis of infor mal census data that approximately 100 presohoolers would fall in this category, that is, their fifth birthday would be on or between December 2, 1965 and February 28, 1966. Although spec1al efforts were made in the form of newspaper releases, Parent Teacher Association bulletins, and notioes sent home with pupils, all potential candidates for early entrance to kindergarten were not involved in the study. A rariety of reasons acoounted for this: (1) oonfliot between the testing sohedule and parent vacation plans; (2) unaware of the early entranoe program; (3) informed but not interested.

One hundred and two ohlldren were reglstered for consideration in the Early Admission to School Program. Of these, twelve were unable to keep thelr appointments for both the group and Individual evaluations. Thus, the sample Inoluded ninety children for the purposes of the present investigation. Table V shows the distribution of the sample by birthdate and by sex. The sample seeras to be balanced about evenly between boys and girls with mote oeses representing December-bom ohildren than January or Pebruary blrthdates. Since parents of older on11dren or those oloser to the arbitrary out-off date for regular ontrance set by the state are more anxious to have their onlidren attend school and the test will probably be used more widely with such ohlidren, this is oonsidered to be satisfactory. 
TABLE V

SIZE OP SAMPLE BY BIRTHDATE AND SEX

B1xthdate Male Fomale Total

$\begin{array}{llll}\text { December } & 18 & 22 & 40\end{array}$

\begin{tabular}{llll} 
January & 12 & 14 & 26 \\
February & 12 & 12 & 24 \\
\hline Total & 42 & 48 & 90
\end{tabular}

\section{GENERAL PROCEDURES}

Beginning in the spring of 1965 several newspaper releases regarding the Early Entrance to KIndergarten Program were printed In the $100 a 1$ community papers. Thls was followed by a Parent Teacher Assoolation Bulletin and notices sent home with children who had youngex presohool siblings to enoourage parents to register their ohlidron in adranoe for the program. At a group meeting In July 1965, proceded by a letter, parents were g1ven both group and indiridual evaluation appointments for their ohildren.

The Presohool Soreening Groun Test of Early Entrance to Kindergarten Potent1aliby was administered to all registered presohool candidates in separate groups of 15 to 30 youngsters on July 29 and 30, 1965. A group test make-up examinatior was held on August 16, 1965 for 14 youngsters. Individual evaluations of 
all youngsters, 1nvolving ratings of behavior and emotional maturity and the administration of the Stanford-Binet, Form L-M, Wide Bange Achlevement Test, and Draw-A-Man Test, we re soheduled during the first two weeks of August, 1965. In the group setting youngsters were given a test number wh1le the1r names were ut11ized in the Individual testing. This was necessary because the present investigator administered and sccred all the group tests and examined about half of the candidates on an Individual basis. A second psyohologist was employed to assist with the individual evaluations of the remaining youngsters.

Prior to the procedures disoussed above the group test pras administered to s1xty-seven youngsters on May 31 , and June 3 , 1965. Twenty of these youngsters were later involved in the July testing whion provided the first test-retest rellabli1ty index for an elght week interval.

A second group test-retest measure involved fourteen othey presohoolers of the ninety candidates for early entranoe. The test was administered on August 28, 1965 allowing a time lapse of four weeks. Since none of these preschoolers were acoepted for early entranoe to kindergarten, the partlolpants were composed largels of volunteers.

Although the majority of 1tems on the group test are objective, flve ltoms (oopying, printing and drawing) involve subjeotivity in sooring. One of the purposes for the development 
of the group test was to allow non-speo1al1sts to administer and soore it to reduce costs involved in early admission programs. Thus, soorer rellab1l1ty was cheoked between psychologlst, teaoher, clext, and housewife on 38 cases of the sample.

The majority of Early Admission Programs reported in the 11terature Indicate that the 1960 Bevision of the Stanford-Binet Indiridusl Intellisence Test is emplojed as the primary instrument to assess intelleotual ability. Aoknowledging this, the Stanford-Binet was used as a model in tems of the group test construotion and as one major oriterion to demonstrate oontent vallalty and conourrent validity respectively.

\section{GROUP TEST PROCEDURES}

Parents of preschool chlldren residing within the distriot were infited to have their child attend a group testing session at the elementary sohool nearest their residenoe if their ch1ld's rifth b1rthday was on or between December 2, 1965 and February 28, 1966. At the group session parents were asked to complete a brief information sheet and an identification number tag was pinned on thelr child. The group of chlldren were then separated frow their parente and taken to a first grade room by a kindergarten teaoher to establish rapport, play games, and have an aotivity period prior to the formal and atruotured testing session. After making a fow brief comments to the parents the examiner entered the testing roon and distributed primary penolls 
and booklets, numbering then to correspond with each oh1ld's Idantifioation tag.

Part I of the test was then administered by the examiner but the kindergarten teacher remalned in the room for management and control purposes, but, most important, to observe and keep written records regarding the bohavior of individual ohlldren. When Part I was completed the teacher held another activity sessIon while the examiner collected the oompleted booklets and distributed and numbered Part II. Upon the completion of the group testing the chlldren were returned to thelr parents who were walting in another wing of the sohool bullding.

Regaraless of the size of the groups the total testing time including the two activity periods was approximately one hour. The initial greeting of parents and children averaged an additional firteen minutes.

Flfteen or less chlldren could eas1ly be handled adequateif by one person. An additional person was required as the numbed of subjects increased malniy for purooses of recording the beharlor of varlous chlldren and assisting ohlidren farthest from the examiner in terms of administrative procedural deta1ls.

The activity perlods are felt to be highly desirous and necessary at this age level. Although many of the ohlidren may have experienced a nursery sohool setting, it 18 not easy for presohoolers to enter a strange phrstoal and soolal envi ronment. 
For this reason a desoription of the actipity periods seems pronted.

When first seated in the room pxior to the group test, the teacher would sing famillar songs with the ohildren to put them at ease. Marr Had A Little Lamb and Jingle Bells seemed to be the most popular with the children. While singing the teacher rould enoourage movement on the part of the chlldren. For instance, the chlldren were akked to protend thelr hands were bells and to shake then while singing Jingle Bells.

Following this the ohlidren were asked to stand behind thelr desks and were taught the song. Head, Shoulders, Knees and Toes, starting slowly and progressively becoming faster. The chlldren join in quiokly and leam to point while singing or saythe words. The words are:

"Herd, shoulders, knees and toes, knees and toes Head, shoulders, knees and toes, knees and toes and Eyes and ears and mouth and nose, Head, shoulders, knees and toes, knees and toes."

The chlidren also appeared to enjoy ringer play: "I have ten 11ttle fingers and they all belong to me. I can make them do things Would gou l1ke to see?

I can shut them together or make them all hide I oan make them jump high 
I can make them jump $10 \%$.

I cen fold them up quiokly and hold them just so."

During the break after part I testing some of the aforeraentloned actirities oould be repeated. Other laeas rould be for the chlldron to pretend they were a rocket ship. The children crouch and oount backwards from ten and after zero say, "Blast offn, and all jump up. Or, they might hop in place like bunny, mun in place, or clap the1r hands fest and loud, soft and slow or varlations of these. Another activity might be the "Hokey Pokey" but Instead of using left and right, have the ohlidren put both hands in, both reot in, head in, and mole body in the o1role of children.

Lastiy, an actiolty which is excellent alreotly before the testing begins 18 to have all the oh11dren make a big happy smile through the reoltation of the following poem:

"I have something in my pooket

It belongs across uy faoe

I keep it very olose to ne

In a very speolal plaoe.

I knov you'11 never guess it

If you guess long, long wh1le.

So I'II take 1 t but and put 1 t on

It's a great b18 happy mile." 
36

Plate 1 illustrates the testing setting through the prosentation of two photographs. The first picture deplots a kindergarter teacher leading the group activity period while the second photo shows the actual test administration.

Undoubtedly an Imaginative teacher could think of several other activities that would be stable at this age level. The content or type of activity 18 not so Important as long as it fits the age range. The establishment of rapport and security that results from such activities is of primary concern. 


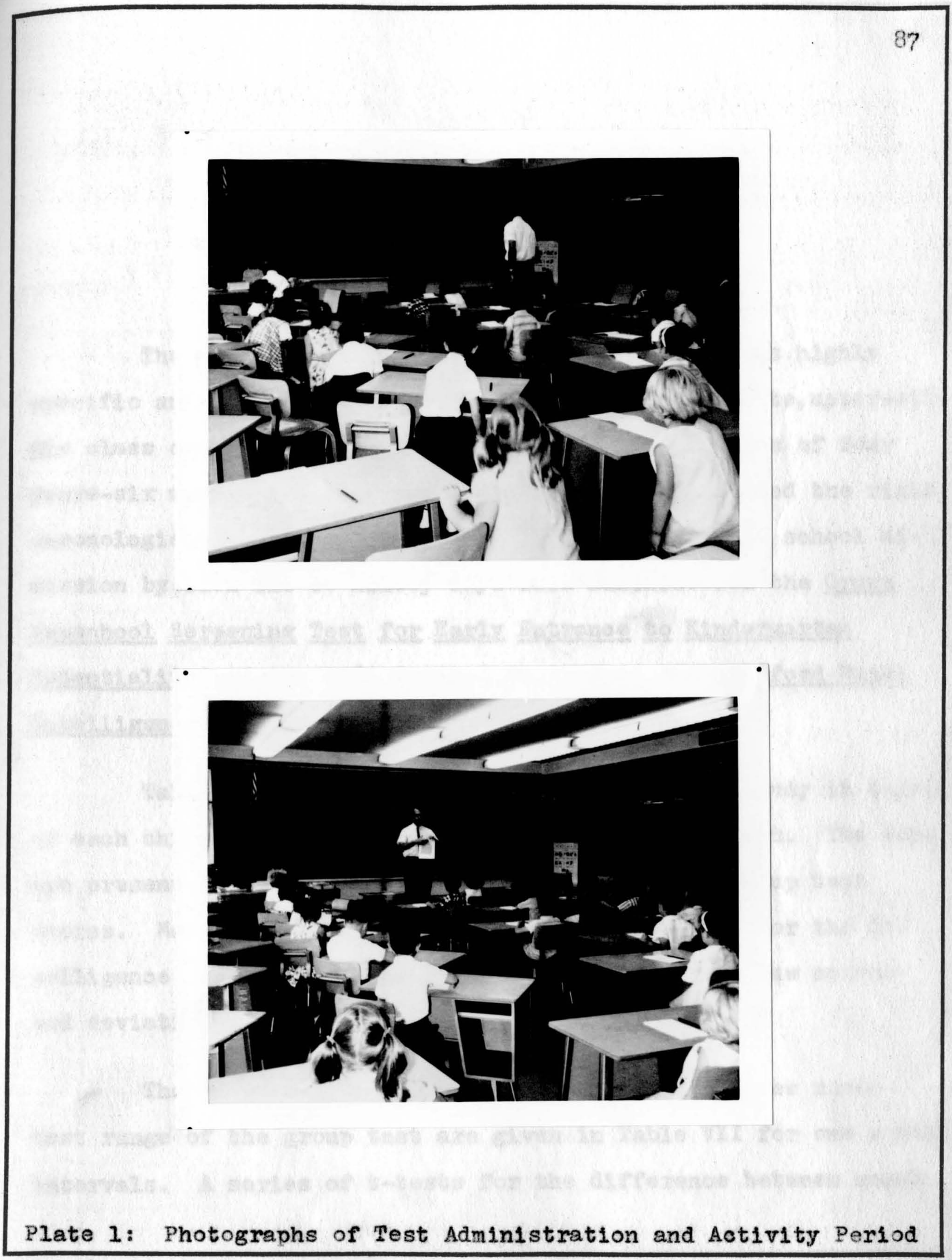




\section{CRAPTER V}

\section{RESULTS \\ GROUP TEST NORHATIVE DATA}

The samplo used for establishlng the norms was highly specifle and restrieted to children realding in a mite, upper-middie class communlty. NInety chlidren between the ages of four years-81x months and four jears-e1ght wonths wo missed the rigld chronologloal age date set by the state for automatio school admiseion by from one to ninety days were administered the Group Preschool Soreonins Teat for Enrly Entrynoe to Kindercerton Potentiality and the 1960 Rerlsed Edition of the Stanford-Binet Inte111romse Test.

Table VI presents the basto results of the study in terms of each ohlid's soore on the group and Individual test. The data are presented in descending order on the basis of group test soores. Means and standard devlations are reported for the intelligenoe quotients on the Individual test and for rar soores and deviation IQ's on the erroup test.

The distribution of raw soores within the three month test range of the sroup test are glven in Pable VII for one month intervals. A serles of t-tests for the difference between means 
TABLE VI

COMPARISON OF GROUP AND INDIVIDUAL TEST RESULTS

PHESCROOL GROUP SCREENING TEST

Ch12d's

Number
Rav Soore

67

63

61

59

57

50

49

49

48

46

46

45

45

43

42

42

40

40

40

40

39

38

37

37

37

37

37

36

35

35

35

35

34

34

34

34

34
Deviation IQ

Stanford-Binet, Forn $L-M, I Q$
147

124

135

126

132

139

132

118

139

111

126

122

116

138

116

144

116

132

153

114

113

130

134

94

107

116

122

114

130

114

10 ?

111

128

109

101

103

122

131

89

34 


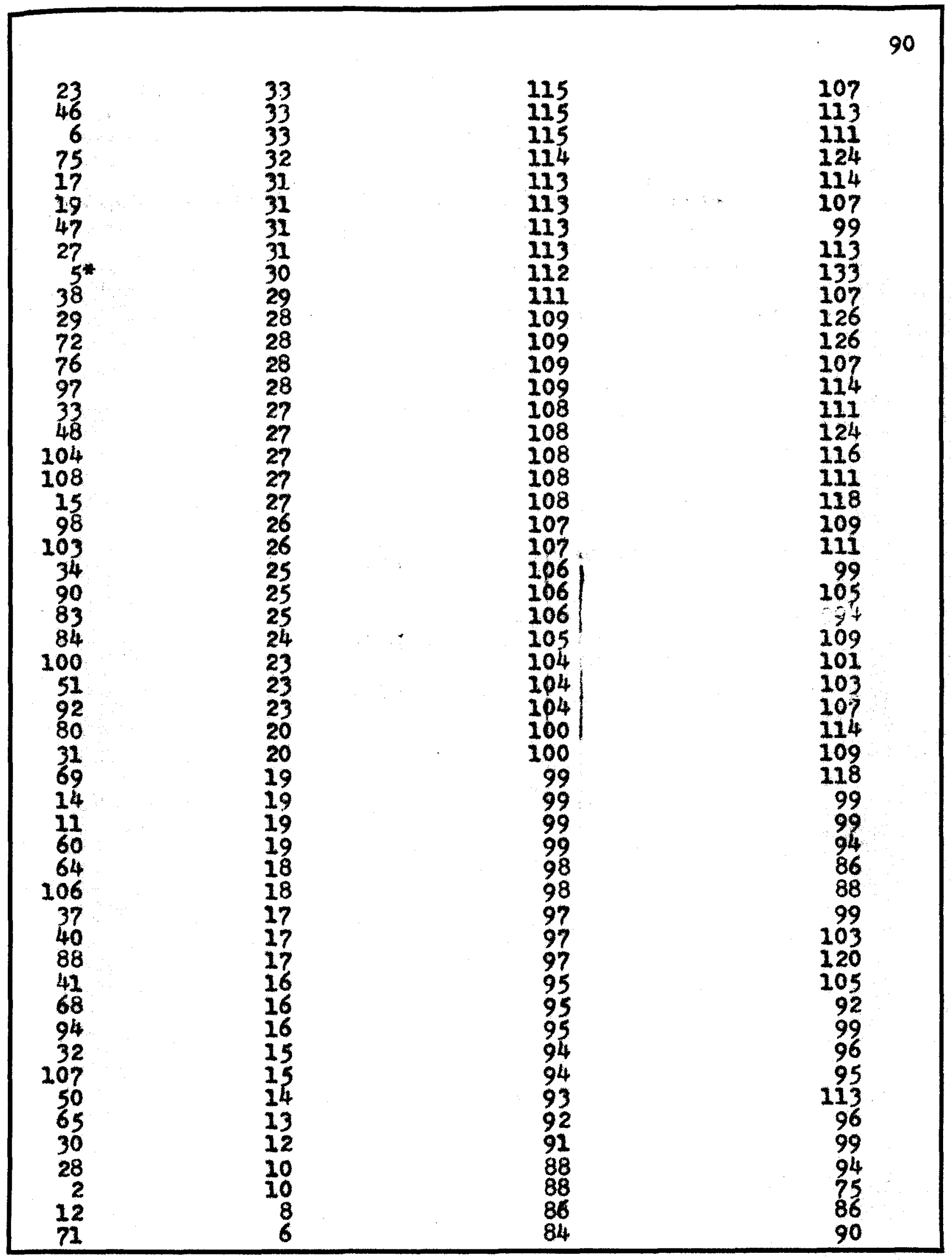


Mean

S.D.
31.14

12.89
113.00

15.00
112.81 14.96

* - asterisk denotes those ohildren who were acoepted in early entrance program. 
TABLE VII

PREQUENCY DISTRIBUTIONS OP RAW SCORES

POR EACH AGE GROUP IN SAMPLE

\begin{tabular}{|c|c|c|c|c|}
\hline \multirow{2}{*}{$\begin{array}{l}\text { Ray } \\
\text { Soore }\end{array}$} & \multicolumn{3}{|c|}{ Ase } & \multirow[b]{2}{*}{ Total } \\
\hline & $\begin{array}{c}\text { Deoenber } \\
4-8\end{array}$ & $\underset{4-7}{\operatorname{Januaxy}}$ & Pobimaxy & \\
\hline $75-79$ & & & & 0 \\
\hline $70-74$ & & & & 0 \\
\hline $65-69$ & 1 & & & 1 \\
\hline $60-64$ & 2 & & & 2 \\
\hline $55-59$ & 1 & & 1 & 2 \\
\hline $50-54$ & 1 & & 1 & 2 \\
\hline $45-49$ & 2 & 4 & 1 & 7 \\
\hline $40-44$ & 4 & 2 & 1 & 7 \\
\hline $35-39$ & 5 & 2 & 5 & 12 \\
\hline $30-34$ & 9 & 4 & 2 & 15 \\
\hline $25-29$ & 5 & 6 & 4 & 15 \\
\hline $20-24$ & 0 & 4 & 2 & 6 \\
\hline $15-19$ & 6 & 3 & 5 & 14 \\
\hline $10-14$ & 3 & 1 & 1 & 5 \\
\hline $5-9$ & 1 & & 1 & 2 \\
\hline $0-4$ & & & & 0 \\
\hline Total & 40 & 26 & 24 & 90 \\
\hline Mean & 32.83 & 29.96 & 29.58 & 32.54 \\
\hline S. D. & 15.55 & 9.76 & 12.59 & 12.89 \\
\hline
\end{tabular}


was applied to discover if differenoes exlsted between the means for one month intervals. The results of successive t-tests performed and reported in Table VIII revealed no signifleant difference between the rar score means on the group test by age in months over the three month test range of four years-81x months to four jears-e1ght months.

\section{TABLE VII}

DIPFEREMCE BETWEEN MEAHS BY AGE

\section{Age (B1rthdate)}

Decomber - January

December - February

January - Fobruary de

64

62

48 t

.872

.897

.117 p

NS

NS

NS

The alstribution of rav soores by sex are itemized in Table IX. The sample 18 balanced about evenly between boys and 81rls, with the latter acoounting for flfty-three pereent of the cases. A t-test for the difference between means by gex was applied. For 88 degrees of freedom a t-value of 1.988 or 2.633 would be signifloant at the $5 \%$ or $1 \%$ level of alenifloanoe respeotively. The t-value obtalned for the differenee between raw score means $(6.06)$ by sex was 2.306. Th1s differenoe is signiflont at the 58 lerel. 


\section{TABLE IX}

FREQUENCY DISTRIBUTIONS OF RAW SCORES BY SEX

Raw

Soore

$75-79$

$70-74$

$65-69$

$60-64$

$55-59$

$50-54$

$45-49$

$40-44$

$35-39$

$30-34$

$25-29$

$20-24$

15-19

$19-14$

$5-9$

$0-4$

Total

Mean

S.D.
Sex

Male Sex

Total 
TABLE X

DEVIATION INTELLIGBNCE QUOTIENTS

FOR GROUP TEST NOBMATIVE SAMPLE

\begin{tabular}{|c|c|c|c|c|}
\hline $\begin{array}{l}\text { Raw } \\
\text { Soore }\end{array}$ & Boy: & $\begin{array}{l}\text { Total } \\
\text { Sample }\end{array}$ & G1r1s & $\begin{array}{l}\text { Ran } \\
\text { Soone }\end{array}$ \\
\hline $\begin{array}{r}1 \\
2 \\
3 \\
4 \\
5 \\
6 \\
7 \\
8 \\
9 \\
10 \\
11 \\
12 \\
13 \\
14 \\
15 \\
16 \\
17 \\
18 \\
19 \\
20 \\
21 \\
22 \\
23 \\
24 \\
25 \\
26 \\
27 \\
28 \\
29 \\
30 \\
31 \\
32 \\
33 \\
34 \\
35 \\
36 \\
37 \\
38 \\
39 \\
40\end{array}$ & $\begin{array}{c}82 \\
83 \\
84 \\
85 \\
86 \\
87 \\
88 \\
90 \\
91 \\
92 \\
93 \\
94 \\
95 \\
96 \\
97 \\
99 \\
100 \\
101 \\
102 \\
103 \\
104 \\
105 \\
106 \\
108 \\
109 \\
110 \\
111 \\
112 \\
113 \\
114 \\
115 \\
117 \\
118 \\
119 \\
120 \\
121 \\
122 \\
123 \\
124 \\
126\end{array}$ & $\begin{array}{c}78 \\
79 \\
80 \\
81 \\
83 \\
84 \\
85 \\
86 \\
87 \\
88 \\
90 \\
91 \\
92 \\
93 \\
94 \\
95 \\
97 \\
98 \\
99 \\
100 \\
101 \\
102 \\
104 \\
105 \\
106 \\
109 \\
108 \\
109 \\
111 \\
112 \\
113 \\
114 \\
115 \\
116 \\
117 \\
119 \\
120 \\
121 \\
122 \\
123\end{array}$ & $\begin{array}{c}71 \\
72 \\
74 \\
75 \\
76 \\
77 \\
79 \\
80 \\
81 \\
83 \\
84 \\
85 \\
86 \\
88 \\
89 \\
90 \\
91 \\
93 \\
94 \\
95 \\
97 \\
98 \\
99 \\
100 \\
102 \\
103 \\
104 \\
105 \\
107 \\
108 \\
109 \\
111 \\
112 \\
113 \\
114 \\
116 \\
117 \\
118 \\
119 \\
121\end{array}$ & $\begin{array}{l}1 \\
2 \\
3 \\
4 \\
5 \\
6 \\
7 \\
8 \\
9 \\
10 \\
11 \\
12 \\
13 \\
14 \\
15 \\
16 \\
17 \\
18 \\
19 \\
20 \\
21 \\
22 \\
23 \\
24 \\
25 \\
26 \\
27 \\
28 \\
29 \\
30 \\
31 \\
32 \\
33 \\
34 \\
35 \\
36 \\
37 \\
38 \\
39 \\
40\end{array}$ \\
\hline
\end{tabular}


Raw

Soore

41

42

43

44

45

46

$4 ?$

48

49

50

51

52

53

54

55

57

38

59

60

61

62

63

64

65

66

68

69

70

71

72

73
74

75

76

77

78

79

80

81
Total

Boys

127

128

129

130

131

132

133

135

136

137

138

139

140

141

142

144

145

146

147

148

149

150

151

153

154

155

157

158

159

160

162

163

164

165

166

167

168

169

17.

172
Samplo

124

126

127

128

129

130

131

133

134

135

136

137

238

140

141

142

143

144

145

147

148

149

150

151

152

154

155

157

158

159

161

162

163

164

165

166

168

169

170

171

$\begin{array}{ll}\text { Gres } & \text { Raw } \\ \text { Soore }\end{array}$

122

123

124

126

127

128

130

131

132

133

135

136

137

138

140

141

142

144

145

146

247

149

150

151

152

154

155

158

159

160

161

163

164

165

166

168

169

796

172

173
41

42

43

44

45

46

47

48

49

50

51

52

53

54

35

57

58

59

60

61

62

63

64

65

66

68

69

70

71

72

73

74

75

76

77

78

79

80

81 
In Table $\mathrm{X}$ deriation intelligence quotients are reported by sex and total sample for the Group Preschool Soreening rest of Early Entrance to Elndergarten Potentlal1ty, The following

formula ras utillzed to adapt group test raw soores by sex and total samplo into deriation intelligence quotients to approximate the familiar Stanford-Binet IQ distribution:

Deviation $I Q=M+(\sigma)\left[\frac{X_{1}-\bar{X}}{S \cdot D}\right]$

where $M=$ mean of Stanford-Binet IQ's for normatire aamile $\%$ - standard deviation arbitrar $11 \mathrm{y}$ seleoted;

$X_{1}=$ an original raw soore measurement on group test: $\bar{X}$ - mean of normative sample for group test;

SD = tandard deviation of nomative sample for group teat.

In Table XI are found the constants that were plaoed in the foraula except for the varying raw soores to obtain the deviation IQ's by sex and total sanple reported in Table $X$.

\section{TABLE XI}

CONSTANTS UTILIZED IN FOBMULA TO OBTAIN

DEVIATION IQ'S POR NOBMATIVE SAMPLE

\begin{tabular}{lllll}
\hline & M & o & $\overline{\mathbf{X}}$ & S.D. \\
\hline Boys & 112 & 15 & 27.90 & 13.33 \\
G1rls & 113 & 15 & 33.96 & 11.79 \\
Total & 113 & 15 & 31.14 & 12.89 \\
\hline
\end{tabular}




\section{RAPPORT AND MOTIVATION}

The flrst section of Chapter III desoribed the measures taken to establish rapport and maintain the subjeot's motivation. of 94 chlldren, 86 took the group teat on the rlrst attempt to administer 1t to them. Out of the remaining 8 ohildren 4 responded to the second administration. None of the children who init1ally experienoed diffioulty in taking the group soreening test were acoepted for early entranoe on the basis of Individual evaluation follow-ups.

A room monitor was present during the group testing to assist with various administrative detalls, but primarily to make commonts on the behavior of Individual onlidren. Anoedotes were written about 32 of the 90 ohildren in the sample. Only 3 of the 17 ohlidren eventualis acoepted for early entranoe reoelved oomments regarding their group test behavior. As it turned out, one g1rl had poor motor ooordination due to a congenital defect, and medical reports were unfarorable that maturation or treatment would result in striking further development. Therefore, another joar of added growth would probably not have resulted in inproved coordination. The girl was acoepted, sinoe she net the three major oriteria for early entrance contering around superior intelleotual ablilty and, at least, arerage soolal and emotional maturity. One boy exhibited some emotional problems due to disturbed fanlly relationshl ps and rurther Investigation Indicated a 
wait to enter sohool would not $11 \mathrm{kels}$ alleviate the problem. Fam$11 \mathrm{y}$ therapy mas atipulated as a condition for early entranoe in this case. The third onlld's coments referred only to his talking aloud oocasionally wh1le the group test wa in progress.

Uaing test 1tem onlssions as a measure of lack of motivation resulted in the following findings. Of 4,500 possible test responses ( 90 onlidren $X 50$ 1tens on group test) 306 omissions of varlous 1tems were located. Th1s represents seven percent of the total 1 tems or 3.51 tems per group test of 50 1tems. All the ohlidren were given amplo opportunity to respond to all 1 tom sinee eaoh $1_{\text {ton }}$ was tined separately.

\section{SUITABILITY OF TEST ITEMS}

Table XII presents the 1 tem analysis data for the group preschool test by oompering the upper and lower tmenty-seven percent of the sample to obtain the disorinlnative power and difriculty value of eaon Item. Discriminative Indexes were based on values found In the table of Mlanagan oorrelations. 1 Diffloulty Indexes are presented in terms of peroentage of the sample passing an itom. A higher percentage indloates a relatively easior item.

Frequenoy distribution of the 1 tem analysis data appear In Table XIII. Th1 breakdom sumarizes the information for the

IJohn C. Planagan, Meneral Considerations in the Seleotion of Test Items...." J. of Bduoational Parohology. XXX

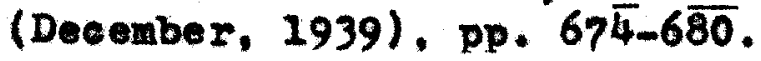


fifty item test. The item disorimination indexes ranged from correlation ooefflolents of 0 to .82 . Porty-seren or 94 percent of the 50 items on the test reoelved a correlation coefriolent of .20 or abore. Porty-three 1 tems have a disoriminating porer of .40 or above. The dirrioulty of the 1 tems ranged from 11 to 90 with a mean peroentage difrioulty of 46.

\section{RABLE XII}

ITEM ANALYSIS DATA FOR GROUP PRESCHOOL SCBEENING TEST

\begin{tabular}{|c|c|c|c|c|c|c|}
\hline $\begin{array}{l}\text { Iten } \\
\text { Number }\end{array}$ & $\frac{\text { Upper }}{\text { Correat }}$ & $\frac{2 \%}{4}$ & $\frac{\text { Lower }}{\text { Correet }}$ & $\frac{6}{9}$ & $\begin{array}{l}\text { Di sorimination } \\
\text { Index (r) }\end{array}$ & $\begin{array}{l}\text { Difrioutty } \\
\text { Index (\$) }\end{array}$ \\
\hline $\begin{array}{l}1 \\
2 \\
3 \\
4 \\
5 \\
6 \\
7 \\
8 \\
9 \\
10 \\
11 \\
12 \\
13 \\
14 \\
15 \\
16 \\
17 \\
18 \\
19 \\
20 \\
21 \\
22 \\
23 \\
24 \\
25 \\
26 \\
27 \\
28 \\
29\end{array}$ & $\begin{array}{r}20 \\
23 \\
24 \\
16 \\
17 \\
21 \\
24 \\
21 \\
19 \\
7 \\
6 \\
24 \\
17 \\
15 \\
22 \\
4 \\
20 \\
22 \\
18 \\
24 \\
13 \\
20 \\
6 \\
14 \\
11 \\
18 \\
5 \\
10 \\
15\end{array}$ & $\begin{array}{r}83 \\
96 \\
100 \\
67 \\
71 \\
88 \\
100 \\
88 \\
79 \\
29 \\
25 \\
100 \\
71 \\
63 \\
92 \\
17 \\
83 \\
92 \\
75 \\
100 \\
58 \\
83 \\
25 \\
58 \\
46 \\
75 \\
21 \\
42 \\
63\end{array}$ & $\begin{array}{r}18 \\
12 \\
15 \\
9 \\
5 \\
7 \\
19 \\
13 \\
13 \\
4 \\
1 \\
15 \\
2 \\
4 \\
6 \\
4 \\
4 \\
4 \\
4 \\
9 \\
8 \\
9 \\
1 \\
3 \\
2 \\
5 \\
2 \\
2 \\
6\end{array}$ & $\begin{array}{r}75 \\
50 \\
63 \\
38 \\
21 \\
29 \\
79 \\
54 \\
54 \\
17 \\
4 \\
63 \\
8 \\
17 \\
25 \\
17 \\
17 \\
17 \\
17 \\
38 \\
33 \\
38 \\
4 \\
13 \\
8 \\
21 \\
8 \\
8 \\
25\end{array}$ & $\begin{array}{l}.14 \\
.64 \\
.69 \\
.28 \\
.51 \\
.59 \\
.62 \\
.41 \\
.28 \\
.16 \\
.42 \\
.69 \\
.65 \\
.47 \\
.72 \\
.07 \\
.65 \\
.75 \\
.57 \\
.79 \\
.25 \\
.48 \\
.42 \\
.50 \\
.45 \\
.54 \\
.21 \\
.43 \\
.41\end{array}$ & $\begin{array}{l}79 \\
73 \\
82 \\
53 \\
46 \\
59 \\
90 \\
71 \\
67 \\
23 \\
15 \\
82 \\
40 \\
40 \\
59 \\
17 \\
50 \\
55 \\
46 \\
69 \\
46 \\
61 \\
15 \\
36 \\
27 \\
48 \\
15 \\
25 \\
40\end{array}$ \\
\hline
\end{tabular}




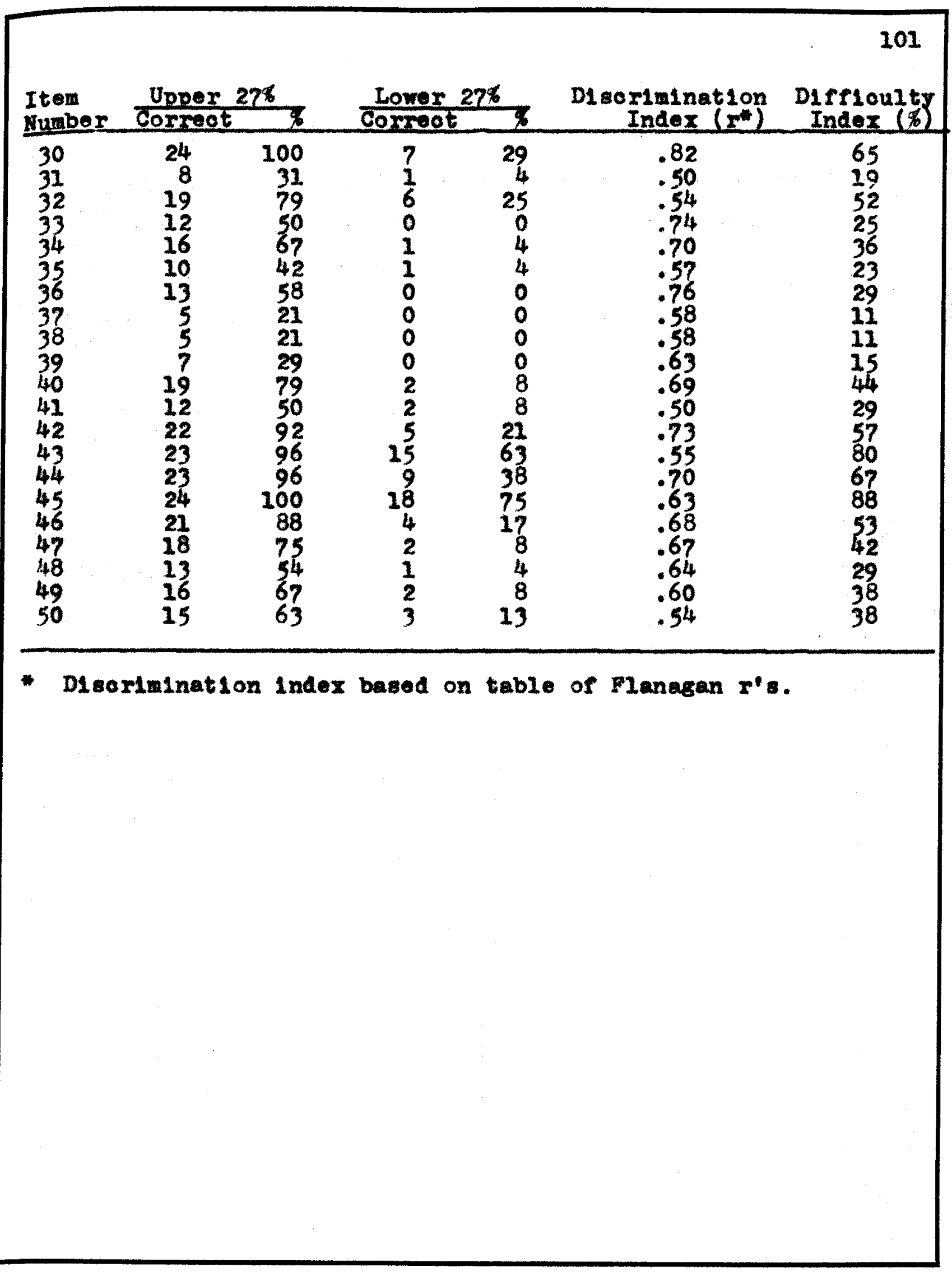


TABLE XIII

PREQUENCY DISTRIBUTIONS OP ITBM ANALYSIS DATA

FOB DISCRTMINATION AND DIFPICULTY INDEXES

Values

Dieorinination $(r)$

Dirrioulty

$.90-.99$

0

1

$.80-.89$

1

4

$.70-.79$

8

3

$.60-.69$

13

5

$.50-.59$

13

8

$.40-.49$

8

9

$.30-.39$

0

4

$.20-.29$

4

8

$.20-.19$

2

8

$.0-.10$

1

0

Total

Kuder-Richardson Forwula 20 was employed to obtaln rellab111ty Indexes for the upper and lower 27 peroent of the samplo. Table XIV reports the results in terms of coefriolents of correlation along with an estimate of the standard errors of measurement. A correlation of .73 and a standard error of measurement of 4.33 was obtalned for the top 27 peroent of the sample. For 
the bottom 27 peroent the data jielded a correlation of .23 with a standard error of measurement of 3.55 .

\section{TABLE XIV}

REIIABILITY ESTIMATES POR UPPER AND LOWER THEHTY-SEVEN PERCENT OF SAMPLE

(Kuder-Riohardson No. 20)

Data

Upper 27 peroent

Lower 27 peroent $\mathbf{r}$

.73

.23
SEm

4.33

3.55
N 24 24

Fire test 1 tens in the group test demonstrate a difrerenoe between the proportions of $\mathrm{glrls}$ and boys responding correotly in the sample. Table XV desoribes these five iteme and Indloates the level of algnifloanoe favoring girls. 
TABLE XV

GROUP TEST ITEMS DEMONSTRATING

A BIAS IN PAVOR OP GIRLS

Item

Number
Desoription of Item
Difference in Response by Sex $(z-800 \times)$
Probab1$116 y$

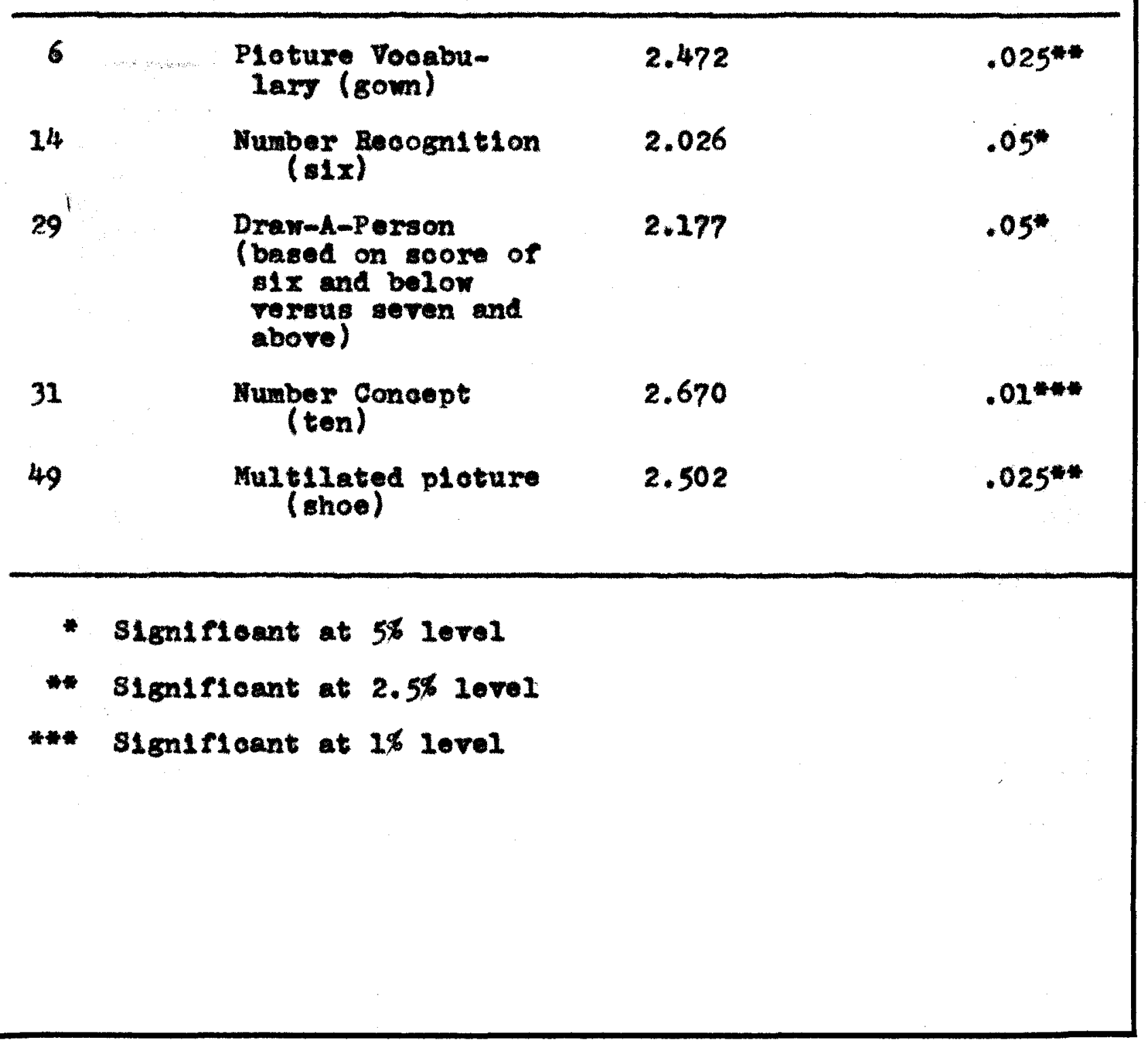




\section{RELIABILITY}

Test-Retest

Two rellability studies involving test-retest with time lapses of four and elent reeks wero oonduoted. Table XVI summar$1 z e s$ the test-retest data on presohoolers ranging in age from four years-rour monthe to four years-nine months whioh yielded correlations of .91 and .87 .

\section{TABLE XVI}

\section{SUMMARY OF STUDIES ON \\ TEST-RETEST REIABILITY}

$\begin{array}{cl}\text { Age } & \text { Time } \\ \text { First resting } & \text { Lapse }\end{array}$

4 ras.; thos: - 8 weeks

4 zra. 6 mos.

4 7ra., 6 mos. - 4 weeks 4 yrs., 8 mos.
Ase

Second Teating

$\mathbf{N}$

The raw soore data on whioh the test-retest rellab111ty studies were based are prosented in Tables XVII and XVIII. 
TABLE XVII

TEST-RETEST RAW DATA FOR POUR WEEK INTERVAL

IN ADMINISTRATION OF GROUP TEST (N = 14)

\begin{tabular}{|c|c|c|c|}
\hline $\begin{array}{l}\text { Test } \\
\text { Number }\end{array}$ & Sex & $\underset{\text { Pesting }}{\text { Testing }}$ & $\begin{array}{l}\text { seoond } \\
\text { resting }\end{array}$ \\
\hline 99 & Q1r1 & 42 & 49 \\
\hline 16 & G1 rI & 40 & 51 \\
\hline 39 & $\operatorname{Gir} 1$ & 37 & 47 \\
\hline 85 & G1r1 & 37 & 35 \\
\hline 105 & GIrI & 35 & 43 \\
\hline 49 & G1r1 & 34 & 26 \\
\hline 33 & G1rI & 27 & 37 \\
\hline 100 & Boy & 23 & 23 \\
\hline 80 & Boy & 20 & 34 \\
\hline 31 & $G 1 \times 1$ & 20 & 22 \\
\hline 14 & $01 \times 1$ & 19 & 27 \\
\hline 64 & G1rl & 18 & 18 \\
\hline 107 & Boy & 15 & 22 \\
\hline 12 & Boy & 8 & 14 \\
\hline Mean & -- & 26.79 & 32.00 \\
\hline S.D. & - & 10.25 & 11.64 \\
\hline
\end{tabular}


TABLE XVIII

TEST-RETEST RAW DATA POR EIGET WEEK INTERVAL

IN ADMINISTRATION OF GROUP TEST $(N=20)$

\begin{tabular}{|c|c|c|c|}
\hline $\begin{array}{l}\text { Test } \\
\text { Number }\end{array}$ & Bex & $\begin{array}{l}\text { Plrst } \\
\text { Testing }\end{array}$ & $\begin{array}{l}\text { Seoond } \\
\text { Testing }\end{array}$ \\
\hline 43 & GIr1 & 56 & 67 \\
\hline 79 & GIr1 & 43 & 49 \\
\hline 8 & a1x1 & 43 & 49 \\
\hline 9 & G1 $\times 1$ & 39 & 46 \\
\hline 35 & Boy & 36 & 45 \\
\hline 1 & Boy & 35 & 42 \\
\hline 3 & Boy & 34 & 37 \\
\hline 7 & Boy & 33 & 57 \\
\hline 47 & Boy & 27 & 31 \\
\hline 101 & B1 1 & 26 & 35 \\
\hline 69 & Boy & 25 & 19 \\
\hline 29 & Eoy & 24 & 28 \\
\hline .45 & G1r1 & 24 & 34 \\
\hline 46 & Boy & 24 & 33 \\
\hline 5 & $01 \times 1$ & 22 & 30 \\
\hline 103 & Boy & 21 & 26 \\
\hline 38 & Boy & 19 & 29 \\
\hline 68 & GIrI & 7 & 17 \\
\hline 90 & Boy & 7 & 25 \\
\hline 28 & Boy & 6 & 10 \\
\hline Mean & - & $27 \cdot 55$ & 35.40 \\
\hline S.D. & - & 12.49 & 13.65 \\
\hline
\end{tabular}


Kuder-Rlohardson Estimates

Reliability of the Presohool Group Soreening Test of Eartr Entrance to Kindercarten Potent1al1ty was est1mated by KuderRichardson formula 20 for the ent1re sample of ninety onildren. A correlation of .88 and a standard error of measurenent of 4.38 was obtained for raw soores.

Hoyt's Analysis of Varlanee

An analjsis of rarlance technlque dereloped by Hoyt was applied to the sample data jlelding a reliablilty of .93 with a standard error of measurement of 3.40 raw sooro polnts. ${ }^{2}$ This use of analyals of varlanoe to estinate rellabllity is oltod as algebraloally equivalent to the Kuder-Riohardson formula 20 although different by formulation.

\section{VALIDITY}

Pace Validity

Pace valldity can be inferred in part from the development and oonstruation of the Group Presohool Soreenlng Test of Earlr Entrance to Xindercarten Potential1ty. A desoription of the test Iteme and their seleotion appeared in Chapter III. The test Itoms may be inspeoted in Appena1x B. The desoription and Inspection of the test 1 tens w1I readily reveal the simllarity of the group

\section{B. J. Winex Statistical Prinoiples in Experimental}

Des18n, Now York: Mocran-HII, I962, p. I24-I32. 
test to other recognized tests of Intelligence since the Items were omplrically derived from suoh sources and then transfomed for group presentation.

Conourrent Val1d1ty

Conourrent valialty ras evaluated by comparing soores on the Group Prosehool Soreening Test of Early Entrance to Kindergarten Potentiality with soores on a reoognized and widely used individual intelisgonoe test. Table VI, referred to previously In this ohapter, reports the relationship between the sroup soreening test and the 1960 Revised Stenford-Binet Intelligenoe Teat, Fom I-M, for a sample of ninety presohool onildron ranging In age frow four jears-81x months to four jears-eight months inelus1re. The Stanford-Binet was seleoted as the prime oriterion sinoe it 18 employed by the majority of sohool distriots in the 11terature who have early sohool admission programs. A correlation ooefrielent of .72 was obtalned in comparing both the rav soores and deviation IQ soores of the group test with StanfordBinet IQ soores in the standardization samplo.

Table XIX braks the data dom in terms of froquency distributions of the group and Individual intelilgenoe test scores. P1gure 1 deplots the date in the form of a soattergram showing the relationship between group test and Individual intelilgenes test soores. Table XX presents the scattergram in tabular forw. Table XXI Is an expeotanoy table that shows the relation between 
the group and Individual intelligenee tests. The goatter alagram In Table XX was converted into an expeotanoy table by expressing each cell frequenoy as a persentage of the corresponding ran total For example, of the 17 subjects tho seoxed between 90 and 99 on the group test, 11 percent ( 2 oages) reoelved individual intelligence test IQ's between 90 and 89,60 pexoent (10 osaes) between 90 and 99,11 peroent ( 2 oases) between 100 and 109, 11 peroent ( 2 cases) between 110 and 119, and 6 peroent ( 1 oase) between 120 and 129 . Given a ohild's sroup test soore, It is posalble by means of an expectanoy table to prediot the chanees of his falling within a oextain intemal on the indiridual teat or critemion ramabio.

The standard error of estimate was osloulated so the test valldity could be rlewed in terms of indiridual prediotion. The error of eatlmate was found to be 11.30 points. This indieates the marcin of emror to be expeted In an Individual's prodicted orfterion soore on the Stanford-Binet as a result of the imperfect falldity of the group test.

\section{EFPICIENCI AND EFFECIVIRSS}

Although 2mdiridual tests were adninlaterod to ouch early entrant candidate along with the group teat for the priary purposes of establiahing norms and conourrent val1dity for the exoup test, th1s data jielded addtional information regarding the effloleney and effeotiveness of the group test as a soreening method for the detection of early entzants to kindergarten. 
TABLE XIX

PREQUENCY DISTRIBUTIONS OF GROUP AND

INDIVIDUAL INTELLIGENCE TEST SCORES

IQ

Intervals
Group Test

Deviation IQ's
Stanford-Binet $I Q \cdot 8$

\begin{tabular}{lcc}
\hline $160-169$ & 0 & 0 \\
$150-159$ & 2 & 1 \\
$140-149$ & 4 & 2 \\
$130-139$ & 6 & 12 \\
$120-129$ & 16 & 12 \\
$110-119$ & 21 & 24 \\
$100-109$ & 20 & 18 \\
$90-99$ & 17 & 17 \\
$80-69$ & 4 & 3 \\
$70-79$ & 0 & 1 \\
$60-69$ & 0 & 0 \\
\hline Total & 90 & 90
\end{tabular}




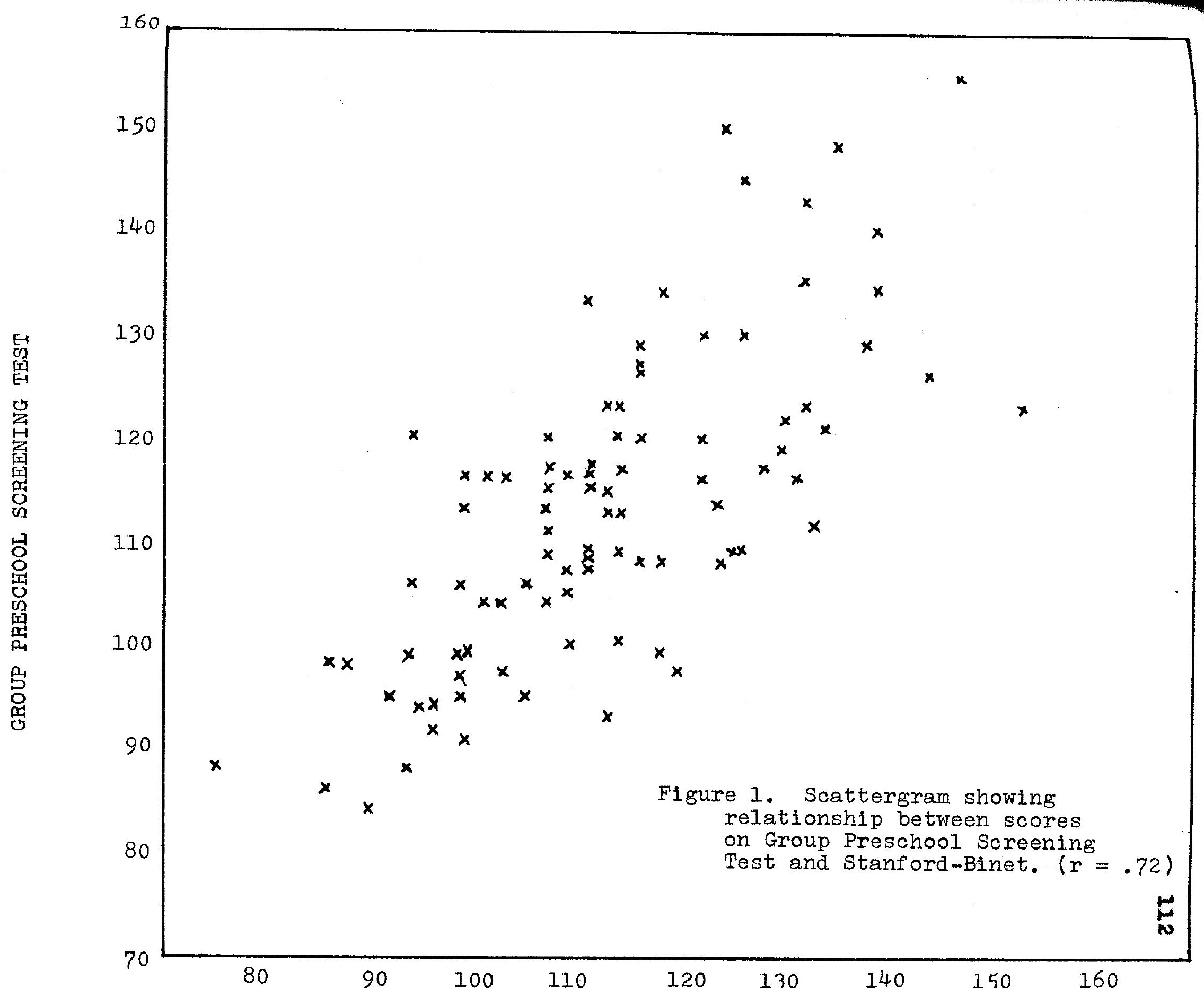


TABLE XX

BIVARIATE DISTRIBUTION SHOWING RBLATIONSHIP BETWEEN TEST SCORES ON GROUP TEST AND INDIVIDUAL TEST

Stanford-B1net Intell1gence Test

\begin{tabular}{|c|c|c|c|c|c|c|c|c|c|c|}
\hline $\begin{array}{l}\text { Group } \\
\text { Test }\end{array}$ & $\begin{array}{l}70- \\
79\end{array}$ & $\begin{array}{l}80- \\
89 \\
\end{array}$ & $\begin{array}{l}90- \\
99\end{array}$ & $\begin{array}{l}100- \\
109\end{array}$ & $\begin{array}{l}110- \\
119 \\
\end{array}$ & $\begin{array}{l}120- \\
129 \\
\end{array}$ & $\begin{array}{l}130- \\
132\end{array}$ & $\begin{array}{l}140- \\
149\end{array}$ & $\begin{array}{l}150- \\
159\end{array}$ & Total \\
\hline $150-159$ & & & & & & 1 & & 1 & & 2 \\
\hline $140-149$ & & & & & & 1 & 3 & & & 4 \\
\hline $130-139$ & & & & & 2 & 2 & 2 & & & 6 \\
\hline $120-129$ & & & 1 & 1 & 7 & 1 & 4 & 1 & 1 & 16 \\
\hline $110-119$ & & & 2 & 7 & 6 & 3 & 3 & & & 21 \\
\hline $100-109$ & & & 2 & 8 & 7 & 3 & & & & 20 \\
\hline $90-99$ & & 2 & 10 & 2 & 2 & 1 & & & & 17 \\
\hline $80-89$ & 1 & 1 & 2 & & & & & & & 4 \\
\hline $70-79$ & & & & & & & & & & 0 \\
\hline
\end{tabular}

TABLE XXI

EXPECTAMCY TABLE SHOUING REIATION BETMEEN GROUP TEST AND STANPORD-BINET

Group Pereentase Beoelving Eaoh Stanford-Binet Seore Interval Test 70- 80- 90- 100- 110- 120- 130- 140- 150-

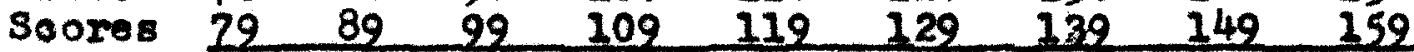
$150-159$ 50 50

140-149

130-139 25 75

120-129

110-119

6

33

33

33

100-109

10

6

44

6

25

6

6

90-99

10

33

29

14

14

80-89

1160

40

35

15

$70-79$

11

11

6

$\begin{array}{lll}25 & 25 \quad 50\end{array}$ 
The effiolency of a screening prooedure may be defined as the ratio between the total number of ohlldren 1 t refers for individual examinations and the number of chlldren actually seleoted as early ontrants among those referred. In other words, the efflolenoy of a test compares the number of ohlldren selected by group soreening with the number of chlidren ldentifled on Individual evaluation in terms of peroent. Thus, if eifty joungsters were referred as possible early entrance candidates on the basis of group testing and twenty-five were accepted in terms of individ ual evaluations, the efflolenoy of the group testing would be 50 percent.

The efrectiveness of the group test refers to the peroentage of early entrants the group sereening procedure locates in the total number of ohlldren tested. If the soreening device located all of the ohlldren eventually accepted for early entranoe 1t would be considered 100 peroent effeot1ve.

Table XXII presents data regarding the erflolenoy and effeot1veness of the Presohool Group Soreening Test of Early Entranoe to K1ndergarten Potent1ality acoording to var1ous cut-off points with five-point intervals. For example, at a out-off score of 50 rav soore polnts on the group soreening test the efflelenoy is 100 percent (group test roferred seven for individual testing and seven were selected for early entranoe) and the effectiveness is 41 peroent (seven early entrants were looated by the sroup test 
out of the seventeen who were eventualiy looated by Individual evaluations). In contrast, out-off score of 30 polnts y1elds an efficlonoy index of 35 peroent (group test referred forty-elent for Individual testing and seventeen were seleoted for early ontrance) and an effeotiveness index of 100 percent (seventeen early sntrants we re located by the group test and seventeen were ldentifled by individual eraluations).

\section{TABLE XXII}

EFPICIENCY AND EPFECTVENESS OF GROUP TRST

BY VARTOUS CUT-OFP SCORES IN SAMPLE

Gut-orf Point

Raw Soore

Deviation IQ

Efriolenoy

Erfectiveness

60

147

100

18

55

141

100

29

50

135

100

41

45

129

71

59

40

123

62

82

35

117

45

88

30

112

35

100

25

106

27

100

20

100

25

100 
PROFESSIONAL PERSONNEL TIME AND EXPENSE

Speolalist's Time

Identifioation and selection or presohoolers for early admission to sohool typloally involves the employment of a psychologist to admister, soore, and interpret individual evaluations for all of the ohlldren. In this study all the presohoolers recelved both group and Individual tests. The group tests were administered to all ninety youngsters and soored within a throe day period. A total of nine rorking days for two psychologists was needed to test the ninety onildren indiridually on a shedule of rive eraluations per day for each psyohologist.

The lowest raw soore on the group test at whioh a child was acoepted for the early entrance to kindergarten program was 30. Using this soore as a out-off soore, forty-eight ohlidren or 53 peroent would have been referred for individual examinations and rorty-two or 47 percent rejested at that point. On a schedule of fire individual eraluations per day, a period of only nine and one-half days would have been neoessary for one psyohologist rather than two psjohologists for nine days as was the case. Soorer Reliability.

To determine if it would be necessary for a psychologist to scare the group test sinoe an element of subjectivity is 
involved in some of the test items, scorer rellability was checked Scorer reliablitty was ascertained by randomly selecting thirtyeight test protoools from the total sample of ninety. Onif thirtyelght of the teats were used to check scorer rellabll1ty because 1t wes deemed convenient and practical to $11 \mathrm{mlt}$ the number of tests to be scored. These records were then distributed to three separate individuals without identifying date to bo soored independently by a housewife (B-Mrs. A. Edward Ahr), sohool alerk (C-M1ss Diana Krauss), and kindergarten teaoher (D-Mrs. Rochelle Palman). As a gulde, the scorers were given a oopy of the direotions for scoring but no further assistance was offered.

\section{TABLE XXIII}

SCORER RELIABILITY INTERCORBELATIONS

Soorers

Psychologlst
(A) Payohologist
(B) Housent fe
(c) Clerk
(D) Teaoher

.993

.994

.993

.993

.988

.993

Table XXIII presents the soorer rellablilty rindings. The reliabilities of the three soorers with the sooring by the payohof logist (A) were: B, .993; C,.994; and D, .993. The correlatlons between non-speciallsts were: $B+C, .993 ; B+D, .988 ;$ and $C+D, .993$ 
Spec1al1st's Expense

As stated previously, ninety chlldren evaluated individually by two psyohologists on a basis of rive per day amounts to nine working days for two psyoholog1sts. Relmburgement was at a rate of $\$ 50.00$ per day resulting in an expenditure of $\$ 900.00$ for both psychologlats for a nine day period.

\section{TABLE XXIV}

PERSOMNEL EXPEMDITURES FOR EARLY ADMISSION PROGRAM

Personnel

Duty

Rate

Expenditure

One Psyohologist

Individual eraluations

$\$ 50 . /$ day

$\$ 475.00$

Two Teachers

Group teating

$\$ 18 . / \mathrm{day}$

72.00

One olerk

Group test sooring

$\$ 12 . /$ day

12.00

Total

$\$ 559.00$

Table XXIV aumearizes the oost for personnel to oonduct the progrem based on using a out-off score of 30 on the group test The psyohologist's feo for servioes rendered is epproximately out in half. Total expense 18 out by more than a thind in terms of personnel costs. Secretarlal services, frollities, and olassroon costs for those children aocepted were not considered because thes would remain relatively stable whether or not group test was used as a soreening procedure. 


\section{CONSIDERATION OF QUESTIONS}

Question (1). Can rapport be established and malntalned in a group setting at the preschool level and sultable test items be devised and administered?

Decision. Yes. Ninety of 94 presohool onllaren were able to separate from their parents, enter the testing room and respond to the group test st1mul1. Item analys1s data in Table XII and XIII Indicates the test iterg are highly disoriminating, yet maintain average diffloulty.

Question (2). Does the group screenlng test have sufficlent ro$11 \mathrm{ab} 111 \mathrm{tg} ?$

Dec1sion. Yes. Rellabllity of the group test oaloulated in three distinot manners and presented in Tables XVI and XIX indicates a band of correlations between .87 and .93 whioh is well within an acceptable range.

Question (3). Does the group soreening test have sufflolent ralldity?

Deolston, Yes. Por the purpose for which the group test was deviged - as a soreening instrument - the oonourrent ralldity demonstrated with the major oriterion, Stanford-Binet, Form L-M, 18 quite satisfaotory. 
Question (4). Is the group test an efficlent soreening instrument Deolsion. Yes. Depending on the unlque characteristios of a sohool and community, a cut-off seore oan be seleoted to fit specirio needs. As compared with the method typically ut1lized to refer chlidren for individual evaluation, parental request, the soreening test demonstrates considerable superiority.

Question (5). Is the group test an erfective soreening instrument Decision. Yes. The peroentage of chlldren located by the group test that are aotually acoepted for early entrance on the basis of Individual examinations oan be adjusted according to the type of sohool and community to the level of effect 1.veness nost desirable in a situation.

Queation (6). Does the use of the group soreening test result in sevings in terms of proressional pergonnel time and the outlay of funds in an early admission program.

Deolsion. Yes. Timesarings and fewer expenses are attributable to the group soreening test, sinoe considerably less ohilaren are referred for timeoonsuming, expensive indivia ual eraluations. 
CHAPTER VI

DISCUSSTON, CONCLUSTONS AND BECOMMENDATrONS

GROUP TEST NORMATIVE DATA

Any norm is restrioted to the partloular nornative population frow whioh it was emplrioalls derived. The present norms for the Group Pronehool Sereenlng Bet of Earlx Entranoe to Eindergarten Potentiallty represent the test performance of ninety. white, upper-middie-olass, suburben ohildren between the ages of four years-81x months and four years-elght months who constituted the standardization sample. Admittediy, the present semple is not a representative oross section of the population for which the group test oould be ut111zed. Laok of finanolal backing as woll as a host of additional problems did not permit a broader study In terms of a one-man Investigation team. Nerertheloss, a samplo was chosen wich corresponded wth several suburban oomunities in the United states where early admission programs are annually conduoted.

Having noted the 1 inltations of the present sample regardIng its size and representation, it should be recognized that it may ultimately be more practloable and effective procedure to atandardize a teat on a narrovly defined or local population 1nit1ally. Should the test prove its worth in aotual praotice, 
as seems to be the oase with the group soreening test, additional samples could be employed to expand the boundarles of the normative population. Adaltional evidence of this type would allow the deseription of the present noms to be generalized acoordingly.

The norms presented in this investigation for the group test should teohnloally be thought of as $100 a l$ norms which are applicable only to communities sinllar to the sample desoribed. Since speolflo norms permit more acourate prediction of an individual's perfoxmanoe than general norms, the present norms appear defonsible as well as desirable.

Orlginal raw soores on the group test were first transformed into standard soores. Suoh a linear transformation allow the relative magnitude of differences between the standard soores and raw scores to remain the same and permits evaluation of an Individual's perromence in referenoe to other persons. A furthe I1near adaptation was perrormed to provide a direot comparison of an Individual's performance on different tests. A standard deviation of 15 was ohosen for the group test so the resulting deviation IQ's could be interpreted in the same way as StanfordBinet IQ's even though the same methods wore not employed to obtain the "IQ*.

Table VIII on page 93 revealed no $81 \mathrm{sn} 1$ ficant differences between the raw seore means on the sroup test by age in months over the three wonth range of the group test. Consequentiy, it 
It seemed unneoessary to develop subgroup norms on the basls of age in terms of one month intervals.

A differenoe between the means by sex was found to be slgnifleant at the $5 \%$ level of simiflcance. Accordingly, separate deriation IQ's were reported on page 95 in Table $X$ for boys, glrls, and total sample to allow greater coeuraoy in interpreting an Individual's score. Inspection of the group test norws by sex reveals a 10 polnt Ie alfferenoe at the botton of the scale with no observable differenoe at the top. At an IQ score of 120 on the combined distmitution for both sexes, the margin of difference between sexes is 5 points; IQ 130, 4 points; IQ 140, 3 polnts; and IQ 150,1 point. The greatest difforenoes in terms of sex appear within the average and below average range. sinee the test was specifically designed to have a high oelling and discrininate at the upper levels of ablitty. the alferences at the lower levels by sex are of $11 t$ tie consequence in terms of the primary purpose for which the group test was devised. Thus, separate norns for sex were presented nainly in the interest of prosenting highly speotflo norras.

That aubgroup nozns do roveal anrked disorepancles in wany teats has been repeatedly denonstrated. To olroumvent this happening, test construstors chose test items to minimize certain group differenoes whioh are consldered irrelerant to the purposes of the test. A case in point is the stanford-Binet in whioh an 
attempt was made to eliminate the ffeots of an itom whioh favored elther sex by exclusion of belanolng of sex differentiating items.

No special effort was formulated elther to minimize or maximize sox difrerentiation on the group test. Five test items on the fifty ltem group teat demonstrated aignificant aifferenoes at the $5 \%, 2.5 \%$, and $1 \%$ levels of signiflcanoe favioring g1rls. These items account for a possible 20 points out of a possible 81 points.

A plaugible explanation for the sex differences on the test, other than asguming that the 1 tems refleot irrelevant difrerenoes in the experienoes of the two sexes, may be to attxibute the differences to the manner in mion tentative group test 1tems were initially centred. In generel, more 61 rls than boys correctIy responded to subtest itema on the individual tests whioh were eventually transformed for presentation on the group test.

\section{RAPPORT AND MOTIVATION}

In the revien of the I1terature the pitfalls involved in the development of a preschool group test were discussed. The faot that no group test at the presohool level had been previousiy publlshed supported the lack of feasibility in suoh an undertaking

sighty-81x of ninety four ohildren or 91 peroent of the preschoolers took the group test on the flrst administration. The youngsters who did not take the test were unable to be 
separated from thelr parents. All elghty-six ohlidren, and later four others, who actually entered the testing room responded to the test. In order for the preschoolers to take the test they had to sit quietly, 11sten, think, follow disoctions, and respond in presoribed manner. To accomplish this task it would appear reasonable to Infer that a certain degree of rapport, Interest, or motivation had to be present to allow the subjeots to perform the funotions demanded by euch an endearor.

An examiner and monltor were present at each administration of the sroup test. Both kept a 108 of coments regarding any unusual bohavior noted. Two-th1rds of the roungsters did not show any outward slgns of distress, nor make any observable indication that could be interpreted in a negative sense. These data sugseat that the majerity of the preschool subjects in the sample were sufflolently motivated and relaxed enough to not only endure but w111ingly partiolpate in a meaningful, struotured setting.

Further evidence of meaningful oooperation was offered in terms of the total possible reaponses and actual number of items not marked in the standardization sample. Ninoty-three poroant of all the test items were marked by the ninety children. Ihis Indicates a sustained effort on the part of the subjeots whioh would be unllkely if they lacked rapport or interest in the test. 


\section{SUITABILITY OF TEST ITEMS}

The characteristios of the items whloh compose a test directly affect the rollablilty and valldity of the tegt. Through 1tem analysis the test oan be refined and improved by selection; subst1tution, or revision of 1 tems.

In referense to the group soreening test it should be noted that different samples of subjeots were used for item seleotion purposes and for standardization of the test. This satisfied the demand for eross-valldation whi oh has reoelred inoreasing attention over the years in test construetion. Techniques involvod during the prelininary 1tom seleotion phase were roported in Chapter III.

The Item analysis of the group test in the standardization sample was conoemed prinarily with two characterlstics of the test 1tems, namely, diffloulty ralue and diserininating power. Table XII and XIII on pages 100 and 102 presented date regarding these 1tom oharaoterist108 for the fifty 1tem group test.

The group test was designed to oover a wide range or difrloulty but to differentiate mainly at the upper lerel of the range. Basy items were inserted at the beginning and intermittent If throughout the test to arouse confidence and maintain the motivation of the subjeots. Inspection of the 1 tem analysis data reveals that the diffloulty of the group test 1 tems was laded 
wdely distmbuted and thereby met the standard imposed by the invest1gator.

The measurement of 1 tem diffloulty provides an index of the order of Aiffloulty of the items and 18 generally utilized to rearrange the 1 tems cooording to diffloulty level in a porer test. Th1s was not done in the group test because the investigator pelt that altemeting sequenoes of easy and hard iteras for motivational purposes was more important at the presohool level.

Item discrimlnating power was estimated in the form of oorrelation coefficlents reed directly from tables prepared by Flanagan. Th1s method ma used to reduce the amount of computatlonal labor required. Th1s method appeared justifled on the bas1s that rariation in 1 tom ralidity data from sample to sample 18 generally greater then that among the different methods avallable to oompute 1 ten disorininative value.

The upper 27 pereent and lower 27 peroent of the standard1zation sample was compared to permit a olear-out ovaluation of 1tem-criterion relationshlps. Considerable intemal consistenoy was found in the correlations with total scores on the test. The fact that rorty-three of the fifty items have a disorininating power of .40 or above indicates that the test itens have oonsiderably more diseriminating power than ant1elpated on the basls of the prior data obtalned on the prelininary item seleotion ample. 
Item 16 on the presohool group test whioh 1s 111ustrated In Appendix B recelved a correlation coefficient value of zero. This item was the only one which did not yleld a positive disoriminating index.

A prelininary attempt to rovise 1 tem 16 was tested with a sample of fourteen presohoolers whioh were representative of the ent1re atandardization sample. P1gure 2 deplets the auggested revised replecement for 1ten 16. Diriding the sample at the median, a correlation coefrielent of .70 was obtained. The difficulty index was 57 pereent. The epeolflo adninistration direotions to the ohlidren are: "Mark the ralndrop that 1 a abore the oloud."

\section{BRLIABILITI}

The rellability of a test refers to the consistenoy of sodres obtained by the same individuals on different ocoasions or with ifferent sets of equiralent items. There are many techniques avallable for measuring test rellabllity. The nost obvious method for flinding the rellablilty of tegt is by means of repet1tion of the ldentioal test on a second oocasion. The rellability coefficient is simply the correlation of the soores by the same subjeots on the two administrations of the test and prorides a measure of temporal stabl11ty. This type of measure indloates the degree to whioh sooxes on a given test are affected by randow da11y Iuotuations in the condition of the subjeot or of the 


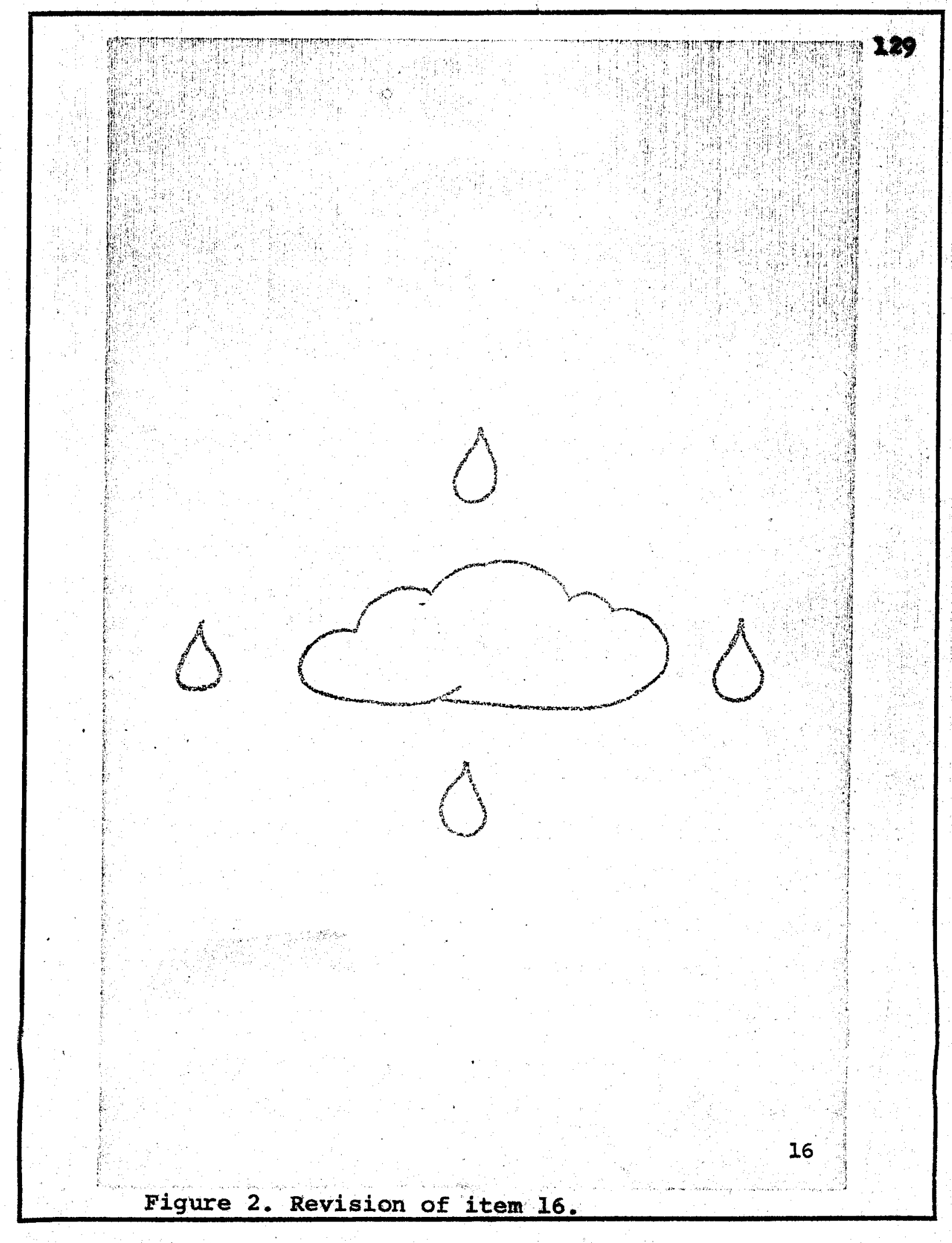


testing enviroment.

Tables XVI, XVII, and XVIII on pages 105,106 and 107 reported raw score data and rellabllitles for short-range intervals of time on two separate test-retest administrations of the group test. Considering the small s1ze of the samples ( $N=20$ and $N=14)$ and the presohool age letel, the resulting rellabllity ooefflclents of .91 orer an aght-week t1me lapse and .87 for a fourweek Interval may be interpreted as indieating a rery high positire oonsiatenoy and stab111ty rating for the group test.

The time intervals between tests was kept short for two major reasons. First, the 1rvest1gation was oonoerned with stably. 1ty of performance within a restricted three-month age range as opposed to constaney of perromance over a wide age-time range. seoond, the interval of time between separate adinistrations of the group teat had to be kept as short as feaslble due to the presohool age level for whioh the test was designed. At suoh early ages progressive developmental ohanges are notioable over a perlod of a fer months or less.

The test-retest teohnique does present sone problems in sruluating a psyohologloal test. Praotioe effeot oould have produced a degree of improtement in retest soores of different individuals. Memory or reoall due to the short interval between teats way have produced the same patterm of Mght and wrong responses. If the effects of practice and memory oause the soores 
on the two test aduinistrations not to bo independently obtained, the resulting correlation between then would be spurlously high. Th1 s 18 one reason why other teohniques for establiahling the relle b111ty of the group test were employed.

The group test employed an individual test itou time ilmit long onough to permit ouoh subjoot to attoapt oach Iten. In this sense the group test $1 \mathrm{~s}$ moro $11 \mathrm{ke}$ a power test than a spesd test and permlte the application of a single-trial method of oheoring rellablitty. The Kuder-fiohardson Formula 20 measures test reliablilty by exaplaing the conslsteney of the subjeots' responses to all 1tems on given test. Thus, based on alngle adninistration of the sroup test, a measure of 1 te inter-1ter consisteney mas determined and offers evidence of the degree of homogenelty of the test 1tens.

The Kuder-Richardson Formula 20 rielded a rellablitty coerriolent of .88 Indloating very high degree of inter-1tew consistenoy or homogenelty. This finding is similar to the two previousiy reported rellablilty coerfiolents and suggests that the test-retest rellablilties were not fpuriously high as suspected on the basis of contanination due to practice effect or memory.

A second method for establishing the rellability of the group test on the total standardization sample was emplored in the form of an analysis of vartance teohnique developed by Hoyt. 
Although olted in the 11terature as algebraloaliy equivalent to the Kuder-Rlchardson formula, it differs in formulation. The Hoyt mothod of analysis jielded a rellability ooefflolent of .93 whioh again indicates very high degree of positive consistenoy In the group preschool soreaning test.

An 1mportant factor influenolng the slze of any reliabliity ooefriofont is the nature of the group on whioh reliabli1ty wes measured. Not only does the rellablilty coefflolent rary with the extent of Individual differenoes, but it may vary between groups differing in ablitty level, sex, and age, as well as other factors. Thus, the standardization sample wa fractionated into more homogeneous abgroups to be more applleable to apeolflo group.

Table XIY on page 103, repoxted a muoh higher rellabll1ty for the upper 27 peroent of the standardization group (r=.73) then for the lower 27 pereent $(x=.23)$. Bren though the group test as a whole enjoys a high rellability rating, the subgroup ability level data indleates that scores in the upper thind of the test are considerably more dependable than in the botton third. In explanation of this faot, It should be noted that the soores of subjects in the lower third were reatrioted in range to about one-half of that found in the upper third of the standardization sample. Hore important, the teat spec1f108.11y constmoted to have a high oelilng for purposes of finer discrimination at the upper lerels to soreen mentally ablo ohlldren for early 
entranoe to kindergarten. Consequently, this result is not surprising in vien of the purpose for which the group test was designed.

Subgroup data in terms of sex, ylelded a rel1ab111ty coefflolent of .96 for boys and .88 for girls. These findings indicate a high degree of consistenoy and dependability in relation to soores obtalned, regardiess of sex.

In terms of subgroups by age, rellablitty coefficients of $.92, .81$, and .89 were obtained for the subjects in the sample who would become fire in December, January, and February, respectively. Again, it is readily apparent that the group test enjoyed a high degree of reliablilty when the standardization sample was fragmented into one month chronologloal age intervals.

The standard error of measurement provides another method of expressing the rellablitty of a test and 18 more userul in terms of interpreting the soore of a given individual. The error of measurement indioates the ruotuation to be expected in a test score due to ohance factors. As deteralned on the basis of two separate rellabllity measures $(r=.93)$ and $r=.88$ ) the error of measurement for the presohool group test ranges between 3 and 4 raw soore points or 4 and 5 deviation IQ points. This means that two-thirds of a group taking the presohool group test w111 obtain soores whioh would not differ from their true (unimown) soores by more than the value of the standard exror of measurement.

Sinoe 
the error of measurement tends to remain uniform in groups approxlmating the same abli1ty level, it oan be applied to new groups which may differ considerably in varlabllity from the group on which the stat1st1c was orlginally determined.

The standard error of measurement for the extremes of the standardization sample was found to be 4 rar score points in both the upper and lower 27 percent groups. In terms of subgrouping by sex, the standard error of measurement was 3 rav soore points for boys and 4 points for $81 \mathrm{xls}$. The error of measurement by age subgroups was 4 ray soore polnts for eaoh of the one month intervals.

\section{VALIDITY}

Test validity, in general, refors to how well a test measures what 1 purports to measure. Before disoussing objective measures of the group test ralidity, let us consider its faoe ralldity. This is a subjeotive indication of what the group test appears to measure. Inspection of the group test 1 tems in Appendix B 111 readily reveal the similamty of the 1 tems to 1tems faund on rarious indiridual intelligenoe tests at a preschool level or group achievement or intelligence test at the primary sohool level. The plotorial, non-verbal nature of the Items holds appeal and interest for the joung onild. Considering the emplyioal basis on whioh initial try-out 1tews for the group test were obtained from various individual tests and then 
tronsfored for srous presentation in pletorial mannex, it is ersily understandable why the group tost could be oonsidered as demonstrating a rather high degree of faoe validity. Certalniy the face ralidity of the group test does not attest to, nor replaoe the need for object17e vallalty. It can, however, be regarded as an Indication of what the group test wight be neasuring and suggest that it 18 relerant for the purpose for whioh 1 was designed. Namely. the group test was intended for use with presohool ohlldren as a screening instrument to deteruine whether rurther Individual evaluation woldd be advisable for possible selootion in the early entrance program.

Conourrent val1dity mas measured by obtalning a correlatlon between the presohool group test and the highly rated Stenford-Binet indiridual intelilgenoe test. This latter test can properly be regarded as the primary ortterion moseure for sereral reasons. The Stantond-Btnet is utillzed as the main individual Intelligenoe test in earlj adrision to school prograns in the Onited states. The group test $1 \mathrm{~s}$ belng validated against a more elaborite and time-consuning indiridual test wose vallalty has previously been eateblished. At best the group test should be regarded as a orude approxination of the individual test. Horerex. the use of the indifidual test as a oriterion ia quite defensible sinoe the group test represents a simpler, shorter verston for group sereenting purposes. Furthermore, since there was previoustr no group test araliable the preschool level, the group test 
represents a new horizon in test development and oonstruotion and 1118 a rold heretorore present for educators at the initial and cruolal phase of formal education.

Table VI on pages 89,90 and 91 , reported the relationship between the preschool group soreening test and the stenford-Binet, Ferty-y, for the standardization sample of ninety presohool chlldren between the ages of four years-81x months and four yearse1ght months. A correlation between the two tests of .72 was oomputed. Since the sample was restricted to white, upper-middle olass, suburban presohoolers of mich a high pereentage were Jewlsh, the effect of such preseleotion may have tended to lower the validity ooeffiolent. Conversely, it should be noted that for Individual or group tests on the market have ralldity coeffiolents abore .70. Plotorlal and tabular data shoring the relationship between soores on the group and individual test were presented In Figure 1 on page 112 and Tables XIX, XX, and XXI on pages 111 and 113. Predletions of scores in the expectaney table on the oriterion. Stenford-Binet, on the basis of the group test are subjeot to considerable aampling error, espeolalis in view of the saall number of cases. Indiridual peroentages rere based on relativels fow persons falling within a single oell. For this reason ohanoe fluotuations in the pereentages from sample to samplo would quite $11 \mathrm{kely}$ be large. Converselj, presentation of validity data 7 expeotanoy tables $1 \mathrm{~s}$ rivid and olear, permitting examination of the prediotive value of the test reganding the 
oriterion in different parts of the range.

The question of how high a valldity coefflelent should be can not be answered in a general way. An interpretation of this nature depends heavily upon how the test soores w1ll be used.

For Individual prediction, test ralldity can be interpretad through the standard error of estimate, which is analogous to the error of measurement disoussed in the proceding section on rellablilty. In this oase the error of estlmate demonstrates the margin of error expected in the Individual's predioted oriterion soore on the stanford-Binet, as a result of the imperfeat raildity of the group test. The term $\sqrt{1-x^{2} x y}$ in the formula for the -rror of estinate is oalled the coerflolent of allenation and indloates the slze of the error in relation to the exror which woun result from a chance guess. The coofflolent of allenation corresponding to the group test val1dity ooerflolent of .72 was .69, mioh Indloates the error 1869 peroent as large as it would be by ohance. Sinoe the rallaity of existing published tests rarely exoeeds .60 or .70, one may conolude that the prediotion of any one subject's oriterlon soore is aooompanled by a wide marsin of orror. Th1s is 11kewse readily apparent in the standard error of estimate for the group test which was oaloulated to be 11.30 IQ polnts.

The primary funotion of the Presohoel Group Soreening Test of Early Entrence to Xindergarten Potentielity is not topro- 
alot each individual' exaot position in the oriterion. The group test was dealgned to determine whioh Individual would exoeed a oertain minlmum etandard of porformanoe in the oriterion. The group test oan efreotively be employed as a coroening instranent to prediot that a given person has a good ohanoe or pasalng the early ontranoe seleotion program of wion the stanford-Binet is a najor part, even if the group test is unable to estinate with oertalnty whether the Individual w1I cohlere a soore of IQ 130 or 140. When used for soxwening purposes, a teat may appreolably 1eprore predietive efflolener if it bhows any gignifleant oorrelation wth the orterion, howevor 10w. Bren teste wth validitie as low as .20 or . 30 have been Inoluded in some seleetion program. Further alsouseton of this tople w12 be found in the following seotion portalning to the offeotivenose and effiolonoy of the prosohool group teet.

The tine 1inlte imposed upon this etudy by the inverticator ald not permit prodiotive vallisty in teme of correlations between the group teat soores and future acadonio sohierenent of testees to be obtalned and xpported. Suoh dats of a Ionsltudinal nature is recognized and ralued and wil oventually be seoured, but was not wthin tha noope of the prosont investigation.

\section{EPICTENCY AD EPRGTIVIESS}

Table XXII on pege 115 oumarized the erfloteney and offectiveness of the group test at rantous out-oft levela. sineo 
early entrance programs in general have no ver1fled mothod avallable to them as soreening procedure, onlldren referred for indiridual evaluations are obtained through parental request. In terms of effloleney of a soreening procedure (the rat1o between the total number of ohildron referred for individual evaluation and the number of ohildron actually selected in percent), parental request referred 90 chlldren of whioh 17 were eventually selected for early admision, ylelding an efflolenoy sating of 19 percent. Ualng a cut-off score on the group test of 30 rav score points it would yteld 48 referrals for individual testing of which 17 were aooepted resulting in an efflolency rating of 35 percent. The differonoe between these efficienoy indexes represents the net erficienoy of the group test emplojine the speoifled cut-off point. It indioates the contribution wich the sroup test makes In the seleotion or Individuals who will meet the minimum standards in the oriterion performanoe. In the oase olted the group test almost doubled the efflolenoy rating of soreening based on parent request. By raising the raw score cut-off point on the group test, efflolency oan be adjusted to any lovel desired. For 1nstance, the group test out-off score of 40 would yield 62 percent efflolenos, tripling the parental request efficienoj index of 19, wh11e a cut-off score of 50 would gain 100 percent eff1olenoy for the group test, thus quadrupling the parental request efflolenos rating.

Another way to demonstrate the efficiency of the group 
test, as a soreening devioe, is to consider the number of false positives inoluded in the soreening procedure. A false positive refers to an Individual which the tost exroneously selects as a possible early entrant who should be individually evaluated. The same data that was used in calculating efflolency ratings is used but is not converted into peroentages. The use of perental request as a sorening device resulted in 73 false positives (90-17) On the group test a out-off raw score of 30 ylelds 31 false positives $(48-17) ; 40$ y1e1ds $8(21-13)$; and a score of 50 ylelds no false positives $(7-7)$.

The above data demonstrate the userulness of the proschool group test as an effiolent soreening device and its superiority over mere parental request which is typloally used in early admission programs as the sole inltial soreening teohnique prior to individual testing. In addition, it highlights the plexibility of the out-ofs points. Cut-off points can be adfusted to the unique characterist10s of differing schools and communities to meet Individual local sohool needs.

The offectiveness of a soreening device refors to the peroentage of eariy entrants looated in the total number of ohildren. At a raw score out-orf point of 30 on the group test all 17 chlldren eventually acoepted for early entranoe were located, indicatIng 100 percent effeotiveness. Likewise, all 17 preschoolers erentually acoepted for early admission were located on the basis of parental request. However, in order for the parental request 
teohnlque to jleld 100 peroent effectiveness 90 ohlldren hed to be individually evaluated thereas the grouo screening test accomplished the same degree of effectiveness with onl 48 indiridual evaluations.

\section{PROFEBSIONAL PERSOMNEL TIME AMD EXPENSE}

The results elearly demonstrate that the use of the group tegt as a screening device is more economical in terms of both the outlay of funds for psychologloal services as well as tiresaving for professional personnel. At a raw soore out-off of 30 points on the group test, all early entrants eventually soleoted were included in the reoommendation for individuel testing. Individual evaluations of 48 rather than 90 on the basis of parent referral represents a savings in time of elght and one half days for one psyohologist (18-9 $1 / 2)$ and a savings in expense of $\$ 425.00$ (\$900-\$475). In those cases where a school alstriot eaploys 1 ts own psychologist for a twelve month period and a psyohologist therefore would not be contracted specifically for the early admission program evaluation, the savings in time for suoh a school staff nerber oould be devoted to an array of other professtonal tagks.

Examlner rellabllity was assumed to be surflolently high for practioal purposes due to the $h i g h l y$ standardized procedures provided for administration of the group test. As long as the presoribed procedures are followed carefully resulting in an 
emplrically set of controlled oonditions, there is no need for measuring this type of rellabl11ty.

Scorer rellablilty for the group test could have been assumed for the same reason. Howerer, five of the 1 tems on the group test involved varying degrees of subjeotivity in terms of scoring and acoount for a possible 24 polnts on the 81 raw score point.test. In addition, to demonstrate that it was not necessary for a p8ychologist to soore the group test, soorer rellability was aseertalned and reported in Table XXIII on page 117. The re11ability ooerflolents reported in terms of correlations between the four scorers leave no doubt as to the equivalence of the four scorers in view of the near perfect correlations obtained. Thus, further sarings of a speolalist's time and sohool expense can be achleved through the presohool group test adminlatration by teachers and sooring by clerks.

\section{CONCLUSIONS}

This investigation by itself does not provide sufficient evidenoe to adrocate the unrestrioted use of the preschool group test in varying sohools and communities. First, the laok of a large and representative sample precludes a broad generalization regarding the rindings but permits generalizations to settings which are similar in nature to the sample ut1lized in the present study. Seoond, the results of a single investigation with a group test at the presohool level mich heretofore had not been 
studied, 1s obviously far from onclusive. A final evaluation of the attributes of the sroup instrument and technique within the presohool level at this stage would be highly imprudent. Third, sinoe the investigation was conduoted in but one school district, regardless of the preolsion and acouracy as well as the statist1cally satisfying results, the possiblilty of preselection effects and of uncontrolled variables operating to affeot the data may have been present. Fourth, the rindings of the study should in no way be mlsconstrued to suggest that the group test could be substituted for an indiridual evaluation for diagnostio purposes or used to make orttical doolsions of oonsiderable importance whloh domand supporting data from a varlety of tests or teohniques

With the above Ilmitations in mind, the outatanding facts whioh seem to be disolosed by the findings of thls investigation have been 11sted:

1. Presohool onlldren between the ages of four years $-81 x$ months and rour years-1ght months in a wite, uppermidale olass suburban school system were able to respond to a test designed for group administration and presentation. This would seen to strongly indicate that it 18 possible to test presohool ohlldren of th1s baokground in a sroup setting.

2. The orerall results of the investigation seriously question previous 11 terature whioh indicated the laok of 
feasiblilty of group testing at the presohool level.

3. Groups of presohool onlldren larger than fifteen in number were adminlstered the group preschool screening tes with the assistance of additional personnel. This would seem to challenge common practlce and statenents in the 11terature which indicate no more than 10 to 15 ohildren at the kindergarten level should be tested in a group setting at one time. Perhaps, mass testing oan be accomplished in school at early age levels in large groups or T12 olosed olroult television without seorifloing any testing principles. Such a teohnlque may even mean sup- Hor emplrioal control of the testing oonditions sinoe all students at speo1f10 level would have the sane examiner and test setting.

4. The results of the investigation are reatrioted in terms of the generalizations that can be offered. Speclally, the results of the study may only be generallzed to school systems and oommunities whioh are similar In make-up to the present standardization semple.

5. The majority of the preschoolers were able to separate from their parents, onter a strange physical and soolal environment, sit quietig, 11sten, think, follow dirotions and respond in a prosoribed matter to the group test stimul1. To acoomplish this task it would seem plausible 
to Infer that a certain amount of rapport, 1nterest, or motivation was established or present to all the presohoolers to perform the runctions demanded by suoh an ondearor.

6. The group preschool screening test was able to discriminate well between the upper and lower levels of ab111ty. Mis would appear to suggeat that the 1tems seleoted for the group test were sultable for the use for whioh they were intended, namely, to soreen out those youngsters who were $11 \mathrm{kely}$ oandldates for early admission for the purpose of adminlstering indiridual exeminations for final Identification.

7. The consistency of the results in terms of re11ab11Ity coefflolents suggests that it is possible to obtain dependable group test results at the preschool level.

8. Subgroup norms are not only desirable, but mandatory, for proper interpretation of test results when the test construction does not involve procedures to elininate or balance the effects of certaln faotors, 11 ke sex.

9. The size of the oorrelation between the group test and the highly rated individual intelligenoe test suggests that it 18 possible to obtain suffiolently high validity for the practioal use of a sroup sereening test at the presohool 1erel. 
10. The group test demonstrated its efficlency and offeotiveness as a soreening procedure for a speciflo set of oriteria in a particular setting. Th1s suggests that It is posalble to develop an efficient and erfeotive group sereening lnstrument at the preschool level but each varyIng tjpe of sohool or community would have to devise its own out-off points in regard to the nature of the local progran to be meaningrul.

11. The use of the presohool test as a soreening instrument ouggests that cons1derable school expense and speolalist's time can be saved by reduoing the number of individual evaluations needed in an early adnission program.

\section{RECOMHENDATIONS}

In view of the findings of the investigation, the followIng reoommendations have been suggested:

1. That a larger and wore representative sample be emploged to derelop general normative data and subgroup norns to allow the use of the group test in differing schools and commities.

2. That the results of the present study be published and wiely disseminated to educators and psyohologists since it not only represents a teohnique for soreening 
at the preschool level but an extension of group testing to a level heretofore uninvestigated.

3. That elementary administrators, through consultants or staff personnel, make avallable to kindergarten and clessmom teachers 1 is. In-service education programs the researoh 11 terature ooncerning early entrance to kindergarten programs.

4. That the teohniques for selection as well as the early entranoe program 1 tself be viewed as but a part of a total sifted program within any sohool distriot.

5. That workshops and conferences di rected at sohool administrators be organized to investigate the merits of early entrance progrems and 1 ts relationship with currioulum modifications.

6. That elementary prinolpals and teachors, especially kindergarten teachers, examine, study, and aoquaint themselves with the extensive f1eld of 11teraturo on early entrance prograns.

7. That elementary prinolpals and teachers be given an opportunity to $\nabla 1$ is school systems employing an early entrance program and disouss, as woll as observe, the results. 
8. That the need for continued and thorough research and Investigation of the potentialities of preschool group soreenling instruments and early entrance programs be fully reallzed and onoouraged by adminlstrators and sohool psyohologists who here great responsibility for making Innovations arailable to sohools for prectloal use.

9. That the preschool group screening test be extended downward to the below normal abillty lerels to obtain more reliable results at this level of performance.

10. That the presohool group soreening test nomative deta be extended upward ohronologloally to determine if the group test has merit in offering kindergarten teachers a means of grouplng regular kindergarten ohildren early in the school year for the purpose of more indirldualized Instruction as we11 as identify the extremes for further Individual evaluation.

11. That differences in iten diffloulties as woll as in orer-all soores be Investigated in relation to soclocoonomle status, oultural background, and methods of presenting the 1tems.

12. That longltudinal studies be initiated to obtain data regariling prediction of elementary aoademic achievement from early chlldhood soores on the group preschool soreening tegt. 
13. That factor analysis at varlous age levels be applied to determine what the group preschool soreening test appears to be measuring at different ohronologloal agea.

14. That prodiction of reading and other learning problems in the early grades on the basis of group preschool screning test soores be thoroughly investigated.

15. That carly adralsaion soreening programs not only be used to help in the seleotion of bright ohildren who appear ready to begin school eariler, but afford a sohool distriet the opportunits to ut1lize preventive approach by ldentifying ohlidren with problems and seeking means of Initial remediation of treatment at the sarliest and most oruclal phase of formal eduoation. 


\section{CBAPTER VII}

\section{SUMRARY}

This atudy Involved the development of the Group Presohool Soreening Test of Barly Entrance to Kindergarten Potentiality and was designed to obtain necessary standardization statistics and teohn10al data.

The subjects included ninety-preachool onlidren between the ages of four years-six months and four years-elght months who would $\mathrm{mls}$ the migld chronologloal date set by the state for automat10 admission to kindergarten by from one to ninety deys. The sample vas derlved from a suburban school distriot looated in a white, upper-middle class oomunity in which a slgnifloant proportion of the familles were Jewlsh.

The 1tems on the preschocs. sroun test were emplrioally derived by comparing the results of ohildren acoepted and rejected In an early sohool admission progrem on the basis of seroral individual tests. The Individual test items which demonstrated the highest disorimlnating power were transformed for group presentation and inoluded in the initial try-out form of the presohool group teat.

The initial group test composed of 691 tems was then administered to a different group of preschoolers to determine 
which of the adapted test 1 tems malntalned their discriminative power. Fifty items were retalned in the group test for the present study.

Several breaks with traditional test development appeared necessary in the formulation of the flrst group test at the preschool level. Brief activity perlods were provided prior to and in the middle of the group test to establish and maintain rapport, reduce fatigue and restiessness in a structured setting, and sat18 fy the need for motor aotirity. The group test alternates the sequenoe of easy and diffloult items to permit the subjeots to maintain motivation throughout the testing period. Ta stimulate and foous attention, only one test item was presented per page and each page was a different oolor to fac111tate administration. Provision for adequate spacing or cardboard dividers between ohlldren was necessary because inltative beharlor 18 typlcal at the presohool level.

The group test 18 divided into two booklets of twentyf1ve 1tems each plus denonstration 1tems. FIre 1tems involve oopying, drawing or printing. The remaining items are of the multiple oholoe variety in whloh the subjeot marks his oholoe of one of the outilne drawings with penoll.

The group test, the 1960 Revised Stenford-Binet, Hide Range Achlerement Test, and Drav-A-Man Test were administered to the standardization sample within a two woek period. Identifica- 
tion of early entrants was made exolusively on the basis of the Individual evaluations.

The results suggest that it 1 s feasible to employ a group test as a screenine derio at the presohool level. Independent measures of rellabllity for the total sample ranged between .88 and 93. In terms of the standard error of measurement, two thiteds of a group taking the presohool group test would obtain soores whioh would not be expeoted to differ from thelr true soores by more than 4 raw soore points. Concurrent validity measured by comparing soores on the group test with the Stanford-Binet, Form I-M, ylelded a correlation coefficient of .72 , Indicating ample validity for group soreening test. Discriminative power of the items ranged between .00 and $.82 \mathrm{wth}$ a mean correlation of .54 ; 1tem diffloulty ranged between 11 and 90 with mean diffioulty peroentage of 46 . The superiority of the group soreening test over the typical method of referral for individual evaluations in early admission programs (parent request) in terms of effloienoy and effeotiveness was demonstrated by varlous suggested out-off points on the group test scores. Sarings of school expense and special1st's time was demonstrated through the use of the group soreening instrument as opposed to wholesale individual oraluat1ons of all candidates for carly entrance to lindergarten.

The lack of a large and representative sample preoludes any broad generalizations regarding the findings but permits generalizations to settings whioh are simliar in nature to the standardization sample. The data does offer strong evidenoe to 
challenge certain popular bellefs, suoh as, the Infeasibility of group tests at the presohool level, the prevalling fear of testing more than fifteen subjeots in a group of oven kindergarten age and that suffiolent rapport and sultable itens cannot be establish ed or selected at the presohool level.

Reoommendations for rurther researoh we nighlighted by the following suggestions: (1) Upward ohronologloal extension of the group test range to Investigate Its use as a means of grouping at the beginning of kindergarten to allow for more individualized instruotion; (2) Investigation of differences in 1tem diffloulties and total soores on the group test in relation to soc10-00onom10 status and oultural baokswound; (3) Invest1gation of prediction of reading and other leaming problens in early grades on the basis of the group presohool soreening test; and (4) Use of early admission soreening prograns not only to select bright ohlidren who seen ready for kindergarten, but as a broad prevent1ve approach in Ident1fying presohool ohlldren with problems and seeking means of Inltial remediation or treatient prior to the ohild's entry into the oruclal and beginning phase of formal eduoation. 


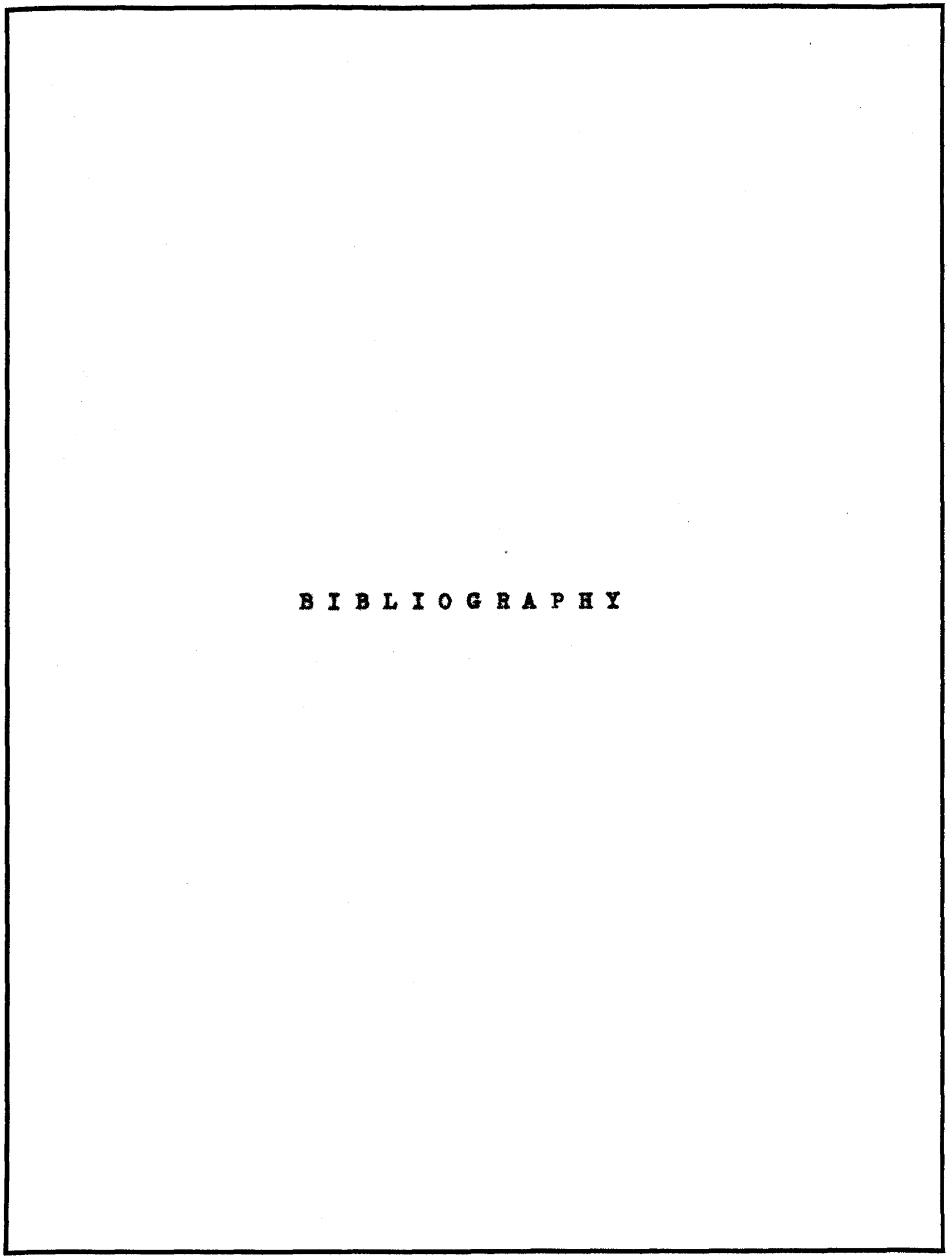


BIBLIOGRAPEY

A. BOOKS

Anastasi, Anne. Porehologteal Testing, Hew York: Macmillan Co., 1954.

Anderson, R. E. (Bd.) Heseareh on the Acaderleally Felented Student. Washington, D.C.: Wational Bducation Assn., 1961.

Anderson, J. B. "The Nature of Abilltles". In E. P. Torrance, (Ed.), Telent and Education. MInneapolis: UnLver. of Mmn. Press, 1960.

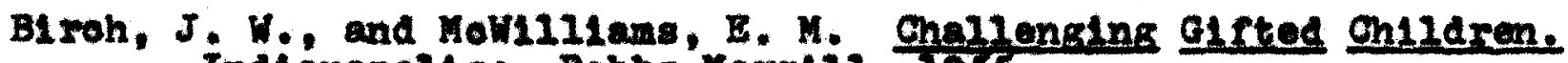
IndLanapol1s: Bobbs-Merm11, 1955.

Buros, 0,K. (Ed.) The Plth Mental Measurements Yearbook. Highiand Park, T.J.8 Gryphon Press, 1965.

Burks, Barbara S., Jenson, Dortha, and Terman, I. M. Genetio Studies of cenlus. Vol. 3. The Promise of Youth. Palo Ato. Califomiat stantord UnITer. Prose, 1930.

Cox, Cathorine, ot ax. Genetye Studies of Genlus. Vol. 2. The Barly Mentel raits of Three Iundred Genluses. Palo Alto, calltornial stantord Unitr. Tress, 1925.

Cronbach, L. J. Esgent1ale of Psrohologioal Testing. New York: Harper, 1949.

Crow, L. D. and Orow, Al100. Educating the Aoademioally Able. Hew York: David Mokay Co., 1963.

Cutts, H. S., and Mosoley, M. Teaching the Breght and Gleted. Nor York: Prentloe-Lali, 1957.

Gallagher, J. J. Teachleg the Glfted Ghild. Bostons Allyn and Beoon, 2964.

Hollingworth, Lota S. Gifted Ghildren: Thelr Hature and Hurture. New Iork: Macinitian, 1926 .

I18. Franoss L, and Ames, Loulse B. Sohool Readiness. New Yorks Harper and Bow, 1965. 
Jenkins, Gladys G., Shaoter, Helen, and Bauer, W. These are Your Chl1dren. (Expanded a.) Ch1eago: Soott Foresman and Con 1953.

Keys, N. The Underage Student in High Sohool and Collese. Bexkeley: Univer. of Callfomla Pres: 1938.

Lehman, H. C. Age and Aenlerenent. Prinoeton, M.J.: Frinoeton Univer, Press, 1953.

M11es, Gatherine C. "Glfted Children". In L. Carmiohuel (Ed.), Yanual of Chlld Peroholos,. New York: John W1Ier and Sons, 1955, 886-953.

Norrys, Dorothy, t. al. Prograns in the Elementary Sohoole. Iearbook Nat. Soo, stud. Eduo. 1958, 57, Part II. Chlongot Univer. of Chleago Press, 1958, 222-262.

01son, W. C., and Aughes, B. O. Growth Patterne of Exoeptional Children. Yearbook Hat. Soo, Stud. Edve.. 1950.49, Part II, ChIoego: Univer. of Chlongo Press, 1950.

Reynolds, H. C. "Acoeleration". In E. P. Tormenee (Bd.), Talent and Eduoetion. Himneapolis: Univer. of Minnesota PFes, 1960, 106-125.

Terman, L.K., ot al. Genet 10 Studieg of Genlus, Vol 1. The

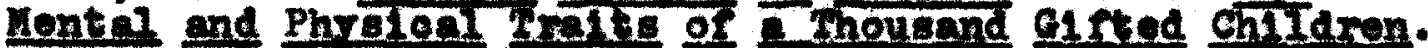
Palo Alto, Calltormias stantord intrer. Pross, 1926.

Terman, L.M., and Herr111, Kaude A. Stenford-Alnet Intellikenoe

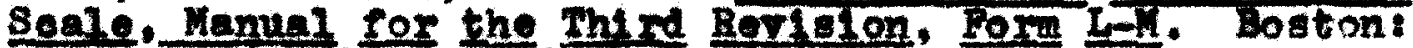
Houghton $1 \mathrm{Ir} 1 \mathrm{In}, 1960$.

Torman, L. M., and Oden, Mellta H. Genetlo Studies of Genius. Vo1. 4. The G1fted Ch11d Growe Up. Palo Alto, Callfornia Stanford Untver. Proes, Igh7.

Teman, I. M., and Oden, Molite H. Genetlo Studies of Genius Vo1. 5. The Gifted Group at TId-Lire. PaIo Mito. Califormiat stanford Univer. Press, 1959.

Winor, B. J. Statiatloal Prinolples In Experinemtal Desism. New Yoxkt Mocrav-BII, 1962.

Worvester. D. A. The Edueation of On11dren of Abore-Arerage

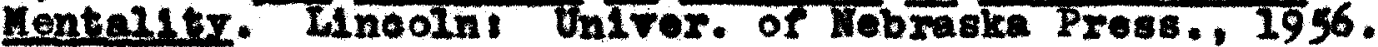


B. PUBLICATIONS OP THE GOVERMENT, LEAEMED SOCIETIES, AND OTHER ORGANIZATIONS

Baer, C. "A Comparison of the Sohool Progress and Soolel Adjustment of Underase and ororese Pup11 of comparable Intelligence dü Ing Eleven Learg ln School." Kansas CIty. 10.1 Kansas CIty Publio shoole.

College Edueation Bureau of Sohool Servise. "Hor O1d Should a Plrst Greder Be?" Lexington: Univer. of Kentuoky, 1958.

Dav18, F. B., Lesser, G.S., Prench, E. G., et al. Identlfleation and Glessroom Beherilor of Gleted Elementary sahool

ChI1dren. In The GIfted Student, 0:-35016, Cooperat1re heseareh Monographs Mo. 2, J. S. Departinent of Heal th, Education and Welfare, V. 3. Orfloe of Edncation). Washingtion, D.C.: U, $S$. Govermment Printing offloe, 1960.

Devault, H. V., E1118, B. C., Vodloke, E, H., and Otto, H. J. Underase F1 rat Grade Enrollees: The1r Aohlerement and Personal and soaral Adrigtient." Austint Univer. of Texa.s, 1957 .

Edueational Polleles Comisston. Education of the Glrted. Washington, D.C.1 Nat L onal bdroation ABsm. 1950.

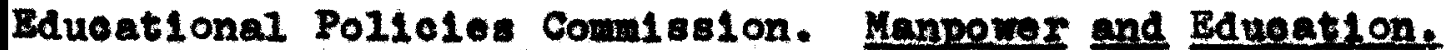
Washington, D.C.: National Eduoation ABgn. 1956.

Gallagher, J. J. The Glfted Chlid in the Elementar sohool. Amerioan Eduoabiona Bescaroh Asen. Bulletin Ko. 17 Hashingtion, D.C.: National Education Assn., 1959.

Gallsgher. J. J. Analrats of Begearoh on the gduoation of Gifted chl1dren. Springitold, III.: of fice of the superintendert of PubIIo Instruetion, 1960.

Goodenough, Florence I., Haurer, Eatherine M., and Van Wagenen, M. J. Mirnesotie Presohool Beales: Revieed Manual. Minneapolis: Eduoational Test Bureau, 1940.

National Eduoation Assoolation. carten and Plrst Grede. Washington, $\frac{\text { D.C.: }}{\text { iuthor } 1958 .}$

Admisaton Polloles for KinderCI toular No. 3, 1958 (Aprit). 
158

Pressey, S. I. Acoeleration: Basio Prinolples and Reoent Research. Proceedings: 1954 Invitational Conferenoe on Testing Problems. Prinoeton, N.J.8 Educational Testing Servioe,

Pressey. S. L. "Eduoational Aoceleration: Appralsals and Bas10 Problems," Bureau of Educational Mongr., Columbus, Oh1o: oh1o State Un1rer., 1949, No. 31.

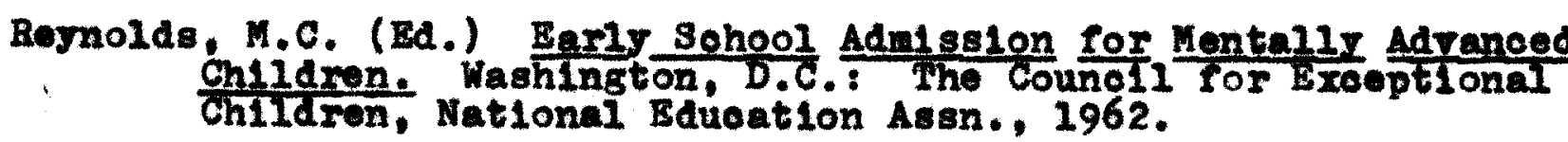




\section{PERIODICALS}

Abrahan, W. "Who's to Blame for Plrat Grade Fallures" Todar's Health, XXXVIII $(1960), 34-35$.

Albera, Toseo B. "Readiness for Kindergarten", Eduoation, IXXXIII (1962), 165-168.

Ammons, Margaret P, and Goodlad, J. I, "When to BegIn", Chlldhood Edueation. XXXII $(1955), 21-26$.

Barbe, H. B. "Career Aohl erement of G1fted students". Ramannal Gutdanoe Joumal, XXXIV (1956), 356-359.

Barlow, R. J. G. "Progreas and the Gifted", Grade Teacher, IXXV $(1958), 18$.

Bayley, Naney. "Consistenoy and Varlablilty in the Growth of Inteli1genoe from BI rth to Elghteen Years". I. Genet10 Peroholost, IXXV (1949), 165-169.

Bayley, Naney. "On the Grouth of Intel11gence", American Peroholostat, X (1955), 805-818.

Baylej, Naney. "Educational Measurements", Rerter of Edueation Besearroh, XXVI (1956), 268-291.

B1gelow, Ellzabeth. "Sohool Progress of Under-Age Children", Elenentarx Sohool Journal, XXXV (1934), 186-192.

B1roh, J. W. "Early Sohool Admissions for Mentally Adranced Children", Exoeptionel Ch11dren, XXI (1954), 84-87.

B1roh, J. W., T1sdall, W. J., and Barney, W. D. "Early Adaission of Able Cnildren to school", Sohool Life, XIVI (1964), 7-8

Brunner, Catherine, "Projeot Helps Progran for Early Admission". Eduestion Digest, XXIX (1964), 22-25.

Carroll, H. A. "Intelleotually Gifted Ch1Idren, The1r Charaoter$18 t 168$ and Problems". Teeoher Collere Reoond, XIII (1940), 212-227.

Carter, I. B. "Erfeot of Early Sohool Entranoe on the Soholastio Achlevement of Blementary Sohool Children in the Austin Pubilo Schools". Joumal of Eduestional Besearoh, L (1956) 91-103. 
Chauncey, H. "Hov Tests Help Us Ident1fy the Aoadealoally Talonted" National Edueation Assoolation Journal. XLVII (1958): $230-231$.

Clark, W. W. Boys and G1rls! Are There Slenlfloant Abllity and Aonievement DLfrerences?" Phl Delte Eappan, XII (1959), 73-76.

Conlskey, Kathleen, H. "Aooent on Youth". Hetlonel Blonentay Prinolpel, XXXVI $(1957), 24-25$.

Cone, H. R. "Brookline Adnits Them Early", Nation'B Sohools, IV $(1955), 46-47$.

Corl1ss, W. 3. "Early Sohool Entry for the G1fted", Minnesota Journal of Bdueation, XIII (1962), 12-13.

Dev18, H. H. "Don't Pueh Your Sohool Hoginnors", Parent's Megazing XXVII (1952), 140241.

DeHaen, R. F. "Ident1 fring G1fted Chlldren", Sohool Rerlew. Ir (1957), 41-48.

Dennis, W. "The Ago Deorement in Outstanding Solont1r10 Contributions: Paot or Artifaot?". Angrloan Parcholos1st, XIII (1958). 457-460.

Edalston, A. W., and Bollahan, C. E. Measures Prediot1re of F1rst Grade Aónlevement", Sohool and Socletr, IXII (1946). 268-269.

Engle, J. L. A study of the Erfoots of Sohool Aoceleration Upon the Perwonality and Sohool Adjustment of H1gh Sohool and University studenta". Joumel of Edueat lonal Perohology. XXIX (1938), 523-539:

Palmield, R, P. "Defeots of A00oleration", Sohool and Sooletr. Iratis $(2953), 292-294$.

Flanagen, J. C. "General Conslderations in the Selection of Test Items...". Joumal of Edueation Peroholosy, XXX (1939). $674-680$.

Fleaher, Harle A., and Pressey, S. L. WVar-t1me Aocelerates Ten Iears After". Joumal of Educatlonal Perchologr, XIVI $(1955), 228-238$.

Porester, J. J. "At What Age Should a Ch1ld start Sohooli", Sohool Erequt1re, LXXIV (1955), 80-81. 
Fliegler, L. A., and Blsh, C. F. "The Glfted and Talented in the Eduoation of Exceptional Children". Rerler of Educational Besearreh, XXIV (1959), 5.

Gates, A., and Bond, 6. L. Meading Readiness: A Study of Faotors Determining Sucoess and Fellure in Beginning Reading". Teachers Collese Beoond, XXXVII (1935), 679-685.

Goldbers, H. I. "Regeargh on the Talented", Pesohere College Hecora, IX (1958), 150-153.

Goodenough, Florence L. "The Bnotional Beharior of Young Children Durlng Hental Teats". Joumal of Jurenlle Besearoh, XIII $(1929), 204-219$.

Green, D. R. and Stmons, S. V. "Chronologloal Age and Sohool Bntrano", Elementer School Joumal, IXII (1962), 41-47.

Hall, R. V. "Does Entzanoe Age Afreot Aohlevenonti", Elementary Sohool Journal, IXIII (1963), 391-396.

Hanalaenin, A. E. "KIndergarten-Primaxy Entrance Age In Belation to Later Sohool Ad justment". Elementarr Sohool Joumal, III (1952), 406-411.

Hampleman, R. S. "Study of the Comparative Reading Aohlerements of Eaxly and Late School Starters". Elementam Engl1sh. XXXVI $(1959), 331-334$.

Hausman, F. J. "Ready for Plrst Grade?", Sohool Ereoutere, XLIX $(1940), 25-26$.

Heinz, H. W. "Whon to sohool"", Chllahood Eaveation, XXVIII (1952) $318-321$.

H11dreth, G. H. "Age Standards for F1ret Grade Entranoe", Ch11dhood Edueation, XXIII (1946), 22-27.

Hobson. J. R. "Mental Age as A Workable Criterion for Sohool Adisission". Eleventerr Sohool Jouma1, XIVIII (1948). $312-231$.

Hobson, J. R. "HLgh Sohool Perfomanoe of Underage Puplis InItialn Aduitted to Kindergarten on the Basis of Physical and Psychologloal Tests". Eduoatlonal Psroholostoel Measurment. XXIII $(1962)$, $159-170$.

Honz1k, M. P., Maoparlane, Jean, and MIIen, L. "The Stab111ty of Hental Test Performance between Two and B1ghteen Iearg". Joumal of Experimental Education, XVII (1948), 309-324. 
"Hopplng Like a Bunny - Kindergarten Admission Pol10y", Time, IXVI (1955), 45.

House, R. W. "Primary Criterie for Adjusting the Currioulum to the ChIld", Bohool and sooletr, LXXI (1950), 9-11.

"How 01d Should a P1 rst Grader Be?", Catholle Education Berlex, LVI (1958), 415-416.

Justman, J. "Personal and Soolal Adjustment of Intelleotually Gifted Acoelerants and Non-20oelerants In Junlor High Sohool", Sohool Bev1ex, LXI (1953), 468-478.

Justman, J. "Aoademic Aoht orement of IntellectuallJ Gifted Accelerants and Non-accelerants in Junlor High Sohool", Sohool Bevlex, LXII (1954), 142-150.

Justman, J. "Aoadem10 Aohlerement of Intellootually Gifted Acoel- rants and Non-aooelerants in Senlor HIgh Sohool". School Rov1ex, LXII (1954), 469-473.

Kazlenko, L. W. "Beglinner Grade Influenoe on Sohool Progress", Eduentional Adnindstration and Supervialon, XI (1954), 219-228.

KIng, I. B. "Bffect of Age of Entrance Into Grade 1 Upon Aohlevement In Elementary Sohool", Elementerr Sohool Journal, IN $(1955), 331-336$.

Larson, A. "Barly Admission Bxperiment of the Fund for the Adrancement of Education", Education Forim, XXIII (1958), 101-108.

Lehman, H. C. "Men's Creative Produotion Rate t Different Ages and in Different Countries", selentifio Honthly. LXXVIII (1954). 321-326.

MawhInney, P. E. "We Gare Up on Early Entrance", Mych1san Edueation Journal, XII (2964), 25 .

Maxwe11, J. "What to do about the Boys?", National Education Assoolation Joumal, XIIX (1960) 26 .

MoCandiess, B. B. "Should Batght Chlla Start Sohool Before He's F1reP", Bdueation, LXXVII (1955), 310-375.

Millex, Vere V. "Aoedemlo Achlerement and Social Adjustment of Chlldren Young for their Grade Placement", Elementerr Sohool Joumal, LXII (1957), 257-263. 
M1ller, Vera V. "Education of the Gifted", Amertoen Sohool Board Joumal, (1959), 23-27.

Monderer, J. H. "An Braluation of the Nebraska Progran of Ear1J Entrance to Elementary Sohool", Dlssertation Abstracts, XIV (1954), 14.

Mueller, K. "Srooess of Elementary Students Admitted to Publio Schools under the Requil rementa of the Nebraska Program of Barly Entranoe", D1saertation Abstraats, XV (1955), 2103.

Nimioht, G., Sparks, J., and Mortensen, A. "Is there a Right Adrissi on Age?", Oterflex, IV (1963), $41-43$.

Oak-Bruce, Lura. "What do we Know-for Sure?", Chllahood Edueation XXIV (1948), 312-316.

Pauly, F. B. "Sox Difforences and Legal Sohool Entzence Age", Joumal of Eduoatlonal Beseareh, XIV (1951), 1-9.

Pauly, F. R. "Should Boys Enter Sohool Later than G1 rls?" National Eduoation Assoalation Journal, XI.I (1952), 29-31.

Pauly, F, R. "Lot's Gire Boys a Broak", Ph1 Delta Kappan, XC (1959), 4.

Pressey, S. L. "That Most Misunderatood Concept-Aooeleration", Sahool and Soolety. LXXIX (1954), 59-60.

Pressey, S. L. "Educational Aoseleration: Oosestonal Prosedure or Major Issus?", Personnel and Guldance Joumel, XLI (1962), 12-17.

"Primary Bntrance Test", The TImes Edugational Supplenent 2347, Now York Times, (

Bowland, T. D., and Nolson, C. C. "Off to Sohool at what Age?", Elementary sohool Joumal, LX (1959), 18-23.

Sohtndlor, A. H. "Beadiness for Learning", Onlldhood Eduoation, XX́r $(1948), 301-304$.

Sohindler, A. H. "School Admisaton and Promotion", Mational Eduogtion Agsoolation Besearoh Bulletin, XxxvII (1959), 13-15.

Shannon, D. C. "What Researoh says about Accelerat 1on", Phi Delte Kappan, XXXIX (1957), 70-72. 
"Should Beginning Puplls be Admitted on Mental Age? - an Oplnion Poll", Nation's Sohools, LVI (1955). 6.

Smith, B. M. "Conference on Non-1ntelleot1ve Determinants of Aohlevement" Soolal Solenoe Besearoh Counoll Iteng, VII (1953). 13-18.

Stake, R, E, "Predioting Suooess of the Barly Starter", Oremier, $v(1960), 32-34$.

Stom, 6. E. "Age Reduoed for mtering Grade 1-A", Elementers Sohool Joumal, XEVII (1946), 7 .

Striokland, futh G, and PILohta, Phyl11s. "Age of Entrance into First Grade". Indlana Unlverst tr Sohool Eduoation Bulletin $X X V(1949), 7-12$.

Terman, I. M. and Oden, Mel1ta H. Major Issues in the Eduoation of G1fted Ch11dren". Joumal of Teagher Eduontion. V $(1954), 230-232$.

Thoupson, J, and Heyer, L, H. "that Researoh sajs About Acoeleration". Seconda Eduoat10n, XXXVI (1961), 301-305.

Thomd1ke, R. I. Problems in Identifieation, Desertption and Derelopment of the Gifted". Tesohers Collere Beoond. XLII $(1941), 402-406$.

We1ss, Bosalee G. The Valldity of Barly Bntranoe into Kindergarten". Jeumal of Eduational Rasearoh, IVI (1962),53-5t.

H1son, F. T. "Survey of Bdueational Provistons for Young Gifted Children in the United States and of Studies and Problens Belated Thereto", Pedasosy Seminar, LXXV (1949), 3-19.

M1Ison, F. T. "Bvidenoe about Acoeleration of Glfted Youth", Sohoel and Sooletr, IXXIII (1951), 409-410.

W11son, F. T. "Bducators" Opinions about Aoeeleration of Oifted Student s", Sohool and Soclety, IXXX (1954), 120-122.

Witty, P. "Hor to Identify the Gifted", Gh11dhood Edueation, XXIX $(1953), 312-316$.

Woroester, D. A. "Methods of Acoeleration", Anerlean Sohool Boend Joumal ext (1960), 11-13.

Wright, G. S. "Permiasive Sehool Entrance Ages in Looal Sohool systems", Sohool Hife, XXVIII $(1946), 20-25$. 


\section{UNPUBLISHED MATERIALS}

Bedolan, V. H. "Soclometrlc Status and Mental Health of Overage and Underage Pup1is in the S1xth Grade." Unpublished dootoral dissertation, University of Southern California, 1950.

B1roh, J. W. The Brfectiveness and Feasibility of Barly Admission to School for Mentally Adranoed Children." Peper dellvered at Conferenes of the Amerioan Eduontional

Besearoh Asan., Pobruary 20, 1962. (Mineo.)

B1rch, J.W. "What Does 'Sohool Readiness" Mean?" Paper dellverod at Annual Convention of Amerioan Psyohological

Assoolation, September 3, 1965. (M1me0.)

Broullette, Jeanne S., and Miller, Vera V. "Adulasion Practice in Publ10 schools." Evaneton. Ill.: Comunity Consolidated Sohools, D1st riet 65, January, 1950. (Unpubil shed.)

Godrrey, Susan E., ot al. "Sehool Bntrance Age In Relation to Prowotion and Ion-pronotion." Toledo, Ohio: Board of Bduoation, Maroh 29, 1954. (Mimoo.)

Hobson. J. R. "Practieal Criteria for Sohool Readiness." Paper dellvered at Annual Conrention of American Psychological Assoolation, September 3, 1965. (M1meo.)

M1ller, Vera $\nabla$. "A Stuay or Soolal Adjustment, Pereonality Chercoteristios and Aoademie Achlerement of Underage Junlor H1gh Sohool Pup11s." 1960. (Unpubl 1shed.)

M11ler, Vera V. "Ch1ldren Young for the1r Grade." Evanston, I11.: Research Department, Community Consolldated Sohools, Januaxy, 1949. (unpubis shed.)

MInneapol1s Publ10 Schools, (Dept. of Adn. Res.) "Kindergarten Adulssion Age." Mínneapolis: Author, 1957. (M1meo.)

Sm1th, J. "The Sucoess of Some Young Chlidren In the LIncoln, Hebraske Publio Sohools." Unpublished master's thesis, Univer. of Kob. 1951.

Thompson, G. R. "Barly Adm1s81 on to Kindergarten." Paper submitted to skok10 D18triot 68 Board of Edueation, May 26, 1964. (M1 meo.) 
Werner, Eway Soolal Competence of Kindergarten and Fifth Grade Children as Bvaluated by the Vineland Social Maturity Soale." Unpublished dootoral dissextation, University of Nobraska, 1955.

w11son, "Soreening Inst ruments and Ago Requirements for Kindergarten." Bakersfleld, Callfornia: Kerm County Pub110 Sohools, May 5, 1961. (M1meo.) 
A PENDICES 


\section{APPENDIX A}

\section{GROUP PRESCHOOL SCREENING TEST}

\section{GENERAL DIRECTIONS FOR TEST ADMINISTRATION}

The test 18 divided into two parts. Each part contains 25 Itens excluding sample or demonstration 1tems. This was done to provide a foroed rest or actirity period for youngsters this age since presohoolere are uneooustomed to an extended period of romal struoture.

1. Prior to the actual administration of the test the examiner should fanlliarize himself with the direotions for glving the test. A recomended practloe 18 for the exaniner to take the teat in the sane manner the pupils are expeoted to respond. The testing oan proseed with confidenoe and preolsion only if the examiner is well aoqualnted with the test materials and diseotions.

2. The test has been given to groups of ohlidren varying In group size from 18 to 72 youngsters. When the size of the group exoeeds 20 youngsters it 18 reoomm mended to have a second or thi rd person in the room to assist in general management and control of the group and in the distmbution and oollection of atade 
3. The ohlldren should be seated in such anner as to preolude oopjing. Th1s may be done through adequate spacing or provision of oardboard dividers to prevent Initat Ire behavior.

If sohool olassroon is used as the testing room, Instruotional materials and toys should bo placed In cabinets or covered to elminate stimulating or distracting itens from the physical environment.

4. The preclse wording of the direotions must be used to Insure proper administration. All direotions should be spoken slowly and distinotly in a olear, natural, pleasant roloe. The exaniner should stand in a central location where he can be observed by all the youngsters .

5. A few sample 1tema precede rarlous seotlons of the teat to assist the ohllaren in knowing what is expeoted of then. Ample time should be spent on these demonstration items to insure the joungsters' understanding of what to do and how to respond to the test 1tems. They should be bhom how to mark the uultiple oholoe itoms by maring a oross. A blackboard or orerheac projector can be used to demonstrate this and w11 G1ve the ohllaren some preotice in using penclis wth paper. Howerer, no assistance can be given an 
Indiridual onild onoe the regular part of the test is In progress.

6. Regular, colored, or primary peno1ls may bo used by the ohlldren to record thelr responses. The youngsters should be told to raise their hand if their peno1l breaks.

7. Lavatory needs should be attended to prior to the testing stuation or during the rest or actirity period. Should other energencles arlse they nay bo handled at the disoretion of the examiner.

8. Children should be told that during the teat perlods no one but the examiner or monltor may do any talking. No questions pertaining to the tegt should be answered during the testing perlod. If questions arl se ther should be answered with the following or simllar statement - "Do what you think 1s best".

9. The entire test 18 timed 1 ten by 1 tom but since $11 \mathrm{~b}$ eral t1me allowance has been provided, most joungsters should be able to finish each 1ten. No 1 tems should be onltted from the test and the full time limit should be allowed for eaoh Item to Insure that the disorininating power of the test 18 retained. The uac of a stop matoh is recommended. 
10. Blanks for the chlidren's names and other data may be completed prior to the distribution of the booklets. If each chlid is supplied with a name tag and number the booklets can be matched with each ohlld more eas11y.

11. Each test 1 tem 18 printed on a colored page contrastIng it from adjacent pages. This serves to stimulate and focus the attention of the chlldren and to fac111tate administration by acting as a cheok that everyone 18 on the right page.

12. The test is not graded in difficulty. The ohildren M11 hoperully find new momentum and motivation as they progress through the test alternating betreen a series of easier and more diffloult 1 tems.

13. It is Important at this age level to keep the onlldren enoouraged and reassured through the manner of presentation and attitude of the examiner. Inoluded in the spec1fle directions w11l be found several rerbal statements intended to encourage and reinforoe the test behavior of the chlidren.

14. Following each 1 tem the ohlldren must be reminded to tum to the next page by folding the completed page at the top. Some ch1ldren may need speolal assistance. 
Before glving instructions for a spec1flc 1tem the examiner should take time to survey the group to be sure all children are on the correct page. 
SPECIPIC DIPECTIONS POR TEST ADMINISTRATION

\section{PART I}

After the chlldren are properly seated, say: "Boys and g1rls, we are golng to play some games today with these booklets. (Hold up a booklet.) I an golng to give each of you one of these booklets and penall. Sit very quietly unt1l everyone gets one and then I w11 tell you how to play the games." D1stribute the booklets and penclls. Fold the cover page back at the top as you glve eaoh ohild hls booklet so the flrst sample 1tem is showlng.

G1ve the following speoirlo instruetions slowy and olear1y. As much holp as is needed may be given on the sample 1tems. Repeat the samples if deemed necessary. No special help can be given on the actual test items in finding the correct answer but ample encouragenent and reassuranoe may be offered at any tine to the group.

Sample 1. "Now, boys and glris, 11sten very oarefully as I tell gou what to do. Look at the plotures on this page. I an golng to tel.1 you to mark one of the plotures by drawing a cross on 1t, $11 \mathrm{ke}$ this. (Demonstrate on the blackboard, large ohart paper, or by aeans of the overhead projector.) Look at each ploture as I name 1t. (Name all the plotures beginning at the top of the page.) Alrplane - magon oar - boat. Nor, mark the car. (Pause) You should have 
drawn a cross on the picture of the oar. 11ke this."

(I1lustrate on the examiner's test booklet, holding $1 t$ slightly above the ohlldren's eye level so everyone can see $1 t_{.}$)

After completion of eaoh test 1tem, say: "Now, turn to the next page, the (nave the color) page I1ke this one." Check to see that each child 18 on the correct page. Assist any youngster having alfficulty finding the oorreot place before beginning specifio instmations.

Sample 2. "Listen carefully as I tell you what to do. Iook at the plctures on this page while I name each one. (Name all the pletures beginning at the top of the page.) Trousers - hat - dress - coat. Now, mark a oross on the dress. (Pause.) You should have dram a eross on the pletire of the dress, 11ke this." (Illustrate on the examiner's test booklet.)

On 1 tems one to twenty-five the examiner should pause ten seoonds after giving the directions. Then, the chlldren are told to turn the page in the manner mentioned previously.

1. "Look at all of the plotures. Mark the orange."

2. "Look at all of the plotures. Mark the envelope."

3. "Look at all of the pictures. Mark the etraw."

4. "Mark the one that wakes a tapping sound." 
5. "Hark the puddle." (After the ten seoond time limit but prior to telling the children to tum the page, make the rollowing statement.) "I see that all of you are doing a fine job. Keep up the good rork."

6. "Look at all of the pletures. Mark the gom."

7. "Maxik the animel that roars."

8. "Mark the eye that has erelashes."

9. "Look at all of the pictures. Mark the Juggler." (After the time 12mit explres but before tuming the page, make the following statement.) "That's fine. Remember to try your best."

10. "Mark the girl who rescues the kitten."

11. "Mark the mansion."

12. "Iook at all of the plctures. Mark the longest penonf

13. "Look at all of the numbers. Maxk the number $\underline{g} 1 \underline{\text {. }}$ That's 1t, mark the number Bix."

14. "Mark the shortest oandle."

15. "Mark the number flve." (Arter the time 1imit explres but prior to telling the ohildren to turn the page, make the following statement.) "I see that 211 of you are dolng a fine job. Keep up the good work."

16. "Listen careful1y. Mark the third raindrop below the oloud."

17. "Look at all of the letters. Mark a pross on the

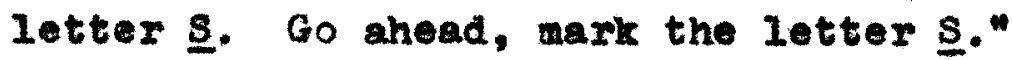


18. "Mark the letter ‥

19. "Mark the letter A."

20. "Mark the letter $0 . "$ (After the time 11m1t expires but prior to telling the ohlldren to turn the page, make the following statement.) "All of you seem to be dolng rery well. Remember to try your very best."

21. "Look at all of the plotures. Mark the ears that look 11ke the ears of a mouse."

22. "Mark the oolor of oogl."

23. "Mark the animal that is tame."

24. "Mark the anlmal that has feathers."

25. "Llsten carefully to that I say. Look at the ploture at the top of the page with the of rele drawn around 1t. (Point to 1t.) Now, find another ploture that looks just 11ke 1t and mark 1t. Go ahead. That's 1t, Find another ploture that looks just 11ke the one with a cirole around it and mark it with your penoll."

Colleot the booklets and peno1ls. Then, provide a short rest or activity period for the ohlldren. Give speolsl help to any ohild who was having diffloulty in marking the booklets. Have the chlldren attend to bathroom needs. Answer any questions whloh do not pertaln to questions asked on the test. Record comments on the booklet of any ohlld exhlbiting unusual behavlor. 


\section{PART II}

After the ohlldren are properly seated, say: "It's time to play some different games now. I am going to give each of you one of these booklets (hold up booklet) and another peno1l. S1t very quietiz unt1l erexyone gets one and then I w11l tell you how to play the games." Distribute the booklets and peno1ls. Fold the oovar page back at the top as you give each ohlld h1s booklet so the ample 1tem is showing.

Give the speolfio direotions slomly and distinctly. Generous assistance mas be given on the sample itens and they may be repeated if deemed necossary. Extra encouragement and reassurance may be offered at any time to the group but no help may be given in completing an actual test item oorreotly except the samples.

Sample. "Now, boys and g1rls, 11 sten very carefully as I tell you what to do. Iook at the line solng up and dom at the top of this page. (Point to vertioal line.) I want gou to make a I1ne just 11ke that one dom here. (Point to Iower section of page beneath the dividing line.) That's right. Go ahead and make a 11ne dom here just 11 ke the one near the top of the page. (Pause.) Now, watoh me. You should have made a line just like this. (Drar a rextioal Iine and hold examinex's booklet slightly above the ohlldren's eye level so everyone oan see 1t.) 
After the completion of each test 1tem, say: "Now, turn to the next page, the _____(name the color) page 11ke this one." Check to see that each ohlld is on the correct page. Assist any youngster having diffloulty finding the correct place before besinning specif10 instruetions.

Items twenty-81x to fifty call for a variety of responses.

The time limits rary on these 1 tems and are 11 sted following the Item number. Allow the preclse amount of time allooated to each 1tem.

Item Time

26 15" "Look at the picture of a olrole here. (Point to the 01rele.) Make one just like it but do 1 tom here. (Polnt to lower blank seotion of page.) That's right, make a clrcle on your paper."

2720 " "Look at the pleture of a trlangle here. (Point to the triengle.) Make one just $11 k$ it dom hexe. (Point to lower blank section of page.) That's right, make a trengle on your paper."

28 20" "Look at the square at the top of your paper. (PoInt to the square.) Make one just 11ke 1 t but do 1 to dom here. (Point to lower blank section of page.) Try the very best you can. Make a gquare on your paper." 
Itom Time

29 120" "On th1s sheet of paper I want you to make a ploture of a man. Make the very best ploture that you can. Take your time and work very oarefully. I want to see if you boys and girls can do as well as other onlidren have done. Go ahead. Try rery hard and see what good plotures of a man you can make." Answer all questions by saying, "Do materer you think 18 best." Walk around the room and observe the onlldren's work 1 thout oomment.

Sample. "Look at. all of the small squares on your peper. (Point to the squares.) I want you to mark one of the squares with your peno11. Go ahead. Mark one of the squares wth your peno1l. (Bause.) All of you should have one square marked with your penc1l. It does not natter wh1ch one you chose to mark. It could be any one, but only one should be marked 11ke th1s. (Demonstrate by marking one of the squares. Do 1t quiokly but not neoessarily neatiy.

Item Time

3020 " "Look at all of the squares on your paper. Hark three of the squares w1th your peno11. Go ahead, mark three squares only."

31 40" Repeat the directions in 1tem 30, but insert ten.

32 30" Repeat the dirootions in 1tem 30, but insert 81 . 
Item Time

$3340^{\circ}$ Bepeat the al rections in 1tem 30, but insert nine.

$3430^{\prime \prime}$ Repeat the disections in 1 tem 30 , but insert seren. (After completion of the 1tem but before tuming the page, make the following statement.) "I see that all of you are dolng a fine job. Keep up the good work."

$3515^{\prime \prime}$ "Look at all of the different designs on this page. Mark all of the plotures of a diamond. That's it, mark a oross on all of the diemond-shaped designs."

$3690^{\prime \prime}$ "Nor I want you to print your name on this sheet of paper. Do it here. (Polnt to the ines in the middle of the page.) Print both your f1rst and 1ast name 11 you can. Go ahead. Do the best you oan. That's 1t, print your name as best you can."

37 10" "Look at the balls. There are three of them. (Polnt wille counting.) one, two, three. Now, I want you to make the number three on your paper. Go ahead. Make the number three on your paper."

38 10" "Look at the buttons. There are nine of them. (Point while oounting.) One, two,... nine. Now, I want you to make the number nine on your paper. Try the best you can. Make the number nine."

39120 " "Look at all of the dots and numbers on this page. Start with number one and draw a I1ne to number two. As you count the numbers in order draw a line to 
connect the numbers. When you are rinished you w111 have a pleture of the head of an Indian Chlef. Remember, as you count from one to twenty, dran a line to connect the numbers."

Sample. "This 11ttle boy lives here (pointing to the figure on the path, and here (pointing) is his grandmother's house. The 11ttle boy wants to go to h1s grandmother's house the shortest way without getting of the sidewalk. Here is the sidewalk. (Point to the path where the boy stands.) Shor we the shortest way for the 11 ttie boy to go to his grandmother's house. Mark it wth your peno11, but do not go off the sidewalk. Start where the little boy is (point) and take him to his grandmother's house (polnt) the shortest way. (Pause.) You should have dram a 11ne from the little boy to his grandmother's house, like this. This is the shortest way **

Item Time

40 20" "This 11ttie boy 11ves here (point), and here (point) is his grandnother's house. The little boy wants to go to his grandmother's house the shortest way without getting off the sidewalk. Here is the sidewalk. (Point to the path were the boy stands.) Show me the shortest way for the little boy to go to h1s grandmother's house. Mark it with your peno11, but 
do not go off the sidewalk. Start where the 11ttle boy is and take hig to his grandmother's house the shortest way."

$4120^{n}$ "This little boy lives here (point). Show mo the shortest way for him to go to his grandmother's house (point). Mark 1t with your penoll but do not go off the sidewalk."

$4220^{\prime \prime}$ Repeat the directions in 1 tem 41.

43 10" "Look at all of the plotures. Mark the one which 18 nade of glass."

44 10" "Mark the one that swing in water."

45 10" "Mark the one that 18 gharg," (After the time ilmit explres but prior to telling the chlldren to turn the page, make the following statement.) "That's fine. Remember to try your best."

Sample. "Look at the ploture at the top of the page. (Point to 1t.) A very important part is gone in the ploture. See If you can find the part that is gone but do not say anything out loud. (Pause.) Now, look at the other plotures of things that might be gone. (Name the possible missing parts beginning with the top one.) Now, mark the picture of the part that 18 missing from the bis ploture at the top.: Only mark one of them. (Pause.) You should have marised the ploture of the mouth, like this. (IIlustrate on the examiner's test booklet.) The part that is gone 
from this bis ploture (point to it) is the mouth, so that 18 why you marked the ploture of the mouth dom here (point to 1t)."

Item Time

$4615^{\text {" }}$ "Look at the ploture at the top of the page. (Point to 1t.) A very importent part is gone in the ploture. See if you can rind the part that is gone but do not say anythins out loud. (Pause.) Now, dom here (point to lower part of the page) have plotures of things that might be gone. Look at them and mark the one that is gone from the bis ploture at the top of the page. Only mark one of them."

$47 \quad 15^{\prime \prime}$ Ropeat the direotions in iten 46.

$481^{\prime \prime}$ Repeat the directions in item 46.

49 15" Ropeat the directions in 1 ter 46.

$50 \quad 15^{\prime \prime}$ Repeat the direotions in item 46.

Colleot the test booklets and penolls. Record ooments on the booklet of any chlld exhlbiting unusual behavior. 
DI RECTIONS POR SCORING

\section{PAPR I}

Each oorrect response on Part I of the test recelves a score of one polnt. Additional polnts may be obtained. An explanation of bonus polnts w11l be found following a speciflc sequenoe of 1tems. To soore a polnt the onrrect response on each test item mugt be marked with a cross or in some other manner which olearly indicates the subjeot's cholce. If another mode of response is used spontaneously in place of a oross, the fallure to follow direotions should be noted. If more than one response is marked for a single test iton, no response is indioated, or the inoorrect response is celeoted, no credit is given and the 1 tem recelves a soore of zero.

\section{Comreot Response}

\begin{tabular}{cllc} 
Item & Position & Description & Score \\
\hline 1 & second & orange & 1 \\
2 & f1rst & envelope & 1 \\
3 & second & straw & 1 \\
4 & second & tapping sound (drum) 1 \\
5 & fourth & puddio & 1 \\
6 & first & sown & 1 \\
7 & third & roars (11on) & 1
\end{tabular}




$\begin{array}{rlll}8 & \text { seoond } & \text { eyelashes } & 1 \\ 9 & \text { lower left } & \text { jusgler } & 1 \\ 10 & \text { lower left } & \begin{array}{c}\text { glrl who resoues } \\ \text { kitten } \\ 11\end{array} & 1 \\ & \text { upper right } & \text { nension } & 1\end{array}$

1-11 If nine of these items are correot, add one point to the ch11d's soore; if ten or more osrest, add two polnts.

$\begin{array}{llll}12 & \text { seoond } & \text { longest penc11 } & 1 \\ 13 & \text { third } & 6 & 1 \\ 14 & \text { third } & \text { shortest candie } & 1 \\ 15 & \text { seoond } & 5 & 1 \\ 16 & \text { third } & \text { third ratndrop } & 1 \\ 17 & \text { fourth } & \text { i } & 1 \\ 13 & \text { sixth } & \text { A } & 1 \\ 19 & \text { first } & \text { A } & 1 \\ 20 & \text { third } & 0 & 1\end{array}$

17-20 If three or more of these 1tems are correot, add one polnt to oh11d's soore.

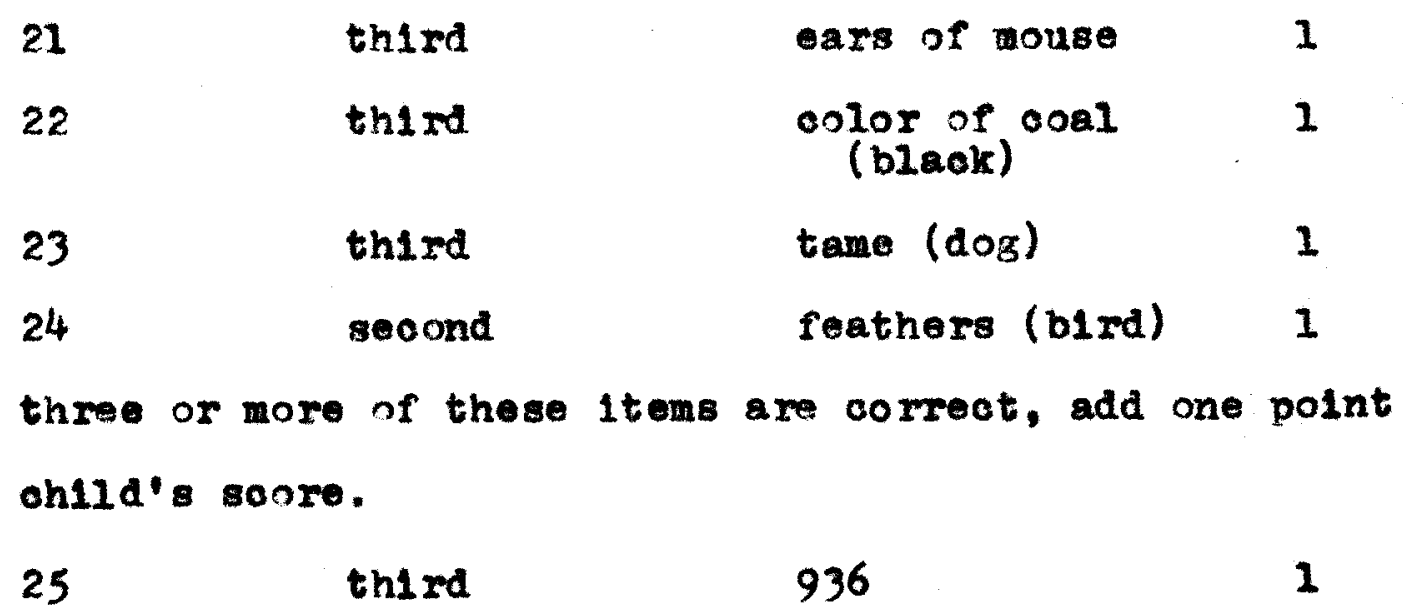




\section{PART II}

26. Copyine a cirole

The reproduotion should be approximately round and comDletely olosed. An ellptloal shape is acoeptable if the longer diameter is less than one-and-one-half the length of the smaller alameter. Extra lines used for closure, pointedness, angulation or sketohing are unaccoptable. The drawing must appear on the lower portion of the page to preolude traoing. If two or nore shapes are dram, all of them must meet the given specifications. S1ze is not oonsidered in the sooring. Soor one point for good approximation of a olrole.

Examplas of plus and minus olroles are 11lustrated in ploure 1 to fac1litate sooring. Although some of the minus examples have more than one error, anj of the following defoots alone would render the reaponse unacoeptable.

Example 1: Extre 11ne used for olosure.

Example 2: Extra 11ne alstorts olroular shape.

Example 3: More amorphous than olroular shaped.

Example 4: Elongation of proportions (longer dianeter more than one and one-half times blgger than shorter diameter).

Erample 5: Polntedness.

Example 6: Laok of closure. 


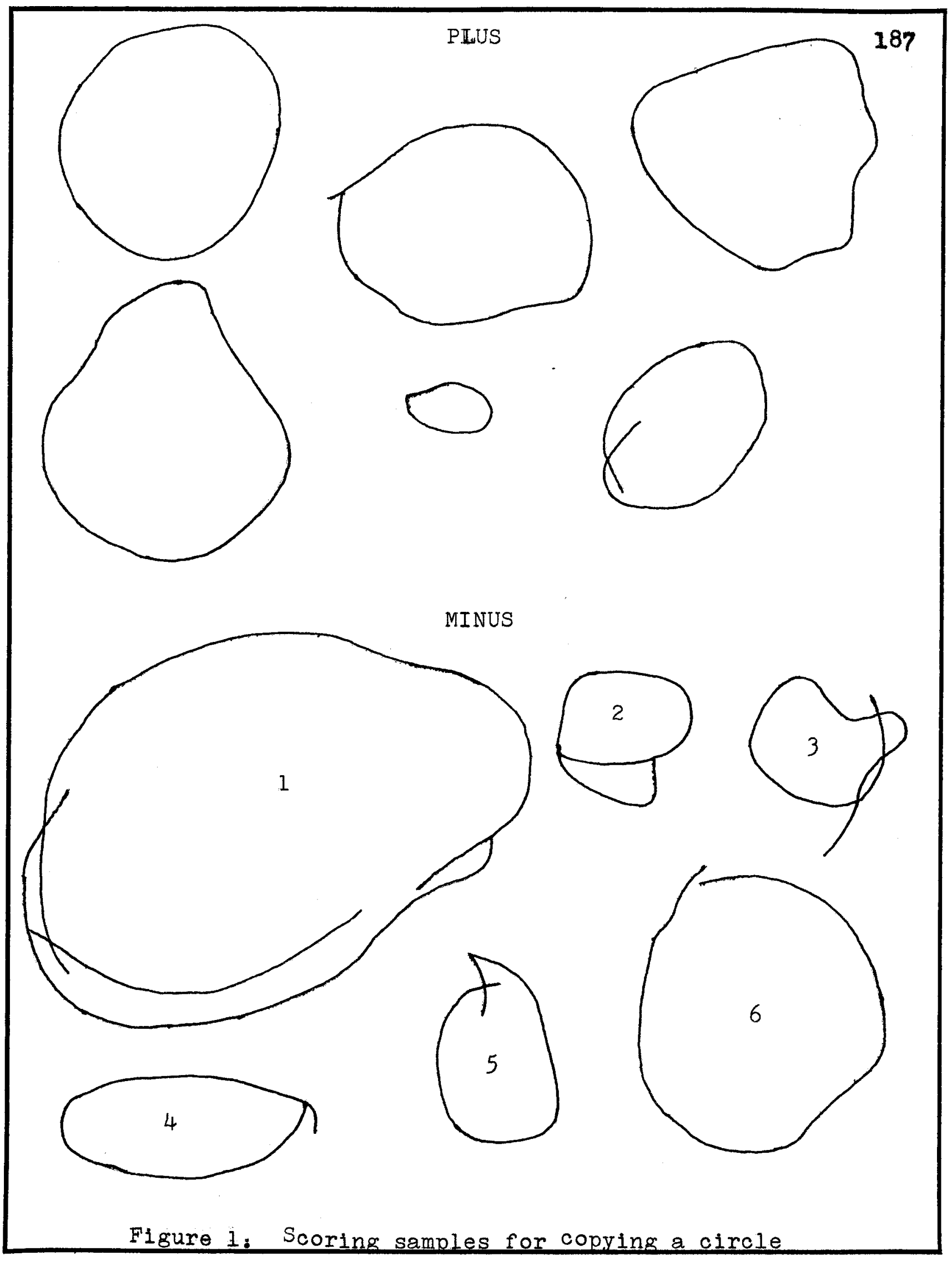


27. Copying a Triangle

The reproduction should have three well-defined angles but need not be equilateral. The lines should tend to be stralght although a slight unerenness is allowed. Curved, jagged or broken 11 nes are unecoeptable. Rounded corners, elongation of both lines at a cormer in excess of one-quarter of an 1nch, or additions of extra lines are unacceptable. The edge of the paper or dividing line on the paper may not be used as one side of the triangle. Size is not a sooring factor. If acoeptable, score one point.

Plgure 2 offers some samples of plus and minus sooring of the triangle.

Example 1: Rounded comer; elongation of both lines at the two bottom comers in excess of a quarter of an Inoh.

Example 2: Curved and broken 11nes.

Example 3: Broken 11ne.

Example 4: Top angle distorted.

Example 5: side angle missing.

Example 6: Curved and jagged 11ne; distorted ansle.

28. Copying a Square

The reproduction should approximate the proportions of a square but a rectangular drawing 18 acoeptable if the length does not exceed twice the width. The lines should tend to be stralght although slight unerenness is allowed. Curred, 


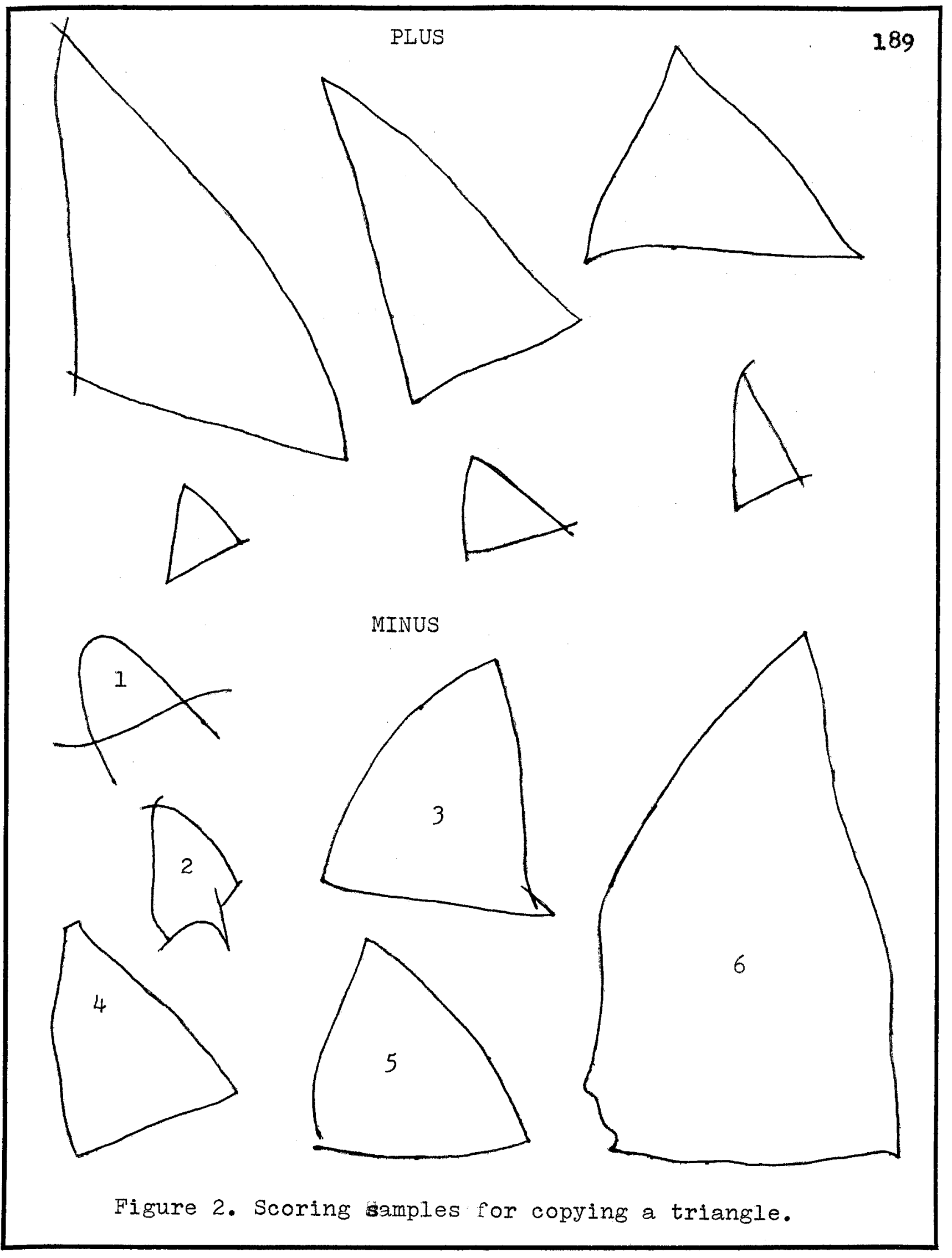


gagged or broken lines are unacoeptable. The four angles must be present and outstanding. Rounded corners, elongations of both lines at a corner in excess of one-quarter of an Inoh, or additions of extra IInes are unaoseptable. The edge of the paper or the dividing line on the paper may not be used as one of the sides of the square. S1ze is not a sooring factor. In order to recelve soore of one point, the drawing must have four well-defined angles, relatively stralght sldes, and resemble a square moro so than some other type of geometrio figure. If any one of the above mentioned unacoeptable responses is contained in the draning, a soore of zero is indicated.

Plus and minus examples of squares are demonstrated in Figure 3.

Example 1: One angle nissing; another angle distorted due to ourved I1nes.

Example 2: Extra lines; sketohed lines.

Example 3; One angle distorted; broken line. Example $4:$ Extra lines distort square shape. Example 5: Distorted angles; curred, broken, and jagged IInes.

Example 6: Hounded oomer; Jagsed ine.

26-28. If two or more of these 1tems are correotly reproduced, add one polnt to the ohild's soore. 


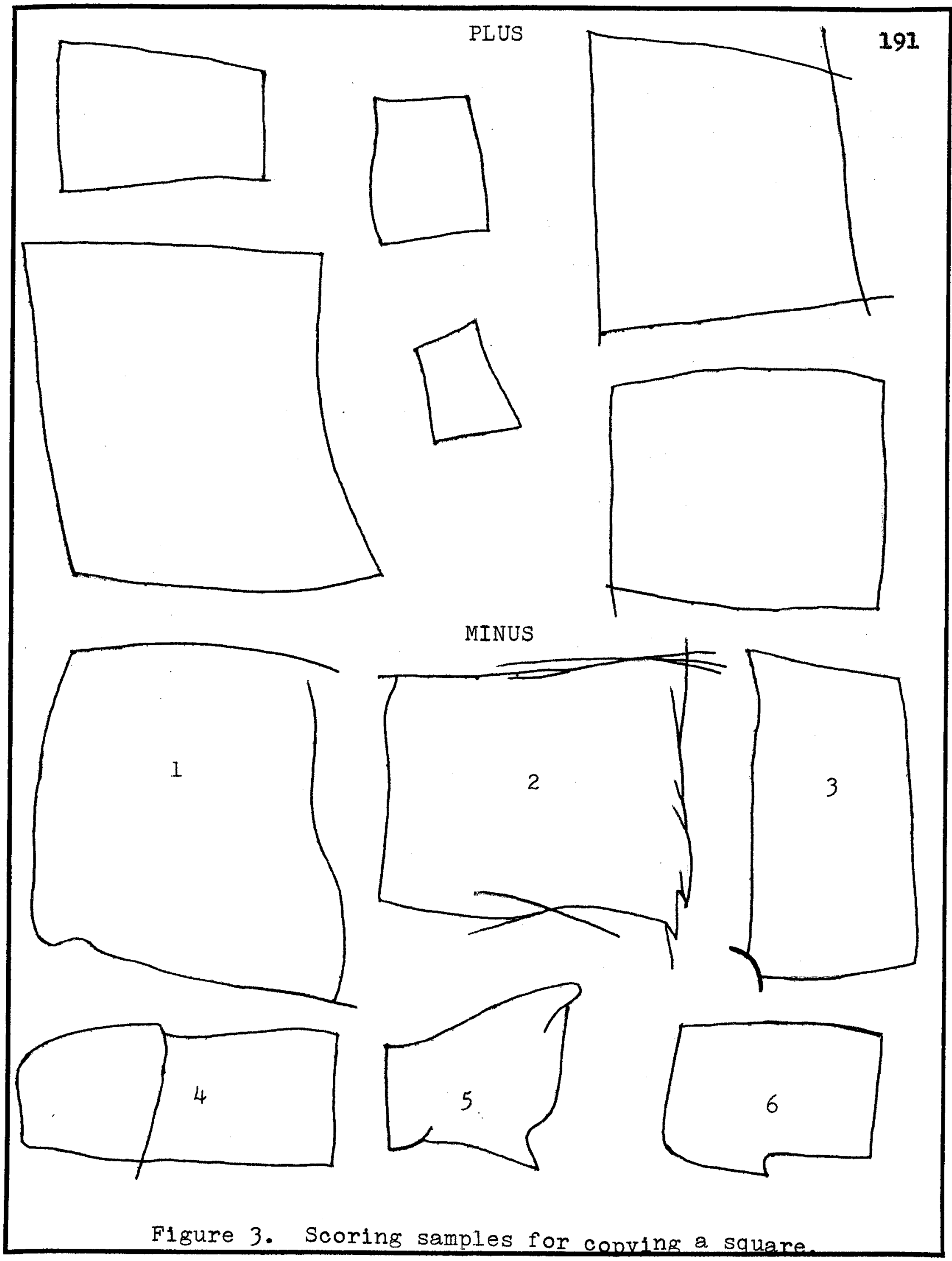


29. Human Figure Drawing

Score one point for each of the following parts of a person that are present in the oh1ld's drawing.
A. EEAD.
B. MOUTH.
C. NOSE,
D. EYES.

E. EYE DETAIL.

P. HAIR.

G. EARS.

H. LEGS.

I. ABMS.

J. TEUNK.
Any clear representation is aooeptable. Any olear representation is acceptable. Any olear representation is aoceptable. Any method of representation is acoeptable and the number need not be correot Any olear representation in which an ejobrow or eyelashes are shown is acceptable.

Any olear representation is acceptable. Any olear representation is acoeptable, but two ears must be present in a rull face drawing.

Any clear representation $1 \mathrm{~s}$ acoeptable, but the number must be oorreot. Any clear representati on is acoeptable, but the number must be oorreot. Ang olear Indioation 18 acoeptable, Inoluding stralght line.

K. IENGTH OF TBURK GRRATER THAN BREADTH.

Measurements must be taken at polnts of greatest length and breadth. A single Ilne does not recelve eredit. 
I. NECK.

H. PINGERS.

Any olear Indication is acceptable. Any clear indication 18 acceptable. Plngers must be show on both hands if both hands are present. Credit is given for fingers on one hand if only one is shom.

N. MUMBER OF PINGEBS.

PIve fingers must be present on both hands.

F1gure 4 offers 111ustrations of figure arawings to be used for practioe in scoring test 1 tem 29.

29. $A-N$

If a soore of seren to nine is achleved on these 1 tems, add one point to the ohlld's soore. If ten or more are oorreot, add two points.

30-34. Number Concepts

30. Any three of the trelve squares must be marked clearis in some manner to be coceptable. If fever or more squares are marked it 18 uneooeptable. Soore one polnt if it meets the standard, otherwise zero.

31. Any ten of the twelve squares must be marked olearly in some menner to be acceptable. Score one polnt if correet. othezw1se zero. 


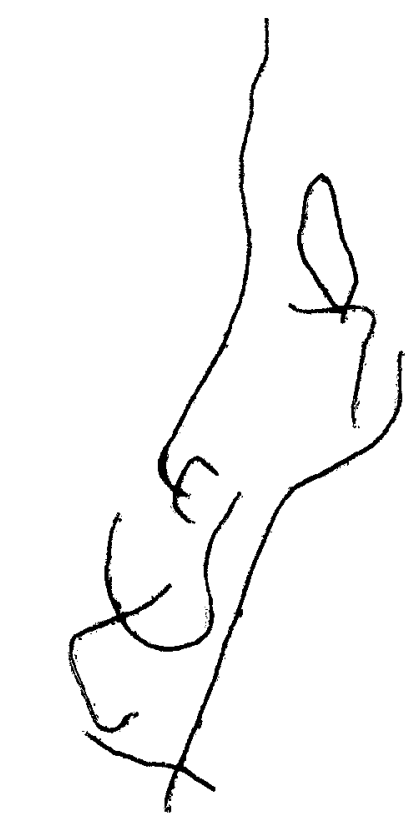

NO CREDIT

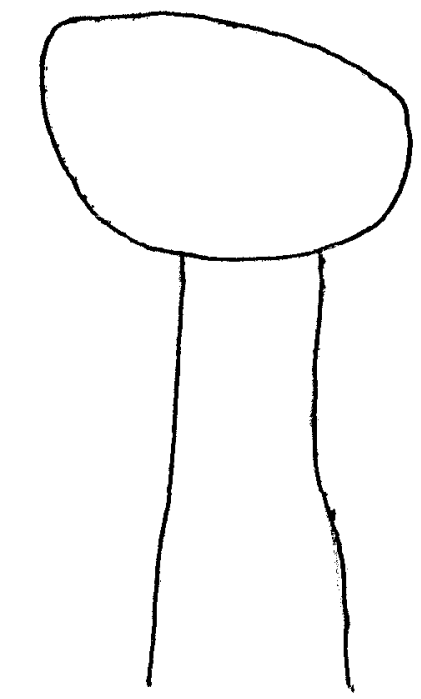

TWO POINTS
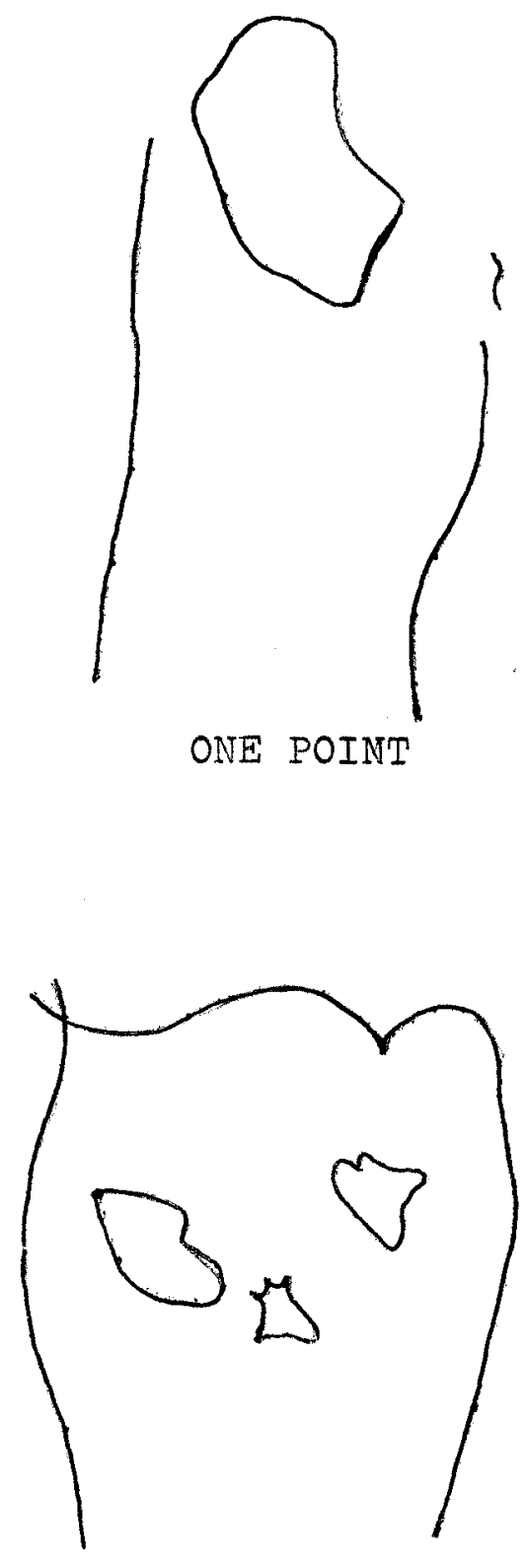

THREE POINTS

Figure 4. Sample figure drawings produced by four and one-half year old children. 

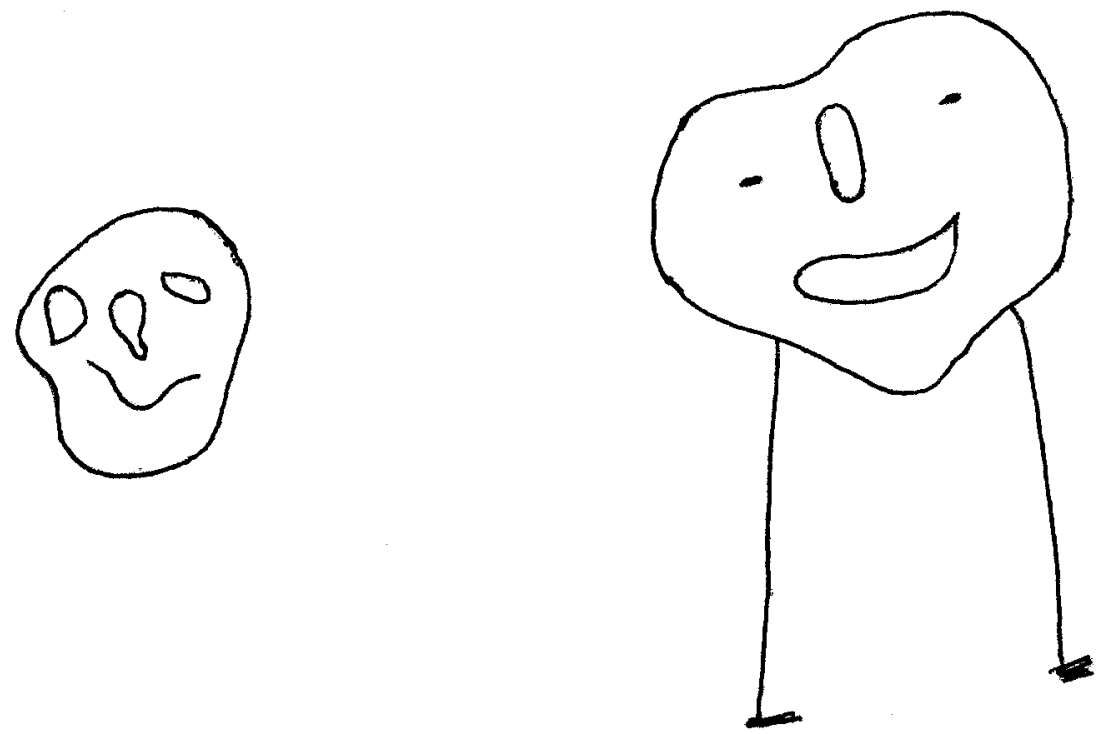

FOUR POINTS

FIVE POINTS
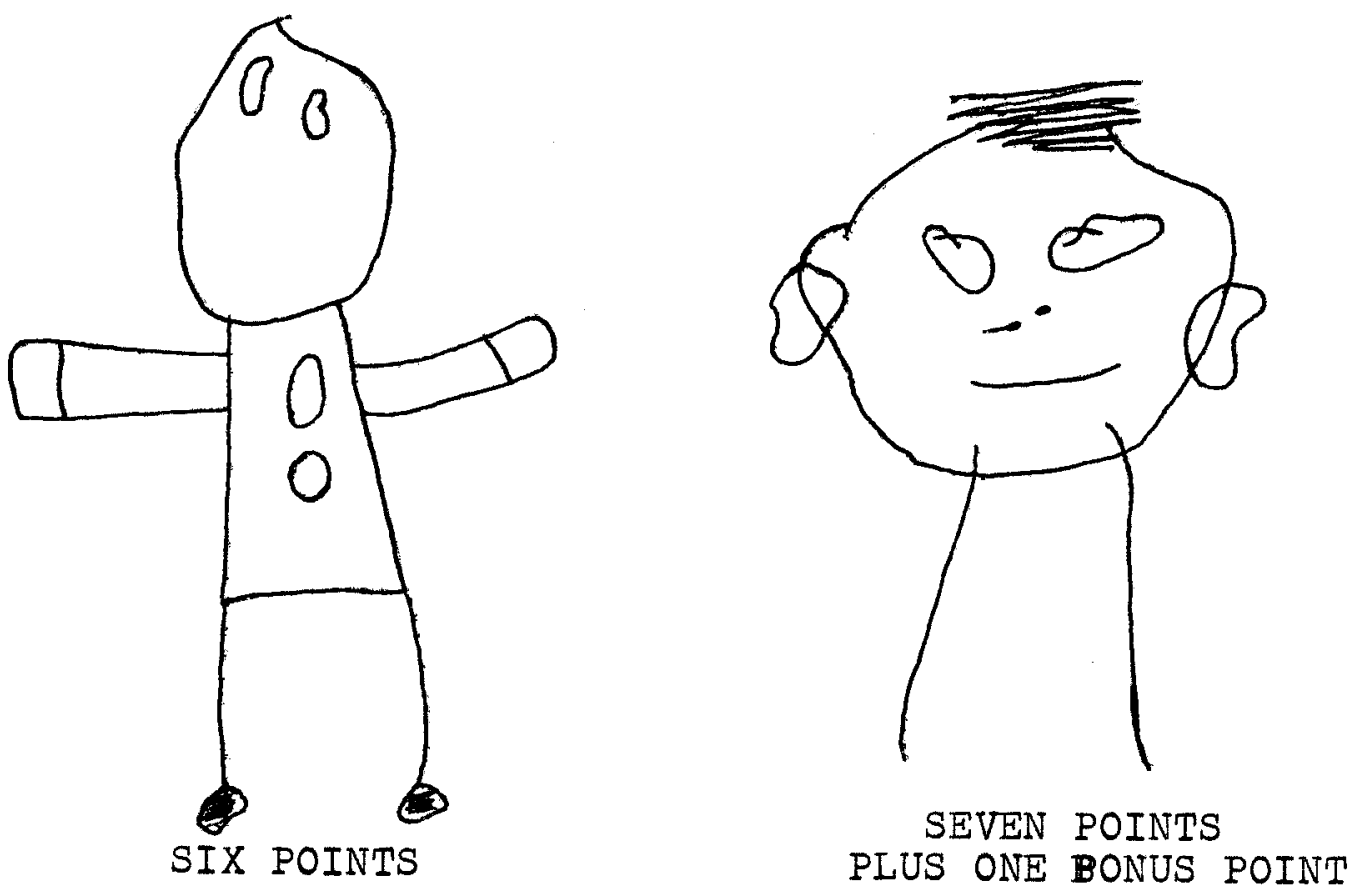

Figure 4. (cont'd). Sample figure drawings produced by four and one-half year old children. 


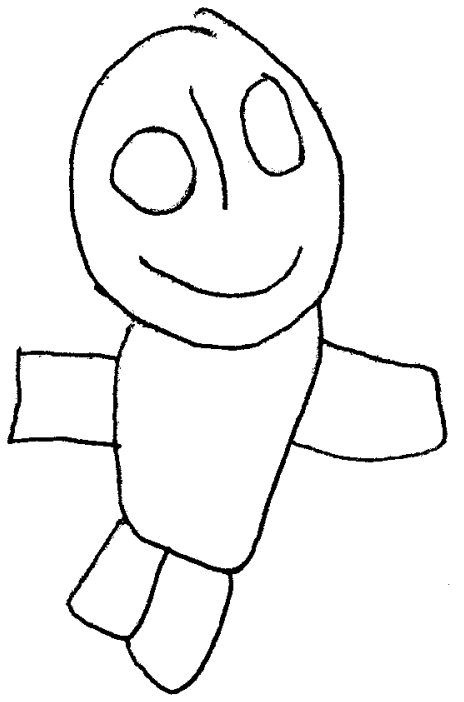

EIGHT POINTS

PLUS ONE BONUS POINT

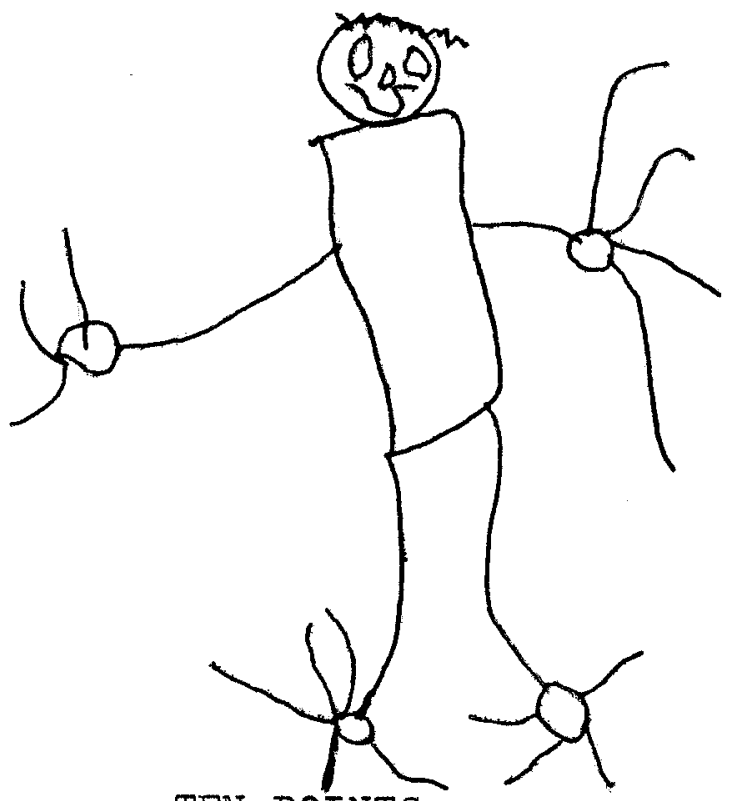

TEN POINTS

PLUS 2.10 BONUS POINTS

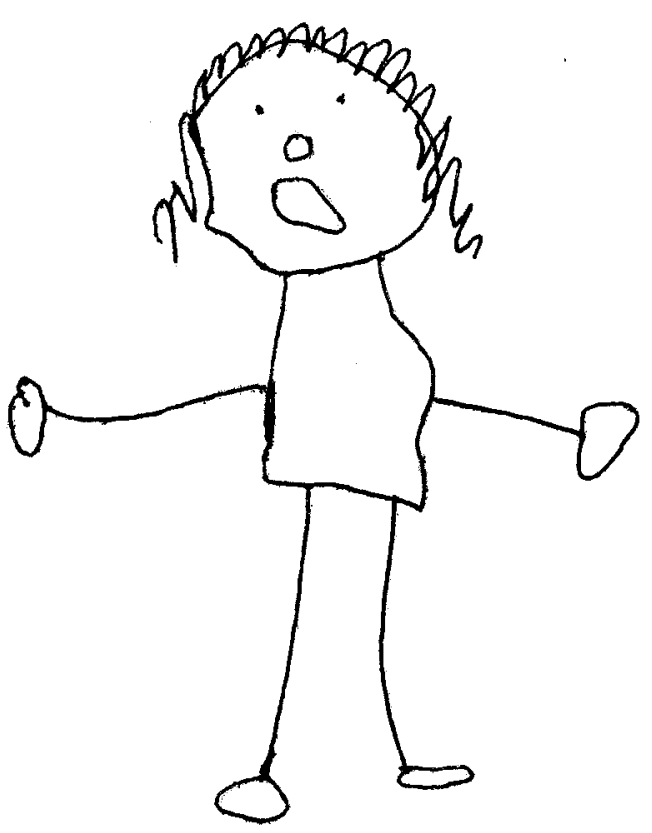

NINE POINTS

PLUS ONE BONUS POINT

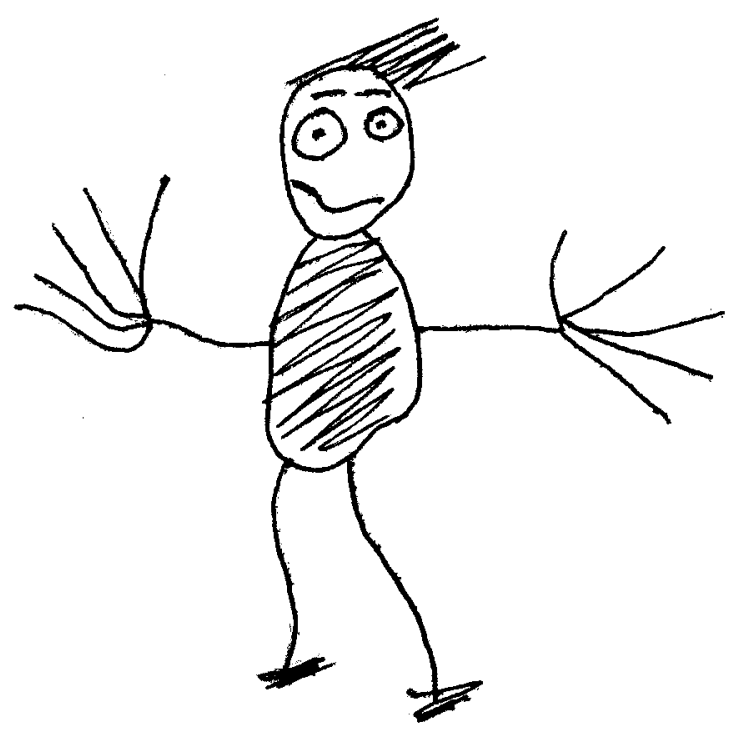

ELEVEN POINTS

PLUS TIO BONUS POINTS

Figure 4 (cont'd). Sample figure drawings produced by four and one-half year old children. 
32. Any s1x of the trelre squares must be marked to be acceptable. Senre one polnt if correot, otherwise zero.

33. Any nine of the twelve squares muzt be marked to be acoeptable. Seore one point if correct, othermse zero.

34. Any seren of the twelve squares must be marked to be aoceptable. Soore one point if correot, otherwlse zero.

30-34. If four or more of these 1tems reoelve oredit, add one point to the ohlld's score.

35. Rooognizing Geonetrio Designs

All three diamond-shaped flgures must be marked in order for the child to rooelve one polnt eredit. If all three diemonds are not marked or if any other designs are marked, no oredit is given.

36. Printing Nane

If less than three letters are printed, no oredit is given. (Exception: If two letters form a name, auch as ED, oredit is given for complete first name.) Three or more letters legibly printed in oorrect sequenoe reoelves one point orodit. Reversals and transpositions of letters or rotations of letters in excess of 45 degrees may not be included when adding the number of correotiy printed letters to determine the soore. The complete first name or niokname legibly printed in comeot sequenoe recelves two points 
credit regardless of number of letters. Score flve points for correct order and legibli1ty of first and last name, permitting one error of any kind.

37-38. Printing Numbers

37. The number three must be legibly printed to receive a soore of one point. Reversal or rotation in excess of 45 degrees is sonred zero.

38. The number nine must be leglbly printed to recelve a soore of one point. Reversal or rotation in excess of 45 degrees is soored zexo.

37-38. If both 1toms recelve credit, add one point to the child's score.

39. Connecting Dots in Numertcal Sequence

A drawing in whioh no errors are evident recelves a soore of three points. If no more than 11 ve errors are present and the drawing bears a resemblance to an Indian Chier, score one point. Eaoh additional or onltted ilne is counted as an error, as well as each violation of sequence.

40-42. Maze Tracing

A score of one point 18 oredited for each maze if the shortest path 18 selected. The line dram by the subjeot should be more within the boundarles of the path than outs1de 1t. Traolng one of the boundary 1 ines 18 permitted. 
40-42. If two or more of the 1tems recelve oredit, add one point to the chlla's score.

$$
\text { Position }
$$

43-45. Ploture Definstions

43

f1rst

44

45 flret

thend
Desoription

glass (window)

sw1ms ( $(21 \mathrm{gh})$

sharp ( $\mathrm{kn} 1 \mathrm{fe})$
Seore

1

1

1

43-45. If all three of these 1tems are correot, add one point to the ohlld's soore.

46-50. Mult11ated P1otures

46

47

48

49

50 thind

fourth

seoond

thind

second telephone recelver 1

triogcle wheel

person's ear

shoe lece

kitten's oar
1

1

1

1

46-50. If four or more of these 1tems are correct, add one polnt to the ohlld's soore. 
Number

FOR RESEARCH PURPOSES ONLY

EARIY ENTRANCE TO

KINDERGARTEN TEST

PART I

Name

Sex

School

Date of Testing

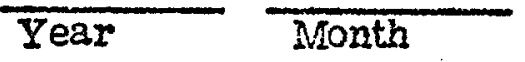

Day

Date of Birth

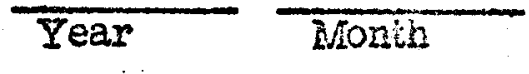

Day

Child's Age Yrs.

Mos.

*

*

氺

$*$

Total Score

Cut off point

Individual Evaluation Recommended

$*$ \$ \$ \$

Prepared by:

A. Edward Ahr

School Psychologist

School District 68

Skolkie, Illinois

First Revision

May - 1865 



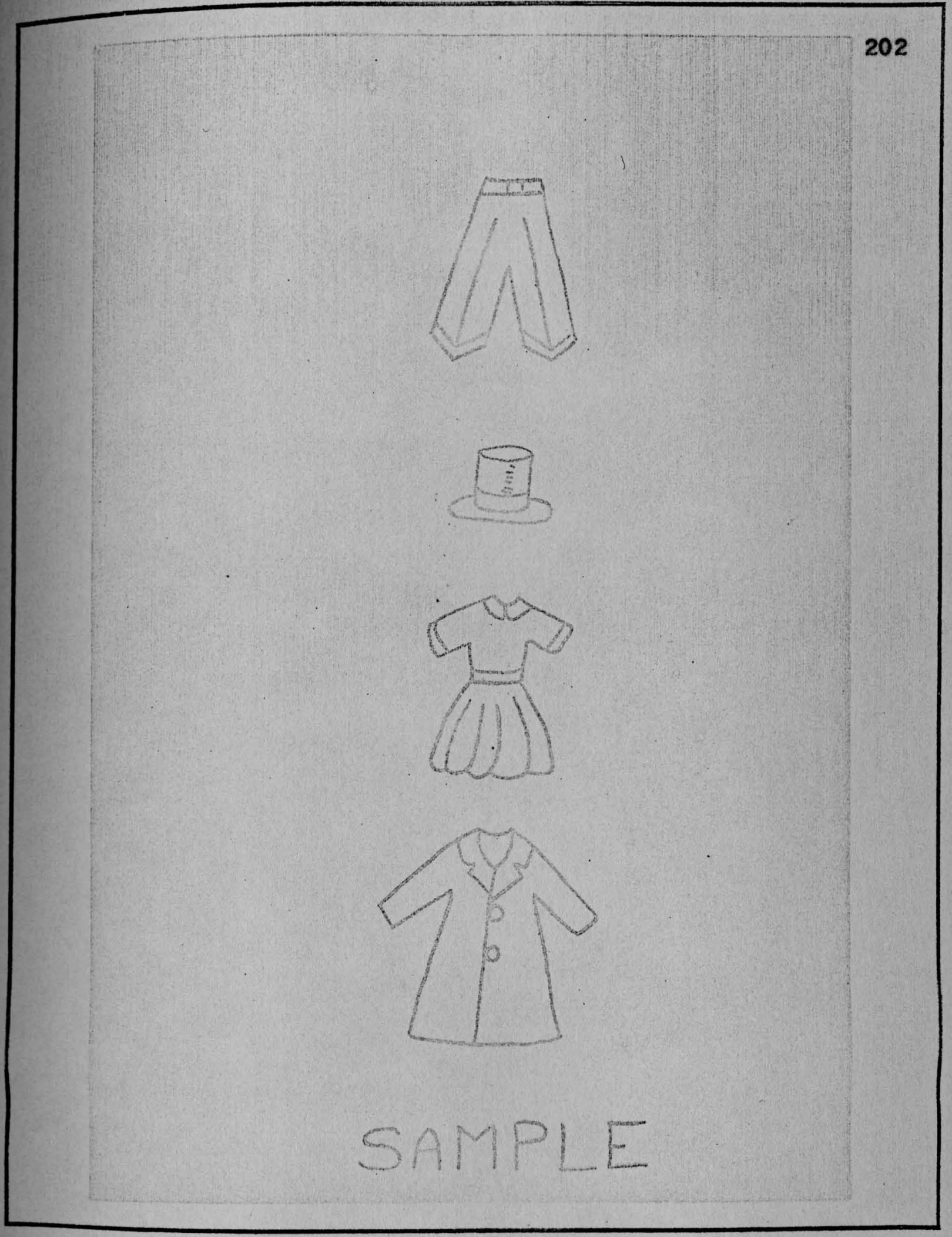




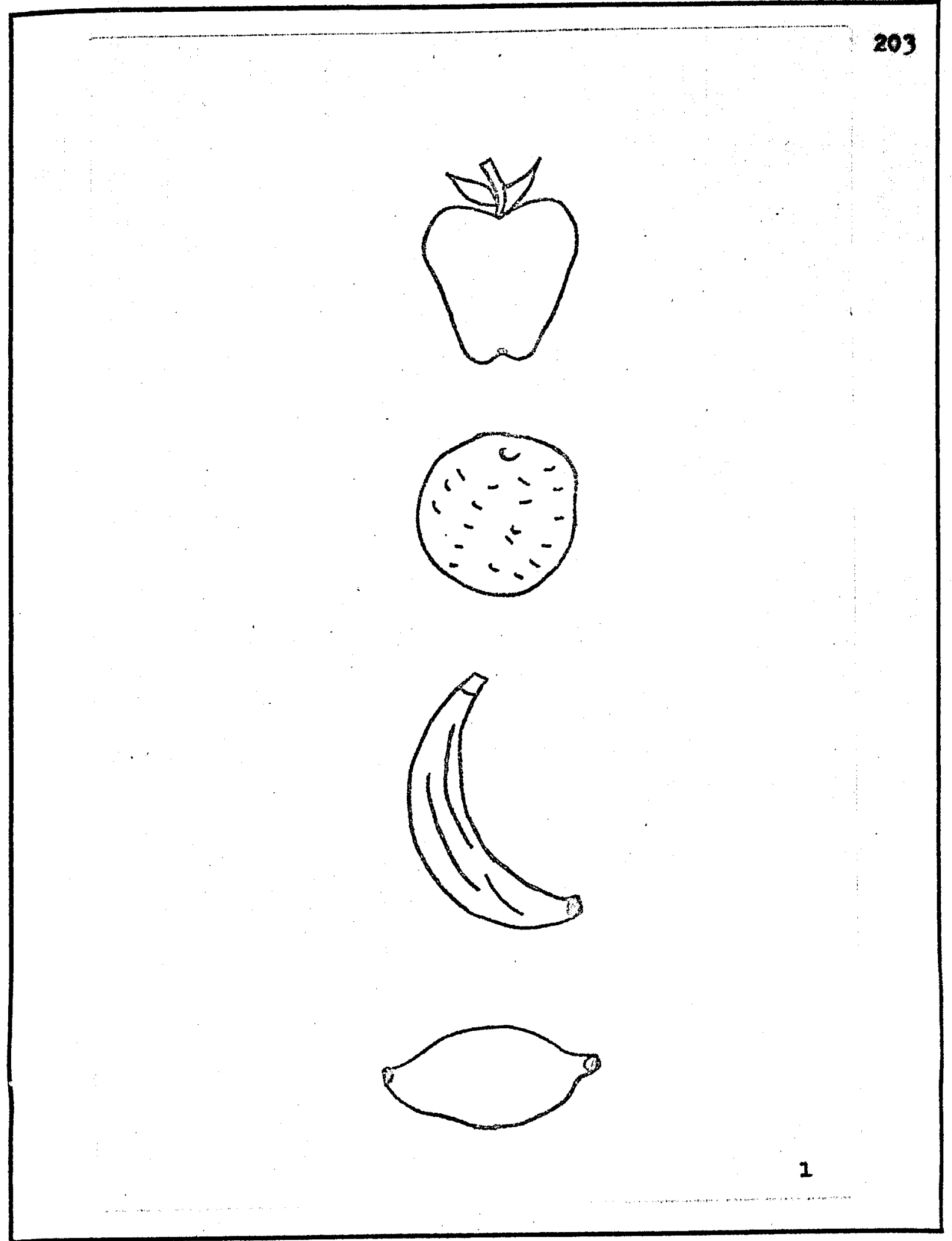




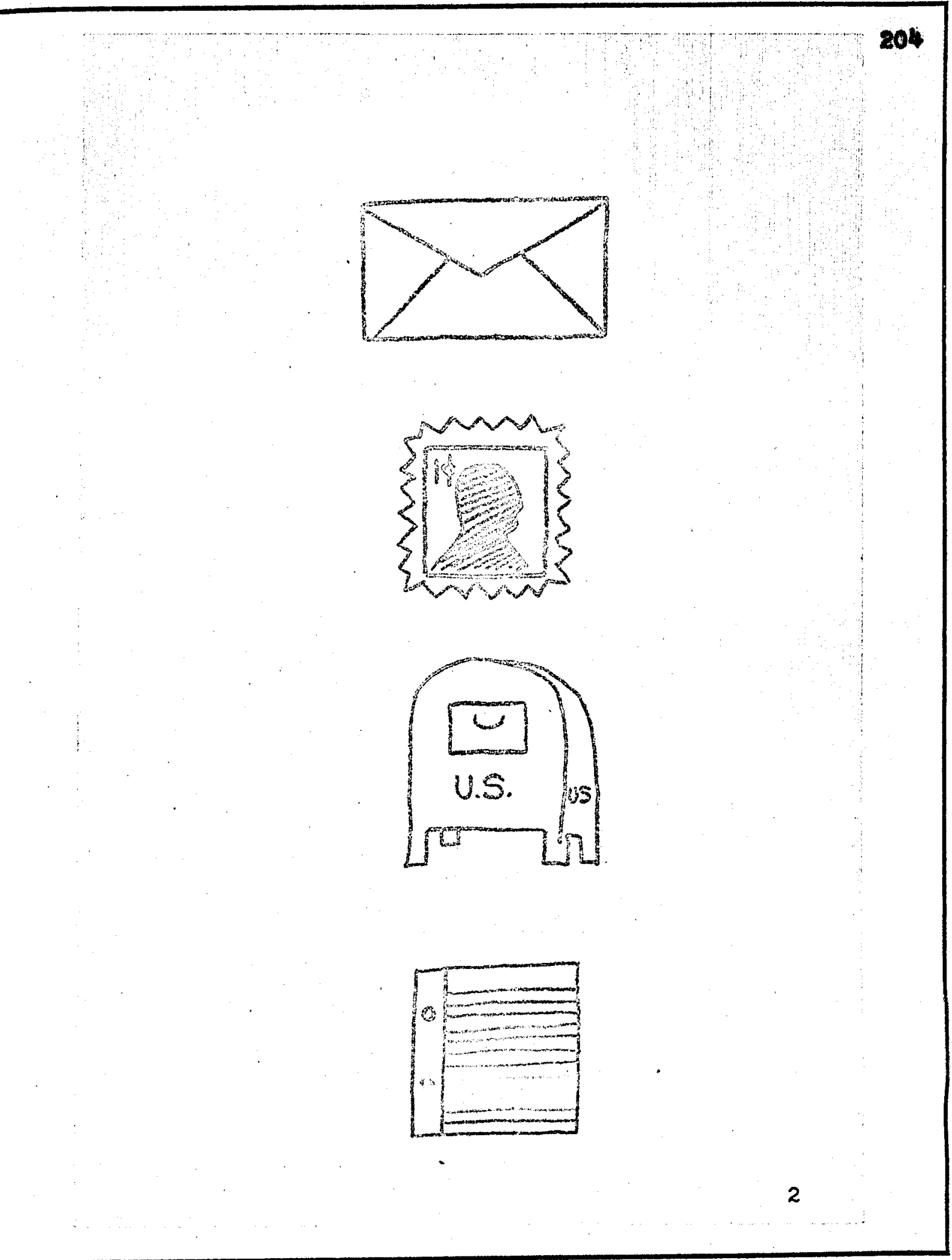




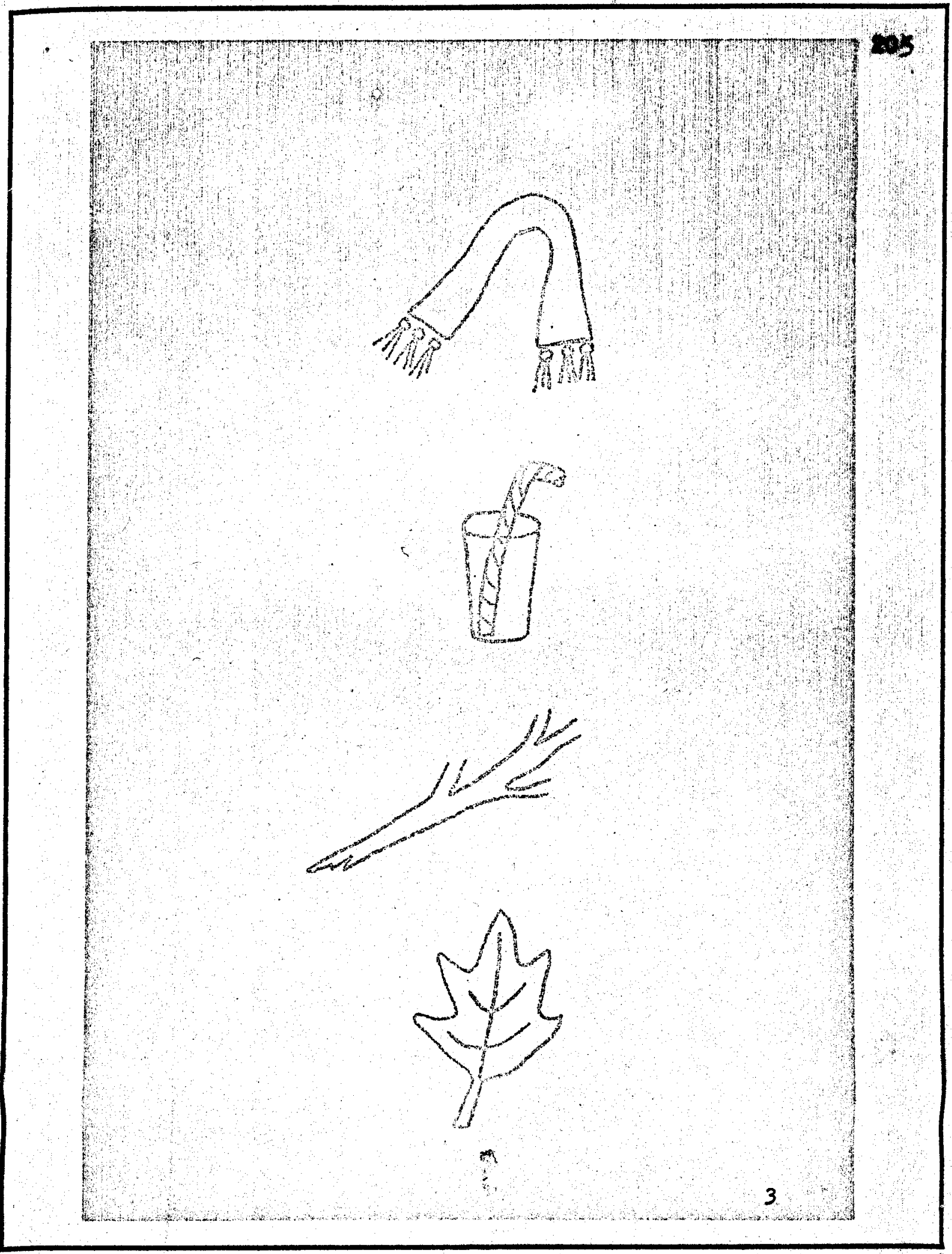




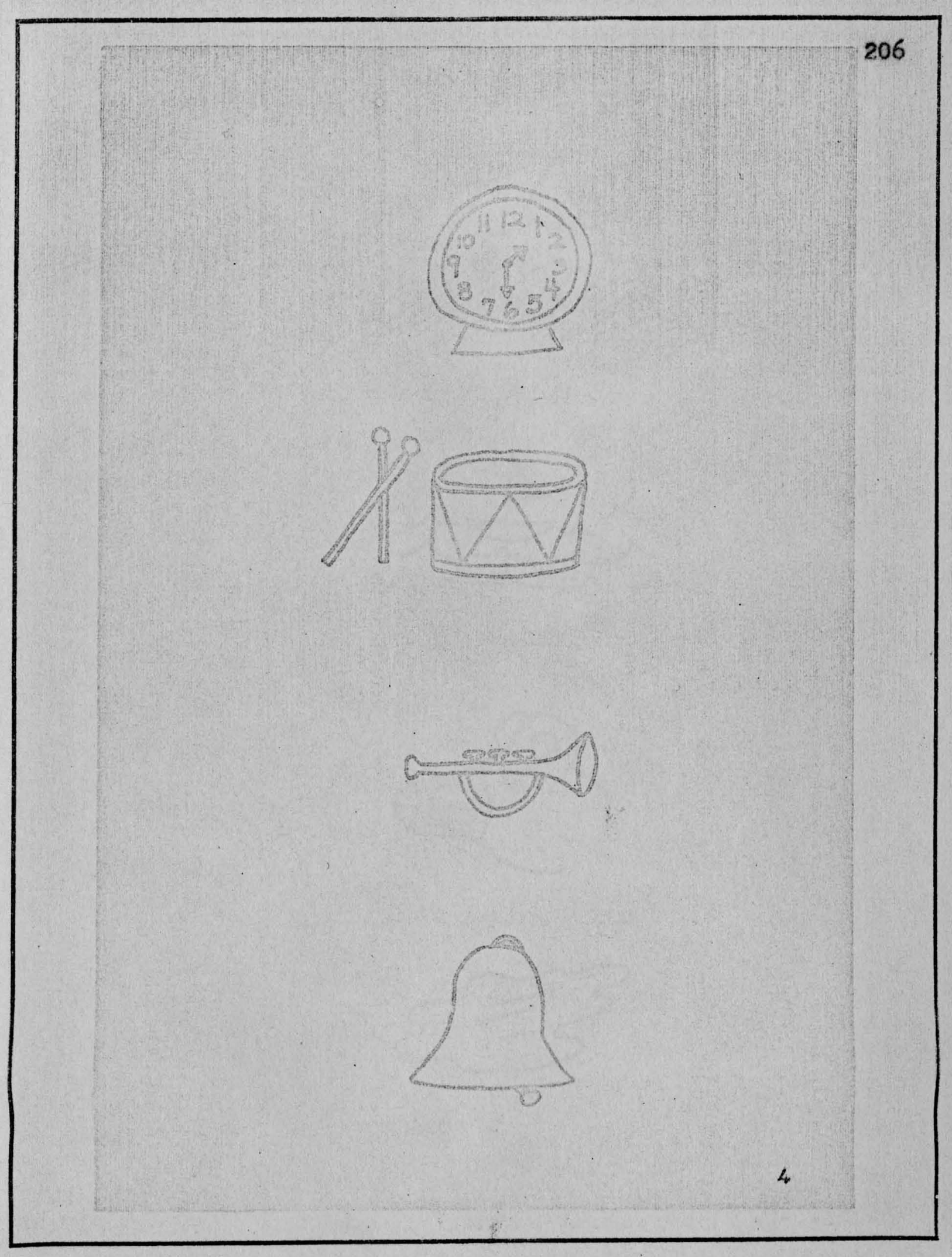





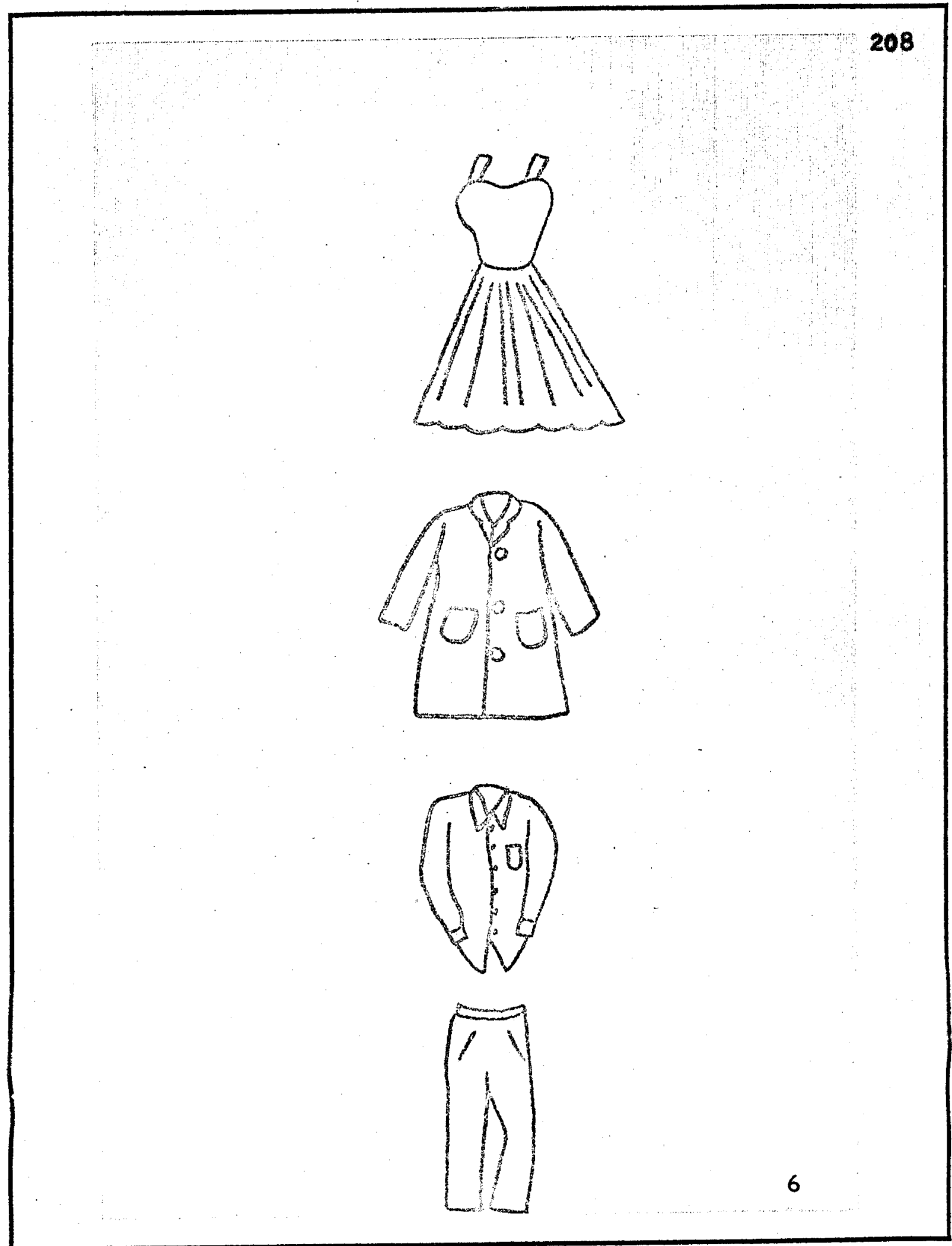




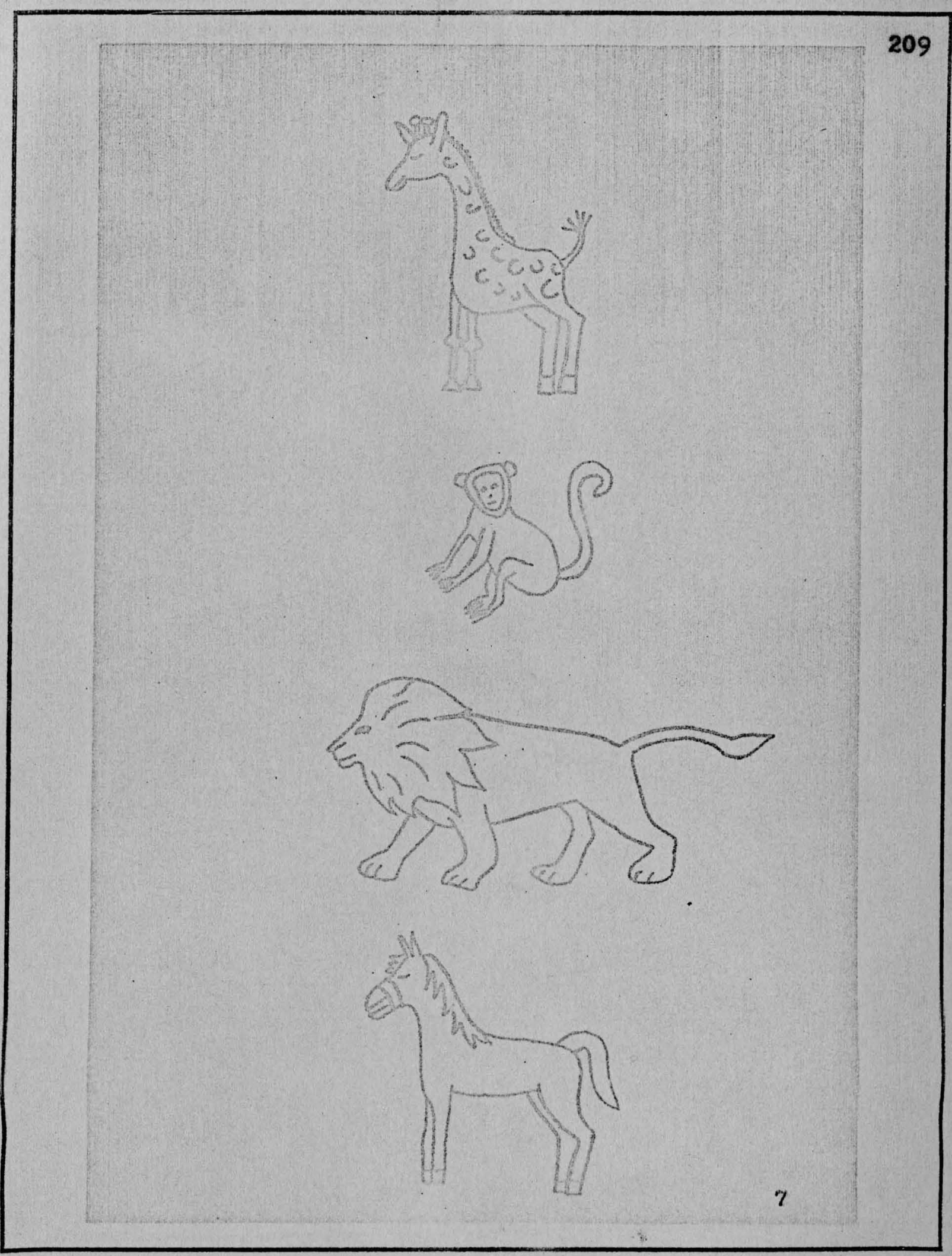




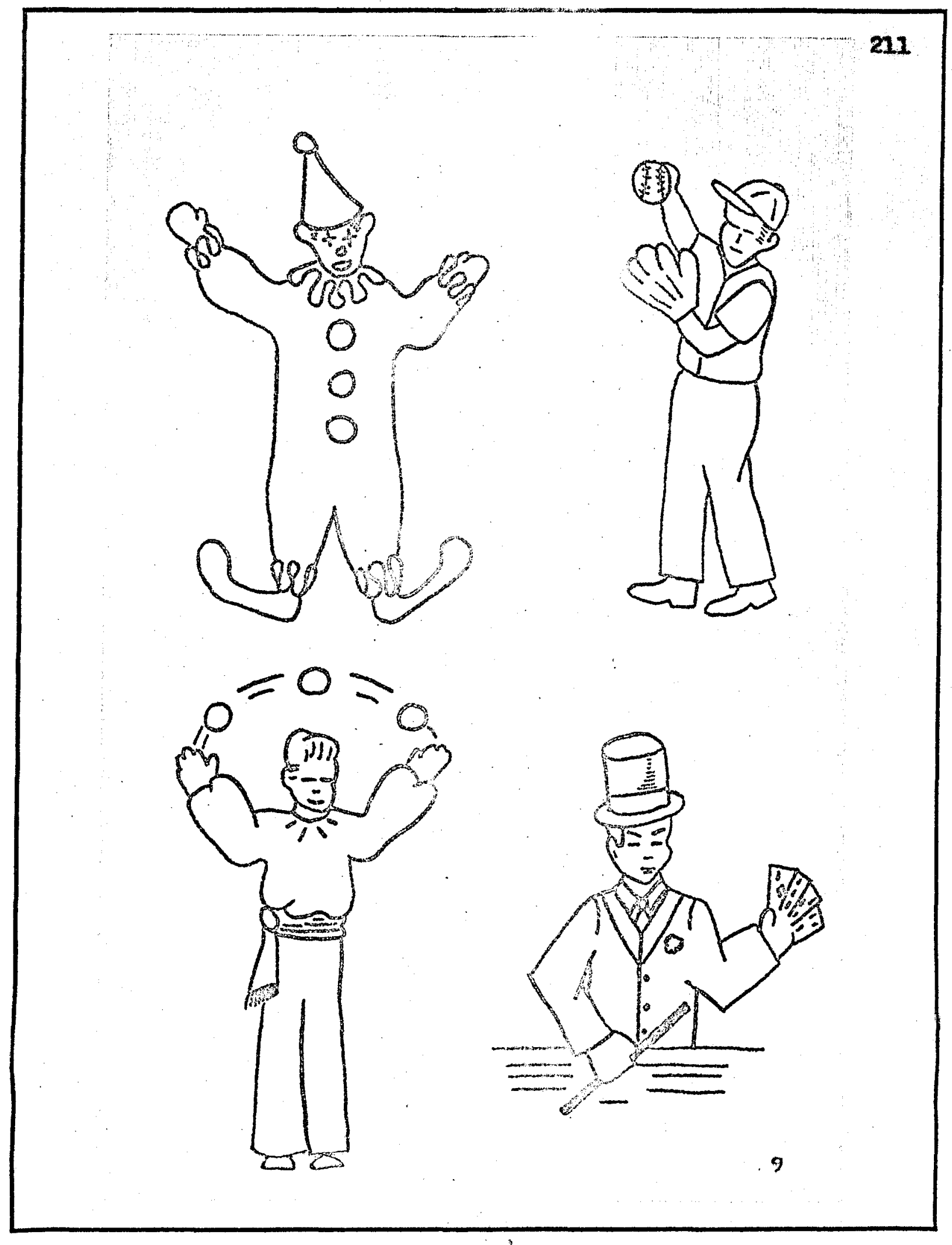




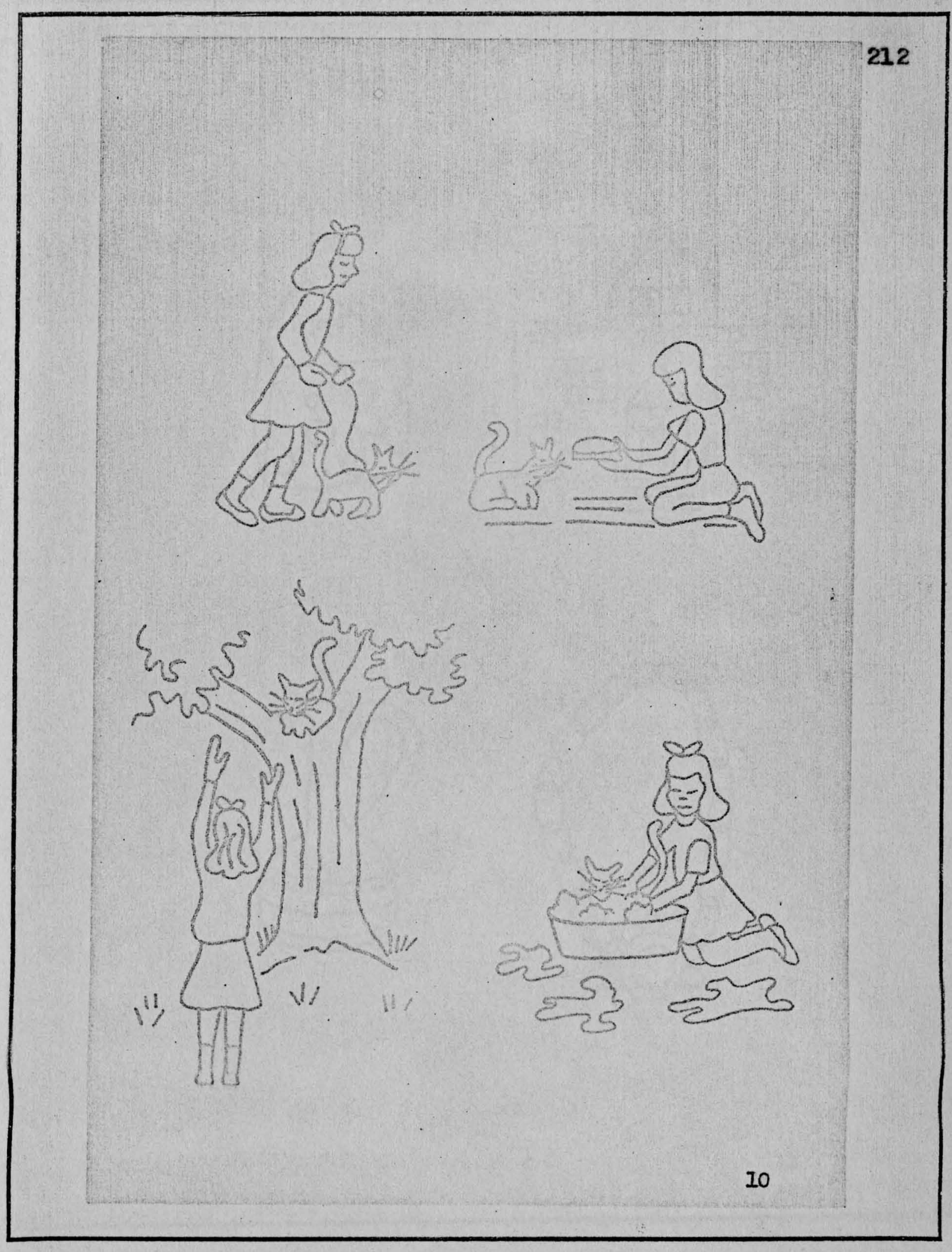




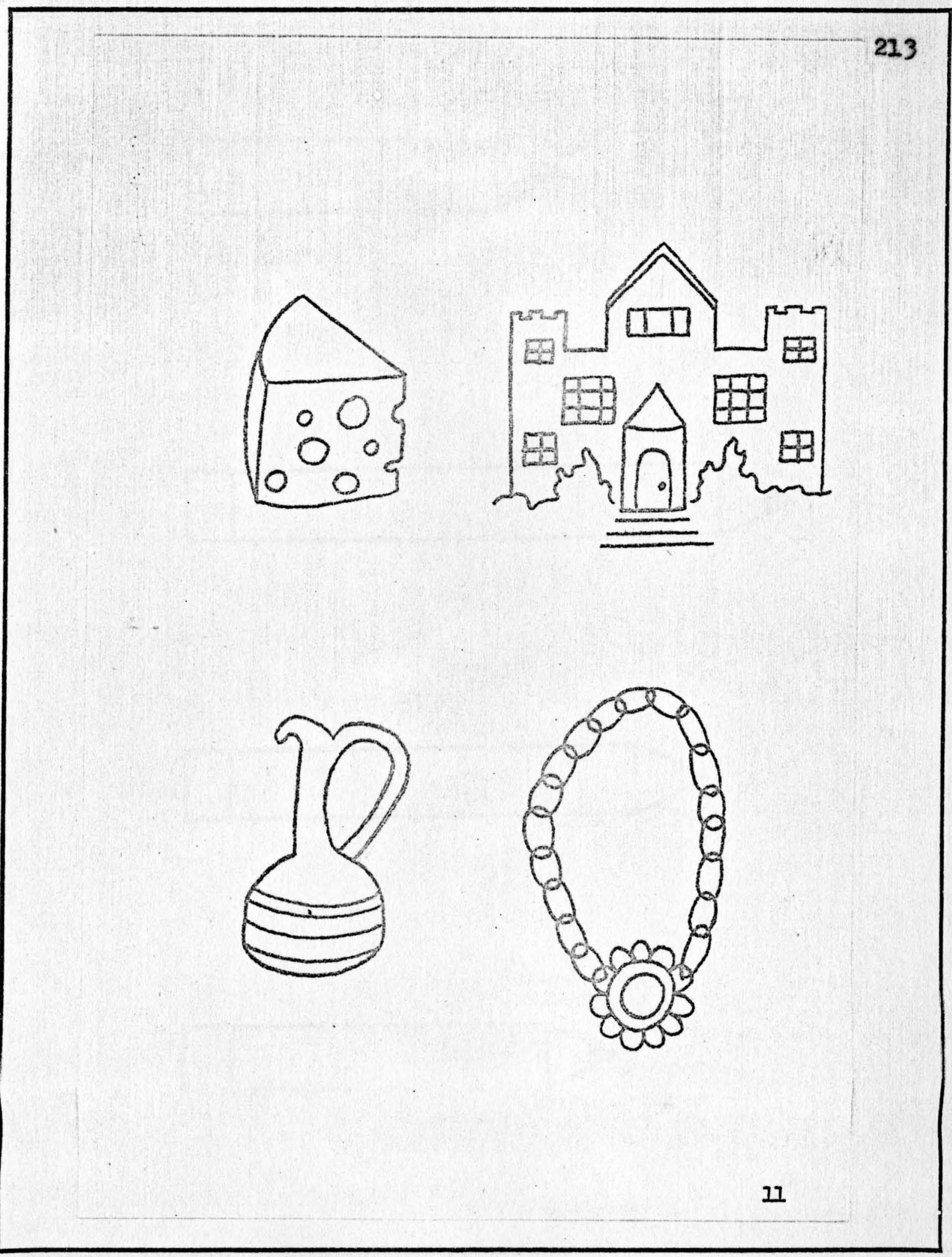




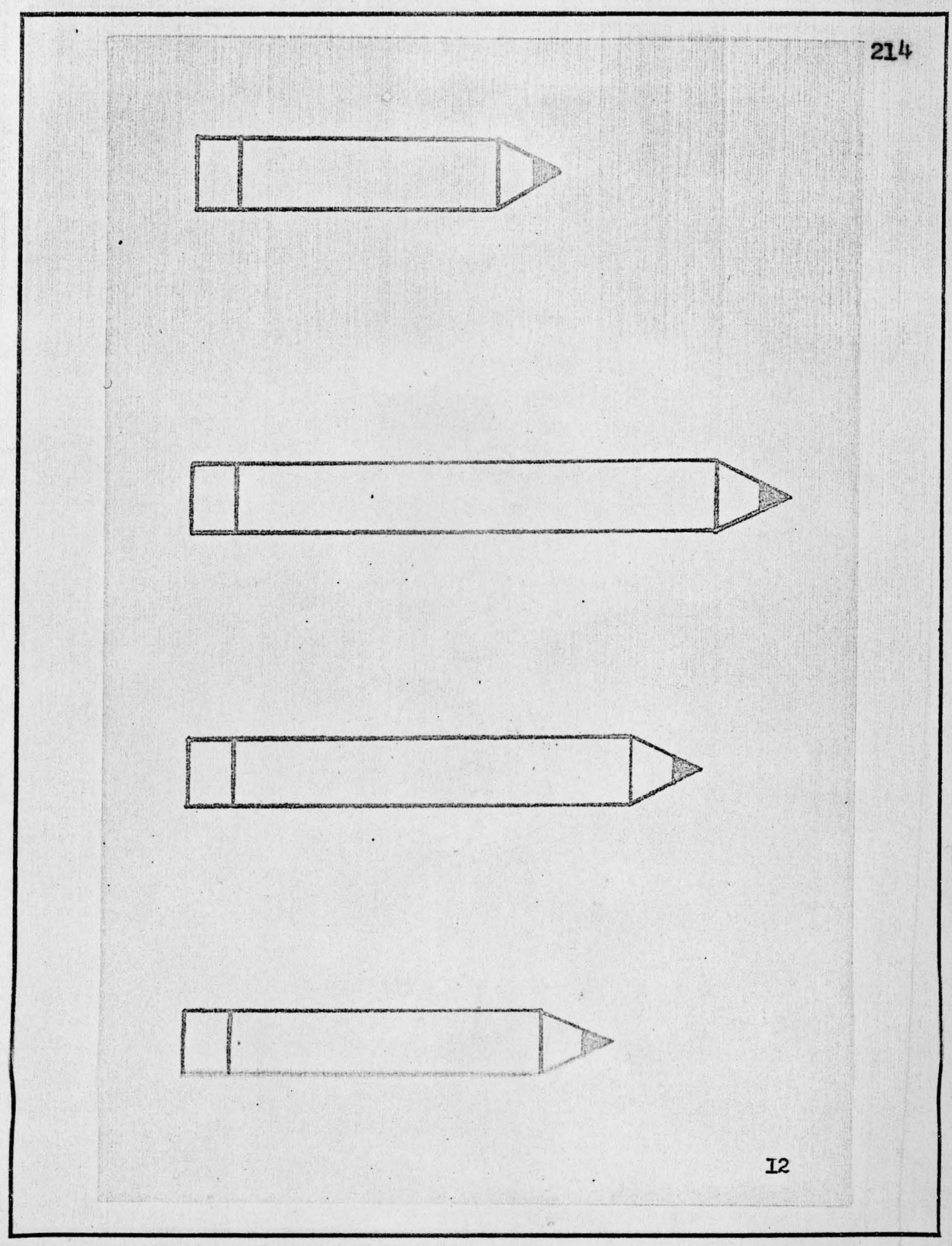




\begin{tabular}{|c|}
\hline 3 \\
5 \\
6 \\
8 \\
9 \\
71 \\
\hline
\end{tabular}




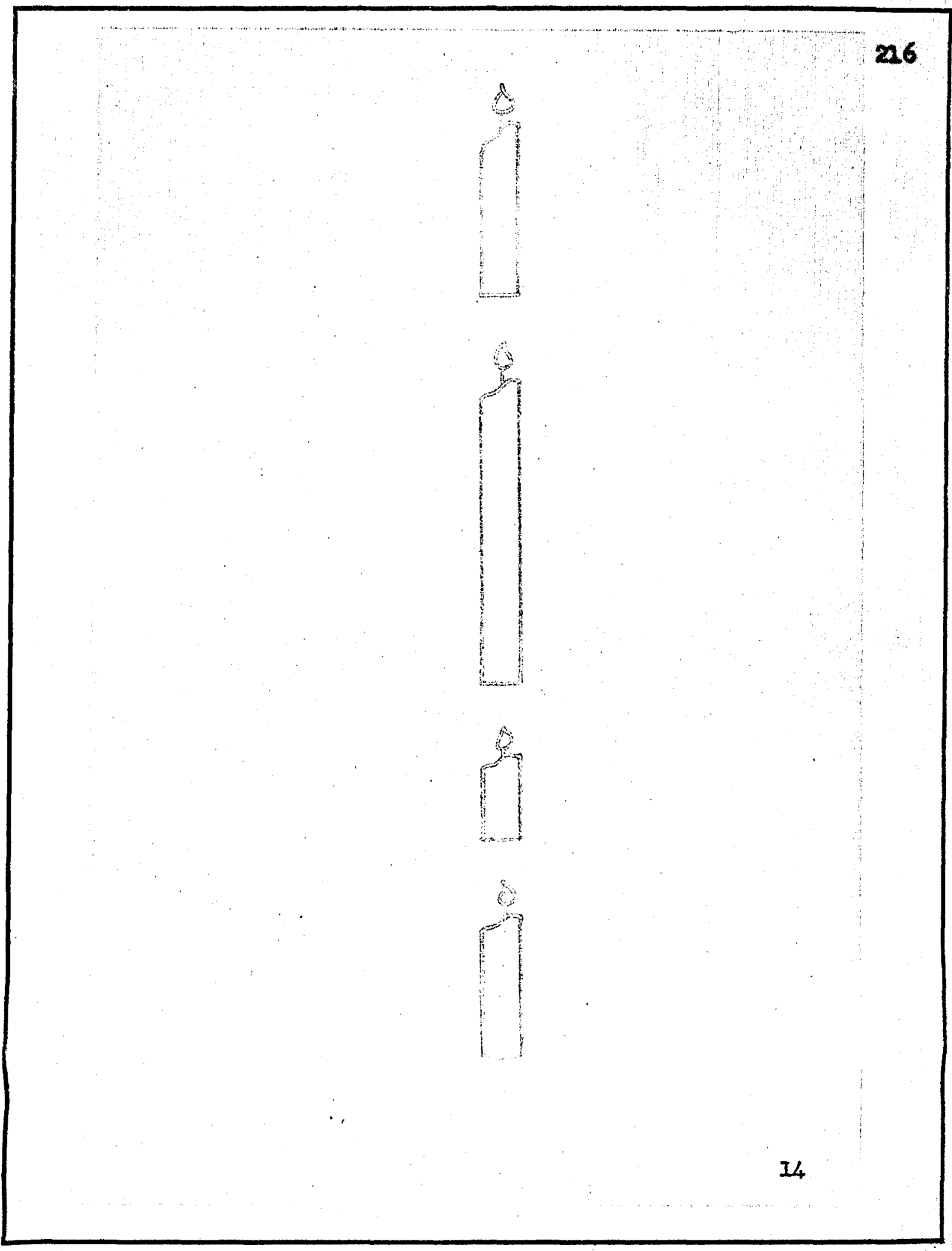




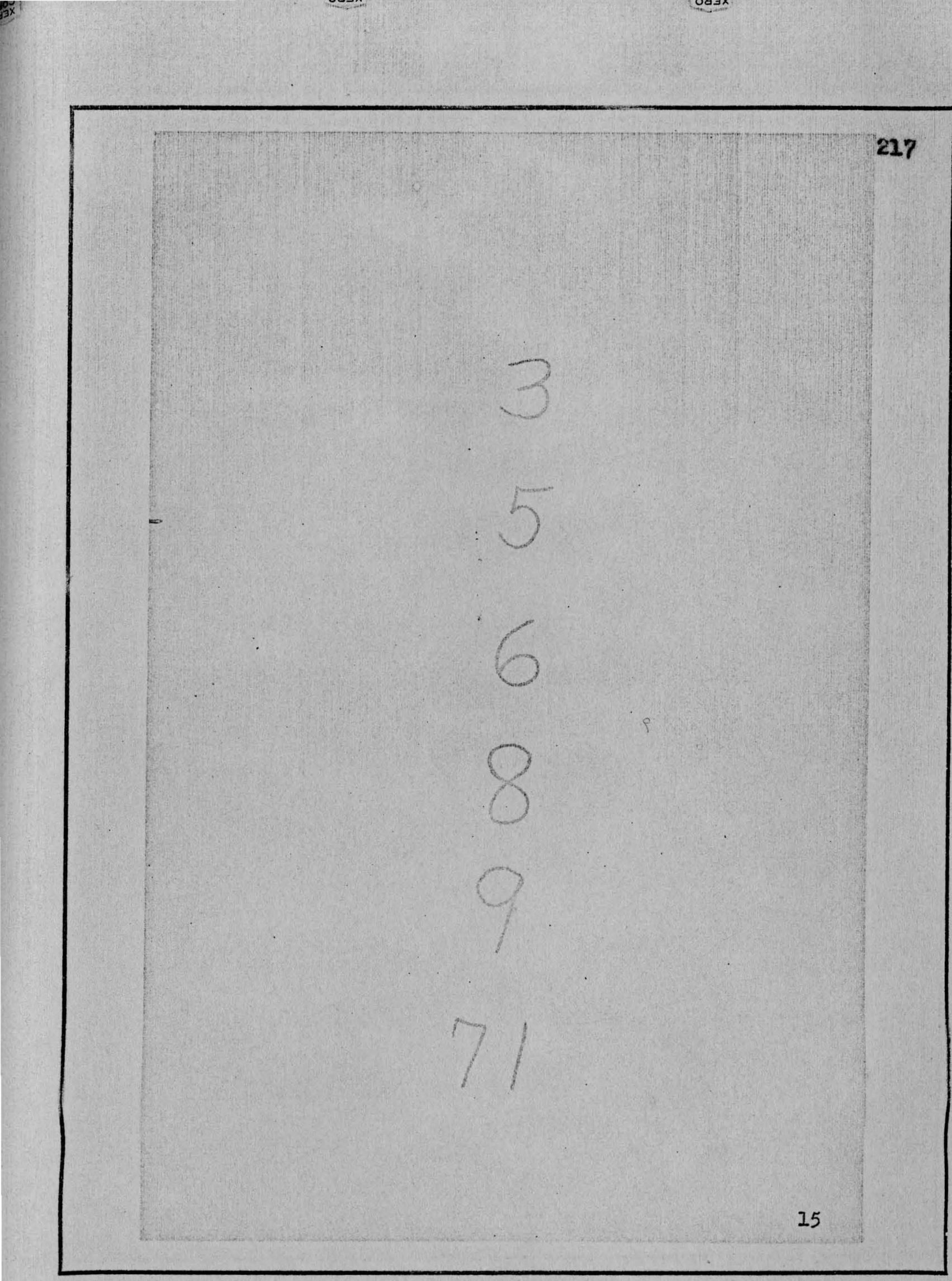






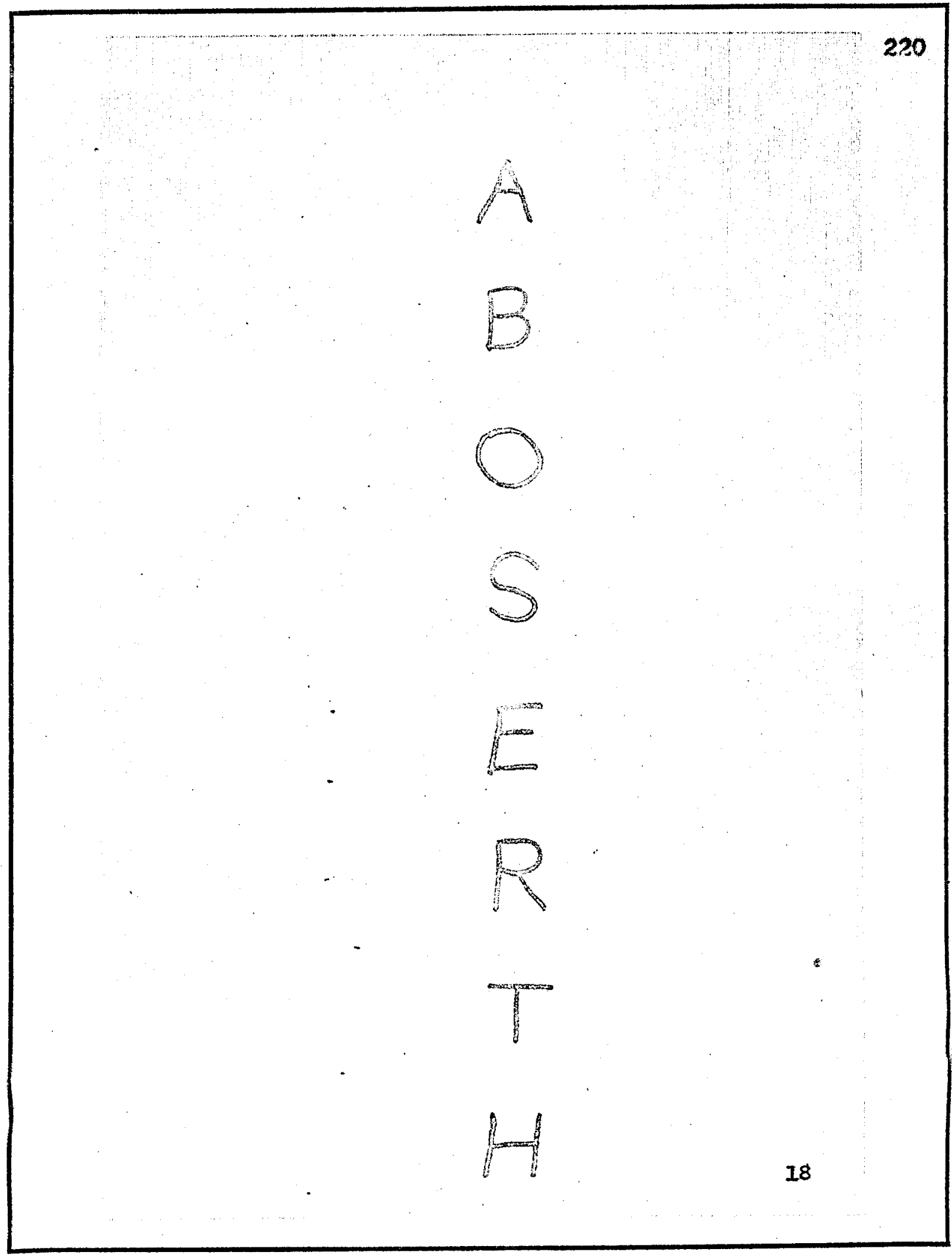




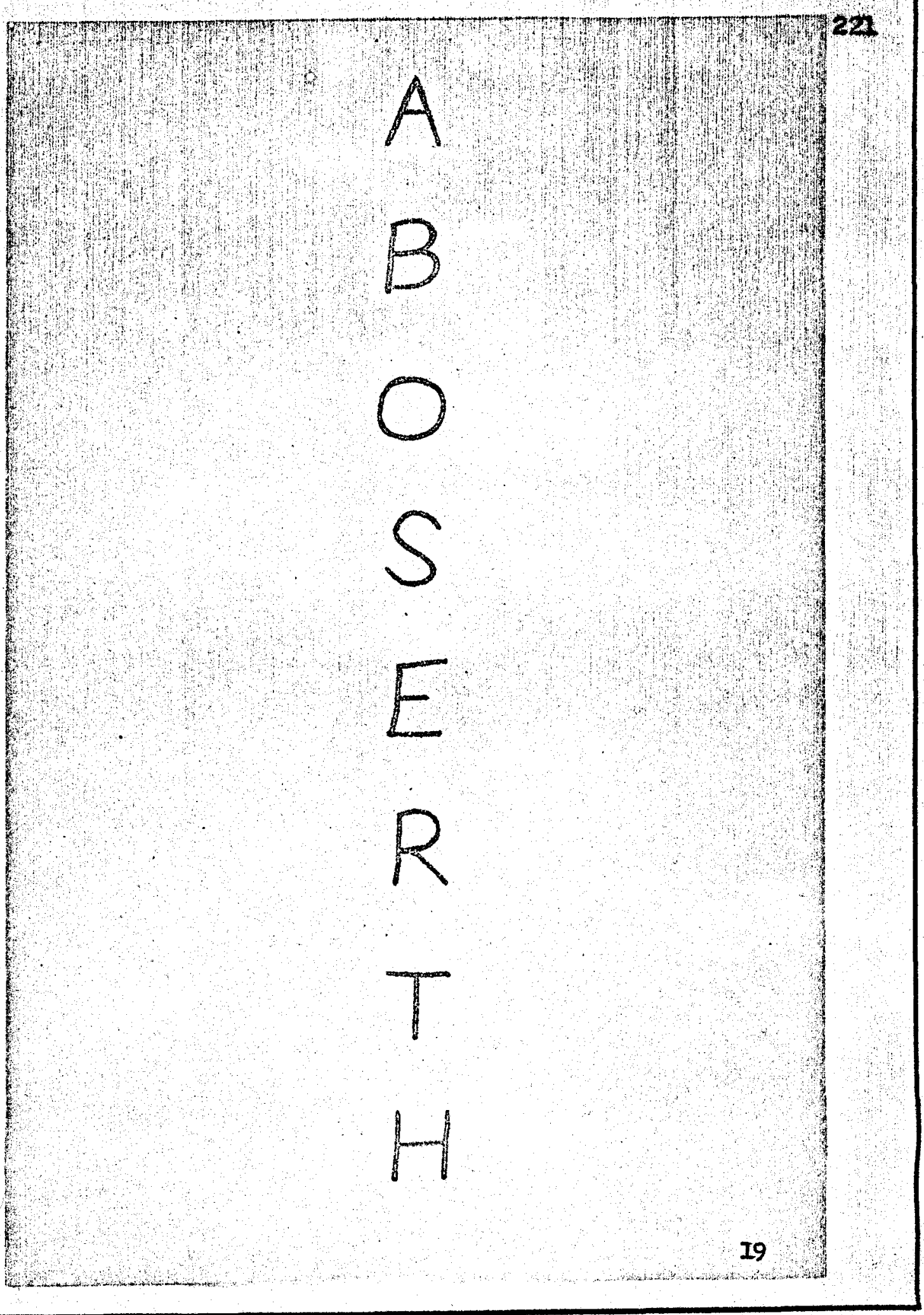




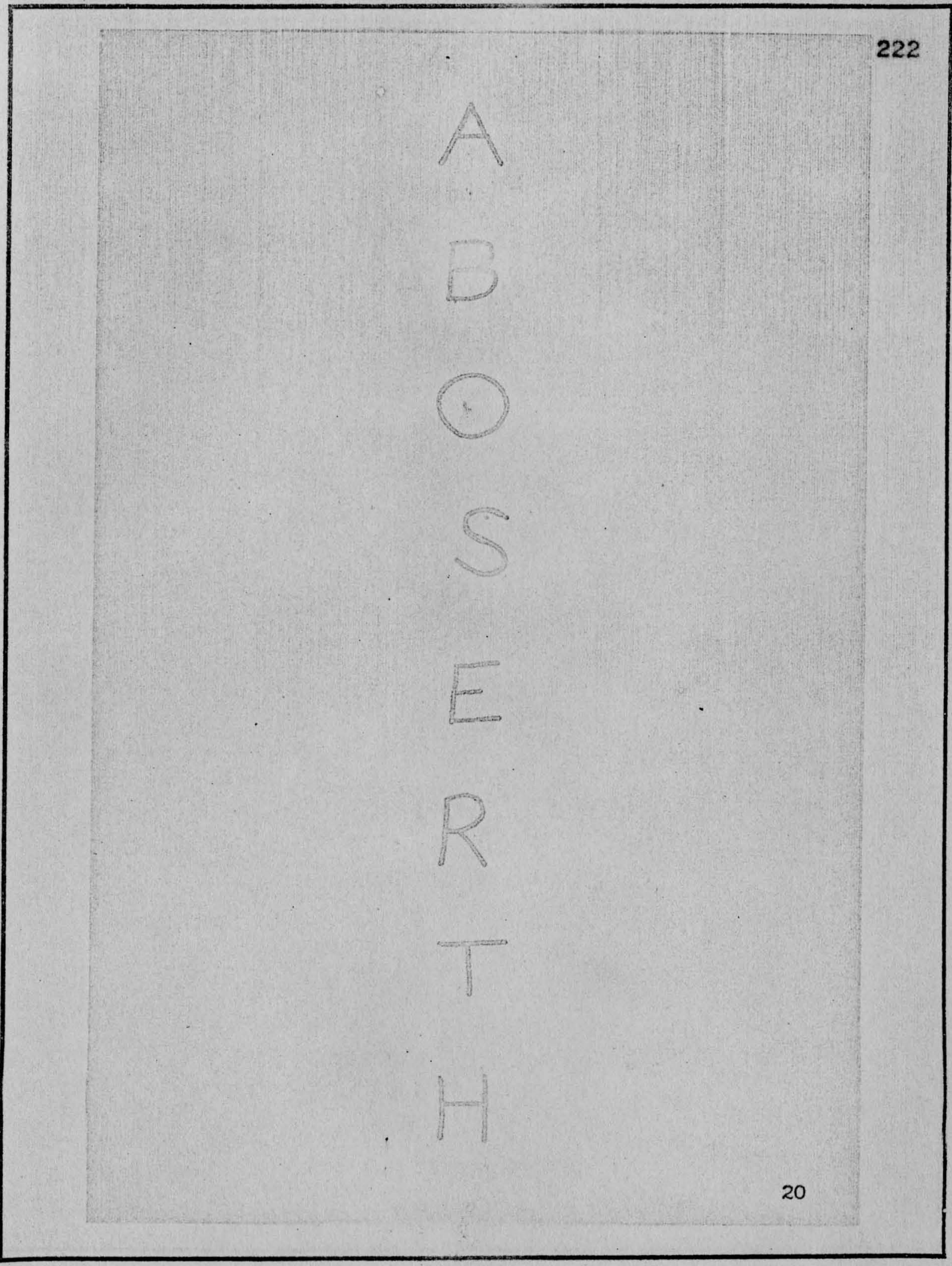




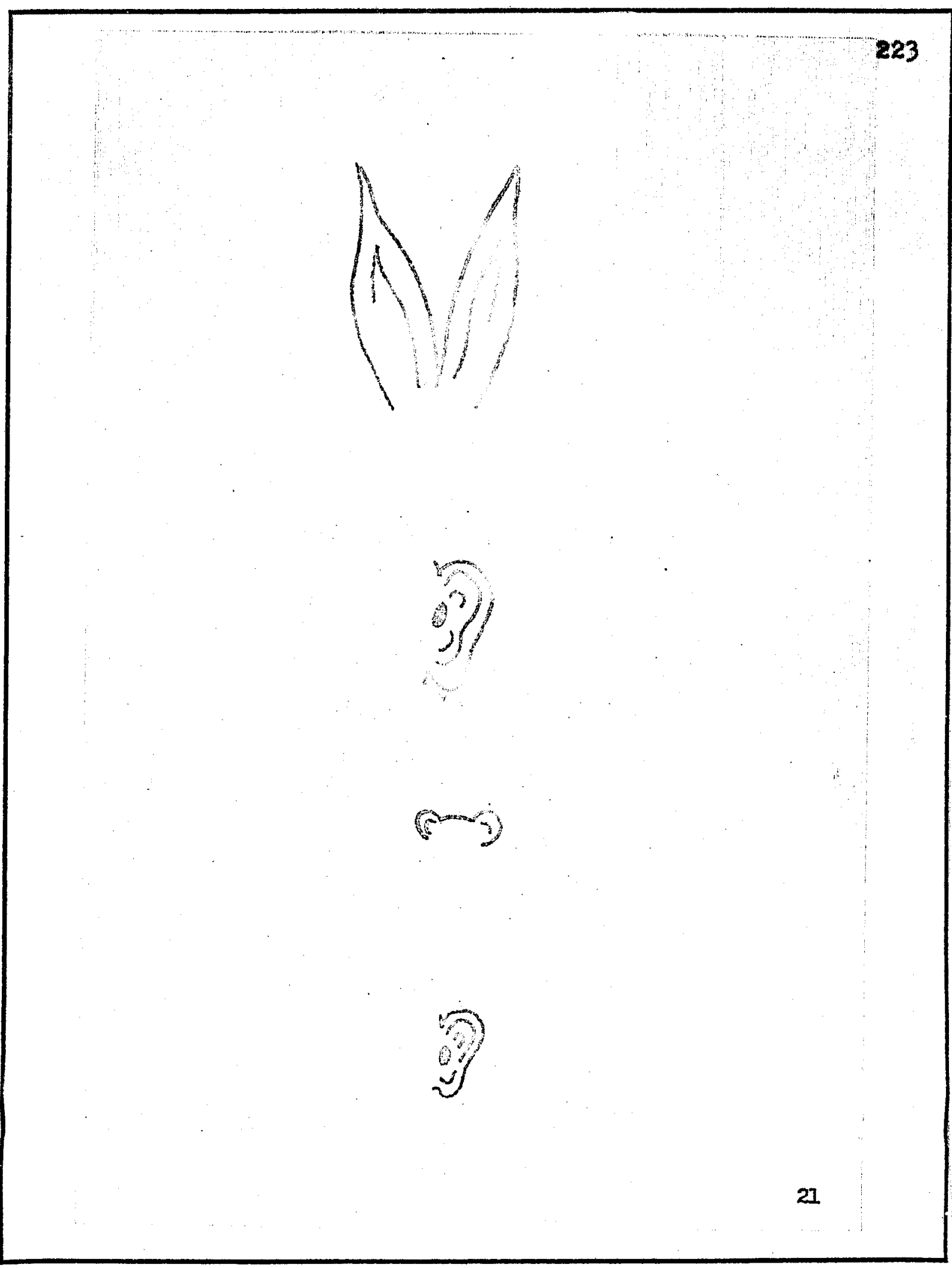




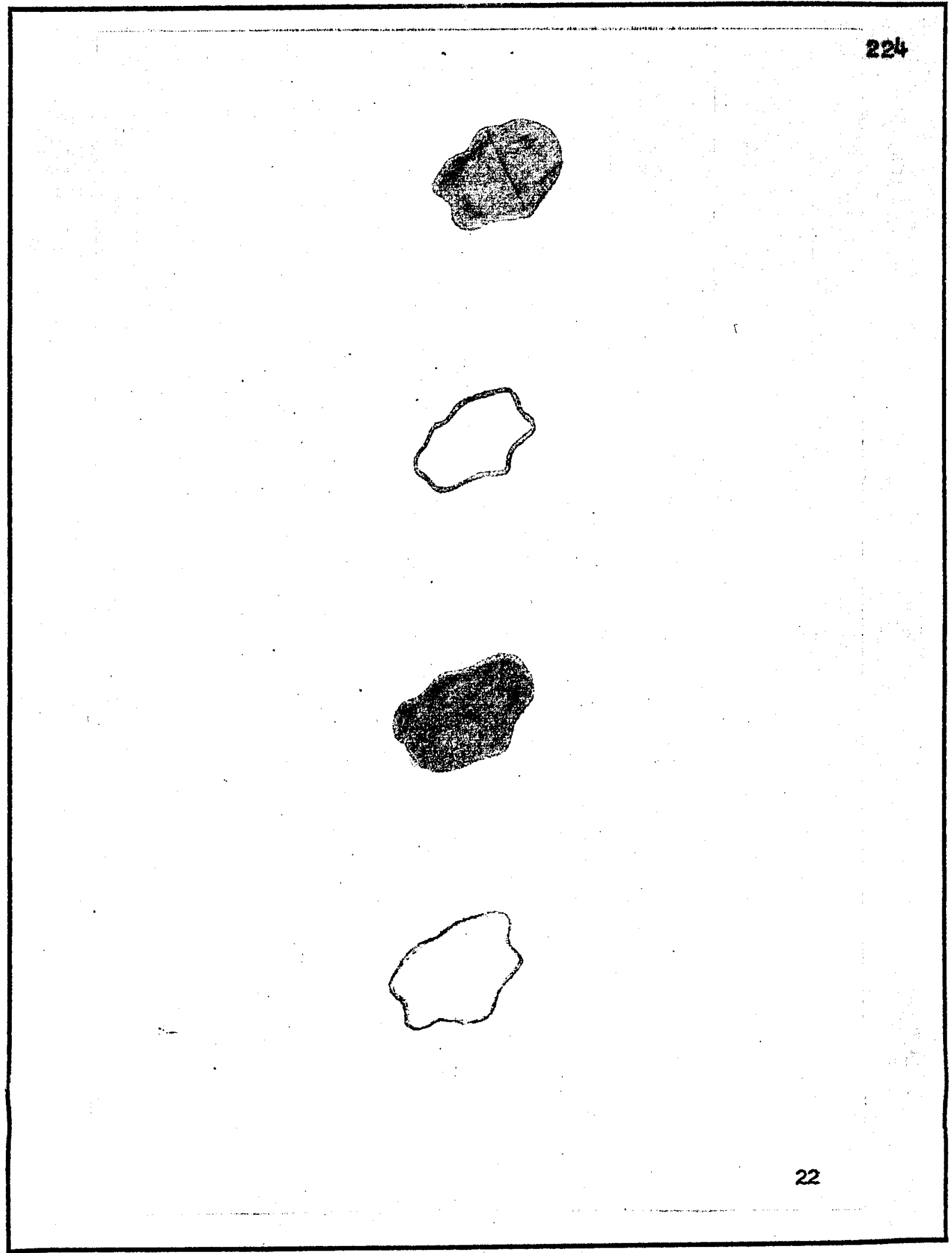




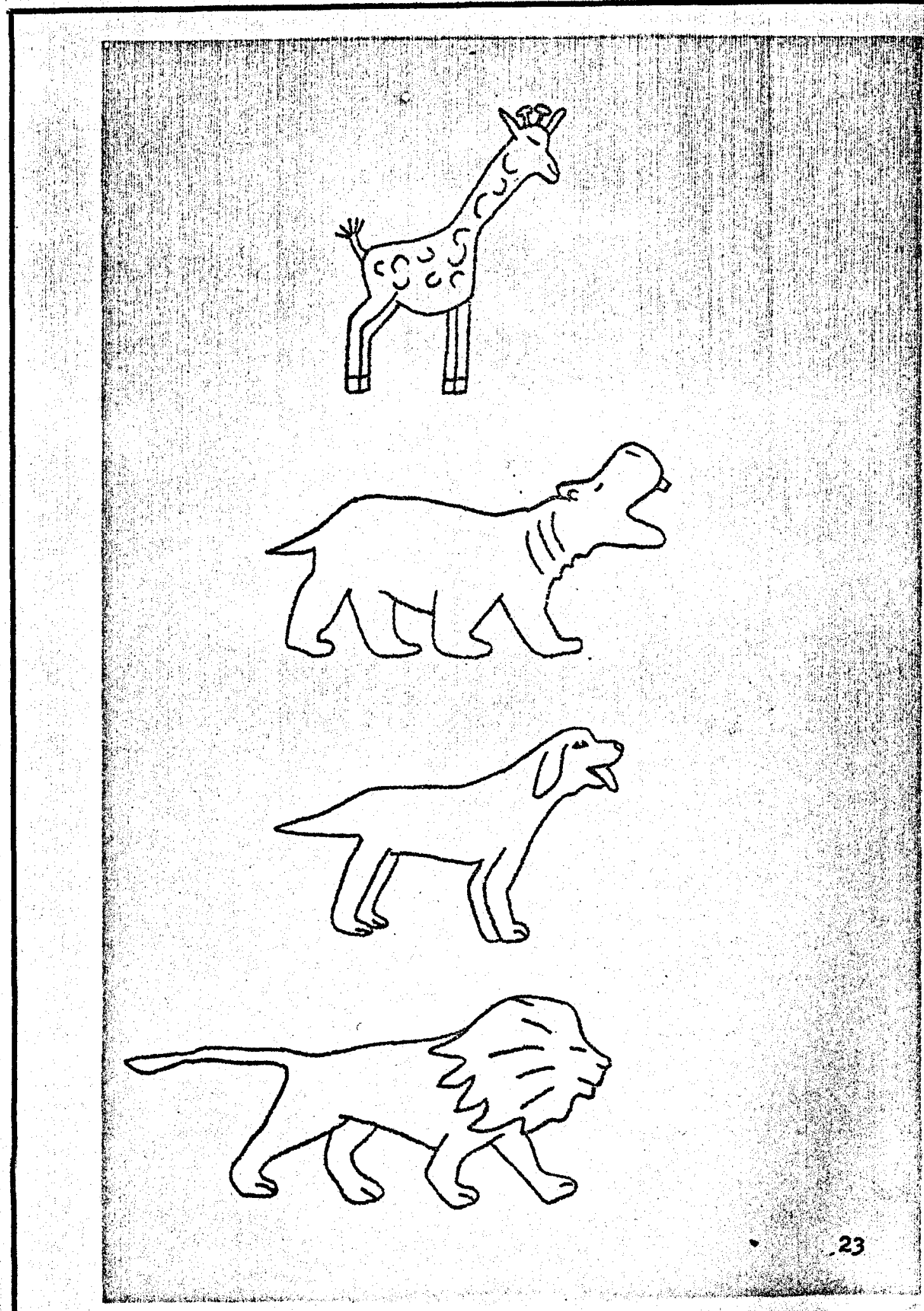




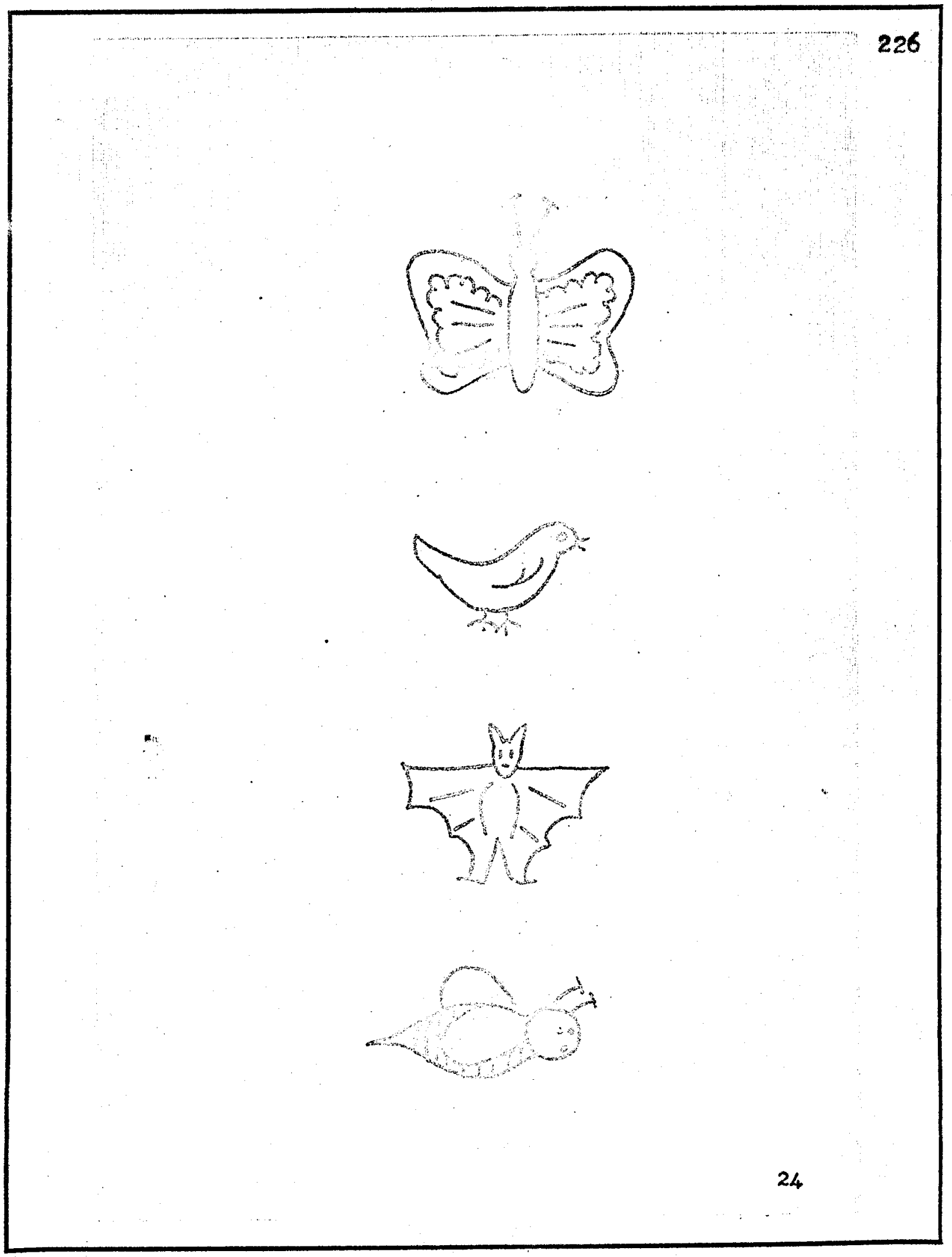




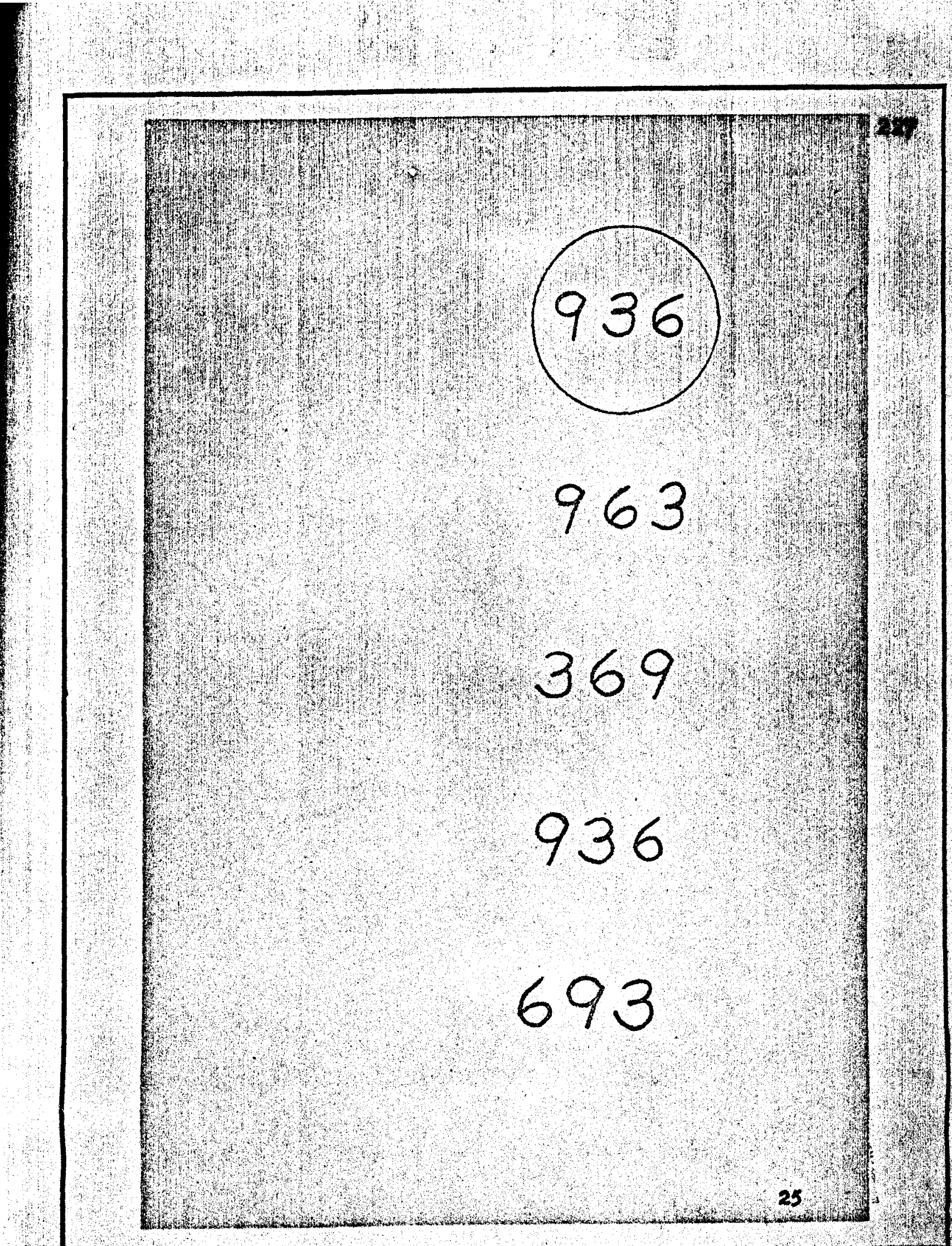




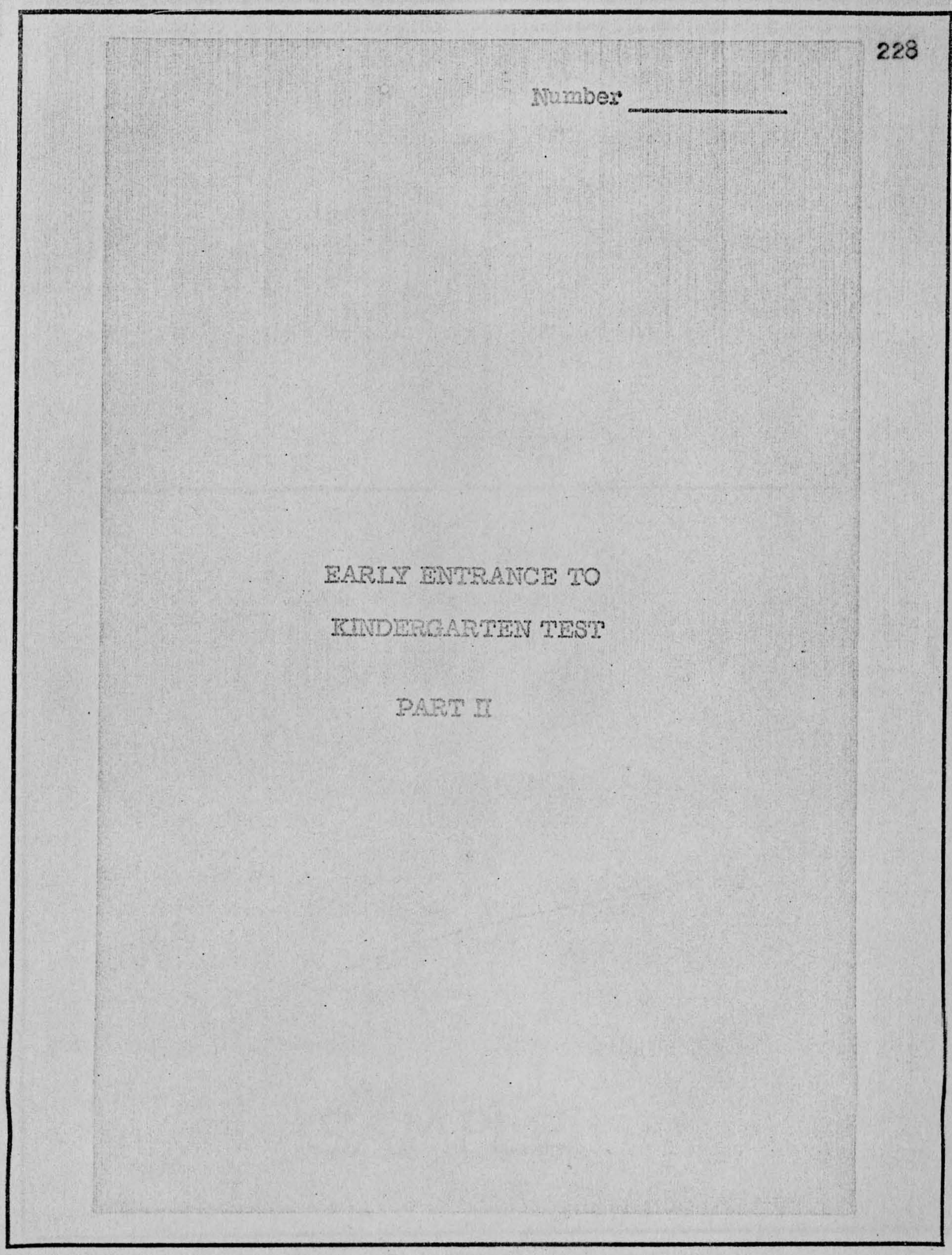




$$
\frac{\square}{I}
$$




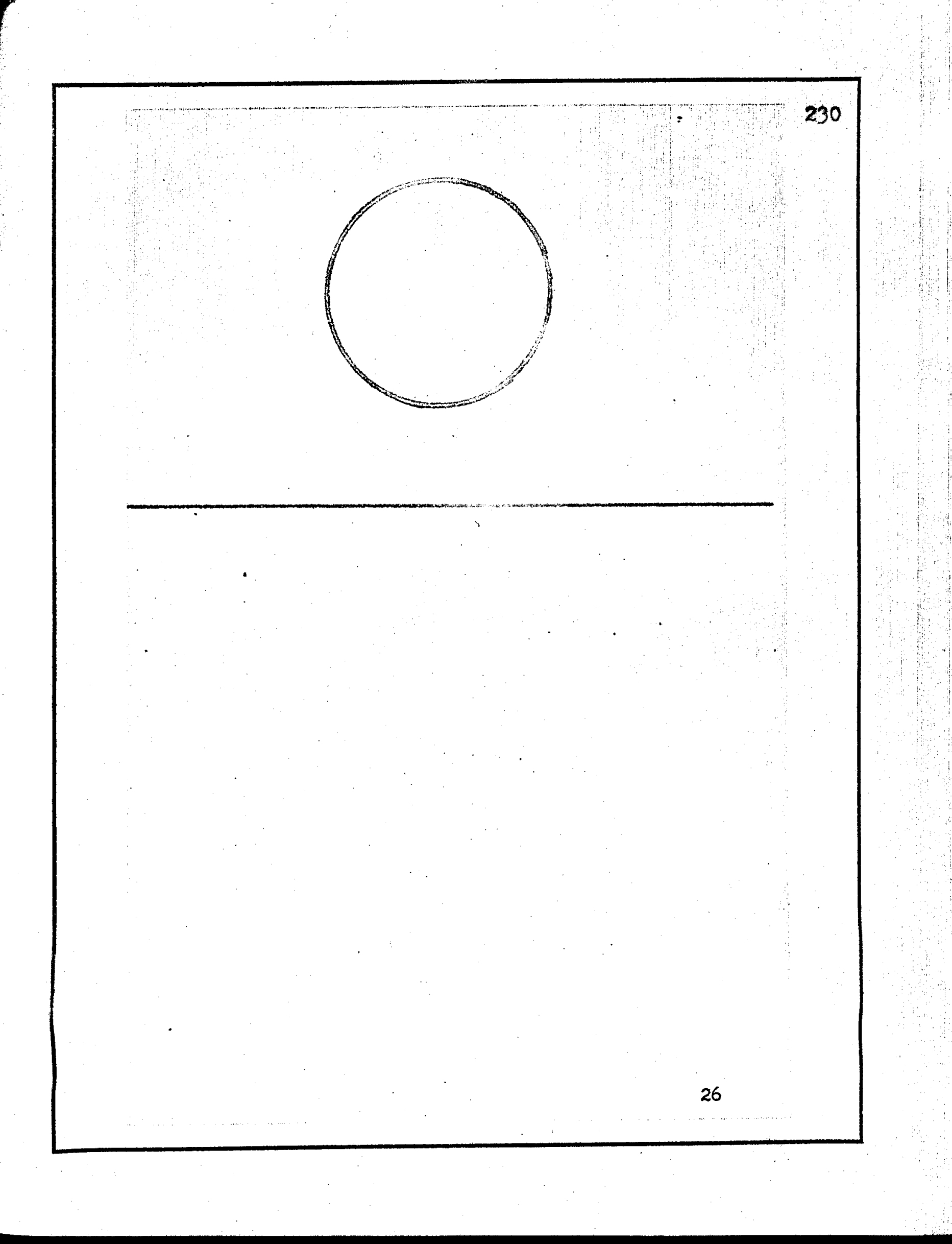




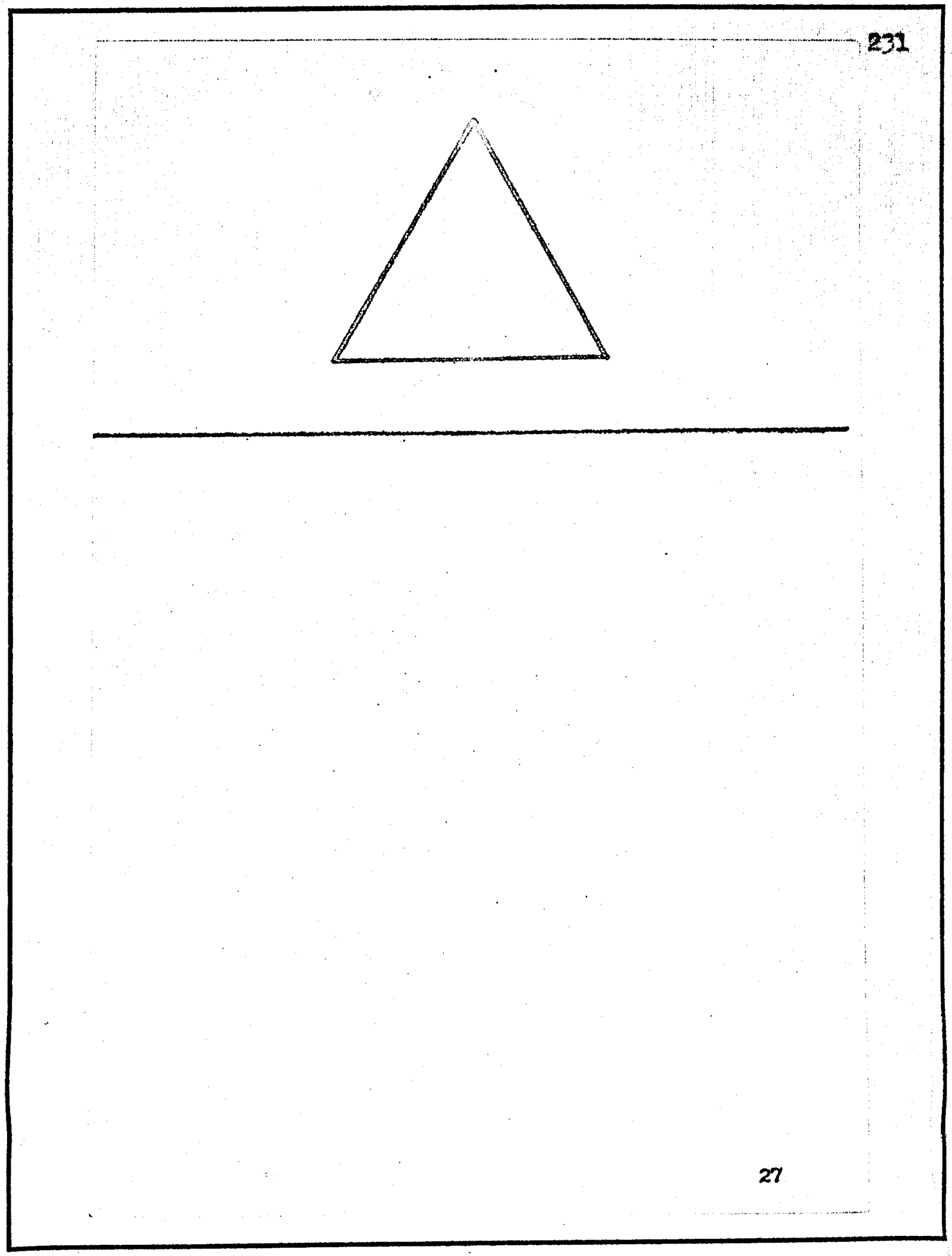




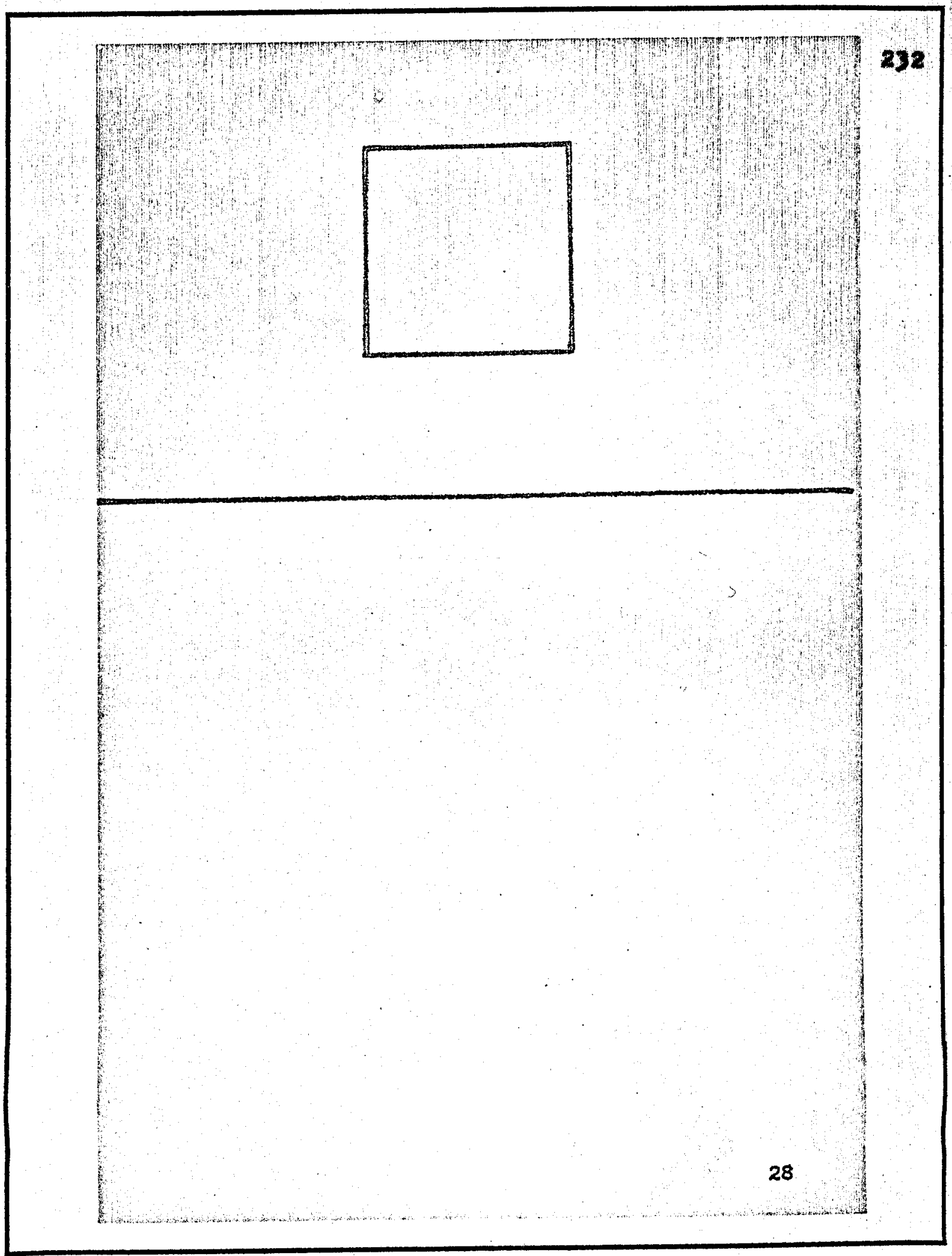




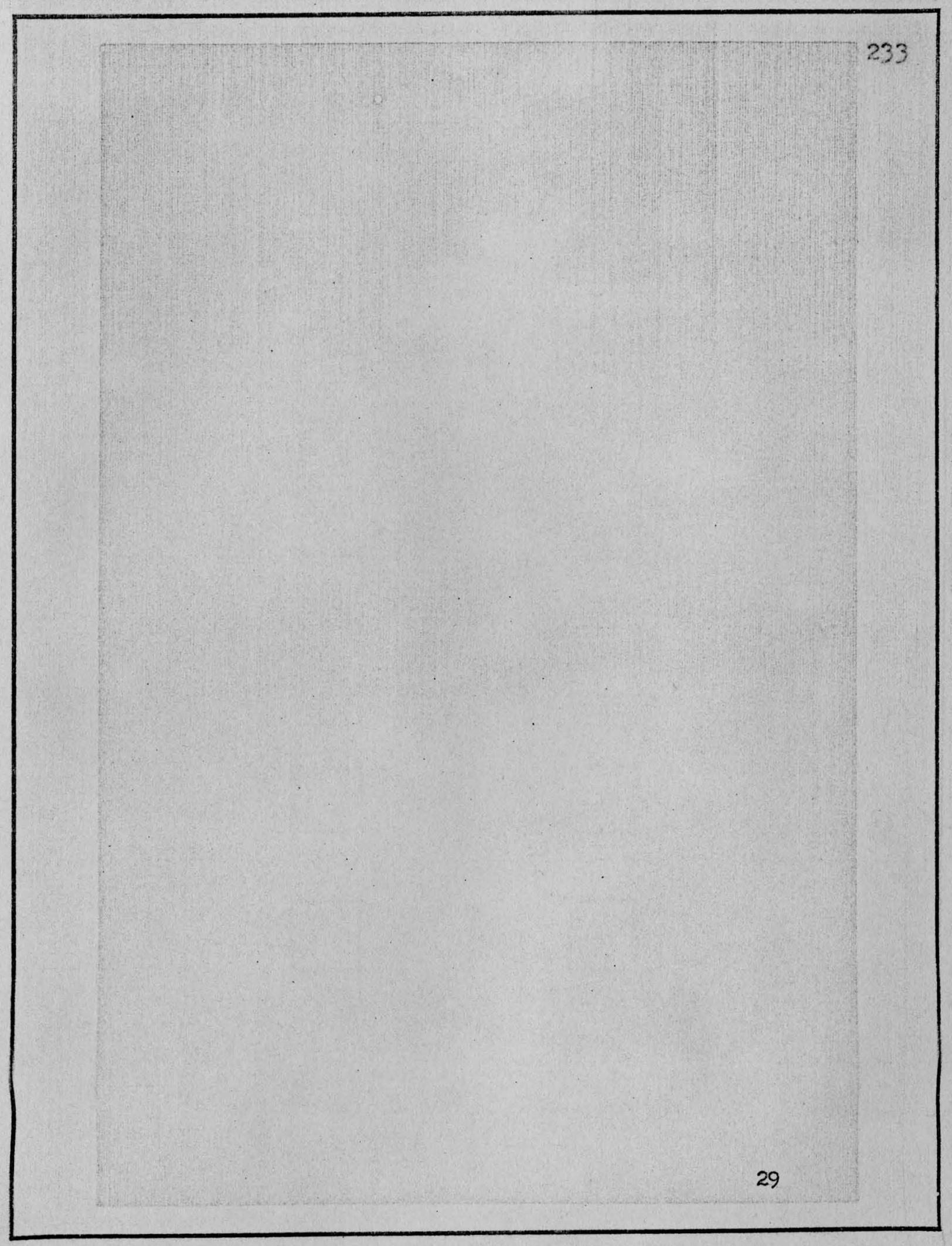




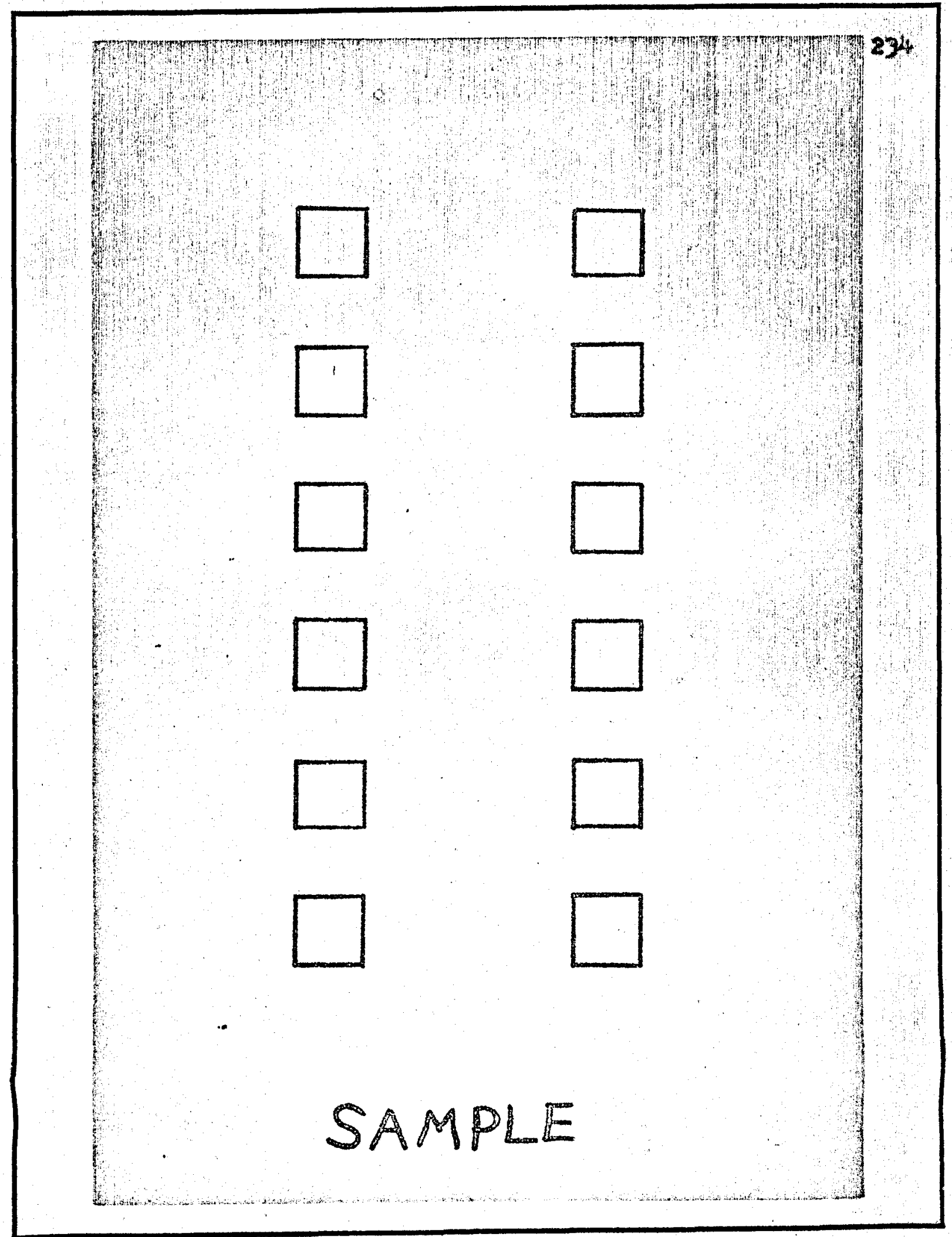




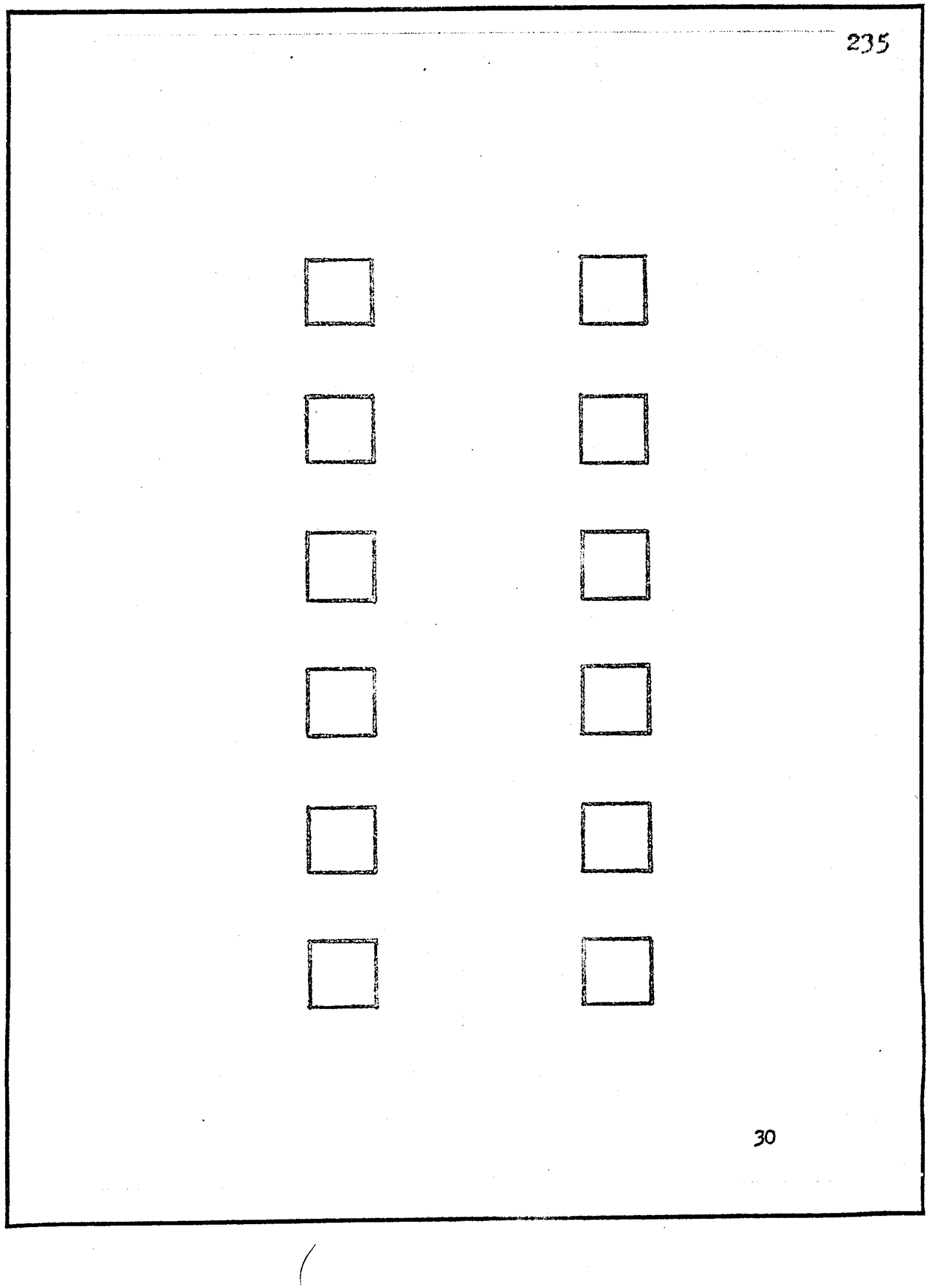




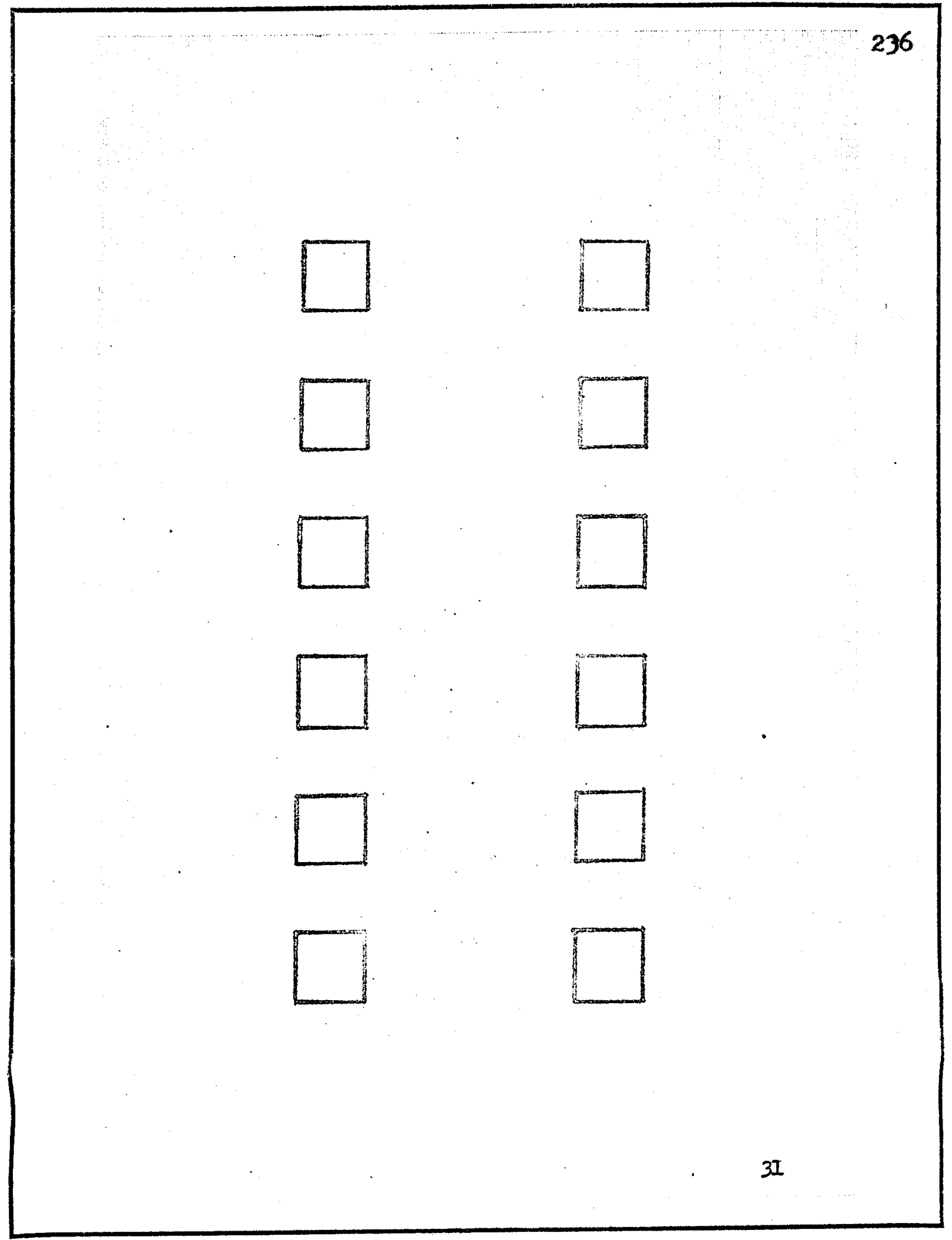




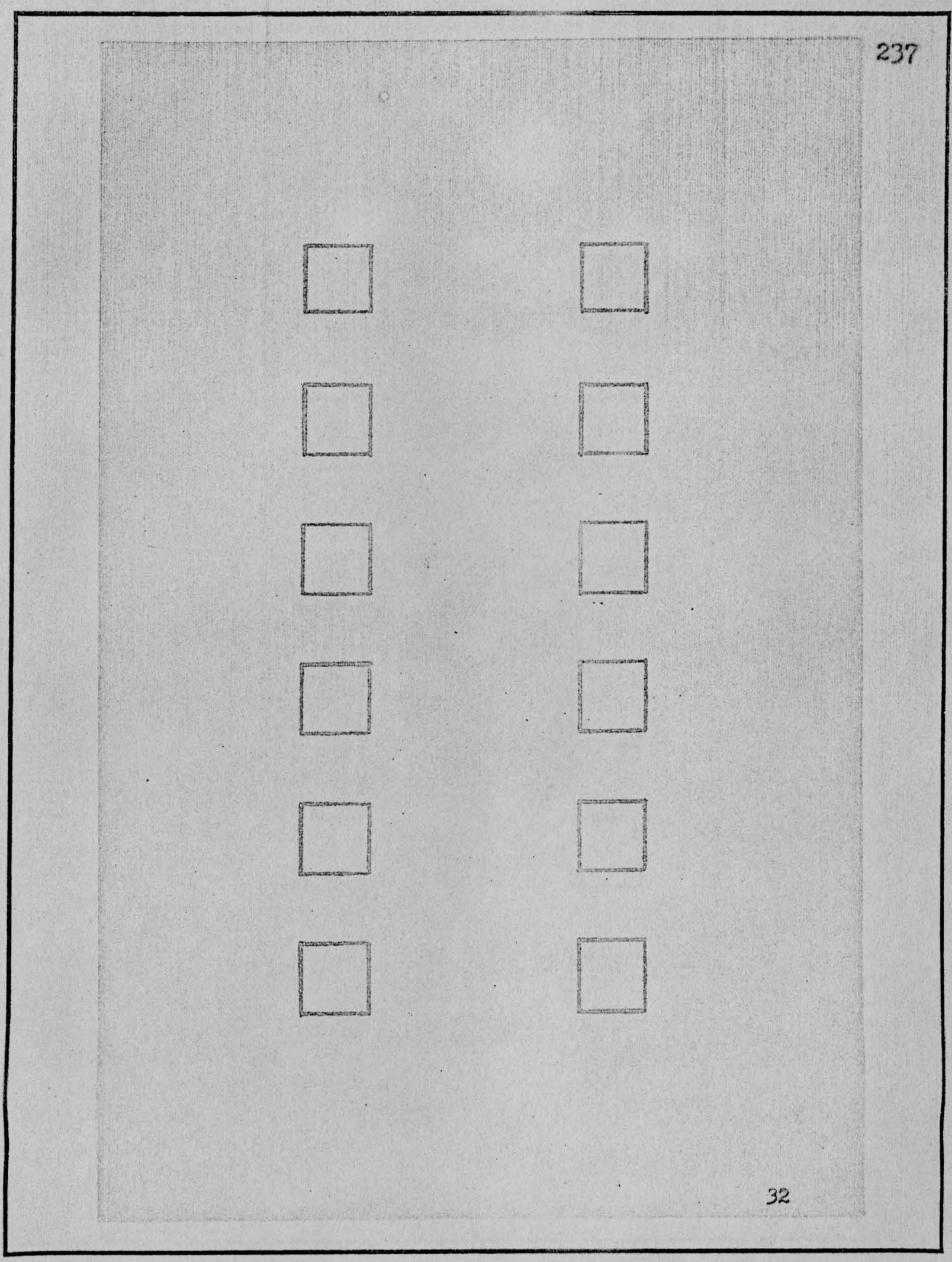




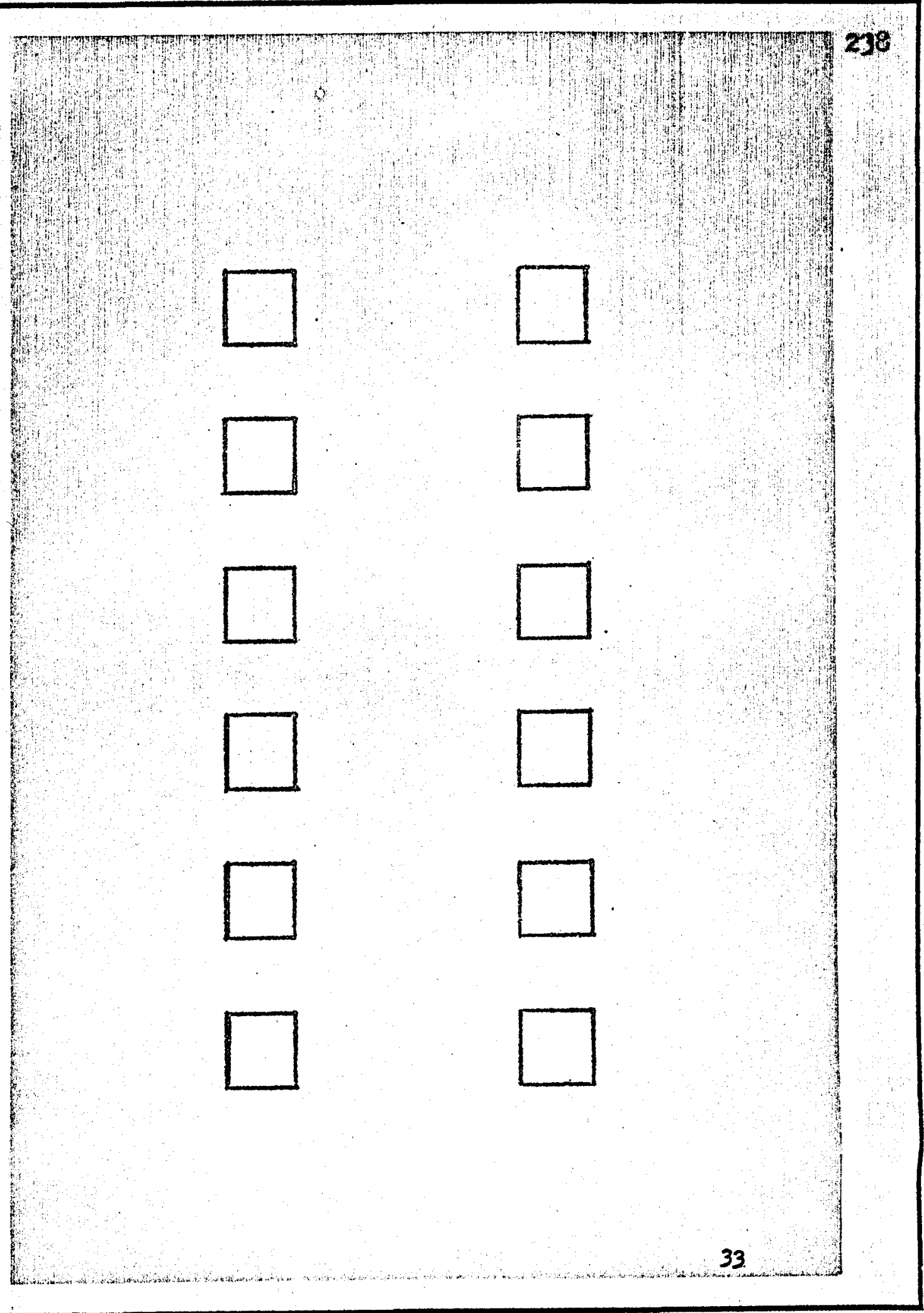




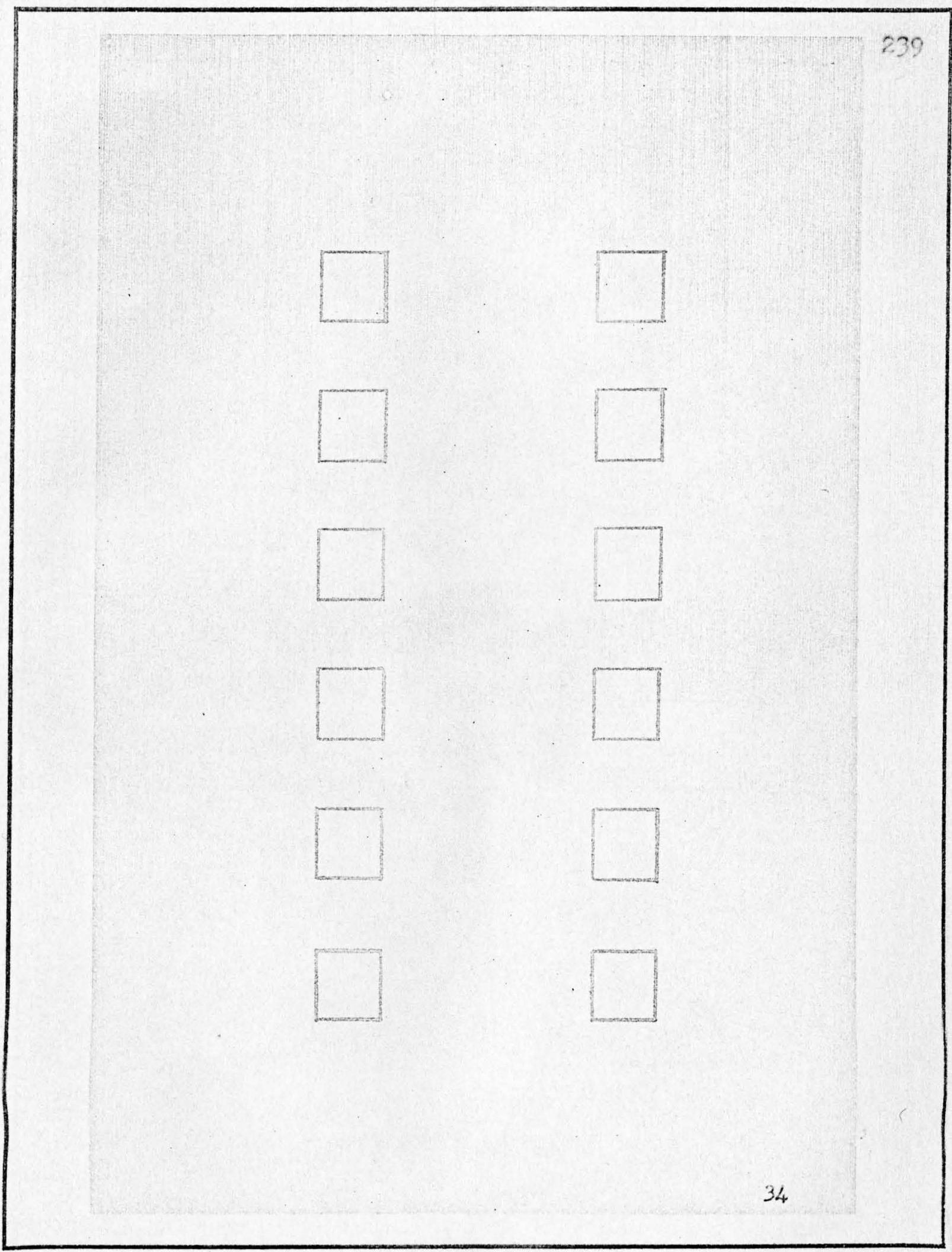




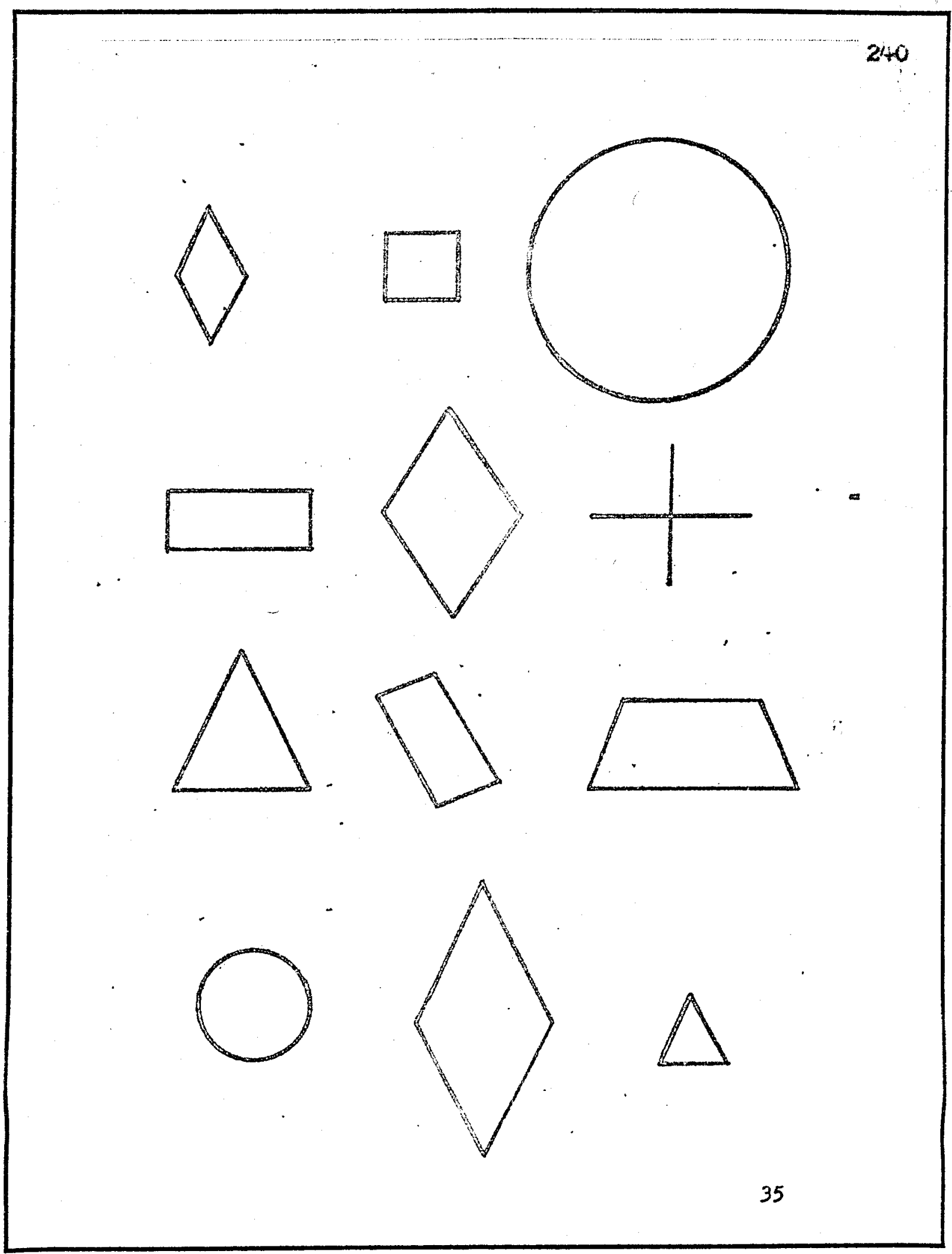




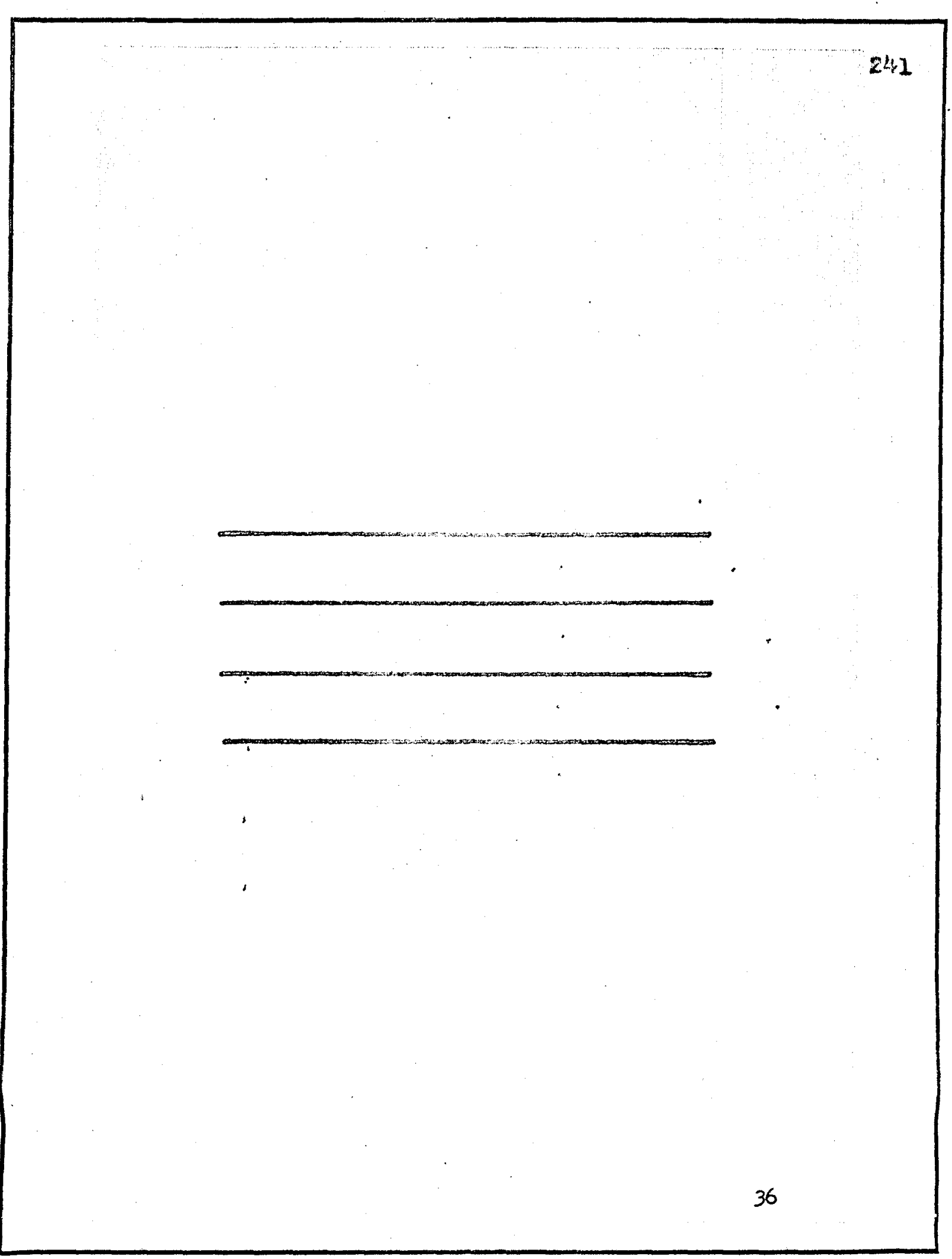




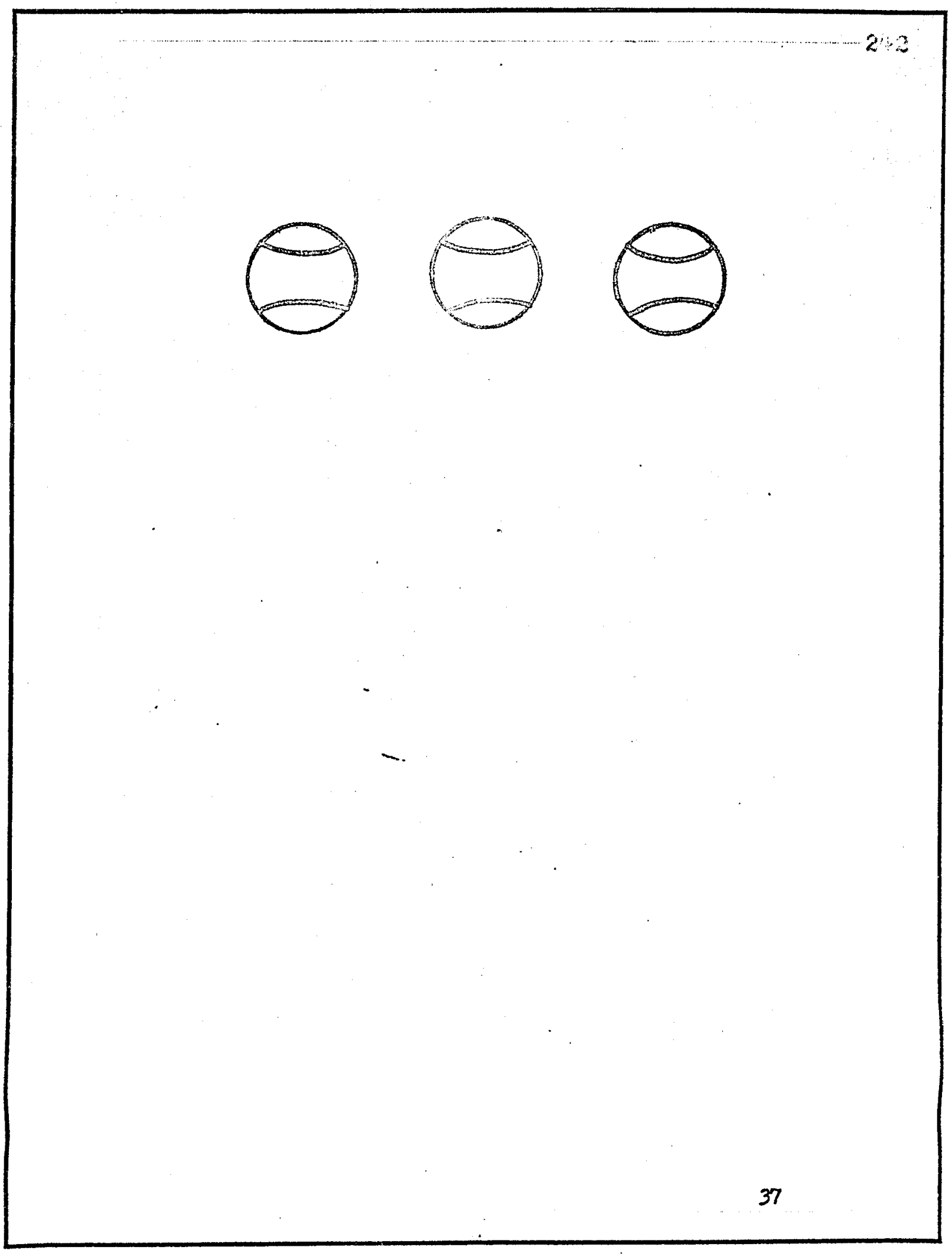




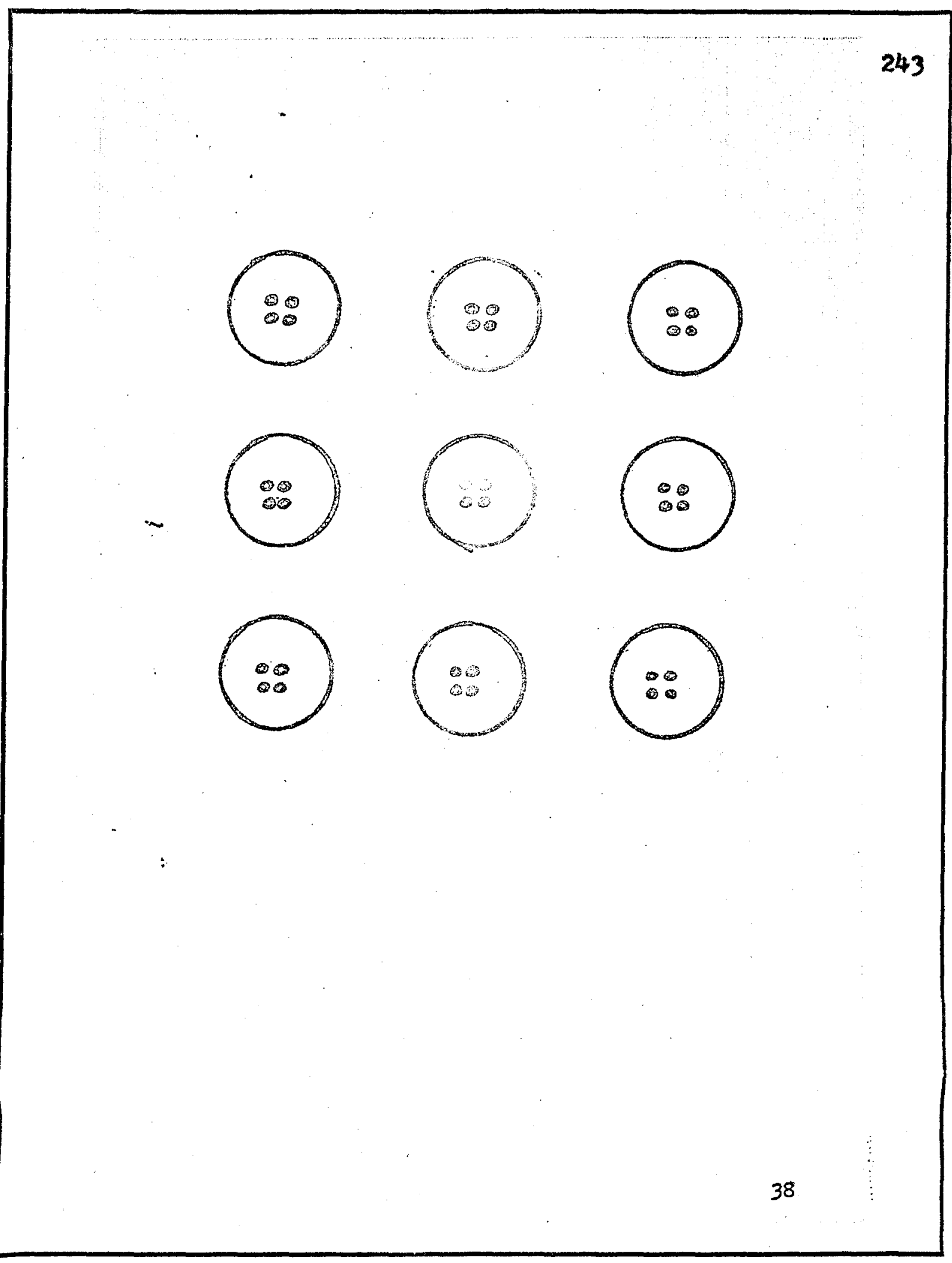




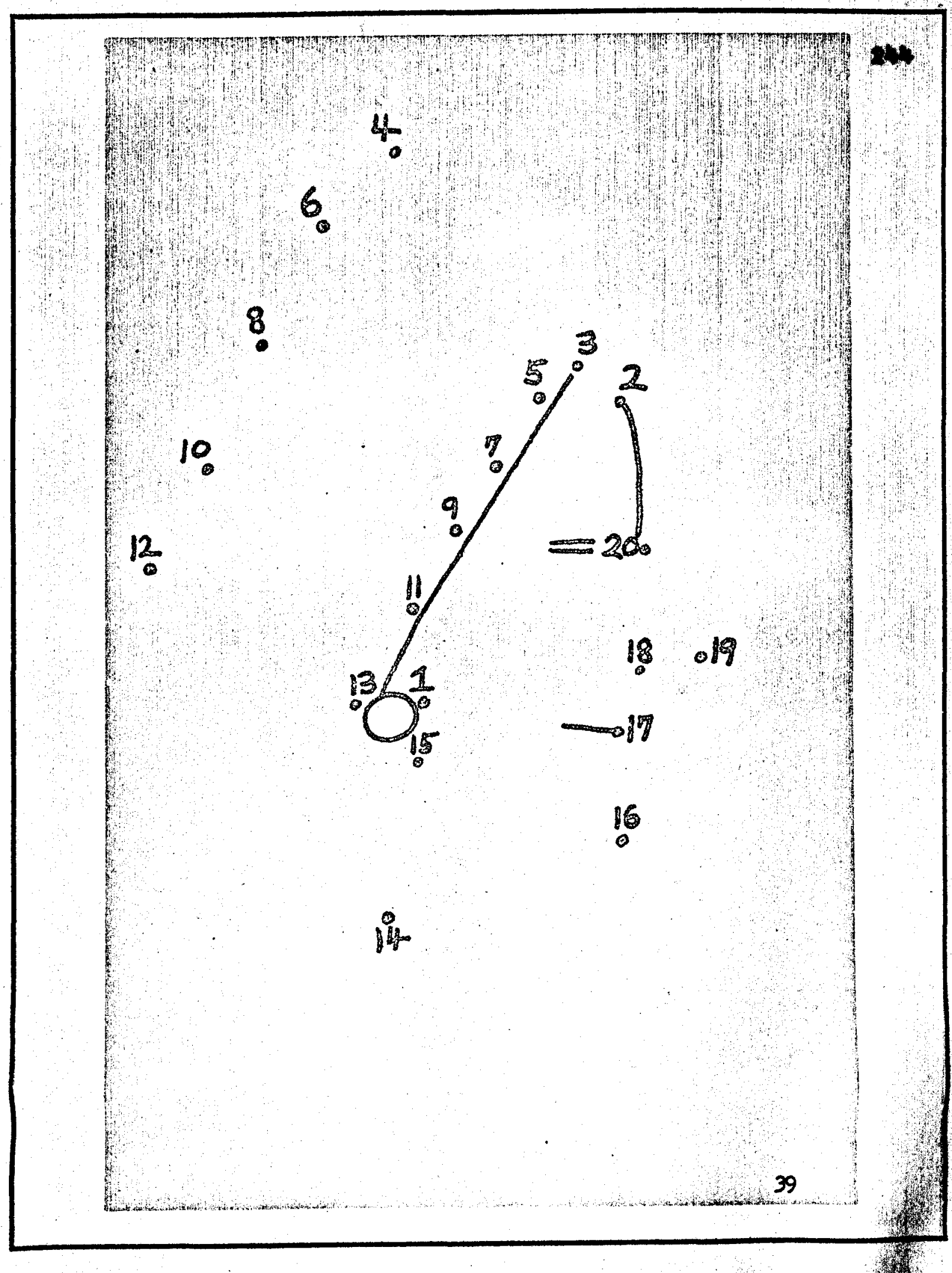




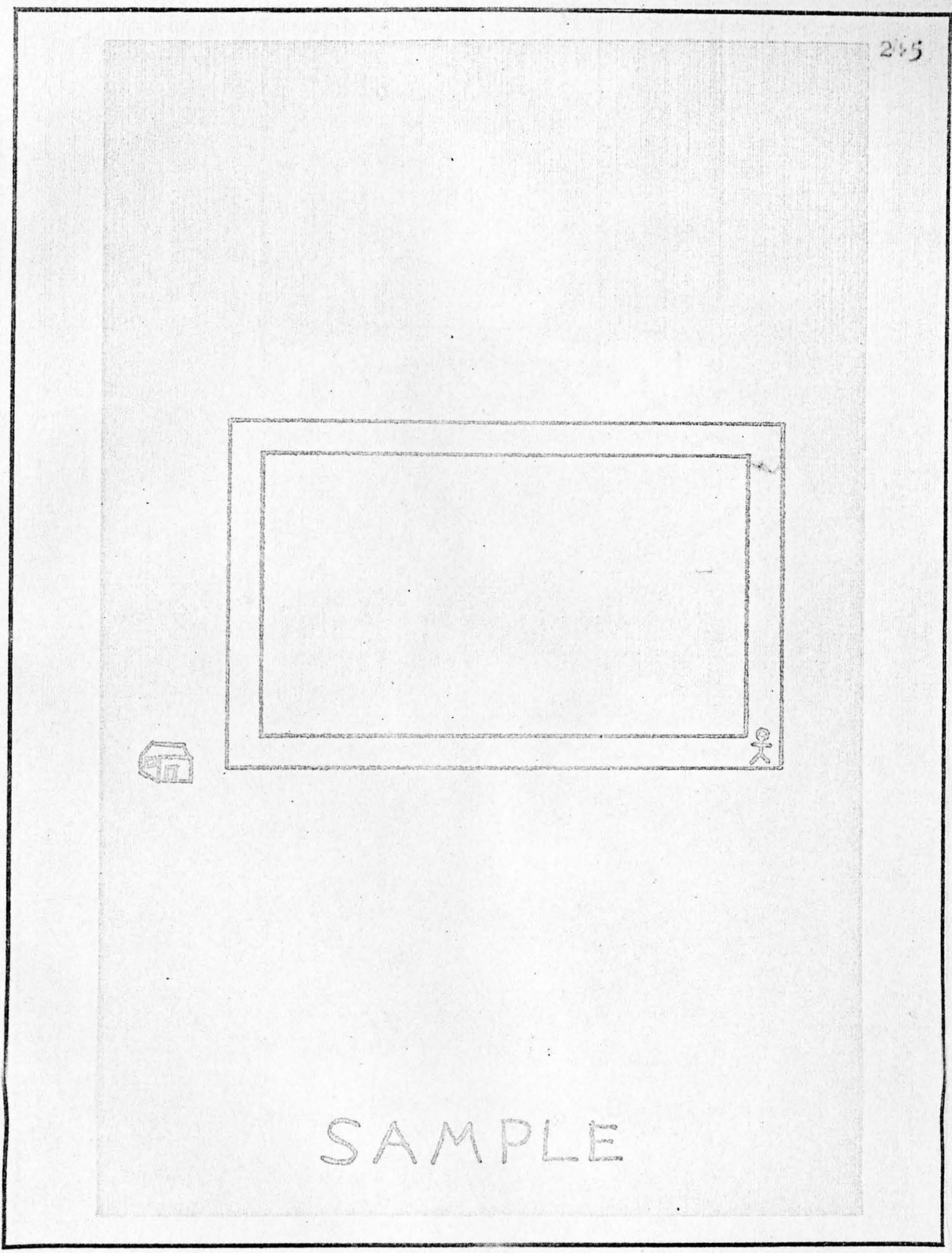




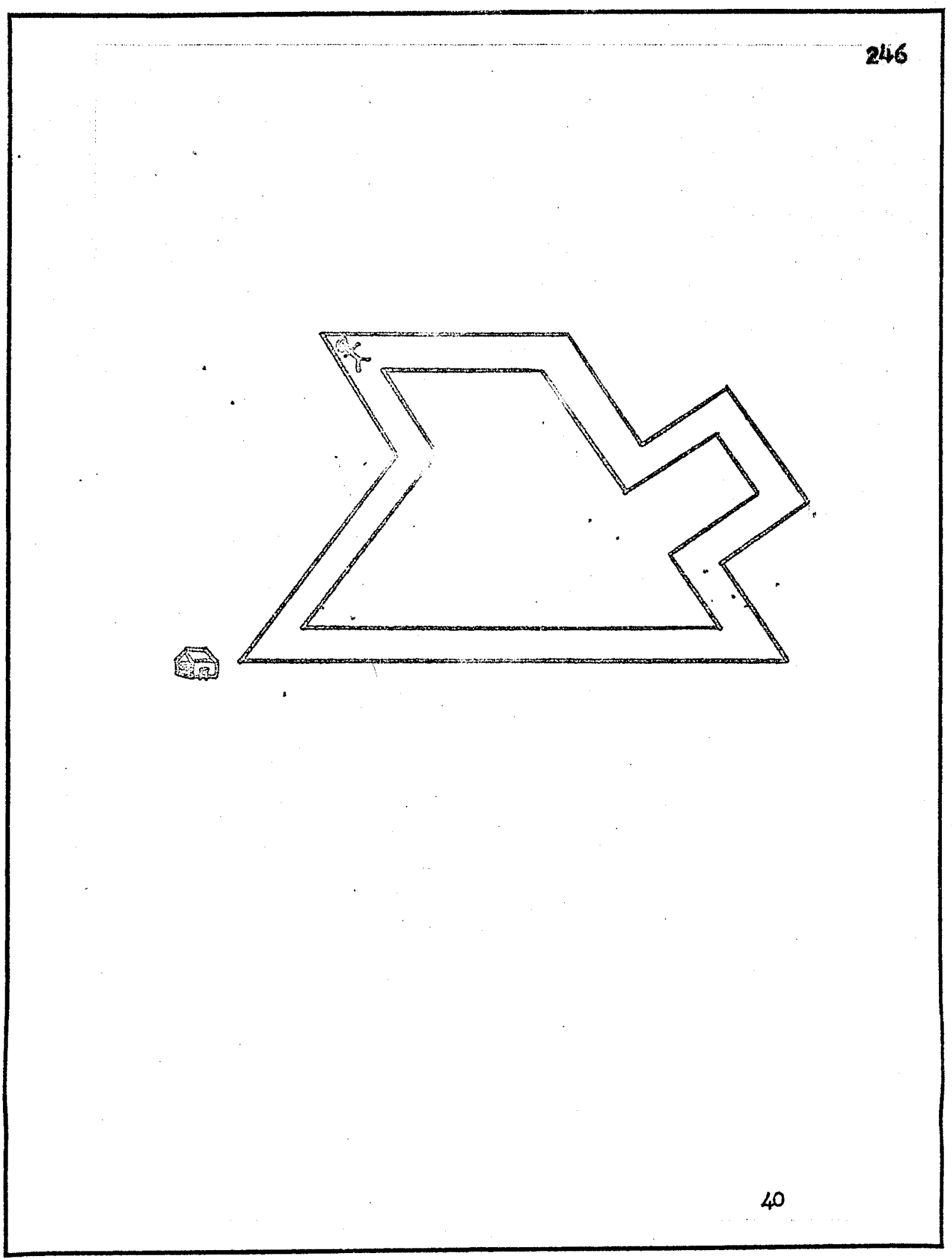




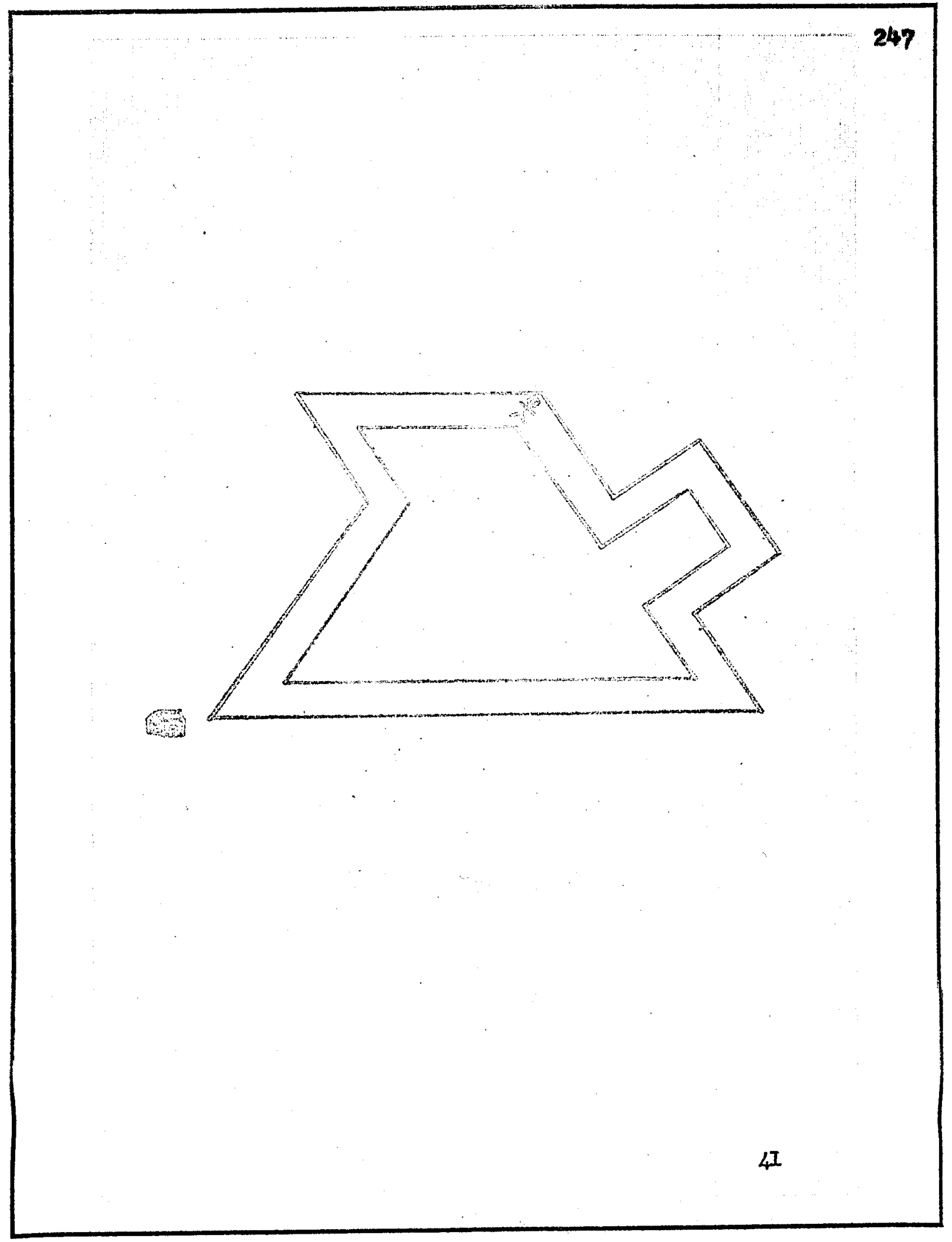




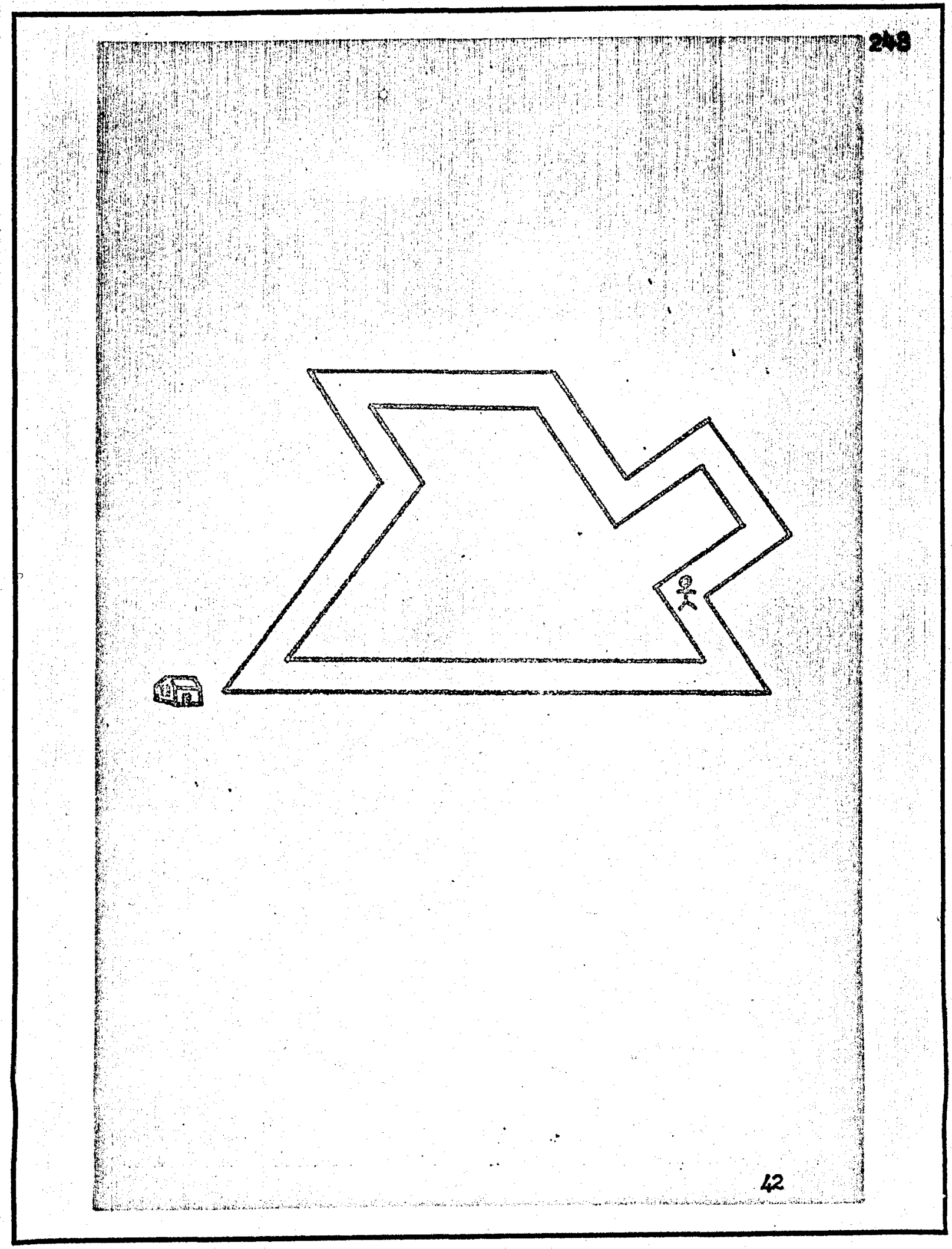




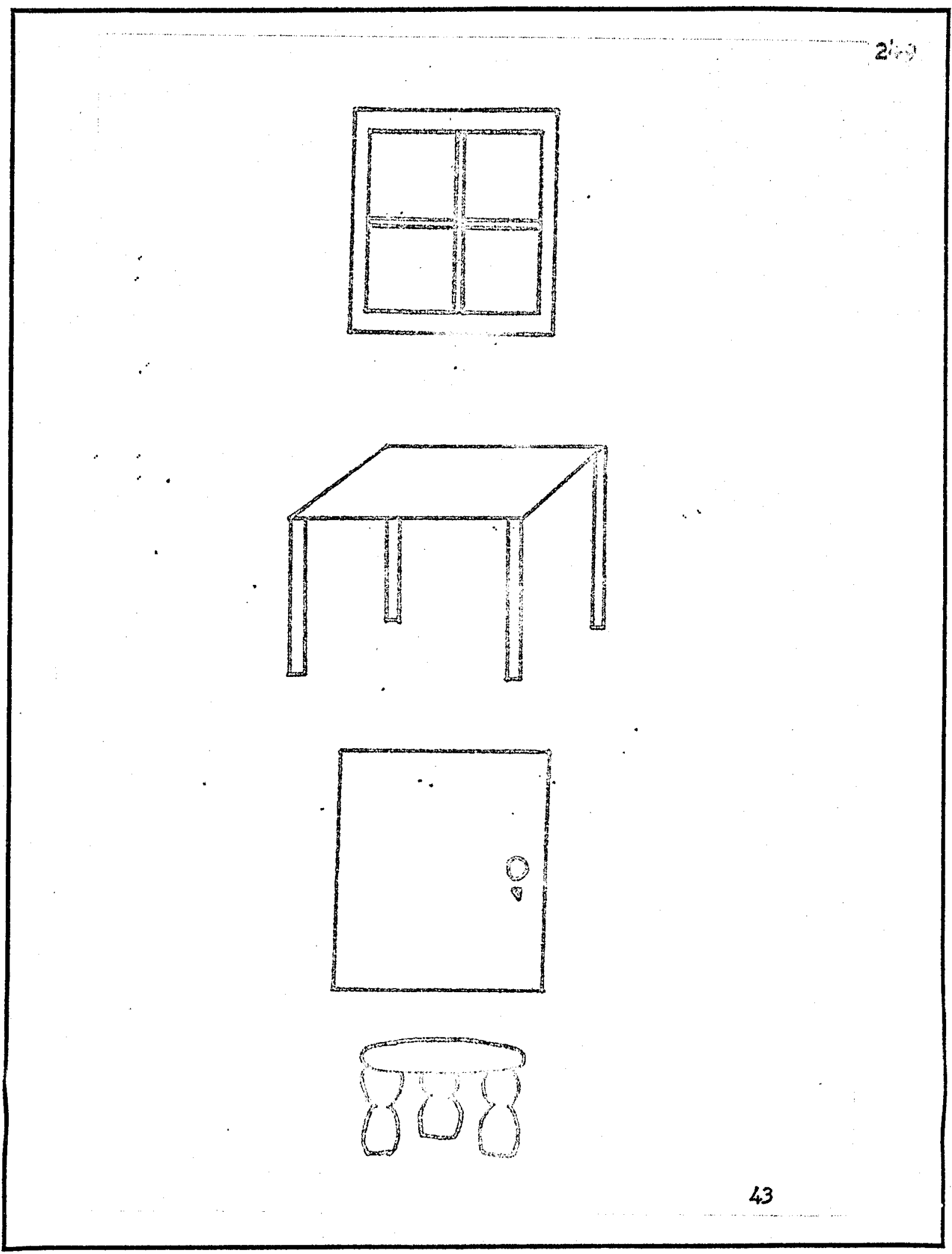




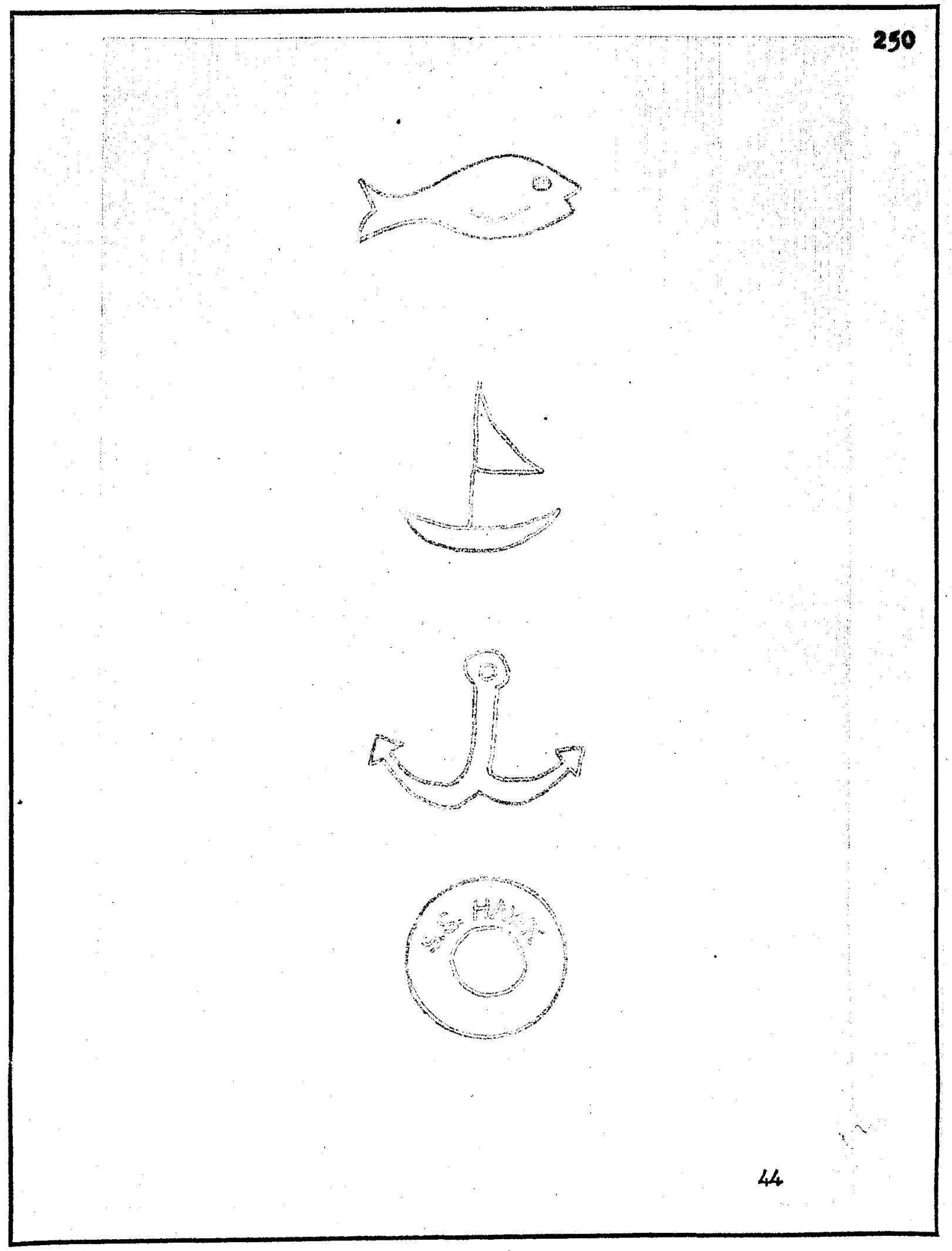




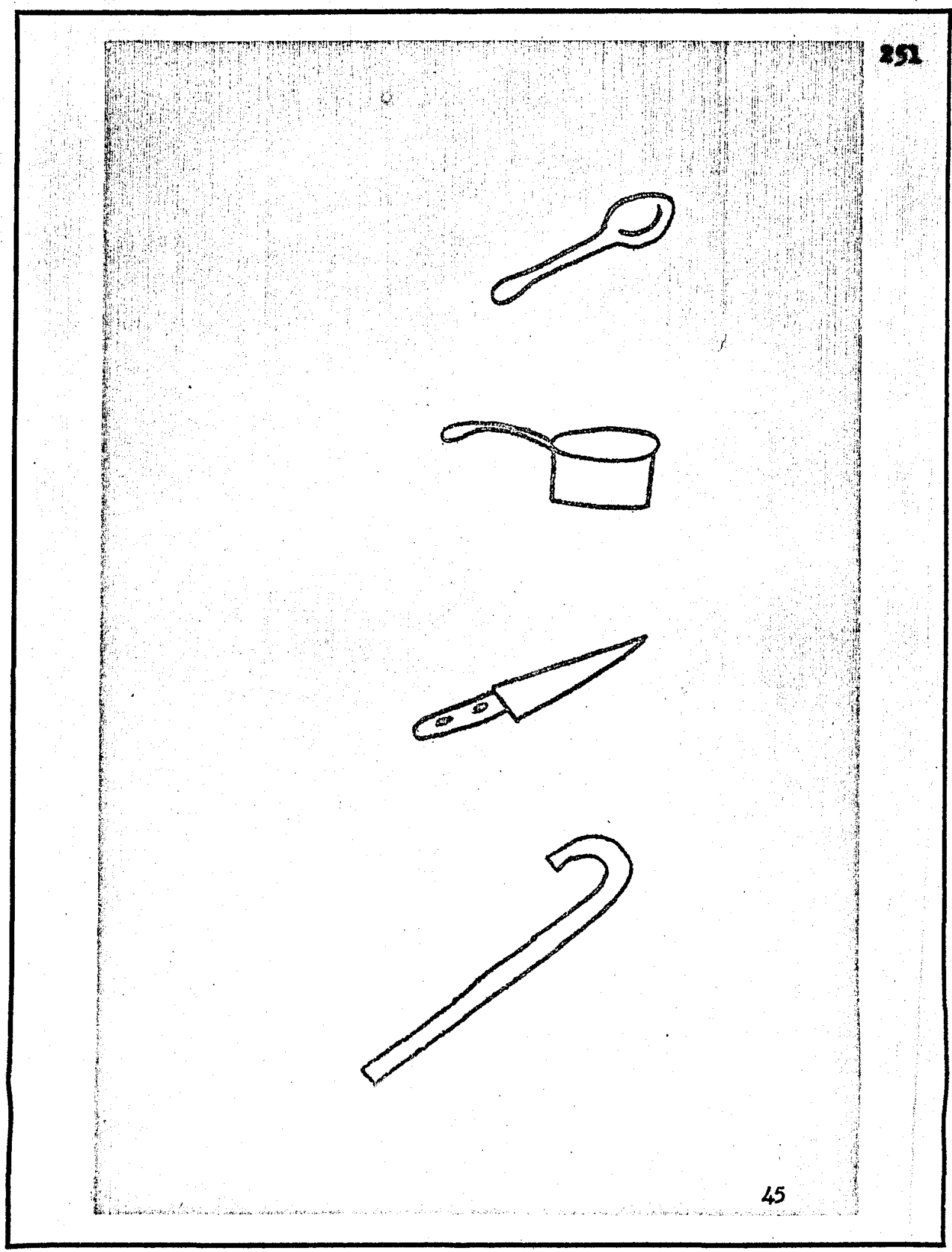




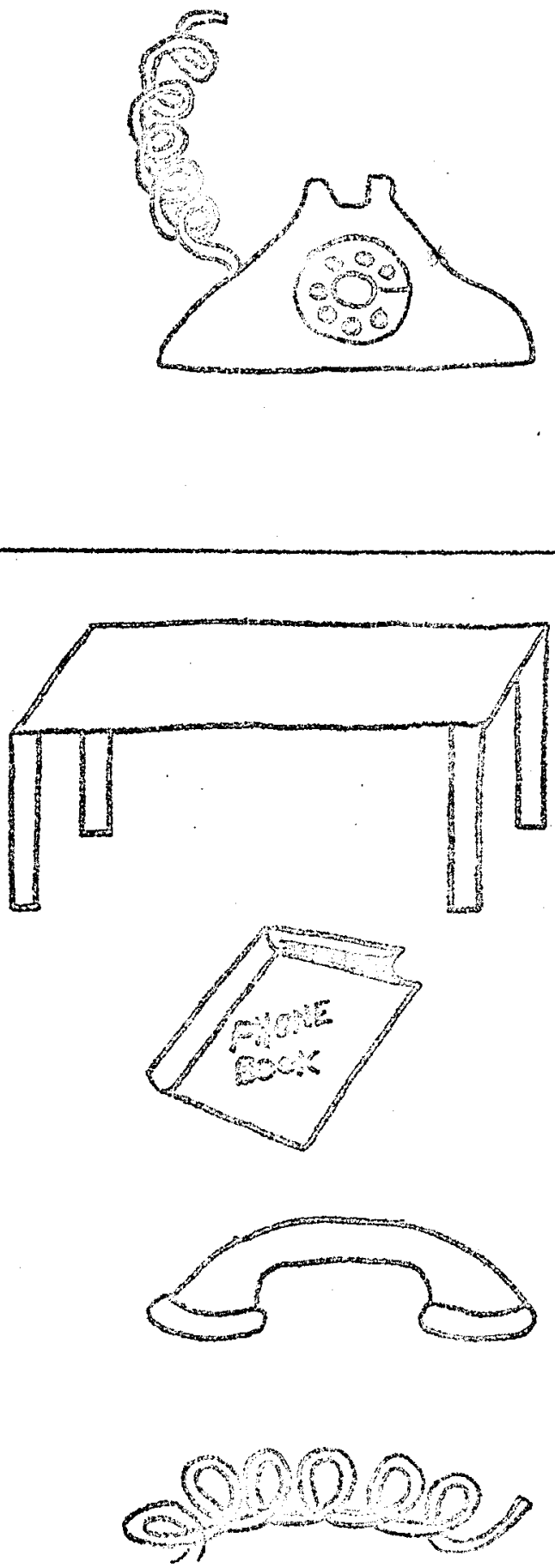


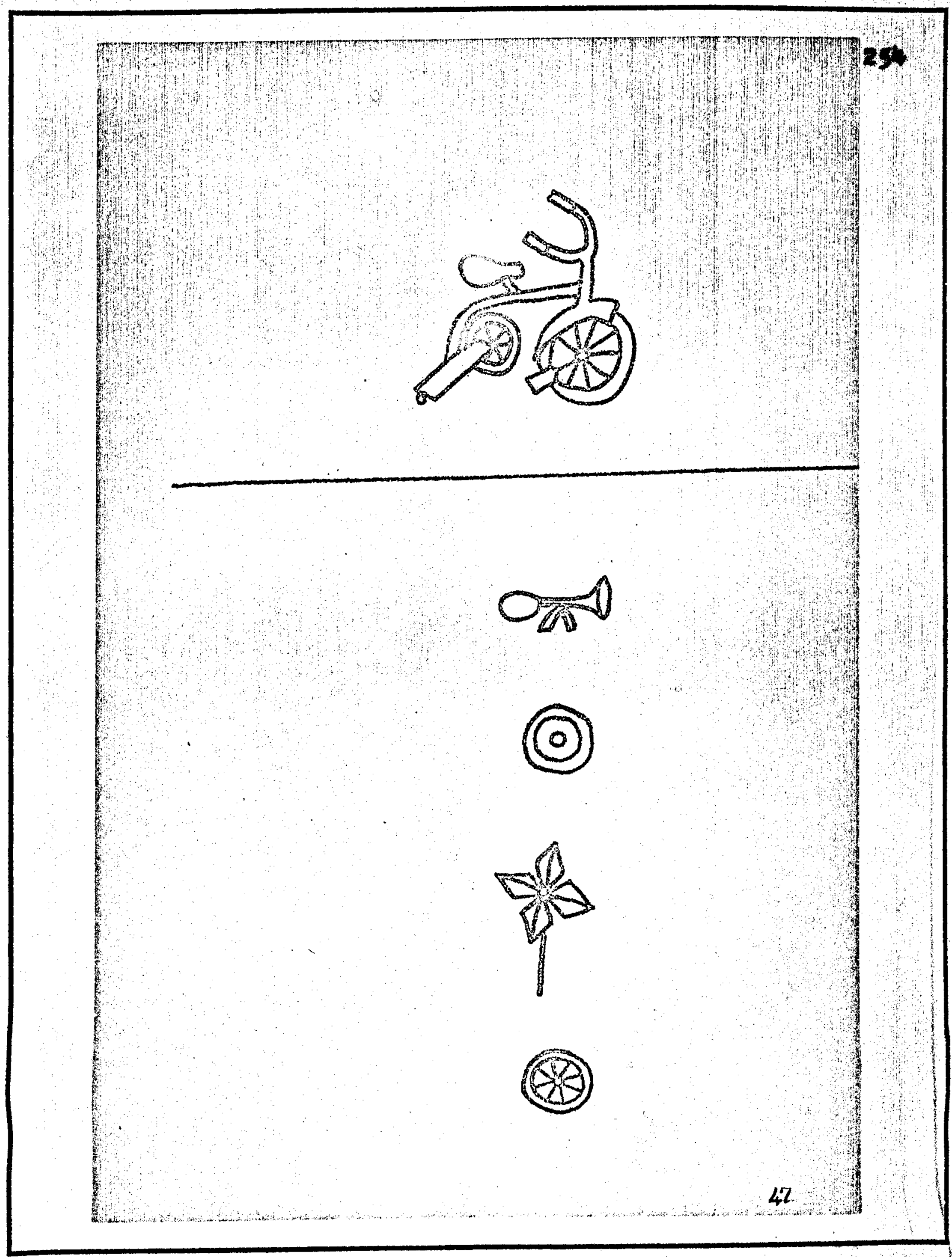




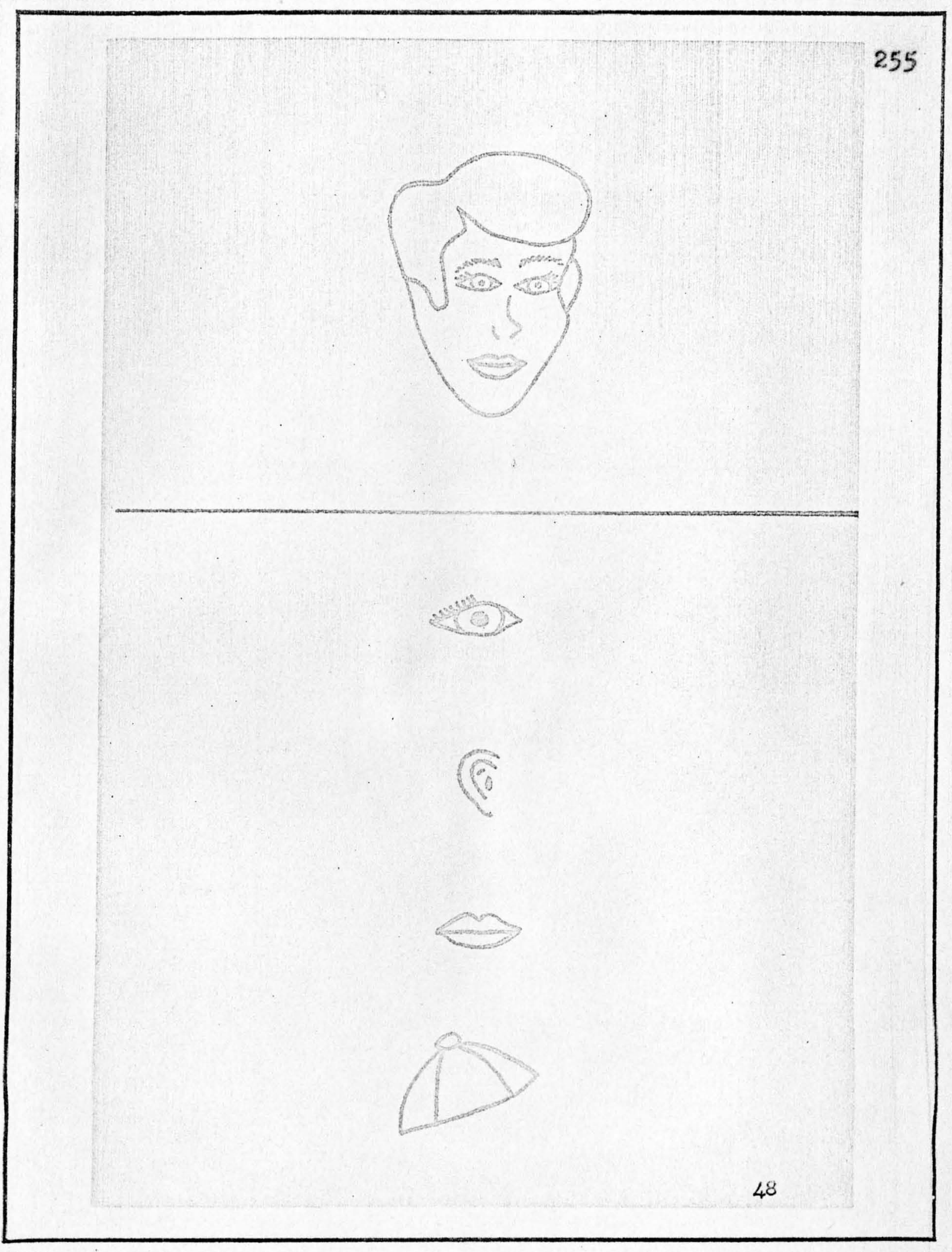




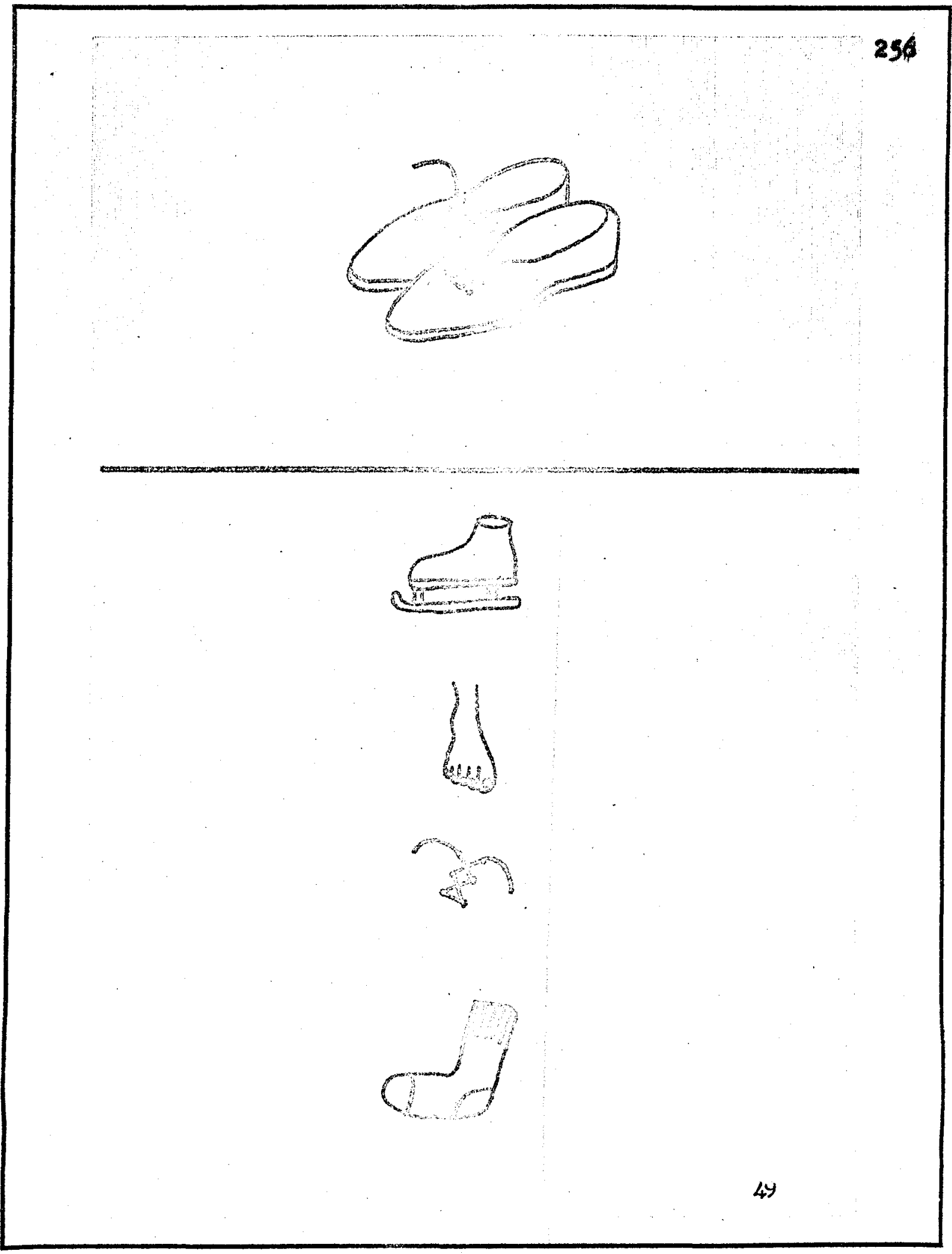




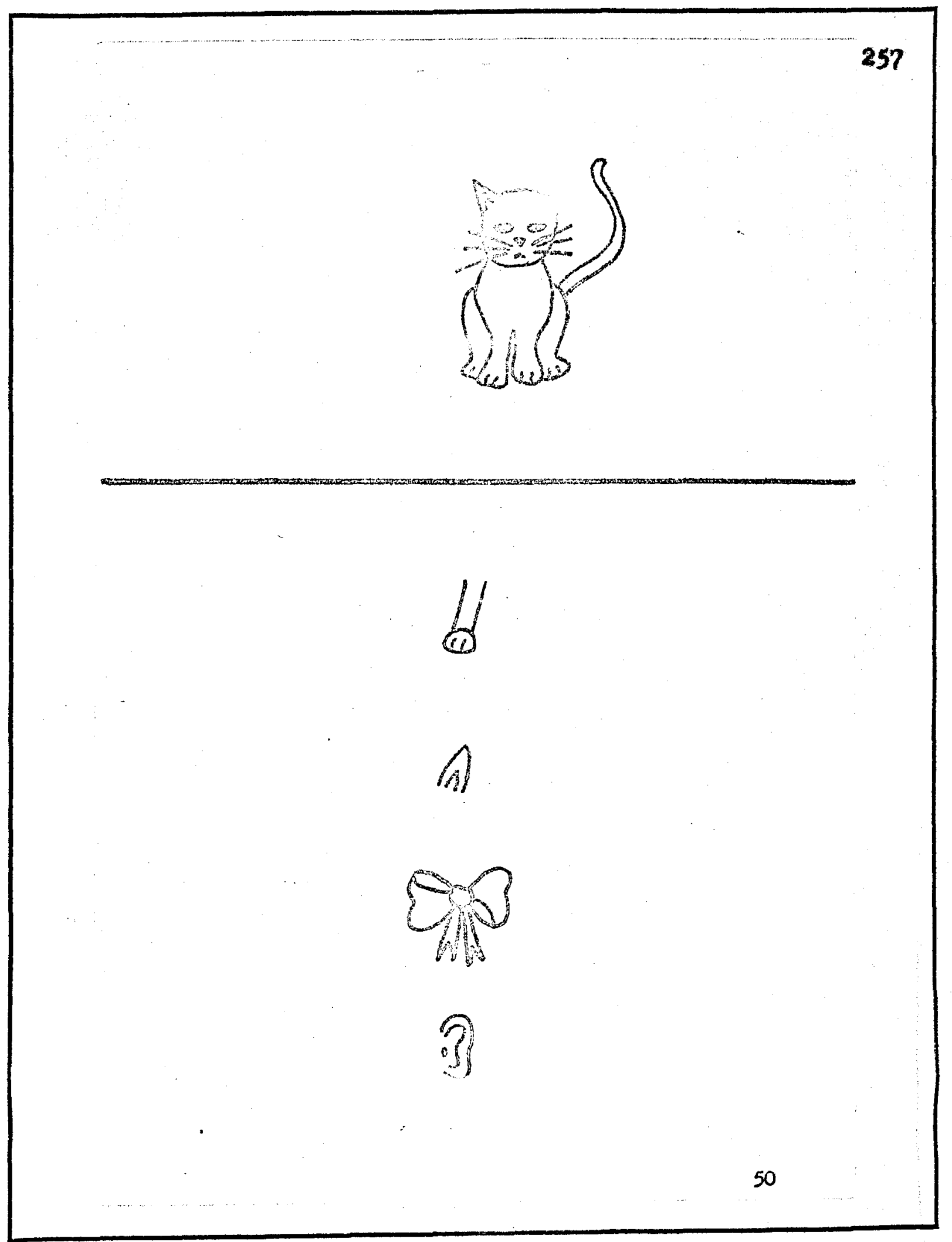




\section{APPENDIX $C$}

PRESCHOOL GROUP SCFEENING TEST RECORD FORA

Neme

Test No. Sex

Total Soore

Deviation IQ

(Soore 0 or 1 point for each 1 tem. Total Possible soore = 81 points)

1. orange

2. envelope

3. otran

4. Aman

-5. puddle

6. som

7. Ilon

8. ejelashes

9. Jugszer

10. resoue

11. manst on

1-11. ( 7 to $9+1$

$1-11$. $(10+)$

12. longest

13. 6

14. shortest

15. 5

16. thind

17. $\mathrm{s}$

18. $\mathrm{B}$

19. A

20. 0

$17-20 .(3+)$

21. mouse

22. blaok

23. do8

24. b1 Ird $\begin{aligned} & 21-24 .(3+) \\ &- 25.936 \\ &- 26.01 \text { role } \\ &- 27 . \text { triangle } \\ &- 28 . \text { square } \\ &-26.28 .(2+)\end{aligned}$

29. A. head

29. B. mouth

29. C. nose

29. D. eyes

29. E. eje detall

29. F. halr

29. G. cars

29. H. 1egs

29. I. arms

29. J. trunk

29. K. length of trunk

29. I. neok

29. M. ringer

29. N. number of fingers

29. A-r. (7 to $9+1)$

29. 1-N. (10t)

30. three

31. ten

32. $81 x$

33. nine

34. seven
$30-34 .(4+)$

35. diamonds

36. 3 lettere

36. I r ret name

36. complete name

36. complete name

36. complete name

37.3

38. 9

$37-38 .(2+)$

39. 3 errore

39. no errors

39. no errors

40. naze

41. naze

42. maze

40-42. $(2+)$

43. Mindow

44. I1sh

45. $\mathrm{kmife}$

$23-45 .(3+)$

46. reoelver

47. triejole wheal

48. person's ear

49. shoe 1ace

50. kitten's eax 46-50. (4t) 


\section{APPBOVAL SHEET}

The d1ssertation submitted by August Bdward Ahr has been read and approved by a board of five nombers of the Department of Eduoetion.

The flnal coples have been examined by the direotor of the dissertation and the slgnature whioh appears below rerifles the fact that any necessary ohanges have been Incorporated, and that the disgertation is nor given final approval with reference to content, form, and meohanioal acouracy.

The dissertation is therefore acoepted in partial fulf1Ilment of the requirements for the Degree of Doctor or Education.

$O$

260,1966 Date
Sonnuel Mayo signature of Karisqy(PK) 